UNIVERSIDADE DE SÃO PAULO

FACULDADE DE FILOSOFIA, LETRAS E CIÊNCIAS HUMANAS

DEPARTAMENTO DE FILOSOFIA

PROGRAMA DE PÓS-GRADUAÇÃO EM FILOSOFIA

Mariana de Mattos Rubiano

Revolução em Hannah Arendt: compreensão e história

(versão corrigida)

São Paulo

2016 
Mariana de Mattos Rubiano

\section{Revolução em Hannah Arendt: compreensão e história}

Tese apresentada ao Departamento de Filosofia da Faculdade de Filosofia, Letras e Ciências Humanas da Universidade de São Paulo para obtenção de título de Doutora em Filosofia, sob a orientação do Prof. Dr. Alberto Ribeiro Gonçalves de Barros.

(versão corrigida após defesa)

O Prof. Dr. Alberto Ribeiro Gonçalves de Barros está de acordo com esta versão.

São Paulo

2016 


\section{FOLHA DE APROVAÇÃO}

RUBIANO, M. Revolução em Hannah Arendt: compreensão e história, 2016. Tese (Doutorado). Faculdade de Filosofia, Letras e Ciências Humanas. Faculdade de Filosofia, Universidade de São Paulo, São Paulo, 2016.

Banca examinadora:

Professor(a) $\operatorname{Dr}(a)$

Instituição:

Julgamento:

Assinatura:

Professor(a) $\operatorname{Dr}(a)$.

Instituição:

Julgamento:

Assinatura:

Professor(a) $\operatorname{Dr}(a)$.

Instituição:

Julgamento:

Assinatura:

Professor(a) Dr(a).

Instituição:

Julgamento:

Assinatura:

Professor(a) $\operatorname{Dr}(a)$.

Instituição:

Julgamento:

Assinatura: 
Dedico esta tese a Christian e a meus pais, Márcia e Pedro 


\section{Agradecimentos}

Esta tese não teria sido possível sem o incentivo e a interlocução das professoras e dos professores que foram fundamentais para minha formação. Por isso, agradeço, especialmente, ao Alberto Ribeiro Gonçalves de Barros, por seu inestimável papel como orientador, pela leitura atenta, rigorosa e generosa de meus textos. Sou grata ao Edson de Almeida Teles, à Maria das Graças de Souza, à Patrícia Fontoura Aranovich e ao Adriano Correia, pela disposição e entusiasmo em debater sobre filosofia e política. Ao professor Andreas Kalyvas, que gentilmente me recebeu na New School For Social Research, pelo estímulo e pelas importantes contribuições. Agradeço aos meus professores de graduação Gildo Marçal Brandão (em memória) e Maria Célia Paoli, que despertaram em mim o gosto pela pesquisa sobre o pensamento político.

Sou ainda devedora dos pesquisadores da pós-graduação que me mostraram que o estudo envolve comunidade e compartilhamento de ideias. Particularmente, sou grata ao Thiago Dias e ao Moisés Spellmeier, por terem enfrentado comigo as inquietações que provocam a leitura dos textos de Arendt logo no início do mestrado. Agradeço aos amigos do grupo Res Publica, pela valorosa contribuição nos estudos e pelos banquetes; aos amigos dos Cadernos de Ética e Filosofia Política, pelo aprendizado e pelos momentos de descontração; aos colegas do Encontro Arendt e do GT de Filosofia Política Contemporânea, pelos profícuos debates e leituras.

Sou grata também às funcionárias do Departamento de Filosofia pelo suporte técnico e por me ajudarem a superar as questões burocráticas.

Agradeço ao Christian pelo companheirismo, pelos debates acadêmicos e políticos e pela paciência na revisão deste texto. Às amigas da vida inteira Paula, Ana Alice, Patrícia e Marina. Aos amigos Fábio, Adne e Alexandre. A Sonia e Rudi pelo apoio. À minha família, em especial aos meus pais, à minha avó Maisé, ao meu irmão e à Amanda, pelo carinho e apoio.

Por fim, sou grata à FAPESP pelo fomento à minha pesquisa de doutorado no Brasil e pela bolsa de estágio de pesquisa no exterior. 


\section{Resumo}

Esta tese tem como principal objetivo discutir o livro Sobre a Revolução de Hannah Arendt. Levando em conta que este livro foi menos discutido pelos comentadores do que Origens do Totalitarismo, Condição Humana e Eichmann em Jerusalém, nossa pesquisa busca contribuir com a literatura sobre o pensamento arendtiano. Além disso, também visamos a contribuir com os debates de filosofia política ao tratar dos conceitos centrais apresentados em Sobre a Revolução tais como liberdade, ação, poder, fundação, resistência, soberania, dominação, governo, representação, entre outros.

Mostraremos que as concepções de revolução e política no pensamento de Arendt são formuladas em contraposição à tradição e às teorias mais influentes de seu tempo: o marxismo e o liberalismo. Para ela, as categorias tradicionais não são capazes de explicar as novidades que as revoluções trouxeram. O marxismo favorece o debate sobre as questões sociais em detrimento das questões políticas e não leva em conta a Revolução Norte-Americana. Já o liberalismo trata principalmente das atividades privadas e do bemestar individual e, com isso, desvaloriza a atividade pública e as experiências revolucionárias.

Nesse sentido, Sobre a Revolução nasceu de um esforço de valorizar os aspectos políticos da revolução e criticar as teorias hegemônicas da década de 1960. Pensamos que o viés crítico deste livro não perdeu sua força: Arendt, diferentemente da historiografia e do pensamento político que surgiram a partir da década de 1980, não afirma que a experiência revolucionária francesa foi um completo fracasso nem considera que a principal novidade da Revolução Norte-Americana foi estabelecer um governo representativo liberal. Ela discute tanto os grandes feitos e ideias quanto os equívocos das Revoluções no Novo e no Velho Mundo.

Levando isso em conta, esta tese discutirá os conceitos políticos de Arendt, apresentará seu debate com o pensamento político e indicará sua crítica ao mundo contemporâneo. Nossa hipótese consiste em que Sobre a Revolução pode ser interpretado como uma narrativa da história dos conceitos. Buscaremos sustentar que neste livro a história conceitual indica a distinção entre as concepções antigas, tradicionais e revolucionárias; revela o pathos de novidade das revoluções; permite formular as narrativas das Revoluções Norte-Americana e Francesa por meio das concepções dos revolucionários; trata da distorção de significado de alguns conceitos produzida pelas teorias no século XX e recupera as concepções e experiências esquecidas, que são capazes de auxiliar na compreensão do presente.

Palavras-chave: Revolução, Liberdade, Fundação, Compreensão, História dos Conceitos. 


\section{Abstract}

This thesis aims at discussing primarily the book On Revolution by Hannah Arendt. Considering that this book has been less debated than Origins of Totalitarianism, The Human Condition and Eichmann in Jerusalem by the commentators, my research seeks to add to the Arendtian's thought literature. Moreover, it also aims at contributing with the debates of political philosophy by dealing with the main concepts introduced in $O n$ Revolution, such as freedom, action, power, foundation, resistance, sovereign, rule, government, representation, among others.

I will demonstrate that in Arendt's thought the concepts of revolution and of politics are formulated against the tradition and against the most influential theories of her time: the Marxism and the Liberalism. According to her, the traditional categories are not able to explain the novelties brought by revolutions. The Marxism supports the debate on social question over the political matters and it does not take into account the North-American Revolution. In turn, Liberalism mainly deals with the private activities and individual welfare thereby it devaluates the public activities and the revolutionaries experiences.

In this sense, On Revolution came from an effort to valorize the political aspects of revolutions and to criticize the hegemonic theories in the 1960s. I hold that the critic bias of this book has not lost its strength: differently from historiography and political thought which have arose since 1980, Arendt does not assert that the French revolutionary experience was a complete failure nor consider the settlement of liberal representative government as the most important novelty of North-American Revolution. She discusses both the great acts and ideas and the misconception in the revolutions of the New and Old World.

Taking it into account, this thesis will discuss the Arendtian political concepts, it will introduce Arendt debate with political thought and it will indicate her critic about the contemporary world. My hypothesis is that On Revolution can be interpreted as a narrative on history of concepts. I seek to demonstrate that the conceptual history in this book points to the distinction between Ancient, traditional and revolutionaries conceptions; it discloses the pathos of novelty which was brought by the revolutions; it allows to formulate through the conceptions of revolutionaries the stories on North-American and French Revolutions; it deals with some misleading concepts created by twentieth century's theories; and it recovers forgotten concepts and experiences able to aid in the task of understanding the present.

Key-words: Revolution, Freedom, Foundation, Understanding, Conceptual History. 


\section{Sumário}

Introdução

Apresentação e justificativa da tese 10

As leituras de Sobre a Revolução

Revisão histórica das revoluções

Revisão teórica das revoluções 36

Capítulo 1: Compreender a Revolução $\quad 41$

1.1 Dilema do século XX 43

1.2 Ruptura com a tradição e formulação de novos conceitos

1.3 A história do conceito de revolução 60

$\begin{array}{ll}1.4 \text { Liberdade e revolução } & 67\end{array}$

$\begin{array}{ll}1.5 \text { Liberdade na tradição filosófica } & 78\end{array}$

1.6 Liberdade e novo início 84

1.7 As interpretações das revoluções no século XIX 89

1.8 Filosofia da história e revolução 99

1.9 Conceito moderno de história e revolução: algumas conclusões. 110

$\begin{array}{ll}\text { Capítulo 2: As narrativas das Revoluções } & 116\end{array}$

2.1 Origens das revoluções: crise da autoridade, resistência e gosto pela liberdade 118

2.2 Os Pais Fundadores 141

2.3 Líderes da Revolução Francesa 158

2.4 As Declarações na Revolução Norte-Americana e na Revolução Francesa. 177

2.5 História dos conceitos e as narrativas das revoluções em Arendt 183

Capítulo 3: 0 tesouro perdido das Revoluções $\quad 189$

$\begin{array}{ll}3.1 \text { Fundação } & 191\end{array}$

3.2 Constituição 207

3.3 A fundação do novo: os conselhos revolucionários 216

3.4 Conflito entre o sistema de partidos e o sistema de conselhos e a história do conceito de

governo. 230

3.5 Mudança no significado de representação $\quad 245$

3.6 História dos conceitos e o tesouro perdido das revoluções: algumas considerações 256

$\begin{array}{ll}\text { Considerações finais } & 263\end{array}$ 
Bibliografia

275

1. Bibliografia principal 275

2. Bibliografia de comentadores

276

3. Bibliografia de apoio

278 


\section{Introdução}

\section{Apresentação e justificativa da tese}

O objetivo deste trabalho de doutorado consiste em discutir o livro Sobre a Revolução de Hannah Arendt. Especificamente, trataremos da interpretação da autora sobre as revoluções. A pertinência deste trabalho se justifica em dois aspectos: primeiro, este livro trata dos principais conceitos políticos arendtianos ao discutir as potencialidades e problemas da ação política na Modernidade; e, segundo, o livro Sobre a Revolução, apesar de mobilizar temas políticos de primeira importância, foi considerado por alguns comentadores como secundário ou mesmo pouco relevante no pensamento de Arendt.

Para falar de maneira resumida, Origens do Totalitarismo, A Condição Humana e Entre o Passado e o Futuro tratam dos obstáculos para a política desde o início da Modernidade. O primeiro livro discute o nazismo e o stalinismo, procura apontar os elementos que contribuíram para o surgimento destes regimes, tais como o antissemitismo, o imperialismo e o surgimento das massas com a desintegração da sociedade de classes. Além disso, ele mostra a forma de funcionamento dos regimes totalitários. De acordo com Arendt, o nazismo e o stalinismo visaram à dominação total: o controle das atividades 
privadas como trabalho, educação e comunicação. E também tinham a pretensão de controlar as mentes por meio da doutrinação. Para tanto, era preciso que as pessoas estivessem no espaço público onde a propaganda e a ideologia eram propagadas, onde as pessoas cooptadas para o movimento eram vigiadas. Nesse contexto, o espaço público perdeu sua dimensão política: deixou de ser o lugar da ação, de troca de opiniões plurais e de deliberação pública, para se tornar o lugar de controle do comportamento, de divulgação de ideologia totalitária, que propaga que todos devem seguir as ordens do líder.

Já em A Condição Humana, Arendt define inicialmente as três atividades humanas (trabalho, fabricação ou obra e ação) com base no pensamento de Aristóteles e sua distinção entre os modos de vida do escravo, do artesão e do cidadão. Por meio da referência à Antiguidade, a autora trata das características, dos lugares e relevância de cada atividade: o trabalho é encarregado pela reprodução da vida, consiste no processo de produzir e consumir para que a sobrevivência seja garantida. Originalmente era realizado somente no espaço privado e era a atividade menos valorizada, destinada em grande parte aos escravos. A obra ou fabricação está ligada ao artifício, à capacidade do homem de criar um mundo próprio, diferente do ambiente natural; consiste em fabricar coisas duráveis e instrumentos, por isso, é baseada na categoria de meios e fins. Na Antiguidade, a fabricação era realizada no espaço privado, mas muitos de seus produtos podiam ser destinados ao espaço público. Já a ação consiste na atividade política: diz respeito à relação entre os homens sem levar em conta as necessidades e impulsos naturais; é a atividade que permite que os homens formem uma comunidade, debatam e decidam sobre assuntos comuns. Era a atividade mais valorizada na Antiguidade e seu lugar era o espaço público a ágora. Arendt, no último capítulo do livro, mostra que alguns eventos levaram a uma inversão dentro da hierarquia das atividades humanas na Modernidade: desvalorizaram a ação e promoveram a fabricação e o trabalho. A autora discute as dificuldades para a atividade política em nosso tempo e o crescimento do trabalho em dois sentidos, a saber, de sua produtividade e do consumo.

Por fim, em Entre o Passado e o Futuro, a autora, no primeiro ensaio do livro, trata da crise e da perda da tradição, a qual conduziu a uma dificuldade em lidar com o passado e com o presente. As teorias, categorias, formas de análise e costumes transmitidos pela tradição deixaram de auxiliar o pensamento sobre o presente e perderam a capacidade de 
guiar as ações dos homens. Arendt, em outros dois artigos do livro, discute dois conceitos políticos que são mal compreendidos em seu tempo, a saber, autoridade e liberdade. Ela indica como estes conceitos foram definidos pela tradição filosófica e busca uma nova definição, mais adequada para pensar o mundo contemporâneo. A crise da tradição também é tratada no segundo artigo do livro, a propósito do abandono do conceito antigo de história. Com a formulação de um novo conceito na Modernidade, a história passa a ser definida de duas maneiras: ou como um encadeamento de fatos causais ou como um processo que revela uma tendência ou um telos. Este conceito moderno de história surgiu para tentar substituir a tradição ao oferecer um fio condutor para o passado e amparos para a compreensão do presente. Contudo, na perspectiva da autora, ele mais obscurece do que esclarece os feitos e eventos políticos modernos. Além disso, em Entre o Passado e o Futuro, Arendt aborda a crise na cultura e na educação. A ruptura com a tradição dificultou a relação das pessoas com os artefatos culturais do mundo: elas não sabem ao certo quais coisas devem cuidar e preservar e não sabem como apresentar o mundo às crianças para que no futuro elas possam agir nele.

Pode-se notar que, de maneira geral, estas três obras tratam das dificuldades da política na Modernidade em dois registros: para a compreensão dos eventos políticos e para a ação. Em Sobre a Revolução, Arendt também trata dos desafios da compreensão e da política na Modernidade, mostra que as categorias tradicionais não conseguem explicar completamente os eventos revolucionários e indica que a ação revolucionária pode fracassar, ou seja, pode não conseguir instituir um corpo político duradouro. Mas distintamente dos outros livros, nesta obra, ela reflete sobre os eventos modernos em que a ação foi entendida como a principal atividade humana ${ }^{1}$ e elabora uma narrativa das Revoluções Americana e Francesa sem recorrer às categorias de causalidade e de tendência histórica. Nesse sentido, sua reflexão sobre as revoluções revela tanto os riscos como as potencialidades da ação na Modernidade. Nossa investigação será centrada nesta obra. Nela a autora discute a atividade política a partir do século XVIII e analisa como os eventos revolucionários ressignificaram os principais conceitos políticos, tais como:

\footnotetext{
${ }^{1}$ Adriano Correia mostra esta peculiaridade de Sobre a Revolução ao indicar que a felicidade experimentada pelos revolucionários, ao participarem dos assuntos públicos, consiste em um contraponto à valorização e aumento da atividade do trabalho na Era Moderna e à felicidade do animal laborans, alcançada por meio da satisfação obtida com o consumo exacerbado. Ver em Hannah Arendt e a Modernidade, p. XXX.
} 
fundação, constituição, autoridade, liberdade, lei, direito, governo, representação, entre outros.

Nesta perspectiva, a tese procurará contribuir para o estudo tanto do pensamento de Arendt quanto da área de ética e filosofia política. No que concerne aos estudos da área de ética e filosofia política, visaremos a indicar como Arendt trata os autores da tradição filosófica e apontaremos a singularidade dos conceitos e da forma de análise desta autora. Para tanto, a tese terá como objetivo principal esclarecer os conceitos mobilizados em Sobre a Revolução. Ao tratar do conteúdo dos conceitos, fatalmente, deparamo-nos com a investigação dos procedimentos e do modo de reflexão mobilizados para sua formulação. O conjunto de procedimentos em que a autora se apoia para analisar as revoluções implica uma maneira particular de cunhar conceitos e de relacioná-los; além disso, engendra uma concepção de história, uma forma particular de lidar com o passado e uma maneira de dialogar com pensadores precedentes e contemporâneos. Tais procedimentos serão analisados de forma secundária e na medida em que esclarecem os conceitos e conclusões formulados pela autora.

Com relação ao estudo sobre o pensamento arendtiano, a tese visa a reforçar a perspectiva de que Arendt não é nostálgica do passado greco-romano, embora recorra diversas vezes à Antiguidade para buscar a origem dos conceitos. Procuraremos mostrar que seu pensamento é marcado fortemente pelos eventos modernos e contemporâneos, particularmente, o surgimento das revoluções e dos regimes totalitários. ${ }^{2}$

No livro Sobre a Revolução, notamos que os principais conceitos políticos sofrem deslocamentos. Em outras palavras, com o surgimento dos eventos revolucionários, as categorias encontraram um ponto de inflexão: elas se modificaram, ganharam novos significados.

Diversos comentadores já demonstraram que um dos recursos analíticos mais mobilizados por Arendt consiste na busca da origem do conceito, isto é, na busca do fenômeno que fez surgir pela primeira vez uma palavra que, a partir de então, passa a carregar o sentido deste fenômeno. ${ }^{3}$ A autora, em Sobre a Revolução, para discutir os

\footnotetext{
${ }^{2}$ Entre os principais autores que a consideram nostálgica estão Lebrun, em Passeios ao Léu, e O’Sullivan em "Hannah Arendt: a nostalgia helênica e a sociedade industrial".

${ }^{3}$ Este procedimento é denominado de maneira distinta de acordo com o comentador: para Adriano Correia, trata-se de uma fenomenologia genealógica (Hannah Arendt e a Modernidade, p. XXII); Young-Bruel chama
} 
conceitos políticos, em primeiro lugar, volta à Grécia Antiga e à Roma republicana para recuperar o significado original de termos políticos e, num segundo momento, indica a historicidade deste conceito a partir da Modernidade. O exemplo mais importante deste procedimento está na análise da palavra revolução: sua origem ou genealogia é indicada quando o termo, além de designar um movimento astronômico, passa a designar também um fenômeno político, a saber, a restauração de antigos regimes políticos. Após identificar a origem, a autora mostra sua historicidade: o termo revolução, no século XVIII, deixa de significar restauração para indicar a fundação de um novo corpo político sem precedentes na história. Já no século seguinte, o termo vai do campo político para o histórico - quando começa a indicar o momento de aceleração da mudança social conforme uma tendência ou telos histórico identificável.

Os acontecimentos na América do Norte em 1776 e na França em 1789 não só ressignificaram o termo revolução, como indicaram também que as relações e tensões entre alguns conceitos foram alteradas. Por exemplo, as revoluções entendidas como fundação de um novo corpo político ou como transformação radical da sociedade deslocaram a violência - que desde a Antiguidade estava relacionada com a guerra entre cidades - para dentro da comunidade. A partir das revoluções do século XVIII, a violência passou a ser um meio para libertar as pessoas de um governo opressor. Isso ampliou as possibilidades de libertação da dominação, mas também gerou novos riscos para a ação: que o espaço público possa ser dominado pela perseguição e pelo terror.

Levando isto em conta, este trabalho apontará o impacto que as revoluções têm no pensamento de Arendt. Em outras palavras, será discutido como os eventos revolucionários levaram a autora a repensar categorias tradicionais e a cunhar seus próprios conceitos por meio da origem dos termos e de sua historicidade. Para dizer de forma resumida, a tese apresentará uma interpretação de Sobre a Revolução na qual este livro é lido como uma narrativa da história dos conceitos políticos. A tese deverá explorar os deslocamentos que os conceitos sofreram da Antiguidade até a contemporaneidade, e discutir como estes deslocamentos geraram novas relações e tensões entre os conceitos.

de filologia ou análise linguística (Hannah Arendt: por amor ao mundo, p 286); segundo Benhabib, Arendt utiliza uma metodologia fenomenológica para recuperar o significado original dos termos (The Reluctant Modernism of Hannah Arendt, p.172); e André Duarte discute uma hermenêutica que reavalia a tradição e o passado (O Pensamento à Sombra da Ruptura , p. 130). 
Foi mencionado acima que o livro de Arendt dedicado às revoluções foi menos discutido se comparado a outros textos. Isso se deve ao argumento de que Sobre a Revolução seria um livro secundário no pensamento da autora. ${ }^{4}$ De maneira geral, este argumento é sustentado por três tipos de interpretações do pensamento arendtiano: o primeiro entende que a maior contribuição de Arendt está no campo da filosofia moral, de forma que alguns comentadores conferem mais importância aos livros Eichmann em Jerusalém, Responsabilidade e Julgamento e A Vida do Espírito, em detrimento dos escritos políticos.

O segundo tipo de interpretação entende que Sobre a Revolução consiste em uma espécie de continuação de $A$ Condição Humana. Ambos os livros discutem as dificuldades que a política passou a sofrer depois da emergência da esfera social. Nos eventos revolucionários, a ação teria sido desvirtuada quando o bem-estar social e individual se tornaram o principal assunto público. A leitura de Benhabib ilustra bem isso. Segundo esta autora, a insistência de Arendt em afirmar que os assuntos da esfera pública têm conteúdos próprios e que a necessidade não pode ser tema de debate público a levou a interpretar que as Revoluções Francesa e Russa falharam assim que surgiu na cena pública a questão social. ${ }^{5}$ Quando as massas famintas entraram em cena, conduziram estas revoluções ao terror.

De acordo com esta comentadora, Arendt separa política e economia por meio de uma divisão ontológica entre liberdade e necessidade. Embora em uma entrevista Arendt tenha admitido que alguns problemas - como moradia, educação, transporte e saúde - têm uma dupla face, isto é, dizem respeito tanto ao social quanto à política, ela insiste em que alguns conteúdos são distintivos e podem ser removidos da esfera pública e destinados à administração. ${ }^{6}$

\footnotetext{
${ }^{4}$ Conferir em Kalyvas, Democracy and the Politics of the Extraordinary, p. 187. De acordo com o autor, os escritos de Arendt sobre a revolução e os novos inícios têm sido negligenciados em favor de outros temas. Com relação aos comentadores brasileiros, Eduardo Jardim, por exemplo, afirma que as principais teses de Arendt são enunciadas em $A$ Condição Humana e $A$ Vida do Espirito. Ver em Hannah Arendt: pensadora da crise e de um novo início, p. 66.

${ }^{5}$ Conferir em The Reluctant Modernism of Hannah Arendt, p. 155.

${ }^{6}$ Ver em "Sobre Hannah Arendt".
} 
De acordo com Benhabib, a distinção entre o social e a política deveria ser traçada pelo critério de atitude: na esfera público-política, a perspectiva limitada e parcial é alargada por meio do debate e pode alcançar uma razão pública. Em outras palavras, para a comentadora, o que diferencia o social do político é a forma de abordar um tema. Em seu ponto de vista, Arendt, ao enfatizar o conteúdo em detrimento da forma para separar as questões políticas das sociais, acaba por entender que o aparecimento de problemas sociais na esfera pública corrompe a política. Dessa forma, a Revolução Francesa estava fatalmente fadada ao fracasso no momento em que as massas famintas surgiram no espaço público.

Se entendermos como correta a afirmação de Benhabib de que, para Arendt, o aparecimento da questão social na Revolução Francesa e sua ausência na Revolução Americana é o principal fator que explica o fracasso de uma e o sucesso da outra, então teríamos que concluir que Arendt contradiz sua tese de que a política não está necessariamente submetida ao econômico. Ocorre que, além da emergência da questão social, Arendt aponta fatores políticos que influenciaram o curso das duas revoluções. Benhabib pouco discute estes fatores. Por exemplo, o papel da concepção de soberania e vontade geral na Revolução Francesa não é intensamente trabalhado pela comentadora. Entendemos que os problemas enfrentados na França após 1791 não se relacionam, na obra de Arendt, somente com a questão social e a compaixão, mas também com a soberania e a vontade geral, que em boa medida definiram a forma com que a pobreza deveria ser abordada e o governo conduzido.

Além disso, a comentadora negligencia os problemas inerentes a todo novo início. Ao contrário, nesta tese discutiremos a imprevisibilidade dos novos inícios e do ato de fundar: não há garantias de que a ação fundadora seja bem sucedida, uma vez que a fundação envolve uma pluralidade de agentes e não consiste em ato que pode ser guiado por uma receita ou teoria. Nesse sentido, a imprevisibilidade inerente aos novos inícios é fundamental para compreender os riscos e potencialidades da ação na Modernidade.

Benhabib, ao colocar a questão social como central, interpreta Arendt como defensora da Revolução Americana e detratora da Revolução Francesa, e a coloca na 
mesma linhagem de Edmund Burke e Furet. ${ }^{7}$ Veremos adiante como Arendt está distante de Furet. Enquanto ela entende que a Revolução Francesa se desviou de seu curso inicial, para o historiador francês, esta revolução estava, desde o início, fadada ao fracasso: no livro organizado por ele e Ozouf, as sociedades e clubes populares aparecem como órgãos comprometidos com o domínio jacobino. Ao contrário, Arendt mostra como estes órgãos populares estavam em seu início engajados na ação política livre e plural, mas foram paulatinamente esvaziados e controlados após a ascensão de Robespierre.

$\mathrm{Na}$ leitura de Benhabib, Arendt enfatiza exageradamente a manipulação exercida pelos jacobinos nas sociedades populares, clubes e assembleias primárias em detrimento da ação do povo e, dessa forma, minimiza a atividade política experimentada nestes órgãos. ${ }^{8}$ Esta perspectiva, entretanto, parece estar em desacordo com o último capítulo da obra Sobre a Revolução, em que Arendt defende o sistema de conselhos, que na França se concretizou por meio da ação coordenada das sociedades, clubes e assembleias. Para ela, a experiência nos conselhos foi o tesouro perdido das revoluções. Nesse sentido, Benhabib parece ter focado mais no segundo capítulo da obra intitulado “A questão social”.

Outro comentador, André Duarte, também indica que Sobre a Revolução consiste em uma continuação das teses de $A$ Condição Humana em dois sentidos: segundo ele, nesta obra é reafirmada a tese arendtiana de que a política se tornou uma simples função da economia; e é retomado o mesmo procedimento usado em A Condição Humana, a saber, a avaliação os eventos modernos por meio do confronto com as concepções da Antiguidade.

Para Duarte, temas já tratados antes, como a distinção entre o político e o econômico, ação e administração são discutidos a propósito do desvio da liberdade para a necessidade ensejado durante a Revolução Francesa. ${ }^{9} \mathrm{O}$ argumento mais forte apresentado pela autora neste sentido seria de que as necessidades humanas não suportam a lentidão do processo de debate político, isto é, o caráter urgente da necessidade requer decisões imediatas. Nesta perspectiva, quando a ação revolucionária na França se comprometeu em resolver a questão social, ela se transformou fatalmente em ação instrumental violenta. Já a Revolução Americana não sofreu este desvio da liberdade para a necessidade, pois a

\footnotetext{
${ }^{7}$ Conferir em The Reluctant Modernism of Hannah Arendt, p. 157.

${ }^{8}$ Ver em The Reluctant Modernism of Hannah Arendt, p. 162-163.

${ }^{9}$ Conferir em O Pensamento à Sombra da Ruptura, p. 273-285.
} 
questão social estava ausente: a miséria e a escravidão não se tornaram temas do debate público. Isto possibilitou que os revolucionários se ativessem à questão de como estabelecer uma república. Nesta interpretação, o surgimento ou a ausência da questão social é central para explicar o sucesso ou o fracasso de uma revolução na medida em que a economia tem a tendência de se sobrepor à política.

Além disso, na visão de Duarte, outros conceitos já apresentados anteriormente, tais como ação, poder e promessa, apenas recebem sua comprovação com a experiência revolucionária. ${ }^{10}$ As revoluções confirmaram que a ação envolve ato e discurso, gera poder no espaço entre os homens e tem como condição a pluralidade humana. Por sua vez, a fundação - entendida como pacto mútuo que relaciona as pessoas e estabelece limites para a ação - retoma o conceito de promessa apresentado em A Condição Humana. Nesta leitura, o livro Sobre a Revolução não apresenta muitas novidades. Até mesmo o sistema de conselhos não é visto como inovação, mas como a redescoberta do princípio da participação política da Antiguidade. ${ }^{11}$

Para Duarte, as revoluções consistiram em repetição ou reatualização da origem da política. Nas palavras do comentador, “[...] Arendt não estava interessada na análise das revoluções como eventos históricos, mas em nos oferecer uma reflexão sobre a história fundada em sua ontologia política." (O pensamento à Sombra da Ruptura, p. 269). Em sua interpretação sobre a obra da autora, os revolucionários redescobriram as noções de liberdade, autoridade e fundação ao olhar para a Antiguidade e, nessa medida, suas ações nos conselhos revolucionários foram a encenação da política da polis grega e da república romana. $^{12}$

Em nossa perspectiva, a autora busca a genealogia dos conceitos, mas isso não significa que a origem aponta para a ontologia, uma vez que o conceito possui historicidade: seu significado mais recente pode ultrapassar sua origem. O sentido político de revolução, por exemplo, originalmente, indicava o movimento de retorno a uma constituição antiga e conhecida, mas com o surgimento das Revoluções Americana e Francesa passou a significar o início de um novo corpo político.

\footnotetext{
${ }^{10}$ Ver sobre conceito de poder em O Pensamento à Sombra da Ruptura, p. 294.

${ }^{11}$ Ver em $O$ Pensamento à Sombra da Ruptura, p. 306.

${ }^{12}$ O Pensamento à Sombra da Ruptura, p. 264.
} 
Como já foi mencionado anteriormente, nesta tese procuraremos apontar os deslocamentos que os conceitos políticos sofrem com as revoluções. Nesse sentido, os conceitos podem mudar completamente ou guardar conexão com sua origem. De qualquer forma, mesmo quando o núcleo conceitual não é completamente alterado, como no caso de liberdade, autoridade e fundação, isso não significa, contudo, que o grau de liberdade e as noções de autoridade e fundação que emergiram no século XVIII foram uma simples repetição da Antiguidade. Se fossem, Arendt não teria insistido no pathos de novidade das revoluções. Nesse sentido, os comentadores que submetem a análise de Sobre a Revolução às teses de $A$ Condição Humana acabam por obliterar algumas reflexões de Arendt.

Por fim, o terceiro tipo de interpretação considera que o livro Sobre a Revolução carece de rigor histórico e teórico e, por isso, não deve ser estudado profundamente. Hobsbawn, por exemplo, em "Hannah Arendt e a Revolução", assevera que as afirmações da autora carecem de fundamentação sólida, pois são guiadas por um "matiz metafísico e normativo" e não são corroboradas por análises das ciências sociais. ${ }^{13} \mathrm{Na}$ perspectiva do historiador, Arendt acerta ao entender os conselhos como a verdadeira tradição revolucionária, contudo, falha ao renunciar ao estudo histórico detalhado de tais instituições. ${ }^{14}$ Dessa forma, a autora teria criado um tipo ideal ao identificar nos conselhos revolucionários a participação "tal e como se concebiam talvez originalmente na polis grega" (Hobsbawn, Revolucionários, p. 204). ${ }^{15}$ Além disso, o autor afirma que o conceito de liberdade não está claramente definido no livro e que a pobreza - a questão social aparece como o fator que corrompe toda revolução.

Pode-se notar que Hobsbawn espera que as revoluções sejam tratadas por meio da história social e das ciências sociais. No entanto, defendemos aqui que Sobre a Revolução discute o deslocamento dos principais conceitos políticos a partir dos eventos revolucionários do século XVIII e, nesse sentido, este livro está mais próximo da história dos conceitos e da teoria política do que da história social ou da sociologia. Koselleck esclarece sobre a diferença entre estas duas diferentes abordagens: a história social utiliza textos para investigar os fatos, uma vez que seu objeto consiste nas relações entre grupos

\footnotetext{
${ }^{13}$ Conferir em Hobsbawn, Revolucionários, p. 202.

${ }^{14}$ Ver em Hobsbawn, Revolucionários, p. 205-206.

${ }^{15}$ É importante pontuar que Hobsbawn destaca a influência grega no pensamento de Arendt, mas negligencia o peso da experiência da República romana em Sobre a Revolução.
} 
sociais e nos fatos e circunstâncias que abarcam um evento. Já a história dos conceitos parte do princípio de que há uma relação entre linguagem e evento e nessa medida se ocupa de discursos para analisar os vocábulos veiculados em um evento ou época, isto é, interpretar e explicar termos centrais do ponto de vista político. Para Koselleck, a história dos conceitos é capaz de investigar conteúdos que não podem ser revelados a partir da análise empírica. ${ }^{16}$ Além disso, mostraremos que a referência à polis grega (e também à República romana) não indica um idealismo, mas consiste em um procedimento que permite identificar os elementos originários da política e os deslocamentos que as revoluções promoveram. ${ }^{17}$ Ainda, a centralidade que Hobsbawn confere à questão social em detrimento da discussão que a autora faz acerca das concepções de vontade geral, soberania e fundação consiste em mais um indício de que ele não entendeu o livro como um estudo de teoria política. Levando isso em conta, vemos a importância de desenvolver um paralelo entre a reflexão arendtiana acerca das revoluções e a história dos conceitos.

Com relação aos autores que colocam Sobre a Revolução no centro de sua análise, identificamos duas formas gerais de trabalhar: uma consiste em escolher um conceito ou tema específico para ser profundamente discutido; e a outra apresenta as ideias de Arendt sob a influência de uma tradição do pensamento ou de um determinado autor. Ou seja, apresenta uma leitura enviesada por outras teorias e autores.

No primeiro caso, destacam-se os trabalhos de Kalyvas, Arato e Bignotto. Kalyvas interpreta Sobre a Revolução a partir das categorias de política ordinária e extraordinária. Para ele, tradicionalmente, a política ordinária é monopolizada por elites políticas, partidos burocratizados, representação, eleição e rígidos procedimentos institucionais, por isso é caracterizada pela baixa participação popular nos processos de decisão. Ao contrário, a política extraordinária e democrática geralmente é experimental e provisória, envolve alto grau de mobilização e a abertura de espaços públicos informais e não institucionalizados que desafiam o status quo e a autoridade pré-estabelecida. Nos momentos em que a

\footnotetext{
${ }^{16}$ Conferir em Koselleck, Futuro Passado, p. 97-110.

${ }^{17}$ Segundo Koselleck, a história de um conceito coloca em evidência a estratificação de um mesmo conceito em diferentes épocas. Isto permite avaliar e medir permanências ou alterações na história. Ver em Futuro Passado, p. 115.
} 
política extraordinária emerge, são rearranjados as normas e valores fundamentais que regulam as instituições onde a política regular e ordinária se desenrola. ${ }^{18}$

Contudo, a partir do pensamento de Carl Schmitt, a política extraordinária passou a ser entendida como exceção, como ato de vontade soberana, relacionada ao decisionismo. De acordo Kalyvas, Sobre a Revolução oferece um modelo alternativo e coerente para tratar da política do extraordinário ao abordar o tema dos novos inícios na medida em que não relaciona atos extraordinários com exceção.

Para ele, o pensamento de Arendt procura articular política extraordinária e ordinária na medida em que discute a relação entre novos inícios e mudança radical com continuidade legal. Para este comentador, a autora entende que, apesar de uma revolução gerar poder extraordinário, seu objetivo consiste em institucionalizar este poder por meio de uma constituição, ou seja, da criação de um corpo político onde a liberdade e a participação no governo sejam ordinárias e regulares. A autora se ocupa com a discussão sobre a institucionalização de espaços de ação, pois a noção de revolução permanente mostrou que a ação não perdura muito tempo quando não está apoiada em estruturas e leis. Entretanto, ela sustenta que o sistema legal não pode abolir a espontaneidade de ação e de associação, não pode petrificar a vida política ao impedir que novidades surjam no mundo. Assim, para Kalyvas, ao afirmar que a liberdade pública deve ser abrigada por instituições e uma estrutura, a política extraordinária é conciliada com governo constitucional duradouro na obra de Arendt. $\mathrm{O}$ pensamento da autora trata de um modo de ação extraordinária que não implica na destruição da autoridade do corpo político.

Além disso, em Sobre a Revolução, Arendt critica as noções de soberania e vontade e valoriza o debate público. Segundo Kalyvas, ela aponta que a soberania coloca em risco a esfera política ao substituir a pluralidade do debate público pela hierarquização e pela relação de mando e obediência. A vontade - por ser volúvel e inconstante uma vez que muda impetuosamente conforme os desejos e humores -, ao guiar as decisões públicas, fatalmente leva instabilidade e inconstância ao corpo político. Ainda, de acordo com o comentador, quando a autora coloca a persuasão e a deliberação comum no coração do poder constituinte, escapa da glorificação da vontade popular como expressão da soberania.

\footnotetext{
${ }^{18}$ Ver em Kalyvas, Democracy and the Politics of the Extraordinary, p. 6-8.
} 
Nesse sentido, Kalyvas foca nos escritos arendtianos que tratam de uma política extraordinária e sua sobrevivência dentro de uma ordem constitucional estável. O escopo de sua análise discute algumas categorias políticas importantes presentes em Sobre a Revolução. No entanto, o autor não trata das narrativas das revoluções nem da mudança de significado dos conceitos ao longo do tempo.

Por sua vez, Arato examina o pensamento de Arendt a propósito de sua análise das mudanças de regimes, principalmente as mudanças no leste europeu entre os anos de 1989 e 1991. Segundo este autor, Arendt indica três formas de criação de constituição a partir de exemplos históricos. A primeira foi inspirada no caminho britânico, em que a constituição adquiriu sua forma ao longo de diversas legislaturas, em razão de mudanças históricas e dos costumes. É, portanto, uma constituição que se forma num longo processo de evolução. Já a segunda forma de criação de constituição exige pouco tempo, uma vez que consiste em um ato de governo. Foi o caso de muitas Cartas Constitucionais feitas na Europa durante o pós $1^{\mathrm{a}}$ e $2^{\mathrm{a}}$ Guerras Mundiais, que em grande parte promoveram a transição de um governo autoritário para um democrático. A terceira forma de criação de constituição foi retirada da experiência das Revoluções Americana e Francesa, em que assembleias revolucionárias propiciaram amplo debate e participação na criação de instituições livres e de um novo governo. ${ }^{19}$

Para Arato, Arendt, ciente das perplexidades inerentes ao novo início, distingue as origens do poder e a fonte de autoridade, em outras palavras, quem se envolveu na criação da constituição e como foi este processo. Nessa perspectiva, o poder se torna uma questão de fato e a autoridade uma questão de validade normativa. Para ilustrar isso, o autor se refere ao poder e à autoridade na América do Norte: um está fundado na ação do povo e o outro na maneira e na forma como se esboçaram e ratificaram as convenções. ${ }^{20}$ Nesse sentido, o recorte de pesquisa deste autor discute apenas os conceitos de constituição e autoridade, e não trata de outros conceitos políticos importantes presentes em Sobre a Revolução.

Já no Brasil, os estudiosos que discutem o livro de Arendt dedicado às revoluções focam na relação do pensamento da autora com o republicanismo. Além disso, indicam

\footnotetext{
${ }^{19}$ Conferir em Arato, Civil Society, Constitution, and Legitimacy, p. 232 e 240.

${ }^{20}$ Ver em Arato, Civil Society, Constitution, and Legitimacy, p. 242.
} 
que a autora se afasta tanto do marxismo como do liberalismo. ${ }^{21}$ Bignotto, por exemplo, entende que a maior contribuição de Arendt para o pensamento político foi considerar que toda fundação precisa, além de uma constituição, de um enraizamento simbólico. Para o autor, Arendt, ao demonstrar a dimensão simbólica da fundação, isto é, que uma constituição envolve mais do que um problema técnico-jurídico na medida em que requer apoio e suporte dos cidadãos, faz um contraponto às correntes do pensamento do século XX que consideram a Constituição simplesmente como a escolha racional de princípios que se traduzem nas instituições. ${ }^{22}$

Bignotto ainda indica a forma pela qual a autora procura entender o evento revolucionário na França. De acordo com ele, Robespierre é, para Arendt, a figura emblemática da Revolução: por meio de suas ideias é revelado o momento e o motivo de conversão da liberdade para a necessidade na Revolução Francesa. ${ }^{23}$ Robespierre, ao mobilizar constantemente a vontade do povo, sempre volúvel, deixou de procurar uma forma institucional para suas ações, isto é, não apoiou as Cartas Constitucionais, nem mesmo a jacobina. Além disso, relacionou a vontade do povo com a questão social.

Para Bignotto, Arendt não considera seriamente as ideias de outros revolucionários, como Mirabeau e Condorcet, que defendiam que a revolução atingiria seu objetivo por meio da redação de uma nova Constituição.

No entanto, em nossa perspectiva, embora Arendt cite mais Robespierre, a autora aponta que as ideias de Sieyès também foram decisivas para o curso da Revolução Francesa. Veremos no segundo capítulo deste trabalho que Sieyès foi responsável por defender a soberania como fundamento da República francesa e por defender que a vontade da nação pode ser representada pela Assembleia Geral. Nesse sentido, as ideias deste revolucionário também contribuíram para a centralização do poder e para o uso da violência.

\footnotetext{
${ }^{21}$ Conferir artigos publicados nos Cadernos de Ética e Filosofia Política, no 23 , de Oliveira ("Revolução como fundação no pensamento de Hannah Arendt"), que trata da relação entre fundação, novo e liberdade; o artigo de Alves Neto ("Crítica arendtiana à democracia liberal e o sentido político da liberdade"), que discute a crítica à democracia liberal por meio do conceito arendtiano de liberdade; e o artigo de Müller ("Revoluções Americana e Francesa: luta por liberdade ou libertação?"), que investiga a distinção entre liberdade e libertação, sobretudo na Revolução Americana.

${ }^{22}$ Conferir em "Hannah Arendt e a Revolução Francesa", p. 41 e 56.

${ }^{23}$ Ver em "Hannah Arendt e a Revolução Francesa", p. 47.
} 
De qualquer forma, ao nosso ver, Bignotto identifica o modo pelo qual a autora constrói a narrativa sobre as revoluções: por meio das ideias de figuras emblemáticas. Se na Revolução Francesa a autora investiga as concepções de Robespierre (e também de Sieyès) para a compreender este evento, na Revolução Americana as ideias de Jefferson e Madison são as bases para sua reflexão. Este é um dos elementos que indicam que Sobre a Revolução acaba por constituir uma forma particular de história dos conceitos. O livro não só indica o deslocamento de conceitos políticos, como também avalia o sentido e o curso das revoluções por meio das ideias dos revolucionários mais influentes, as quais, segundo a autora, foram mais apoiadas pelo povo. Arendt centra sua análise em Jefferson e nos federalistas em razão de sua força no debate constitucional na América do Norte. Ela foca sua narrativa em Robespierre pelo fato de este revolucionário ter centralizado as decisões e o governo da França. Além disso, a autora procura investigar quais das ideias dos homens das revoluções do século XVIII ainda têm força no imaginário e na teoria política contemporânea e quais se perderam. Por exemplo, Arendt entende que a noção de vontade e soberania de Rousseau foram apropriadas por Robespierre e são encontradas no pensamento de Schmitt. ${ }^{24}$

Dessa forma, entendemos que alguns dos aspectos problemáticos na obra de Arendt podem ser causados justamente pelo procedimento de articular uma história dos conceitos. Para Bignotto, um dos equívocos provocados pela autora consiste em criar a impressão nos leitores de que há uma identidade entre Rousseau e Robespierre, sendo que a interpretação do revolucionário sobre a obra de Rousseau não foi a mais influente. ${ }^{25} \mathrm{O}$ autor chama a atenção para o fato de que não foi só Robespierre que evocava os conceitos rousseaunianos. Muitos, até mesmo monarquistas, faziam referência ao pensamento de

\footnotetext{
${ }^{24}$ Embora a ligação entre Rousseau e Schmitt seja indicada somente na nota 21 do artigo "Que é liberdade?", ela é esclarecedora na medida em que explica as distorções de interpretação da autora: Arendt ataca as noções rousseanianas para atingir Schmitt. Ver em Entre o Passado e o Futuro, p. 212. De acordo com Kalyvas, a crítica arendtiana ao conceito de soberania e à noção de poder constituinte fica mais clara ao ser contrastada com a teoria schmittiana de política e poder constitucional. Ver em Democracy and the Politics of the Extraordinary, p. 194

${ }^{25} \mathrm{O}$ autor indica também as interpretações equivocadas que os conceitos rousseaunianos sofreram. Por exemplo, a vontade do povo de Robespierre foi entendida como idêntica à vontade geral. No entanto, Bignotto adverte que, ao contrário de Robespierre, Rousseau preocupa-se com o estabelecimento de instituições e leis fixas. O poder soberano em Rousseau não é ilimitado, ele não pode ultrapassar os limites das convenções gerais.
} 
Rousseau. ${ }^{26}$ Ao tentar indicar uma linha de continuidade entre Rousseau, Robespierre e Schmitt, a autora, além de tratar os conceitos rousseaunianos de forma distorcida, ainda deixa de explorar a disputa de vários revolucionários em torno do pensamento de Rousseau. Nesse sentido, embora Bignotto tenha indicado importantes questões com relação à interpretação arendtiana da Revolução Francesa, o autor não discute as alusões a Sieyès e não trata de outros pontos da obra relativos à Revolução Americana.

Há ainda comentadores que interpretam o livro Sobre a Revolução por meio de uma tradição de pensamento ou por meio de questões de outros autores. Wellmer, por exemplo, descarta alguns temas no pensamento arentiano em favor de uma abordagem habermasiana. O autor acerta ao avaliar que Arendt, quando reflete sobre as revoluções, tenta combater duas noções de política, a saber, a liberal e a marxista. No ponto de vista do comentador, a autora indica que ambas entendem a ação política como instrumental: no liberalismo, a política consiste em um meio para alcançar o bem estar e a felicidade privada; no marxismo, ela é um instrumento para alcançar a justiça social. Ao contrário, para Arendt, a atividade política tem fim em si mesma, ela não almeja um objetivo em outra esfera. Dito de outra forma, a esfera política é dotada de autonomia, não está subordinada à esfera social ou ao domínio privado. Nessa medida, o conceito arendtiano de política faz uma crítica radical da Modernidade e de duas importantes vertentes do pensamento moderno. Além disso, a autora revaloriza a ação e o discurso e ainda insiste na autonomia da esfera pública: afirma que esta não possui um fundamento normativo e externo. Segundo Wellmer, isto permite integrar suas reflexões dentro da teoria democrática contemporânea e o autoriza a traçar um diálogo entre Arendt e Habermas. ${ }^{27}$

De certa forma, o autor sugere que os problemas apontados por Arendt com relação ao pensamento liberal e marxista podem ser resolvidos ao se adotar a perspectiva habermasiana. Com isso, Wellmer deixa de tratar algumas questões que a autora propõe. Isto ocorre com a reflexão sobre o sistema de conselhos, que abarca a discussão de participação, representação e formas de interligação de diferentes centros de poderes. $\mathrm{O}$ comentador afirma que entende a ideia arendtiana de sistema de conselhos como uma metáfora para uma rede de instituições, organizações e associações autônomas onde as

\footnotetext{
${ }^{26}$ Conferir em "Hannah Arendt e a Revolução Francesa", p. 50.

${ }^{27}$ Conferir em "Arendt on Revolution", p. 225 e 226.
} 
pessoas podem participar como iguais. Tal rede pode se conectar horizontal e verticalmente e pode representar tanto um sistema político federal, isto é, o Estado, quanto a sociedade civil. ${ }^{28}$

Porém, esta relação entre sistema de conselhos e as categorias de Estado e sociedade civil proposta por Wellmer parece trazer mais problemas do que ganhos. Um dos problemas seria a questão do poder. Enquanto, para Arendt, o sistema de conselhos gera poder - categoria eminentemente política -, para Habermas, a sociedade civil pode ter influência sobre o sistema político, isto é, pode gerar poder social, mas não produz poder político, que significa potencial de tomar decisões. ${ }^{29}$ Assim, a relação entre os conceitos de sistema político e sociedade civil com sistema de conselhos ou introduz uma divisão no poder (entre o social e o político) e uma divisão de participação (entre aqueles que agem no âmbito do Estado e aqueles que agem na sociedade civil), o que não se observa no pensamento arendtiano; ou faz com que os conselhos sejam tomados como metáforas e não como um novo sistema de poder e uma forma de corpo político possível.

Além disso, Wellmer, na última parte de seu texto, critica três pontos na obra de Arendt: a interpretação e implementação de direitos humanos básicos; a questão da justiça social; e o problema do surgimento de particularismo nos espaço públicos de liberdade. ${ }^{30}$ Sobre os direitos básicos, o autor afirma que direitos humanos existem de forma histórica e concreta em um sistema de instituições e interpretações. Nesse sentido, os direitos individuais dependem de instituições democráticas e de uma esfera pública para serem assegurados. Por isso, as liberdades privada e pública, entendidas de maneira adequada, dependem uma da outra.

Neste ponto, duas questões são negligenciadas pelo autor: a relação entre libertação, direitos civis e liberdade e a indicação de que há tanto espaços públicos espontâneos quanto institucionalizados. Arendt trata da relação entre direitos privados e políticos ao dizer enfaticamente que a liberdade é experimentada ao se agir no espaço público e que para agir é preciso antes ter se liberado das necessidades do corpo e não estar sob domínio de outrem. É possível inferir disto que os direitos civis garantem em certa

\footnotetext{
${ }^{28}$ Ver em"Arendt on Revolution", p. 224.

${ }^{29}$ Conferir em Direito e Democracia: entre a facticidade e validade II, p. 95 e 96.

${ }^{30}$ Ver em "Arendt on Revolution", p. 233.
} 
medida que uns não fiquem sob o arbítrio de outros, assim, eles se relacionam com o direito de participar na atividade política. No entanto, essa anterioridade da libertação e dos direitos com relação à liberdade política está garantida em um corpo político bem constituído, como a polis ateniense e a República romana. Nas Revoluções Americana e Francesa, o povo foi capaz de agir antes de ter direitos civis estabelecidos. É justamente esta diferença entre espaço público institucionalizado e espontâneo, ou, nas palavras de Kalyvas, a tensão entre política ordinária e extraordinária que Wellmer perde de vista.

$\mathrm{O}$ segundo ponto que o autor critica está ligado à questão social. Arendt ocasionalmente sugere que o problema da pobreza pode ser resolvido por uma burocracia que funcione corretamente, mas, para o autor, isto é "ingênuo ao extremo". ${ }^{1}$ De acordo com ele, teria sido mais razoável a autora considerar que as questões sociais podem se tornar um interesse comum dentro da esfera pública. Aqui fica claro que, na perspectiva de Wellmer, a autonomia da política em Arendt significa que a esfera política não só possui um conteúdo próprio, mas também está separada das outras esferas.

Apesar da insistência da autora na distinção das esferas privada, social e política, entendemos que esta distinção implica em identificar fronteiras, relações e tensões entre as esferas, mas de forma alguma a completa separação delas. Arendt em momento algum afirma que as questões sociais não podem se tornar tema de interesse e debate comum. Contudo, ela aponta claramente qual o risco que a questão social pode introduzir no espaço público: os debates e decisões que envolvem a sobrevivência e as necessidades da vida, assim que se mostram urgentes, podem fazer com que o debate ampliado seja abandonado em favor da rápida decisão de especialistas. Os espaços públicos, nestes casos, são reduzidos uma vez que a centralização é mais eficaz para resolver as urgências da vida biológica. Além disso, a autora mostra que, a partir da Modernidade, a vida biológica e o trabalho se tornaram a principal preocupação e atividade, nesse contexto, o risco da administração suplantar a ação é ainda maior.

Concordamos com o comentador em que a autora poderia tratar mais dos momentos em que o debate da questão social não degenerou a política. Ela poderia, por exemplo, ter indicado com mais clareza como e quando o debate sobre a miséria na França e a escravidão na América do Norte seguiram as formas da atividade política e em que ponto

\footnotetext{
${ }^{31}$ Conferir em “Arendt on Revolution”, p. 234.
} 
esvaziaram ou dificultaram a ação. Nesse sentido, embora a crítica de Wellmer seja pertinente, ele minimiza as considerações acerca dos riscos que a questão social traz para a política.

O último ponto criticado no livro Sobre a Revolução diz respeito à tendência de particularismo de diversas esferas públicas de liberdade reais. Em outras palavras, as instituições políticas, associações e assembleias locais podem defender interesses particulares em detrimento de interesses gerais. Para Wellmer, a pluralidade dos espaços públicos locais depende das instâncias legislativa, executiva e judicial centrais, estas instâncias gerais evitam que os interesses particulares se sobreponham ao bem público.

Todavia, Arendt indica uma preocupação com o surgimento de facções que acabem com o debate ampliado e a pluralidade. Ela trata deste problema na Revolução Francesa, mas, ao contrário do comentador, indica que foi uma instância central que não tolerou a pluralidade de opiniões e a existência de diversos centros de poder. A autora mostra que a partir do interesse de um partido, o jacobino, de controlar a Assembleia Nacional, os espaços públicos locais foram paulatinamente ocupados e a pluralidade de opiniões foi progressivamente solapada. A reflexão arenditiana sobre esta disputa entre partido e assembleias locais aponta para a questão da disputa de interesses diferentes, do surgimento da opinião pública e da unanimidade.

Pode-se notar que Wellmer, ao tratar dos problemas postos por Habermas, tais como a garantia dos direitos humanos básicos, da justiça social e do interesse geral e público, afasta-se de questões e tensões importantes que se encontram no pensamento de Arendt.

Já Waldron interpreta as ideias arendtianas de um ponto de vista liberal, uma vez que destaca dos escritos da autora os trechos que tratam da garantia dos direitos individuais e da organização da ação no parlamento e silencia com relação aos trechos que tratam da liberdade e da participação ampliada, isto é, fora do parlamento. Nesse sentido, Arendt é interpretada como uma defensora do governo limitado, o qual deve instituir direitos civis e restringir a ação por meio da representação.

Waldron enfatiza na obra de Arendt a estrutura, formalidade e procedimentos próprios da atividade política. De acordo com ele, a maioria dos comentadores do pensamento arendtiano acentua na ação dois aspectos, a saber, a espontaneidade e o 
espírito agosnístico - que significa a busca por meio de feitos heroicos e memoráveis da distinção do agente, do desvelamento de sua singularidade - em detrimento dos aspectos institucionais e constitucionais da ação. ${ }^{32}$

Nas palavras do autor, “o auto-desvelamento agonístico e a 'irregular' política dos conselhos e da desobediência civil são alternativas às formas responsáveis de política constitucional". ${ }^{33}$ Por isso, ele procura retirar dos textos de Arendt aquilo que seria o mínimo necessário para um corpo político, isto é, quais estruturas, formalidades e procedimentos resguardam e permitem a ação. Em sua leitura, a constituição consiste em uma espécie de estrutura que vincula os cidadãos e também estabelece cercas, divisões e limites. Três limites são encontrados nos textos da autora: o que delimita a igualdade, uma vez que a igualdade entre diversas pessoas é construída artificialmente e só pode ser estabelecida em um espaço delimitado; o que divide espaço público e espaço privado; e aquele que separa os indivíduos uns dos outros, garantindo a privacidade e segurança de cada um. ${ }^{34}$

Segundo Waldron, a afirmação de que uma república bem ordenada envolve debate e deliberação significa que Arendt indica a necessidade de regras que definam o funcionamento do debate público: como ele se inicia e é concluído, como as pautas são estabelecidas, quem pode falar, com que frequência e por quanto tempo, quem pode interromper etc. ${ }^{35}$ Para o comentador, tais regras marcam a distinção entre a política bem estruturada e a opinião de massa, que surge em um contexto extraparlamentar. De acordo com ele, a ação sem estrutura é perigosa, sem futuro promissor, pois pode levar ao terror.

Neste ponto é possível notar que o autor identifica estrutura com parlamento e ainda sugere que as ações fora das instituições se assemelham à mobilização de massa. Nesse sentido, Waldron considera Arendt mais interessada na política institucional e ordinária do que na ação em espaços públicos não institucionalizados. Esta leitura é antagônica à de Kalyvas: enquanto um separa e opõe política ordinária e extraordinária, o outro discute a relação entre elas.

\footnotetext{
${ }^{32}$ Conferir em “Arendt's Constitutional Politics", p. 202.

${ }^{33}$ No original: "agonistic self-disclosure and the 'irregular' politics of councils and civil disobedience are alternatives to responsible modes of constitutional politics" (“Arendt's Constitutional Politics", p. 203).

${ }^{34}$ Ver em "Arendt's Constitutional Politics", p. 206 e 205.

${ }^{35}$ Conferir em "Arendt's Constitutional Politics", p. 210.
} 
Para Waldron, embora a autora não tenha desenvolvido uma reflexão sobre arranjos eleitorais, ela se ocupou de três estruturas políticas imprescindíveis: representação, partidos e federalismo. Segundo o autor, por meio dos partidos e da representação, as opiniões podem ser peneiradas e purificadas de forma a impedir o surgimento da opinião de massa. Ainda, ele ressalta que o sistema bipartidário proporciona maior cooperação entre os grupos políticos e evita o risco de fragmentação dos partidos e sua supressão pelo movimento de massa.

Nesta passagem, o comentador, ao tratar de representação e sistema partidário, desvia-se de Sobre a Revolução, em particular do último capítulo do livro, e vai em direção a Origens do Totalitarismo. Enquanto este livro discorre sobre a crise do sistema partidário e a consequente abertura para os movimentos totalitários - que foram mais bem combatidos onde o bipartidarismo vigorava -, aquele conta com o elogio ao sistema de conselhos e à participação ampliada e, além disso, trata da crítica destinada ao sistema de partidos e às teorias de representação. Assim, o autor dá mais destaque à representação do que à participação, valoriza o bipartidarismo em detrimento do sistema de conselhos, o que não nos parece correto, entre outros motivos, porque Sobre a Revolução é posterior a Origens do Totalitarismo.

Waldron, ao tratar de estruturas, procedimentos e formalidades, acaba por restringir a ação política à atividade dentro de um parlamento ou partido. Expressão disso é a definição do conceito de constituição como o conjunto de leis que regulam as instituições políticas. $\mathrm{O}$ autor não trata detidamente do outro significado de constituição, a saber, o ato de um povo de constituir um novo corpo político. Em outras palavras, constituição, para Arendt, carrega dois sentidos, a saber, o de conjunto de leis e o de fundação. Vale salientar que a ação fundadora em uma revolução é realizada anteriormente à cristalização de instituições e normas do novo corpo político.

Nesse sentido, há duas razões que nos mostram que não é produtivo refletir sobre a estrutura política, as leis e a liberdade institucionalizada sem tratar da ação que abre um espaço político inesperadamente. Primeiro, a constituição em uma revolução nasce de uma ação inesperada e se dá fora de espaços públicos institucionalizados. Segundo, a atividade institucional mantém poder e se sustenta somente com o apoio das opiniões dos cidadãos. Mais do que isso, a política institucional se renova e revigora por meio da ação na praça 
pública. Com isso, vemos que o agir institucional, por mais importante que seja, não pode substituir por completo ou acabar com a ação espontânea.

Levando isso em conta, Waldron parece cometer o equívoco oposto daqueles comentadores que enfatizam a espontaneidade da ação e o espírito agonístico: estes outros obliteram os elementos estruturais, formais e procedimentais da ação, ao contrário, Waldron acaba por negligenciar a participação ampliada e a política extraordinária.

É curioso que tanto Wellmer quanto Waldron tenham lido a obra Sobre a Revolução influenciados por outros pensadores ou teorias. Isso nos leva a indagar o motivo que explica estas interpretações. Pode-se notar que ambos os comentadores trabalham os conceitos políticos de Arendt sem relacioná-los fortemente com as noções de revolução e fundação. Isto se deve possivelmente aos desfechos malfadados de alguns levantes revolucionários do século XX que contribuíram para que a noção de revolução fosse relacionada com ditadura, totalitarismo ou com restauração. ${ }^{36}$ Ainda, alguns teóricos passaram a nomear de revolução golpes de Estado e intervenções militares. ${ }^{37}$ Soma-se a isso a descrença que surgiu com a queda do muro de Berlim, de uma revolução criar um corpo político constitucional e estável que promova a justiça social. Neste contexto em que a revolução saiu do horizonte de expectativas, saiu da ordem do dia, o pensamento arendtiano passou a ser vinculado com teorias que prescindem das categorias de revolução e de ação fundadora.

Além deste desgaste do conceito de revolução, a partir dos anos de 1980, houve uma revisão histórica e teórica das Revoluções Francesa e Americana. Em outras palavras, dos tempos de Arendt para cá, o quadro teórico que interpreta as duas revoluções foi alterado de forma significativa.

\footnotetext{
${ }^{36}$ Ver em Kalyvas, Democracy and the Politics of the Extraordinary, p. 3.

${ }^{37}$ Conforme Arato, há certa confusão e inconstância na definição do conceito de revolução: os teóricos não se decidem se revolução é a troca de governantes ou a mudança na forma de governo. Alguns denominam vários fenômenos de revolução, incluindo golpes de Estado, intervenção militar. Conferir em Civil Society, Constitution, and Legitimacy, p. 82 e 83.
} 
$\underline{\text { Revisão histórica das revoluções }}$

Nas décadas de 1950 e 1960, as duas grandes tradições hegemônicas do pensamento na academia eram o marxismo e o liberalismo. De acordo com Arendt, a primeira elegeu a Revolução Francesa como modelo. E como os franceses em 1789 reivindicaram ao mesmo tempo a cidadania, o fim dos privilégios e também medidas administrativas para acabar com a miséria, a tradição marxista vinculou revolução com transformação social, igualdade, liberdade e emancipação; relacionou política e questões sociais, associou ação, violência e administração dos bens. Segundo a autora, esta tradição não considerou a Revolução Norte-Americana. Em consequência disto, as novidades que emergiram nesta revolução foram negligenciadas: o federalismo entendido como diversos centros de poderes coordenados, a Suprema Corte como instituição responsável por resguardar a Constituição e a ação nas assembleias municipais não foram investigadas e aprofundadas pelo pensamento teórico revolucionário.

Já o liberalismo concorreu para o esquecimento da Revolução Americana ao tomar os EUA como modelo de sociedade que promove o bem estar individual por meio de um Estado que garante os direitos civis e o livre empreendimento sem relacionar estes direitos com a ação de resistência e a participação ampliada na fundação do corpo político.

Neste contexto, Arendt tentou influenciar o debate acadêmico e político ao formular outro conceito de revolução, criticar a Revolução Francesa como modelo e tratar da Revolução Americana. Nas palavras de Bignotto, "Escrito num contexto no qual as disputas entre marxistas e liberais dominavam o cenário do pensamento político ocidental, Arendt se propôs a trilhar um caminho diferente daquele das correntes de pensamento dominantes." ("Hannah Arendt e a Revolução Francesa", p. 42). Na perspectiva arendtiana, para compreender o significado das revoluções, é preciso considerar a ação revolucionária no Velho e no Novo Mundo.

Para a autora, revolução está ligada à liberdade e à isonomia, está relacionada com a participação ampliada no debate público, com o igual direito de falar, ouvir e agir. Os homens das Revoluções Norte-Americana e Francesa, para garantir a liberdade de agir e a isonomia, romperam com a autoridade e forma de governo que os oprimia e reduzia o espaço público: o governo colonial inglês e a monarquia absolutista na França. A partir da 
participação em assembleias municipais, clubes e sociedades, eles buscaram fundar um novo corpo político sem precedentes na história, pois visaram a constituir um novo sistema de poder e uma nova autoridade.

Como foi mencionado acima, na década de 1980, a noção de que a Revolução Francesa consistia em modelo começou a ser atacada e o processo constitucional Norte Americano foi recuperado. Entretanto, como veremos a seguir, isso não ocorreu nos termos de Arendt. Dito de outra forma, o que foi exaltado pela autora - como as noções de liberdade e isonomia, a ação e feitos nas assembleias municipais, clubes e sociedades e a maneira revolucionária de coordenar centros de poder - continuou a ser desconsiderado pelo pensamento político hegemônico.

Veremos que no livro Dicionário Crítico da Revolução Francesa, ${ }^{38}$ considerado atualmente como a versão histórica mais acurada sobre aquela revolução, a ação na Assembleia Nacional é valorizada em detrimento da ação popular.

No artigo dedicado aos clubes e sociedades populares, em primeiro lugar é apresentado o caráter destes órgãos populares e depois sua história é narrada. ${ }^{39}$ As sociedades e clubes são definidos como parte da máquina jacobina. Nas palavras de Gueniffey e Halévi, desde 1789 tais sociedades eram o lugar "de aprendizado do discurso igualitário, do trabalho da unanimidade, do reino da opinião" (Dicionário Crítico da Revolução Francesa, p. 476).

Ainda segundo os autores, estes órgãos começaram a surgir em 1789. Um dos primeiros foi o Clube Bretão, formado em Versalhes na véspera dos Estados Gerais com o objetivo de reunir de maneira regular os delegados do Terceiro Estado da Bretanha para debater questões políticas. Na prática, o Clube Bretão alinhava os delegados numa mesma posição para a votação nos Estados Gerais.

Em diversas cidades espalhadas pela França, clubes e sociedades populares foram formados e, em pouco tempo, elas compuseram uma rede por meio da filiação à sociedade matriz parisiense. Paris tentava organizar essa sociabilidade ativa e difusa por meio de um

\footnotetext{
${ }^{38}$ Organizado por François Furet e Mona Ozouf. Publicado em 1988.

${ }^{39}$ Autores Patrice Gueniffey e Ran Halévi.
} 
comitê de correspondência que redigia circulares para promover a adesão dos demais municípios. No início de 1790 já haviam filiado 50 cidades. ${ }^{40}$

Para os autores, a partir de meados de 1791, as sociedades já eram instrumentos de poder - deveriam ajudar na execução das leis, vigiar funcionários públicos, fazer uma espécie de tribunal da opinião pública e denunciar as más leis. Numa palavra, dedicavamse à vigilância e à delação. ${ }^{41}$

Em 1793, os clubes e sociedades, por meio dos expurgos periódicos, tinham como objetivo manter a unanimidade de opinião. A revolução tinha decretado que o poder residia na nação, una e indivisível. Nesta perspectiva, a atividade nas sociedades e clubes só poderia ser mantida se produzisse uma opinião unânime. Nesse contexto, tornaram-se uma peça da máquina governamental - apenas serviam para sancionar as diretivas do governo.

Em 1794, começa a decadência destes órgãos com a proibição de qualquer filiação e correspondência entre as sociedades.

De acordo com Gueniffey e Halévi, as sociedades e clubes populares, desde seu surgimento, já estavam desenhados para se tornarem mais tarde peças do maquinário do período do terror. Para eles, estes órgãos desde o começo estavam comprometidos com a unanimidade e a vigilância.

A nosso ver, os autores sofrem de uma ilusão retrospectiva, isto é, tomam a forma final dos clubes e sociedades por sua finalidade, com isto definem estes órgãos como máquinas do poder jacobino. Eles não consideram que estes órgãos populares tiveram uma historicidade e mudaram com o decorrer da Revolução: no começo, eram espaços dedicados ao pensamento e ao debate sobre a política, mas no decorrer da revolução desviaram de seu objetivo inicial ao mobilizar votos, intimidar adversários para fabricar consenso.

Por meio desta revisão histórica da Revolução Francesa, os órgãos populares passaram a ser vistos negativamente enquanto que a ação dentro da Assembleia Nacional foi mais destacada.

O artigo sobre a Constituição, escrito por Baker, foca nos discursos dos deputados dentro da Assembleia, trata do debate sobre a Constituição de 1791. Para o autor, a

\footnotetext{
${ }^{40}$ Ver em Dicionário Crítico da Revolução Francesa, p. 479-480.

${ }^{41}$ Conferir em Dicionário Crítico da Revolução Francesa, p 485.
} 
principal disputa entre os deputados era em torno da seguinte questão: a revolução iria restaurar uma antiga constituição que fora deturpada pelo absolutismo ou iria criar uma nova? $?^{42}$

Nesta disputa, a discussão acerca dos direitos fundamentais foi decisiva. O texto da Declaração dos Direitos do Homem indicou como identificar se um povo possui uma constituição ou não. No Artigo 16, lê-se: “Toda sociedade na qual não se garantem direitos, nem se determina a separação dos poderes, não possui Constituição". Esta afirmação, somada às reivindicações revolucionárias de limitar o poder arbitrário do monarca e de acabar com os privilégios, levou a uma conclusão: a França não possuía uma constituição e precisava criar uma. ${ }^{43}$

Neste contexto, a nova Constituição deveria ter três fundamentos: os Direitos do Homem, a concepção de que é preciso estabelecer a divisão e o equilíbrio dos poderes para que nenhum poder extrapole seus limites e a de que o governo deve seguir a vontade geral.

Após uma longa disputa lexical sobre o significado do termo vontade geral, a Assembleia Nacional concluiu que ela poderia ser expressa somente por meio de uma assembleia de representantes. Para conter o poder da assembleia e impedir que os representantes abusassem de seu cargo, foi estabelecido o veto real: o monarca podia limitar o poder dos deputados por meio do veto aos decretos da Assembleia. De acordo com Baker, o veto real conduziu ao conflito entre os delegados e a coroa, o que paulatinamente minou a sustentação da Constituição e levou à sua queda em $1792 .{ }^{44}$

Segundo o autor, a Revolução Americana foi capaz de transformar a vontade revolucionária em uma Carta Constitucional estável. Na França, ao contrário, abriu-se um hiato entre revolução e constituição na medida em que não se conseguiu produzir uma Carta Constitucional duradoura. Pode-se notar que, neste artigo, a redação da Constituição de 1791 é explicada somente por meio dos debates dentro da Assembleia Nacional.

Michellet apresenta outra interpretação em seu livro História da Revolução Francesa, pois indica como as ações fora da Assembleia acabaram por influenciar os rumos da revolução e a redação de uma nova Constituição. Para este autor, a Assembleia

\footnotetext{
${ }^{42}$ Ver em Dicionário Crítico da Revolução Francesa, p. 522-523.

${ }^{43}$ Conferir em Dicionário Crítico da Revolução Francesa, p. 526.

${ }^{44}$ Ver em Dicionário Crítico da Revolução Francesa, p. 535.
} 
Nacional nasceu antes da revolução, seus representantes estavam mais ligados ao Antigo Regime. Ela consistia ainda, apesar da mudança do nome, na antiga instituição dos Estados Gerais. ${ }^{45}$ Nessa perspectiva, a Assembleia Nacional jamais conseguiria ter rompido com a coroa e criar novas leis fundamentais sem as demandas das Assembleias de Eleitores que eram enviadas ao órgão central por meio da imprensa e de cartas e sem as marchas que levaram o povo às ruas. ${ }^{46}$

Nesse sentido, parece que Baker aceita o argumento que foi vencedor na Assembleia Nacional ao cabo do debate constitucional, de que a política deve ser restrita aos representantes. Não é raro atualmente este tipo de análise que foca nas instituições representativas e se esquece das ações extraparlamentares.

\section{$\underline{\text { Revisão teórica das revoluções }}$}

Bernard Manin, no capítulo mais discutido de seu livro Princípios do Governo Representativo, ${ }^{47}$ trata do princípio de distinção como uma das principais inovações da Revolução Americana. O princípio da distinção consiste na concepção de que os representantes são superiores que seus eleitores, são cidadãos mais eminentes. Nesse sentido, o governo representativo possui uma característica desigualitária, os eleitos são de posição social mais elevada que seus eleitores. ${ }^{48}$

Para Manin, o princípio de distinção foi abertamente defendido somente na Revolução Americana, embora, nas Revoluções Inglesa e Francesa, regras que garantiam a distinção entre eleitores e eleitos foram instituídas. Além disso, no Novo Mundo, este princípio foi estabelecido por meio de arranjos institucionais que não se baseavam em privilégios ou costumes.

Segundo o autor, na Inglaterra, a lei de 1710 para eleição na Câmara dos Comuns exigia certo nível de renda para votar, e, para ser membro do Parlamento, as exigências de

\footnotetext{
${ }^{45}$ Ver em História da Revolução Francesa, p. 237.

${ }^{46}$ Sobre a comunicação dos cidadãos em assembleias e a relação entre os Estados Gerais e Assembleia Nacional, conferir em História da Revolução Francesa, p. 107 e 141.

${ }^{47}$ Livro publicado em 1997. Tradução do capítulo "O princípio da distinção" está na Revista Brasileira de Ciência Política, $\mathrm{n}^{\circ}$ 4, ano 2010.

${ }^{48}$ Ver em "O princípio da distinção", p. 187-188.
} 
propriedade e renda eram ainda maiores. ${ }^{49}$ Havia, portanto, uma restrição adicional aos representantes. Já na França, o direito de voto em 1789 se tornou mais amplo. Mesmo assim, também foi criada restrição por renda e propriedade para os representantes. $\mathrm{O}$ argumento que sustentava a restrição do voto era de que os pobres dependiam de outras pessoas e por isso não teriam vontade política própria. Ainda foi estabelecido um sistema de eleição indireta que consistiu em um mecanismo de filtragem para assegurar que os representantes fossem cidadãos proeminentes: as assembleias primárias votavam em eleitores que, por sua vez, votavam nos deputados. Em 1792, com a instituição do voto universal masculino, foi abolida a restrição por renda nas assembleias primárias, mas foi mantida a eleição indireta e a restrição de renda para os eleitores de segundo estágio. Com isso, aqueles que votavam nos delegados pertenciam às classes ricas. ${ }^{50}$

Nos Estados Unidos, na Conferência da Filadélfia, o debate maior se deu em torno das eleições para a Câmara Federal. A exigência para o direito de voto ficou a cargo das constituições estaduais. Com relação aos candidatos a deputado federal, a Carta Constitucional dizia pouco: exigia-se que o candidato fosse maior de vinte e cinco anos e que habitasse pelo menos sete anos no estado pelo qual concorria à eleição. Para Manin, esta norma parece ser muito democrática, uma vez que não restringe por renda a elegibilidade. Entretanto, ao observar os debates na Convenção da Filadélfia, o autor conclui que não foi possível estabelecer um critério de renda e propriedade nacional em razão das diferenças econômicas entre o norte - mais industrializado - e o sul, que contava com grandes propriedades rurais.

Os debates na América do Norte se centraram então no princípio da representação e nos arranjos e mecanismos eleitorais correspondentes a este princípio. Resumidamente falando, os antifederalistas defenderam a teoria do mandato: a tarefa do representante seria espelhar as opiniões daqueles que representa e para isso os representantes deveriam ser similares aos representados, ou seja, o legislativo deveria ser composto pelos principais componentes da sociedade: proprietários de terras, artesãos, comerciantes. ${ }^{51}$

\footnotetext{
${ }^{49}$ Conferir em "O princípio da distinção”, p. 190.

${ }^{50}$ Conferir em "O princípio da distinção", p. 192-194.

${ }^{51}$ Os argumentos dos antifederalistas podem ser encontrados em "O princípio da distinção", p. 203-205.
} 
Os federalistas, ao contrário, defendiam que os representantes deveriam ser diferentes de seus eleitores. Os representantes seriam eleitos justamente por se mostrarem mais sábios e virtuosos. Eles formariam uma aristocracia natural que se destaca do povo não por hereditariedade, títulos ou privilégios, como na aristocracia europeia, mas por suas qualidades superiores. Nessa perspectiva, os representantes não deveriam espelhar as opiniões do povo, mas agir de acordo com seus próprios julgamentos e em interesse de seus eleitores. ${ }^{52}$

Para colocar em prática o princípio de distinção, era preciso criar um arranjo eleitoral que favorecesse a escolha dos melhores e, além disso, que evitasse que os representantes se corrompessem. As eleições frequentes - a cada dois anos - foram defendidas como uma arma para manter representantes virtuosos e próximos aos eleitores: quem se corrompesse não seria eleito novamente. Além disso, desenhou-se um distrito eleitoral grande, uma vez que se alegava que um maior número de eleitores dificilmente cairia nas garras de demagogos e facções. Um eleitorado vasto dificultaria a influência da riqueza. Nesse sentido, os federalistas defenderam que o método eleitoral é capaz de criar uma aristocracia sem que haja privilégios e títulos de nobreza, isto é, que eleições podem produzir um efeito aristocrático.

O que Manin nos indica é que a Constituição Americana, por meio de certas regras eleitorais, foi capaz de reduzir o âmbito da ação para poucos escolhidos e ao mesmo tempo conseguiu estabilidade. ${ }^{53}$

No contexto atual, a Revolução Americana ganha destaque por ter produzido um corpo político estável por meio da representação, enquanto que a experiência da Revolução Francesa é desvalorizada em razão da Assembleia Nacional não ter sido capaz de criar uma Constituição duradoura e os órgãos populares serem entendidos como parte da máquina do terror. É possível notar que, embora estes dois eventos tenham ocorrido há mais de 200 anos, ainda são contemporâneos na medida em que sua interpretação está ligada ao presente: os princípios da democracia representativa e outras questões políticas são atrelados às Revoluções Americana e Francesa. Nesse sentido, recuperar o pensamento

\footnotetext{
52 Já os argumentos dos federalistas favoráveis ao princípio de distinção podem ser encontrados em "O princípio da distinção", p. 209-210.

${ }^{53}$ Conferir em "O princípio da distinção", p. 224.
} 
arendtiano com relação aos problemas apontados na representação, no sistema partidário, entre outros, e às possibilidades perdidas da revolução, notadamente a participação ampliada, pode auxiliar na reflexão de nosso tempo. Para dizer de outra forma, as considerações da autora acerca de temas como a ação fundadora, seus riscos e sua potência, a tensão entre o político e o social e entre política ordinária e extraordinária ainda são heurísticas.

Levando isso em conta, este trabalho procura tratar das categorias mobilizadas em Sobre a Revolução sem subordiná-las à revisão histórica e teórica das Revoluções Francesa e Americana. Alguns dos comentários mais influentes sobre o pensamento de Arendt parecem estar apoiados nesta reinterpretação das revoluções do século XVIII, pois pouco falam da ação fora das instituições parlamentares, entendem o sistema de conselhos como metáfora e apontam Arendt como crítica da Revolução no Velho Mundo e defensora da revolução no Novo Mundo.

Ao contrário, buscaremos mostrar aqui que a comparação entre as duas experiências revolucionárias é a base das reflexões de Arendt, de forma que as semelhanças, diferenças, novidades, sucessos e fracassos de ambas as experiências são igualmente importantes para as considerações sobre a política. Além disso, procuraremos ressaltar a historicidade das categorias políticas arendtianas, isto é, apontar sua origem na Antiguidade e o deslocamento dos conceitos na Modernidade. Na medida em que a literatura sobre o pensamento da autora já tratou suficientemente do procedimento de busca da origem dos conceitos - o qual é usado em outras obras, como A Condição Humana e Entre o Passado e o Futuro -, procurar-se-á esclarecer a historicidade dos conceitos na Modernidade que são explorados principalmente em Sobre a Revolução.

Em nossa perspectiva, a autora discute o deslocamento dos conceitos e traça a narrativa das revoluções principalmente por meio das ideias dos homens das revoluções. Nesse sentido, para Arendt, importam os fatos e também as ideias e princípios que adentraram o debate público e que levaram os homens à ação. É esta ênfase nas ideias e princípios dos revolucionários, sua relação com os fatos e com a historicidade dos conceitos políticos que denominamos de história dos conceitos. Como mencionado acima, esta tese buscará interpretar Sobre a Revolução como um tratado particular de história 
conceitual. Com esta interpretação esperamos reforçar o argumento de que Arendt é uma autora moderna e contribuir para a valorização de suas reflexões acerca das revoluções.

No primeiro capítulo, trataremos primeiramente da definição do conceito de revolução, o qual foi formulado por Arendt no debate com a tradição filosófica e por meio da investigação das mudanças nos seus usos. Em um segundo momento, apresentar-se-á a relação entre liberdade e revolução, bem como a mudança do significado do conceito de liberdade a partir das Revoluções Americana e Francesa. Por fim, trataremos do debate entre Arendt, Marx e a tradição revolucionária.

No segundo capítulo, trataremos do conceito de história em Arendt e da maneira como ela tece a narrativa sobre as Revoluções Americana e Francesa. Especificamente, apresentaremos as origens dos eventos revolucionários no século XVIII: a crise da autoridade, o gosto pela liberdade, a abertura de espaços públicos políticos por meio do debate e da resistência. Em seguida indicaremos o percurso e término destas revoluções por meio das concepções de suas figuras centrais.

No terceiro capítulo, trataremos das mudanças de significados dos conceitos de fundação, constituição, governo e representação. Discutiremos também a relação entre o sistema de conselhos e as novidades conceituais que as revoluções fizeram surgir a partir da narrativa da emergência e do desaparecimento dos conselhos em diversos levantes revolucionários.

Por fim, nas considerações finais, vincularemos os objetivos do livro Sobre a Revolução com a história conceitual. Além disso, retomaremos brevemente as mudanças nos principais conceitos políticos e procuraremos indicar a particularidade da história conceitual arendtiana. 


\section{Capítulo 1: Compreender a Revolução}

Hannah Arendt abre o livro Sobre a Revolução expondo as dificuldades de se compreender o mundo contemporâneo. No século XX, eventos inéditos, tais como, guerras travadas com o uso de armas de destruição em massa, revoluções que visavam libertar a humanidade de toda a opressão e o surgimento do totalitarismo, mostraram que as velhas formas de análise e categorias tradicionais não eram capazes de esclarecer ou explicar o que ocorria no mundo. Nos termos da autora, as novidades do século XX implicaram na ruptura com a tradição e, com isso, não fazia mais sentido aplicar aos fenômenos os velhos conceitos e modos de análise.

Além disso, para Arendt, a teoria política em seu tempo equivocava-se ao interpretar os eventos: por vezes, não distinguia um fenômeno de outro; amalgamava, por exemplo, guerra e revolução, violência e ação, liberdade e independência individual. Em geral, a teoria política dos anos de 1950 e 1960, segundo a autora, baseava suas análises em premissas que não eram capazes de tratar adequadamente as questões políticas, tais como as categorias de causa e efeito ou a noção de progresso histórico.

Neste contexto, Arendt aponta que o pensamento tradicional e algumas teorias de seu tempo mais obscureciam do que esclareciam os eventos políticos e que era preciso formular novos conceitos capazes de responder às questões mais importantes do século XX. Para tanto, ela volta sua reflexão para o século XVIII, quando as Revoluções 
Americana e Francesa inauguraram o mundo político moderno, redefiniram muitas categorias políticas e formularam princípios e modelos de ação para a posteridade.

A autora nota que no fim do século XVIII o termo revolução deixou de designar o retorno a uma forma constitucional conhecida para denotar a fundação de um corpo político inteiramente novo. Isto provocou um deslocamento em outras categorias, sobretudo, na concepção de liberdade, que, além de significar a participação nos assuntos públicos, passou a significar que os homens, por meio da ação fundadora, rompem com o curso dos acontecimentos e estabelecem um novo início na história.

Contudo, sua reflexão não se encerra com a recuperação da experiência revolucionária francesa e norte-americana. A autora apresenta e critica as interpretações das revoluções produzidas no século XIX com o objetivo de identificar as teorias que se tornaram hegemônicas e trouxeram problemas ao pensamento político contemporâneo.

Nesse sentido, Arendt desenvolve uma história do conceito de revolução que inicialmente analisa a dificuldade de compreender o presente e em, um segundo momento, retoma o passado para indicar a genealogia e a historia dos usos do termo revolução nos séculos XVIII, XIX e XX.

Em nossa interpretação, a autora, em Sobre a Revolução, descreve de certa forma uma reflexão circular em que o ponto de partida e de chegada é o presente. No início do livro, é explorada a dificuldade de compreensão dos principais eventos do século XX. Em um segundo momento, a autora indica a inadequação do pensamento de seu tempo e da tradição filosófica para analisar as revoluções ao recuperar os eventos revolucionários do século XVIII. Em seguida, ela argumenta que alguns pensadores do século XIX interpretaram mal estes eventos. Com isso, o leitor é levado a entender como tais interpretações influenciaram a teoria política e a ação no século XX.

Com o objetivo de melhor expor este movimento, a seguir articularemos os dois primeiros capítulos do livro dedicado às revoluções com outros textos da autora que tratam principalmente, da violência e do poder, do totalitarismo, da ruptura com a tradição, da compreensão, dos conceitos de liberdade e de ação e do conceito moderno de história. 


\subsection{Dilema do século XX}

Arendt na introdução do livro Sobre a Revolução aponta o dilema experimentado no século XX: o medo de uma guerra levar à aniquilação total do mundo e a esperança de que uma revolução pudesse emancipar a humanidade. Este medo surgiu com o aparecimento de armas de destruição em massa, já a esperança era inspirada nas ações em nome da liberdade que se tornaram recorrentes na história desde o fim do século XVIII.

Para a autora, o pensamento político se deparou com este dilema na medida em que tem como tarefa ajudar na compreensão do mundo contemporâneo. Especificamente, o pensamento político deve analisar e interpretar o significado da guerra e da revolução. No século $\mathrm{XX}$, os teóricos políticos tiveram como tarefa compreender diversos conflitos bélicos e agitações revolucionárias, notadamente, as duas Guerras Mundiais e as Revoluções Russa e Chinesa. Segundo Arendt, nesse contexto, guerra e revolução foram entendidas como fenômenos similares, de um lado, porque ambas justificam o uso da violência em nome da liberdade, por outro lado, em razão de algumas guerras terem desencadeado ou sucedido revoluções.

Entretanto, a autora nota que a guerra nem sempre foi relacionada com liberdade, ao passo que a revolução sempre esteve ligada a ela. De acordo com ela, o discurso destinado à defesa da guerra passou a recorrer à noção de liberdade no início do século $\mathrm{XX}$, quando a tecnologia bélica e a forma moderna de conflito armado mostraram seu alto potencial de destruição: a partir da I Guerra Mundial, a diferença entre soldados e civis deixou de ser respeitada e a derrota passou a significar o fim do governo, do Estado e até mesmo a aniquilação total de um povo. Além disso, após a II Guerra Mundial, a corrida armamentista se converteu em um ensaio de guerra em que se exibia ao adversário a potência de destruição total que se possui. No contexto do século XX, as guerras passaram a ser travadas de forma diferente e o desenvolvimento da tecnologia bélica - o qual passou a possibilitar a aniquilação de toda a humanidade - tornou a guerra um recurso quase injustificável. ${ }^{1}$ Para dizer de outra forma, o desenvolvimento técnico da violência alcançou tal ponto de potencial destrutivo que passou a ser difícil conceber um objetivo que pudesse

\footnotetext{
1 Ver em Sobre a Revolução, p. 39-41.
} 
ser articulado com este potencial. Segundo a autora, o único argumento que poderia ser aceitável em favor do uso de tamanho potencial de violência seria o de proteger ou de garantir a liberdade e a sobrevivência de uma comunidade. E mesmo assim, seria necessário argumentar que o aparato bélico usado em prol da liberdade e da sobrevivência consistiria no menos letal e mais restrito disponível, caso contrário, a sobrevivência de muitos e, por consequência, a liberdade estariam em risco.

Já o discurso revolucionário, desde a primeira revolução, clamava pela liberdade. A frase de Condorcet "A palavra revolucionário só pode ser aplicada a revoluções cujo objetivo é a liberdade" (Sobre a Revolução, p. 56) afirma esta ligação entre ação revolucionária e liberdade. Aqui, ao mostrar que o discurso revolucionário, diferente do discurso de justificação da guerra, sempre esteve relacionado com liberdade, Arendt apresenta um dos principais conceitos relacionados a este fenômeno: os eventos revolucionários, embora tenham envolvido guerras e o uso de violência, estão intimamente relacionados à emancipação e à liberdade.

"Porém, por mais necessário que seja distinguir na teoria e na prática entre guerra e revolução, apesar da íntima relação entre elas, não podemos deixar de notar que o simples fato de ser inconcebível qualquer guerra ou revolução fora do campo da violência é suficiente para distingui-las de todos os outros fenômenos políticos. Seria difícil negar que uma das razões pelas quais as guerras se convertem tão facilmente em revoluções e as revoluções têm mostrado essa sinistra tendência de desencadear guerras é que a violência constitui uma espécie de denominador comum a ambas". (Sobre a Revolução, p. 44)

Para entender como a violência é empregada nestes dois fenômenos, Arendt procura as origens de cada um. A guerra é um fenômeno antigo, está tradicionalmente ligada ao conflito entre duas ou mais cidades e se prestava à garantia dos interesses de cada cidade. As palavras de Tito Lívio mostram, de acordo com a autora, que as guerras, além de serem fenômenos antigos, não foram empregadas somente em nome da liberdade: "É justa a guerra que é necessária, e sagradas são as armas quando não há esperança senão nelas" (Sobre a Revolução, p. 37).

A revolução surgiu apenas na Modernidade, e quando há o recurso à violência, esta geralmente ocorre dentro das fronteiras de uma comunidade política e está relacionada com a libertação da opressão. Na Idade Antiga, a guerra não era entendida como um fenômeno político, uma vez que a política estava relacionada ao debate e deliberação, à fala e à 
persuasão que ocorria dentro da polis, dizia respeito à liberdade e à isonomia dos cidadãos. A guerra se desenrolava fora dos muros da cidade, envolvia duas ou mais cidades que se relacionavam principalmente por meio da violência e da força, não pelo debate.

No intuito de comprovar que dentro do espaço público nas cidades antigas os cidadãos se relacionavam por meio do discurso e excluíam os meios de violência, a autora menciona o costume ateniense de persuadir ao invés de obrigar o condenado à morte a tomar cicuta. ${ }^{2}$ A este exemplo se pode acrescentar a experiência da República romana, onde o exército não podia adentrar os muros de Roma, pois os romanos deveriam ocupar a cidade como cidadãos, não como soldados.

Levando isso em conta, a autora se depara com mais três diferenciações entre guerra e revolução, a saber, a época em que elas apareceram pela primeira vez, o lugar a que elas pertencem - as guerras fora do corpo político, e a revolução dentro do corpo político -, e em nome de que a violência é empregada.

Nessa perspectiva, a violência tem um caráter instrumental. Como qualquer outro instrumento, ela consiste em um meio para alcançar um fim, portanto, deve ser usada de uma forma tal que garanta que o fim seja alcançado. Quando a violência é empregada em nome de uma proposta política, como liberdade ou autonomia, deve ser justificada e ter limitada a forma de seu uso por meio de debate público. Em outras palavras, a violência não é política, mas a justificação de seu uso pode se tornar uma questão política.

Para a autora, um levante revolucionário mesmo que recorra à violência, não deve ser determinado por ela: a violência pode ser empregada para derrubar um governo que oprimia e dominava o povo, mas uma revolução não se resume à derrubada de um governo arbitrário, sobretudo, consiste na fundação de um novo corpo político. Conforme Arendt, a violência consiste em uso de artefatos e instrumentos que aumentam o vigor corporal e, no último estágio de seu desenvolvimento, tais instrumentos e artefatos substituem o vigor físico. ${ }^{3}$ Para a autora, a violência força aqueles que são submetidos a ela a obedecer: aquele que está sob a mira de uma arma será obrigado à cumprir ordens. Por exemplo, ao ser aplicada em uma revolução, força os governantes a desistirem de seus cargos públicos. Assim, onde a violência é usada não há debate público, troca de opiniões e escolhas, mas

\footnotetext{
${ }^{2}$ Ver em Sobre a Revolução, p. 37.

${ }^{3}$ Ver Sobre a Violência, p. 63.
} 
reina o silêncio e obediência. Em suas palavras: "Onde ela impera absoluta (...) tudo e todos devem quedar em silêncio. É por causa desse silêncio que a violência é um fenômeno marginal na esfera política; pois o homem, como ser político, é dotado de fala" (Sobre a Revolução, p. 44).

Levando isso em conta, a violência consiste em um elemento marginal na revolução, que pode apenas auxiliar na destruição do antigo governo. Os instrumentos de violência são capazes de destruir, contudo, eles não têm capacidade criadora. ${ }^{4}$ Somente o poder pode criar algo novo.

Segundo Arendt, a dificuldade de entender o papel marginal da violência na revolução vem da indistinção entre poder e violência presente na teoria política. Para ela, há um "consenso entre os teóricos da política, da esquerda à direita, no sentido de que a violência é tão somente a mais flagrante manifestação de poder" (Sobre a Violência, p. 51). Nesta concepção, poder e violência teriam a mesma função: colocar alguém no comando e gerar obediência. ${ }^{5}$ Contudo, no pensamento arendtiano, a violência impõe a obediência pela força, o poder, de modo distinto, é fruto do apoio. Ainda, a violência tem capacidade de impedir ou destruir coisas, ao contrário, o poder pode colocar coisas em movimento e criar algo novo.

De acordo com ela, o poder consiste em um potencial de realizar algo no mundo, ele só existe quando os homens agem em conjunto. ${ }^{6}$ A condição de existência de poder é o espaço da aparência onde os homens possam se inter-relacionar por meio do discurso e da ação. Somente neste espaço em que é possível a troca de opiniões e de diferentes perspectivas os homens podem escolher um princípio de ação compartilhado e se associar para mudar o mundo ${ }^{7}$ e para iniciar algo novo. Somente neste espaço os homens podem apoiar uma ação, isto é, dar seu consentimento para que ela continue ou agir para sustentála. O poder, distintamente dos instrumentos de violência, não pode ser propriedade de um

\footnotetext{
${ }^{4}$ Bernstein bem observa que Arendt não trata de outros tipos de violência, como, por exemplo, violência relacionada à religião, aos crimes comuns, ao terrorismo. Ver em Violence: Thinking without Banisters, p. 99. A Autora está preocupada com o tipo de violência que adentra no espaço público, é justificada por argumentos políticos e nomeada como poder de um grupo.

${ }^{5}$ Conferir em Sobre a Violência, p. 59.

${ }^{6}$ Ver A Condição Humana, p. 250.

${ }^{7}$ De acordo com Arendt, o mundo não é o mesmo que Terra, ambiente natural. O mundo é criado pelos homens por meio de coisas, palavras e artefatos culturais. Assim, o mundo é o lugar que abriga os homens e, ao mesmo tempo, é assunto dos homens. Conferir em A Condição Humana, p. 254.
} 
homem, ele só existe quando e enquanto um grupo de homens se mantém unido. Somente no espaço público surge o apoio que é capaz de conferir poder ao agente, que não está sozinho, mas age em nome de um grupo. Nesse sentido, o poder está fundamentado no apoio de um grupo. Quando aquele que foi empossado do poder perde este apoio, ele perde o poder.

Dessa forma, no momento em que um povo deixa de apoiar o governo, suas leis e instituições, este governo perde o poder. Arendt distingue dissidência de resistência, o primeiro diz respeito ao ato pelo qual um povo ou grupo retira publicamente seu apoio a uma lei ou a um ato do governo, já a resistência consiste no questionamento da autoridade e de todo o conjunto de instituições e leis, ela implica rejeitar a autoridade e legitimidade dos ocupantes dos cargos públicos, do sistema de leis ou da forma constitucional. Nesse sentido, resistência é diferente de oposição e dissidência. Estas últimas envolvem uma espécie de assentimento ao governo, às leis e instituições em geral. $\mathrm{O}$ assentimento envolve o direito de divergir, pois para que o consentimento exista de fato é preciso que haja a possibilidade de recusar uma lei ou algo proposto pelo governo. ${ }^{8}$ Nesta perspectiva, a resistência, mais do que recusar um ato de governo, lei ou instituição, abala o reconhecimento das leis e de instituições e visa a tornar o governo impotente para agir. Para a autora, quando um governo perde o poder, só consegue manter sua existência por meio da violência: sem apoio do povo, a única alternativa é impor a obediência. Muitas revoluções foram precedidas pela perda de poder do governo e pelo uso da violência. Nestes casos, o antigo governo sempre foi derrubado pela resistência do povo e pela violência empregada por ele. Mas a constituição do novo corpo político nas revoluções só surgiu por meio do poder: com a reunião de homens que debatiam e agiam para criar uma nova forma de viver em comunidade.

Vale lembrar que, segundo Arendt, quando a violência ocupa todos os espaços, ela impede o debate e a ação. A violência não destrói a política quando ela é limitada e está fora do espaço público. Para ilustrar esta afirmação, a autora dá o exemplo da deliberação sobre a guerra: esta deliberação e o debate público que a envolve são políticos, mas a guerra em si, as batalhas e o uso das armas não. Assim, pode-se relacionar violência e

\footnotetext{
${ }^{8}$ Arendt mostra que a dissidência pode se tornar resistência em emergências políticas, isto é quando as instituições e ordenamentos deixam de funcionar adequadamente. Conferir em "Desobediência Civil", p. 90.
} 
revolução apenas quando os meios violentos são empregados para libertar os homens da opressão, com o objetivo de fundar um espaço político livre, quando são usados para permitir a constituição de um novo corpo político. Dito de outra forma, um dos elementos da revolução é a violência, porém este é um elemento marginal e limitado. A violência não pode ocupar todos os espaços, deve ser restrita para que o debate e a fundação de um novo corpo político sejam possíveis. Na Revolução Americana, por exemplo, a violência foi restrita ao combate contra os ingleses, os homens deixavam as armas de lado quando se tratava de decidir em conjunto sobre a independência e debater sobre a criação de um novo corpo político.

A autora se preocupa com a questão da destruição do espaço político pela violência em razão do surgimento do totalitarismo no século $X X$, regime em que a violência se transformou em terror: tornou-se a essência do governo. Para ela, o ápice do terror se deu quando todo o poder foi entendido como ameaçador e, já tendo aniquilado a oposição, o regime passou a perseguir seus apoiadores. ${ }^{9}$ De acordo com Arendt, o terror no totalitarismo tem o papel de minar a ação humana espontânea: pressiona os homens uns contra os outros de maneira que suprimi o espaço entre eles. ${ }^{10}$ Tal espaço permite a atividade política, o debate público e a ação em conjunto. Além de destruir as relações políticas, o terror visa a produzir a desolação, isto é, arruinar todas as relações entre os homens: vínculos públicos, privados e, em última instância, acabar com a relação dos homens com eles mesmos. Em outras palavras, o terror tem o objetivo de inviabilizar o debate público, o diálogo entre amigos e até mesmo o diálogo interior. ${ }^{11}$

Se, por um lado, a autora indica que a violência tende a ameaçar a atividade política onde quer que ela seja empregada, por outro, Arendt mostra que a ação livre tem a potência de colocar fim à dominação, mesmo que seja a dominação totalitária: no último parágrafo de Origens do Totalitarismo encontramos a afirmação sobre a potência da liberdade humana entendida como a capacidade de começar algo novo.

\footnotetext{
${ }^{9}$ Sobre a Violência, p.73.

${ }^{10}$ Ver sobre terror em Origens do Totalitarismo, p. 517-519.

${ }^{11}$ Conferir em Origens do Totalitarismo, p. 526-527. A afirmação de Arendt de que no totalitarismo as relações privadas são fortemente ameaçadas foi melhor ilustrada, ao meu ver, na cena "O Espião" da peça de Brecht intitulada Terror e Miséria no Terceiro Reich. A cena mostra um casal apavorado com a possibilidade de que próprio filho os tenha denunciado à Gestapo (polícia política) por motivo de algum comentário depreciativo sobre a situação na Alemanha. Nesse sentido, é possível ver que a relação entre marido e mulher e entre pais e filho é perpassada pela desconfiança e pelo medo.
} 
"O começo antes de tornar-se um evento histórico, é a suprema capacidade do homem; politicamente, equivale à liberdade do homem. Initium ut esset homo creatus est - 'o homem foi criado para que houvesse um começo', disse Agostinho. Cada novo nascimento garante esse começo; ele é, na verdade, cada um de nós" (Origens do Totalitarismo, p.531).

Segundo Bignotto, esta afirmação não deve ser lida como uma confiança otimista na potencialidade do homem de iniciar. Tal leitura seria contraditória com a vigorosa exposição acerca da radicalidade e da novidade das experiências totalitárias nos parágrafos precedentes do livro. Para o autor, Arendt indicou nesta passagem que os limites do totalitarismo estão na ação fundadora:

"O ato que transforma um regime totalitário em um mundo político só pode ser, a nosso ver, um ato de fundação, que ocorre independentemente das condições anteriores ao momento em que ele acontece e que só depende de uma característica do ser humano que nomeamos, a justo título, liberdade" (Bignotto, "Totalitarismo e liberdade no pensamento de Hannah Arendt", p. 119).

Neste ponto, nos deparamos com um impasse teórico: se o totalitarismo tende a arrastar os homens para a desolação e acaba com o contato público e privado entre eles, como é possível a ação fundadora? Como os homens podem se articular politicamente para instaurar o novo onde o terror e a desolação vigoram?

Teoricamente falando, este impasse não pode ser desfeito. Por um lado, a autora liga nascimento com início, afirma que há a possibilidade de um novo começo mesmo em tempos sombrios. Ainda, quando trata das revoluções, ela relaciona liberdade e fundação, e afirma a potência da ação de romper com os acontecimentos e regime precedentes para constituir algo novo. Por outro lado, descreve o totalitarismo como um regime que domina o espaço público, acaba com a liberdade e a espontaneidade.

Contudo, quando Arendt trata de alguns eventos históricos, indica algumas possibilidades de resolução deste impasse. A possibilidade do surgimento da liberdade em tempos sombrios não consiste em otimismo ou utopia, mas está baseada nas experiências do século XVIII e XX: as Revoluções Americana e Francesa mostraram que a ação tem a potência de fundar o novo independentemente das condições anteriores, e a Revolução Húngara, a Resistência Francesa e o movimento Rosa Branca mostraram que é possível a ação em conjunto [acting together] mesmo sob ditadura ou totalitarismo.

Para Arendt, a Revolução Húngara consistiu em um levante espontâneo e inesperado do povo, o qual foi iniciado e levado a cabo por muitos, não foi guiado por um 
líder ou partido e não recorreu à força militar ou às técnicas de golpe de Estado. ${ }^{12}$ Já a Resistência Francesa constituiu um espaço público clandestino que tratava dos problemas relevantes da França em um contexto de ocupação totalitária e de vácuo de poder nas instituições do país. ${ }^{13}$ O movimento Rosa Branca, que durou de junho de 1942 a fevereiro de 1943, distribuía panfletos pelo correio e na Universidade de Munique. Tais panfletos acusavam Hitler de assassinato em massa e conclamavam o povo alemão a lutar contra o nazismo. $^{14}$

Levando isso em conta, entendemos que no pensamento da autora os regimes totalitários e as revoluções são os eventos centrais a partir dos quais ela discute os principais conceitos da teoria política, tais como violência, dominação, poder, resistência, liberdade.

De acordo com Arendt, uma vez que estes eventos foram inéditos e introduziram novidades no mundo, para compreendê-los é preciso formular novos conceitos. Em outras palavras, as revoluções do século XVIII contribuíram para a crise da tradição; e o surgimento do totalitarismo, para a ruptura com a tradição.

\footnotetext{
${ }^{12}$ Nas palavras da autora: "Se houve alguma vez algo como a 'revolução espontânea' de Rosa Luxemburgo este inesperado levante de um povo oprimido em nome da liberdade e de quase mais nada, sem o desmoralizante caos da derrota militar o precedendo, sem técnicas de golpe de Estado, sem a debilitante propaganda de um partido revolucionário, isto é, algo que todo mundo - conservadores e liberais, radicais e revolucionários - havia descartado como um sonho nobre - nessa ocasião, nós tivemos o privilégio de testemunhar isto". No original: "If there was ever such a thing as Rosa Luxembur's 'spontaneous revolution' this sudden uprising of an oppressed people for the sake of freedom and hardly anything else, without the demoralizing chaos of military defeat preceding it, without coup d'état techniques, without the undermining propaganda of a revolutionary party, something, that is, which everybody, conservatives an liberals, radicals and revolutionists, had discarded as a noble dream - then we had the privilege to witness it". (Arendt, H. "Totalitarian Imperialism: Reflections on the Hungarian Revolution", p. 8. Artigo sem edição em português).

${ }^{13}$ Conferir em Entre o Passado e o Futuro, p. 29-30.

${ }^{14}$ Arendt menciona o movimento Rosa Branca ao mostrar que os irmãos Scholl foram os únicos que conseguiram romper o isolamento e a desolação ao se manifestarem publicamente (Eichmann em Jerusalém, p. 120). Sobre o conteúdo dos panfletos deste movimento conferir em http://www.whiterosesociety.org/WRS pamphlets home.html. Último acesso em 15 de outubro de 2015.
} 
Para a autora, a tradição do pensamento ocidental começou com os romanos quando eles decidiram adotar o pensamento e a cultura grega como guia. ${ }^{15}$

"Antes dos romanos, desconhecia-se algo que fosse comparável à tradição; com eles ela veio, e após eles permaneceu o fio condutor através do passado e a cadeia à qual cada nova geração, intencionalmente ou não, ligava-se em sua compreensão de mundo e em sua própria experiência" (Entre o Passado e o Futuro, p. 53).

Nessa perspectiva, tradição consiste numa espécie de fio que liga os homens do presente a determinados fatos, coisas e pensamentos do passado. Ela indica quais acontecimentos, obras e conceitos são relevantes, aponta o que deve ser conhecido e o que deve guiar a ação e a compreensão dos homens do presente.

Ao adotar o pensamento grego, os romanos elegeram como modelo a filosofia de Platão e Aristóteles. Assim, a tradição filosófica começou com Platão. De acordo com Arendt, a filosofia política foi marcada pela alegoria da caverna, em que o mundo comum, ou seja, o convívio entre os homens, é entendido como obscuro, confuso e ilusório, e para alcançar a verdade seria preciso abandonar tal esfera e contemplar o céu límpido onde é possível encontrar as ideias claras e eternas. ${ }^{16}$ Ao voltar para a caverna, aquele que encontrou a verdade tenta impô-la ao mundo comum. Assim, a tradição do pensamento político começou com o distanciamento da filosofia em relação à vida política. Nas palavras de Arendt, "A Filosofia Política implica necessariamente a atitude do filósofo para com a Política; sua tradição iniciou-se com o abandono da Política por parte do filósofo, e o subseqüente retorno deste para impor seus padrões aos assuntos humanos" (Entre o passado e o futuro, p. 44). ${ }^{17}$

\footnotetext{
${ }^{15}$ Exemplos da decisão dos romanos de se ligarem ao pensamento e cultura gregos podem ser encontrados, por exemplo, no livro de Cícero, De Republica, parágrafos 18 e 19 do Livro II, onde o autor afirma que Roma foi fundada em tempos doutos: muito depois de Homero, a Grécia já estava repleta de poetas e músicas, depois que Licurgo, fundador de Esparta, já tinha escrito as leis. Esse saber que surgiu na Grécia deu ocasião para que Roma fosse fundada de maneira excelente. Ainda, Tito Lívio, historiador romano, se autonomeou herdeiro de Tucídides.

${ }^{16}$ Conferir interpretação de Arendt sobre o mito da caverna de Platão em Entre o Passado e o Futuro, p. 64.

${ }^{17}$ Arendt aponta aqui a diferença entre falar com a cidade e falar para a cidade. No primeiro caso, a cidade é assunto de debate entre o filósofo e seus concidadãos, já no segundo, trata-se de convencer os cidadãos a adotarem uma doutrina filosófica para governar a cidade.
} 
O fim da tradição veio com a declaração de Marx de que a verdade não está localizada no mundo das ideias, mas na atividade humana do trabalho, principal elemento de sua filosofia. Por meio do conceito de trabalho ele interpreta a história, a diferença entre o homem e outros animais e a relação entre os homens. Assim, Marx inverteu o lugar onde era possível encontrar a verdade e inverteu também a tradicional hierarquia entre a vida contemplativa e a vida ativa. Na Antiguidade, a vida contemplativa e a ação política, a participação nos negócios da polis, eram consideradas as capacidades humanas mais importantes. O trabalho, a atividade que garante a subsistência que é capaz de produzir bens de consumo, e a fabricação de instrumentos e coisas, que produz bens duráveis e obras de arte, eram mais desvalorizadas. Segundo Arendt, ao colocar o trabalho como centro de sua teoria, Marx se rebela contra o pensamento tradicional. ${ }^{18}$

Arendt entende a rebelião de Marx contra a tradição como uma grandeza de seu pensamento, pois ele foi capaz de perceber que a tradição não era mais capaz de lidar com alguns problemas de seu tempo. Em outras palavras, Marx se deu conta de que a tradição estava se esgarçando e que era preciso formular outros conceitos para responder às perplexidades da modernidade.

Apesar de afirmar que o pensamento do século XIX marcou o início da derrocada da tradição, Arendt destaca que a perda completa da tradição ocorreu somente no século XX. Em suas palavras:

"Contudo, nem as consequências no século XX nem a rebelião do século XIX contra a tradição provocaram efetivamente a quebra em nossa história. (...) A dominação totalitária como um fato estabelecido, que em seu ineditismo não pode ser compreendida mediante as categorias usuais do pensamento político, e cujos 'crimes' não podem ser julgados por padrões morais tradicionais ou punidos dentro do quadro de referência legal de nossa civilização, quebrou a continuidade da História Ocidental. A ruptura em nossa tradição é agora um fato acabado". (Entre o Passado e o Futuro, p. 53).

Com a perda da tradição, dois problemas surgiram: primeiro, a reflexão sobre o mundo se tornou mais difícil sem os conceitos tradicionais que constituíam um guia, uma espécie de corrimão em que o pensamento se apoiava; segundo, os acontecimentos passados correm o risco de serem esquecidos, uma vez que a tradição também consistia em um fio que guiava os homens do presente até o passado e o resguardava. Sem ela, as

\footnotetext{
${ }^{18}$ Conferir em Entre o Passado e o Futuro, p. 43-49.
} 
grandes experiências e feitos humanos podem ser desprezados por não existir nada que indique seu valor. ${ }^{19}$ No que concerne à interpretação das revoluções, a crise da tradição pode, por um lado, gerar a irreflexão sobre estes eventos ou a incompreensão da novidade que eles engendraram, por outro lado, pode causar o esquecimento da experiência revolucionária.

Neste contexto de ruptura com a tradição, em que as categorias e a forma de análise tradicional não são suficientes, Arendt encontrou dois procedimentos para compreender os eventos políticos: um deles consiste no questionamento dos conceitos tradicionais, na exposição da incapacidade destes em dar conta das revoluções e regimes totalitários. $\mathrm{O}$ outro consiste na recuperação do passado por meio da origem dos termos e na investigação da historicidade dos termos na Modernidade. Estes procedimentos se tornam essenciais quando não se pode compreender o presente e recuperar o passado por meio do fio da tradição.

O primeiro procedimento consiste em pensar os conceitos tradicionais. Para Arendt, "Na prática, pensar significa que temos que tomar novas decisões cada vez que somos confrontados com alguma dificuldade" ( $A$ Vida do Espírito, p. 133). Tais dificuldades são encontradas quando algum evento faz surgir algo novo no mundo que gera perplexidade, pois as regras e conceitos pré-existentes não podem ser aplicados. ${ }^{20}$

Segundo a autora, o pensar consiste em um diálogo interior. Antes de conversar comigo mesmo, converso com os outros e descubro que o diálogo dentro de mim também é possível: o eu é capaz de se dividir em dois a fim de perguntar e responder a si mesmo. A partir deste diálogo, o pensamento tem a potência de contestar as pré-concepções de forma a derrubá-las ou deslocá-las. Na perspectiva arendtiana, Sócrates é a figura chave para tratar da faculdade do pensamento. Este pensador travava diálogos com seus concidadãos e questionava de tal forma as pré-concepções de seus interlocutores acerca de categorias cotidianas como justiça, felicidade, coragem, entre outros, que as dissolviam. Na medida em que o diálogo se desenrolava, nada ficava no lugar, tudo se movia.

\footnotetext{
${ }^{19}$ A perda da tradição, além dos problemas enunciados acima, pode gerar também uma oportunidade, a saber, olhar para o passado sem usar a lente da tradição. Isso possibilita descobrir acontecimentos e ideias que não eram valorizados pelo pensamento tradicional.

${ }^{20}$ De acordo com Lefort, para Arendt, “"pensar' não significa simplesmente mover-se no já pensado, mas recomeçar e, precisamente, recomeçar através das provações impostas pelo acontecimento". Em "Hannah Arendt e a questão do político", p. 65.
} 
Para ilustrar o efeito do pensamento, Sócrates usou a metáfora do vento. O vento é invisível, mas os deslocamentos que provoca são visíveis para todos. O vento e o questionamento do pensamento não são vistos, mas ambos tiram as coisas do lugar, movem o que era fixo e estável. ${ }^{21}$ Nesse contexto, o pensamento tem a potência de derrubar ou mover as pré-concepções.

De acordo com Arendt, é comum buscar nas categorias tradicionais, nos conceitos formulados no passado, elementos para entender o presente. Este procedimento de avaliar o presente por meio das concepções tradicionais podia ser profícuo e adequado até o século XVIII, quando as velhas categorias do pensamento político deixaram de responder algumas questões em razão das mudanças causadas pela Revolução Industrial e pelas Revoluções Americana e Francesa. A partir do século XX, a originalidade do totalitarismo terminou de demolir nossas conhecidas e velhas categorias do pensamento. Nas palavras da autora: "A ruptura totalitária nos privou dos elementos tradicionais de compreensão" (Arendt: Compreender formação, exílio e totalitarismo, p. 337). ${ }^{22}$ Esse fracasso pode ser visto, por exemplo, nos Julgamentos de Nuremberg: as categorias do direito, as tipificações criminais e penas não eram aplicáveis à monstruosidade dos crimes cometidos durante o nazismo. A categoria de homicídio não servia para julgar adequadamente os assassinatos em massa que ocorriam nos campos de concentração e extermínio, era preciso criar novas categorias do direito para lidar com os crimes do totalitarismo.

Sem o auxílio dos conceitos e da forma de reflexão tradicionais, estes eventos podem ser mal compreendidos e o mundo pode ser considerado um lugar estranho e inóspito. $\mathrm{Na}$ perspectiva de Arendt, compreender consiste em buscar o significado dos eventos para que os homens não se retirem do mundo, para que eles estejam à vontade no mundo, sintam o mundo como sua casa, seu lugar [be at home in the world]: "O resultado da compreensão é o significado a que damos origem no próprio processo de viver, na medida em que tentamos nos conciliar com o que fazemos e sofremos" (Arendt: Compreender formação, exílio e totalitarismo, p.331). Nesse sentido, a compreensão do

\footnotetext{
${ }^{21}$ Sobre Sócrates e o pensar, conferir em A vida do Espirito, p. 125-148.

${ }^{22} \mathrm{O}$ saber comum e os costumes foram herdados do passado. Com a ruptura totalitária, perdemos estas regras e conhecimentos comuns que apoiavam nossas ações e juízos no mundo. De acordo com Arendt, desde o começo do século XX, estamos perdidos no mundo mesmo seguindo as regras tradicionais. Isto quer dizer que o senso comum e costumes herdados do passado ainda existem, mas perderam seu sentido porque não conseguem mais nos orientar. Ver Arendt: Compreender formação, exílio e totalitarismo, p. 337.
} 
totalitarismo envolve entender como foi possível a dominação total para que o mundo não seja visto como um lugar inóspito, para que as pessoas possam agir dentro dele e evitar que tal regime apareça novamente.

Já a compreensão do significado de revolução envolve indagar quais novidades os eventos revolucionários introduziram no mundo e envolve discutir as possibilidades e os riscos da ação revolucionária. Nessa perspectiva, para estar à vontade no mundo, é preciso entender as potencialidades e perigos que as revoluções fizeram surgir no espaço público, refletindo sobre as novas relações e tensões entre violência e poder, dominação e libertação, constituição, lei e autoridade etc.

"Se a essência de toda ação, em particular da ação política, é dar um novo início, a compreensão se torna o outro lado da ação, a saber, aquela forma de cognição, distinta de muitas outras, por meio da qual os homens ativos (e não os homens que se dedicam a contemplar algum curso histórico progressivo ou fadado à decadência) finalmente vêm a aceitar o que aconteceu de maneira irrevogável e a se reconciliar com o que existe de modo inevitável" (Arendt: Compreender formação, exilio e totalitarismo, p. 345).

Esta citação, além de carregar uma crítica à filosofia da história, mostra uma distinção entre contemplar e compreender. Para Arendt, a contemplação e a filosofia, desde Platão, foram marcadas pelo distanciamento da vida pública; a compreensão, ao contrário, apesar de envolver as faculdades do espírito, não pode estar alheia ao que acontece no mundo, à ação e ao debate público. ${ }^{23}$

De maneira geral e resumida, a compreensão consiste em um processo complicado, uma atividade do espírito que envolve repensar ideias e conceitos do passado, refletir sobre os atos na esfera pública, e escolher dentre os conhecimentos científicos - isto é, as informações que a história, ciência política e outras áreas do conhecimento produzem quais podem lançar luz ao fenômeno para alcançar seu significado.

No intuito de compreender o significado do totalitarismo, Arendt lançou mão do procedimento de repensar os conceitos tradicionais no artigo "Compreensão e política". De acordo com a autora, os regimes nazista e stalinista foram, por vezes, classificados como

\footnotetext{
${ }^{23}$ Para Arendt, enquanto a filosofia política, forma de investigação carregada de elementos tradicionais, que separa pensar e agir e procura padrões externos à política para impor aos assuntos comuns - tais como verdade, bem supremo - a compreensão busca compreender as ações passadas a partir de elementos políticos e refletir sobre o mundo para que seja possível agir dentro dele. Nesse sentido, a autora afirma que há um certa tensão e inimizade entre o pensamento filosófico e a atividade política.
} 
uma espécie de tirania ou de ditadura. ${ }^{24}$ Contudo, para ela, ainda que, num primeiro olhar, estes regimes e um governo ditatorial ou tirânico tenham algumas características similares - todos acabam com a liberdade, impedem a participação livre nos assuntos da comunidade e usam da violência para se manterem -, eles não funcionam da mesma forma. Enquanto na ditadura e tirania as pessoas ficam restritas ao espaço privado e são impedidas de se engajarem nos assuntos públicos, no nazismo e stalinismo as massas foram constantemente mobilizadas no espaço público por meio da doutrinação e terror.

A autora diferencia esta mobilização das massas característica do movimento totalitário da ação política principalmente por meio da noção de pluralidade e de espaço entre os homens. ${ }^{25}$ A ação envolve um debate no qual diversos pontos de vista podem aparecer, isto é, uma pluralidade de opiniões e perspectivas é ouvida. Já no totalitarismo apenas um ponto de vista é publicizado - a ideologia totalitária - e apenas a voz do líder é propagada. Soma-se a isso a violência que joga e comprime uns contra os outros e o movimento característico dos regimes totalitários que destrói as leis e regras de convivência que têm a função de interligar as pessoas na esfera pública. Dessa forma, o espaço entre os homens é destruído. ${ }^{26}$ Além disso, nem o conceito de ditadura nem o de tirania explicam o tipo de violência que surgiu na Alemanha e na Rússia a partir da década de 1930: os campos de trabalho forçado, os campos de concentração, os expurgos do partido comunista, o genocídio em favor de uma raça pura eram coisas inéditas na história. Para entender como isso tudo foi possível era preciso formular novas categorias.

Nesse sentido, era preciso um novo conceito, e uma nova palavra - totalitarismo para tratar destes regimes. O procedimento inicial usado para formular a definição de

\footnotetext{
${ }^{24}$ Conferir em Arendt, "Compreensão e Política", em Compreender formação, exílio e totalitarismo, p. 334.

${ }^{25}$ Lefort chama a atenção para o fato de que a "ação" e o "discurso" no totalitarismo não têm ligação com a pluralidade humana, mas estão relacionados com a homogeneidade característica das massas. Além disso, ao considerar tudo como assunto público, a esfera política desaparece: "O que se chama ação não é ação quando não há atores. Isto é, quando não há iniciativas que se confrontam com situações inéditas, mas apenas uma decisão do chefe, decisão que se arroga como sendo efeito do movimento da história [lei absoluta do totalitarismo de esquerda] ou da vida [lei absoluta do nazismo], que recusa a contingência e que só exige de outrem comportamentos conformes às normas e às resoluções.

Igualmente, o que se chama 'fala' não é fala já que a fala não mais circula, já que desaparece todo vestígio de diálogo, já que um só, o Senhor absoluto, detém o poder de dizer, ao passo que todos estão reduzidos à função de ouvir e transmitir". Ver em "Hannah Arendt e a questão do político", p. 68.

${ }^{26}$ Origens do Totalitarismo, p. 526-527.
} 
totalitarismo consistiu em refletir sobre a inadequação das categorias tradicionais para tratar sobre os regimes nazista e stalinista.

De forma semelhante ao procedimento realizado em "Compreensão e política", o primeiro movimento no livro Sobre a Revolução foi confrontar os conceitos tradicionais. A autora parte da compreensão preliminar que associava revolução a categorias tradicionais para formular sua definição de revolução. Na medida em que Arendt investiga a inadequação das categorias antigas para caracterizar os levantes revolucionários e se vale das informações históricas sobre eles, ela descobre a especificidade do conceito de revolução e sua relação com outros conceitos.

De acordo com Arendt, os eventos revolucionários frequentemente foram classificados como uma espécie de guerra, ou uma mudança de governo (mutatio rerum), ou como golpe de Estado, rebelião ou revolta. Todos estes conceitos são anteriores ao século XVIII. Se as revoluções fossem meras guerras, mutato rerum, golpe de Estado ou rebelião, não teriam feito surgir nada de inédito no mundo. Nesse sentido, estes conceitos tradicionais não conseguem explicar a especificidade e a novidade que os eventos revolucionários representam.

Conforme foi tratado acima, uma revolução não pode ser definida pela concepção de guerra e de violência, ela antes está ligada com poder e resistência. Da mesma forma, as noções de rebelião e revolta também não a definem adequadamente. Rebelião e revolta são termos conhecidos desde a teoria medieval, designam a derrubada de um governante ilegítimo ou de um tirano que abusou de seu poder. A revolta e a rebelião visam à troca de governante: substituir um usurpador por um governante legítimo. Esta troca não envolve o questionamento da forma constitucional, da autoridade e das leis vigentes. ${ }^{27}$ Para dizer de forma resumida, uma revolução envolve a fundação de um novo corpo político, engendra a ação do povo para criar uma nova constituição.

Para Arendt, rebelião e revolta estão relacionadas a um sentido de libertação, a saber, que o governante não pode abusar de seu poder e interferir arbitrariamente na vida privada de seus súditos, ou seja, o que está em posse do poder não pode governar sem respeitar certos direitos e deveres. Já na revolução, o sentido de libertação é ampliado e

\footnotetext{
${ }^{27}$ Ver em Sobre a Revolução, p. 70.
} 
significa, além de estar livre da arbitrariedade e do abuso do poder, ter acesso ao espaço público, abolir a divisão entre governantes e governados:

"Pois a libertação no sentido revolucionário veio a significar que todos aqueles, não só no presente, mas ao longo da história, não só enquanto indivíduos, mas como integrantes da imensa maioria da humanidade, os humildes e os pobres, que sempre tinham vivido na obscuridade e na sujeição ao poder vigente, iriam se levantar e se tornar os soberanos supremos da terra" (Arendt, Sobre a Revolução, p. 69).

Nesse sentido, a revolução, diferentemente da revolta, envolve a criação de novos direitos, uma nova autoridade e um novo corpo político. Não consiste somente numa troca de governante, nem mesmo em uma mudança de governo caracterizada por um movimento natural e cíclico em que uma forma de governo se corrompe e é substituída por outra forma reta. $^{28}$

$\mathrm{Na}$ perspectiva arendtiana, ao se tentar aplicar as categorias cunhadas na Antiguidade e na Idade Média aos eventos revolucionários, fica evidente que elas não abarcam a especificidade e a novidade que as revoluções trouxeram. No entanto, a constatação da insuficiência dos conceitos antigos em definir o evento revolucionário contribui para avançar na compreensão deste evento. Dito de outro modo, este procedimento de confrontar as categorias tradicionais auxilia a identificar a relação de revolução com conceitos e elementos políticos chave. Ao tratar de guerra e revolução, Arendt, em primeiro lugar, entende que a revolução está intimamente ligada à ideia de liberdade e poder. E que, embora os eventos revolucionários frequentemente envolvam guerra e violência, a revolução não pode ser definida por nenhum destes conceitos. Ainda, aponta que a violência é um instrumento marginal cuja finalidade consiste na libertação da opressão. No momento em que Arendt indaga se a revolução guarda íntima conexão com as noções de rebelião e revolta, ela observa que os levantes revolucionários questionam a antiga ordem, desestabilizam a autoridade e as leis pré-estabelecidas. Além disso, ela constata um novo sentido de libertação, que consiste na retirada de restrições e impedimentos de acesso à esfera pública. Em outras palavras, a libertação revolucionária visa à liberdade política, a ampliação do espaço público para que todos participem do governo.

\footnotetext{
${ }^{28}$ Conferir em Sobre a Revolução, p. 47.
} 
Por fim, quando a autora examina se a concepção de mudança de governo pode ser aplicada para explicar o fenômeno da revolução, mais um passo é dado em direção à compreensão daquele conceito: descobre-se que ele carrega consigo o pathos de novidade. Fica claro que o evento revolucionário não consiste apenas na derrubada de um governo, mas principalmente na fundação de um novo corpo político duradouro.

Além deste procedimento de questionar as categorias tradicionais, depois da ruptura com a tradição, Arendt também precisa encontrar um novo modo de tratar o passado. Nesse contexto, a autora retoma algumas experiências políticas por meio da busca da origem das palavras e sua historicidade.

De acordo com a autora, procurar os usos históricos das palavras que denominam eventos políticos não é, de forma alguma, um exercício antiquarista e fútil, mas consiste em refletir sobre a essência destes eventos. Para Arendt,

"Uma maneira de datar o nascimento efetivo dos fenômenos históricos gerais como as revoluções - ou, a propósito, os Estados nacionais, o imperialismo, o regime totalitário e outros - é, naturalmente, descobrir a primeira vez em que aparece a palavra que, a partir daí, passa a se vincular ao fenômeno. É óbvio que todo novo aparecimento entre os homens requer uma nova palavra, quer se cunhe um novo termo para designar a nova experiência, quer se utilize um termo antigo com significado totalmente novo. Isso se aplica duplamente à esfera política, na qual a fala reina" (Sobre Revolução, p.64)

Uma vez que os homens nomeiam os fenômenos do mundo, as palavras guardam sempre uma ligação com os eventos políticos e com o passado, conservam o significado dos fenômenos que as fizeram surgir pela primeira vez. A autora trata novamente da relação entre termos, história e política em Homens em Tempos Sombrios na parte na qual afirma que, no fenômeno da linguagem, "o passado está contido de modo ineliminável, frustrando todas as tentativas de se libertar dele de uma vez por todas. A polis grega continuará a existir na base de nossa experiência política [...] enquanto usarmos a palavra "política"” (Arendt, Homens em Tempos Sombrios, p. 174). Nesse sentido, a história dos termos nos remete para a história política: o nascimento de um termo aponta para o aparecimento de algo novo no mundo, as alterações de seu uso é indício de que algo na vida política foi mudado. 


\subsection{A história do conceito de revolução}

Por meio da investigação histórica e da análise da polissemia de uma palavra, isto é, dos diversos significados que ela carrega, é possível avaliar as continuidades e rupturas nos assuntos políticos. Isto ocorreu com o termo revolução, que originalmente designava o movimento dos astros, depois passou a indicar as mudanças nas formas de governo e, por fim, a fundação de um novo corpo político.

Para definir o significado da palavra revolução, Arendt busca a genealogia deste termo, ou seja, investiga o seu uso político original para, em seguida avaliar as modificações de sentido que ocorreram no decorrer da Modernidade. De acordo com ela, revolução originalmente era um termo astronômico, que designava o movimento circular das estrelas e planetas. Tal movimento é natural e necessário, não tem nenhuma relação com as atividades humanas, como a política, o debate público, a violência, a fabricação, o trabalho etc.

Com Políbio, pela primeira vez, um termo astronômico foi usado no campo político como metáfora para ilustrar uma das características dos assuntos humanos. A anaciclose se referia ao ciclo que as formas de governo conhecidas descreviam. Ao olhar para a história, Políbio entendia que as formas de governo se repetiam em um ciclo de recorrência eterna e irresistível, da mesma forma que o movimento cíclico dos astros no firmamento.

Segundo Arendt, Políbio escreve sobre o movimento constante nos assuntos de Roma a partir de um ponto de vista grego sobre a natureza da ação dos homens. Na perspectiva grega, a mudança é explicada pela mortalidade: os homens são seres mortais, nesse sentido, tanto os agentes como os atos perecem. Além disso, os jovens como seres novos assediam constantemente o status quo. Este assédio dos jovens juntamente com a efemeridade dos atos minam a durabilidade e estabilidade na vida política e levam os assuntos humanos, inevitavelmente, a se moverem entre as formas de governo. Para Arendt, este historiador antigo entende que "os assuntos humanos mudavam constantemente, mas nunca criavam nada inteiramente novo; se existia algo de novo sob o sol, eram apenas os próprios homens, pelo fato de virem ao mundo" (Sobre a Revolução, p. 56). 
A autora assevera que esta noção de mudança que fundamenta o conceito de anaciclose continuou a ser usada até o Renascimento. Dito de outra forma, desde Políbio até o século XVI, os pensadores políticos entendiam que as formas de governo se repetiam ciclicamente. Maquiavel, por exemplo, ao tratar da derrubada violenta de um governo e a subsequente substituição deste por outra forma de governo, usa o mutatium rerum de Cícero. $^{29}$

Quando a palavra revolução foi usada em um sentido político no século XVII, na Revolução Gloriosa, ela estava próxima da concepção de anaciclose: revolução indicava naquele momento que o povo inglês reivindicava retornar a uma forma de governo préestabelecida e anterior, isto é, buscava restaurar o poder monárquico limitado pela lei e a glória anteriores. ${ }^{30}$ Este momento indica a gênese de revolução como termo político que denota o movimento de retorno a uma constituição anterior.

As revoluções Americana e Francesa em seu início também visavam à restauração: no caso americano, os colonos reivindicavam os antigos direitos dos ingleses contra os abusos do governo colonial. No caso francês, os revolucionários inicialmente pretendiam restaurar os direitos e a forma de monarquia anterior ao absolutismo.

"Em outras palavras, devemos examinar a Revolução Francesa e a Revolução Americana, e temos de levar em conta que ambas foram empreendidas, em suas fases iniciais, por homens firmemente convencidos de que iriam apenas restaurar uma antiga ordem das coisas que fora perturbada e violada pelo despotismo da monarquia absoluta ou pelos abusos do governo colonial. Alegavam com toda sinceridade que queriam voltar aos velhos tempos, quando as coisas eram como deveriam ser" (Sobre a Revolução, p. 74).

No entanto, não foi possível o retorno aos antigos direitos dos ingleses nem à antiga monarquia francesa: o movimento de restauração na América desembocou na independência e na tarefa de instituir uma nova forma de governo no Novo Mundo; a luta pela restauração na França derrubou o Antigo Regime e os revolucionários se depararam com a tarefa de criar a República francesa.

Nesse contexto, a palavra revolução ganhou outro sentido: não designava mais restauração, o retorno a um regime antigo e conhecido; ao contrário, passou a designar a fundação de um novo corpo político, a criação de uma constituição que nunca tinha

\footnotetext{
${ }^{29}$ Ver em Sobre a Revolução, p. 65.

${ }^{30}$ Conferir em Sobre a Revolução, p. 72-75.
} 
existido antes. O termo revolução ganhou, no século XVIII, mais um significado, deixou de ser usado para indicar somente um fenômeno natural e também passou a nomear eventos estritamente políticos os quais estavam ligados à novidade, isto é, ao surgimento de algo inédito na história. O calendário revolucionário criado em 1793 é a expressão de que os homens tomaram a consciência de que suas ações iniciaram uma nova era, um novo período na história.

"O conceito moderno de revolução, indissociavelmente ligado à ideia de que o curso da história de repente se inicia de novo, de que está para se desenrolar uma história totalmente nova, uma história jamais narrada ou conhecida antes, era desconhecido antes das duas grandes revoluções no final do século XVIII" (Sobre a Revolução, p. 56).

Nesse sentido, a historicidade desta palavra sugere tanto aquilo que foi cristalizado quanto aquilo que sofreu transformação. Com as Revoluções Americana e Francesa, o termo revolução passou a indicar o surgimento de algo inédito na história. Mesmo assim, a palavra ainda guarda um pequeno traço de seu sentido original, uma vez que ela continua a indicar um movimento na vida política, que não é mais entendido como uma trajetória natural e pré-determinada, mas como uma ruptura na história provocada pela ação de homens em conjunto.

No século XIX, o termo revolução sofreu novamente uma mudança em seu uso e é deslocado do campo político para o histórico com as interpretações baseadas na noção de progresso e de tendência histórica. Por um lado, Marx relaciona a revolução com necessidade no registro histórico e biológico: a luta de classes como motor da história conduz à revolução definida como transformação radical que daria luz a uma sociedade igualitária e sem classes. Por outro lado, a noção de história como progresso entende a revolução como momento de ascensão da burguesia e de aceleração do processo de evolução econômica e social. Já no século XX, com a emergência do stalinismo, com os levantes revolucionários em Cuba e na China, o conceito de revolução passa a ser relacionado também com totalitarismo, guerra, golpe de Estado e ditadura.

Com tal polissemia, revolução se torna, para Arendt, um conceito opaco que pouco auxilia na compreensão da contemporaneidade. Levando isso em conta, a autora começa sua análise apontando o equívoco do pensamento político de seu tempo, as indistinções entre poder e violência, revolução, guerra, rebelião e mudança de governo. Em $A$ Condição 
Humana a autora indica que a tarefa de definir um conceito está relacionada com a distinção. Em suas palavras, "não podemos dizer o que uma coisa é sem distingui-la de outra”. (A Condição Humana , p. 220). Em seguida, Arendt procura a origem do conceito que foi mal compreendido e sua mudança ao longo do tempo.

O procedimento de distinção que Arendt realiza para apontar os problemas do pensamento político foi tratado por Duarte e Bernstein. O primeiro comentador enfatiza o caráter relacional das distinções; o segundo, seu caráter exagerado. Duarte examina detidamente a distinção arendtiana entre os conceitos de poder e violência. Como já foi mencionado acima, para a autora, poder surge com a ação em conjunto entre os homens e pressupõe um acordo entre muitos; já a violência é um instrumento que potencializa o vigor físico e seu efeito é a obediência. Segundo este comentador, Arendt mobiliza a distinção conceitual em razão da identificação entre poder e violência realizada pelo pensamento ocidental ${ }^{31}$, que considera a política como uma divisão entre governantes e governados, e as relações de poder como formas de dominação. A violência, nesta perspectiva, gera poder na medida em que consiste em meios de coerção e sustenta a relação de mando e obediência. ${ }^{32}$

Esta indistinção entre poder e violência se fundamenta no fato de que no mundo dificilmente um governo se baseia na violência ou no poder em seu estado puro. De acordo com Duarte, a distinção conceitual de Arendt permite avaliar os governos ao refletir em que medida eles se assentam no poder e em que medida recorrem à violência, isto é, como se dá a combinação entre poder e violência. Em suas palavras: “[...] a relação de proporcionalidade entre poder e violência revela seu caráter heurístico na caracterização e avaliação das diferentes formas de governo [...]" ("Poder e Violência no Pensamento de Hannah Arendt: uma reconsideração", p. 157). Na perspectiva do autor, a distinção de Arendt, além de estabelecer uma fronteira entre poder e violência, também constitui uma relação entre os conceitos. Dito de outra forma, este procedimento parte de uma descrição analítica que separa e também conecta os conceitos. Duarte ressalta que a distinção

\footnotetext{
${ }^{31}$ Weber, Platão e Aristóteles são citados como exemplos. Conferir em Duarte, "Poder e violência no Pensamento de Hannah Arendt: uma reconsideração".

${ }^{32}$ Ver em "Poder e violência no Pensamento de Hannah Arendt: uma reconsideração", p. 137.
} 
conceitual não foi mobilizada somente para tratar de poder e violência e que este procedimento é central em toda obra de Arendt.

Bernstein, ao discutir sobre a violência, trata das distinções realizadas por Arendt. Segundo este comentador, a autora busca a essência dos conceitos e as apresenta de forma exagerada, isto é, enfatiza a oposição entre eles. Ele cita um trecho de uma carta destinada a Jaspers, em que a própria autora esclarece seu procedimento de exposição das definições de conceitos:

“'exagero', claro. 'As relações entre ideias', como você diz, dificilmente podem ser apresentadas de outro modo [...] é da natureza do pensamento exagerar. Quando Montesquieu diz que o governo republicano é baseado no princípio da virtude, ele está exagerando também." (Violence: thinking without banisters, p. 97). ${ }^{33}$

Quando Arendt apresenta sua distinção entre poder e violência, ela o faz de modo exagerado, enfatiza mais suas diferenças do que suas relações. Para Bernstein, este exagero ou ênfase visa a compreender algo que corre o risco de ser esquecido: a autora tem como objetivo lembrar que poder e violência não são a mesma coisa, ainda, indica que a política e a ação podem ser distorcidas quando estes conceitos são amalgamados. ${ }^{34}$

Podemos notar que este procedimento de distinção é mobilizado em Sobre a Revolução tanto para distinguir revolução de outras categorias, como guerra, mudança de governo, rebelião, como para indicar o papel do poder e da violência nas revoluções. Nesse sentido, o caráter exagerado da distinção é usado para opor revolução a outras categorias e lembrar que este fenômeno tem uma essência própria. Já o caráter relacional da distinção indica que a violência deve ser empregada numa revolução somente para derrubar o regime precedente e o poder é o único capaz de fundar um novo corpo político.

Outro procedimento mobilizado em Sobre a Revolução consiste na busca da origem do conceito. Os comentadores Correia e Young-Bruehl indicam que esta forma de análise está relacionada com a formação intelectual de Arendt marcada pelo estudo da fenomenologia:

Para Young-Bruehl, Arendt faz uma

\footnotetext{
${ }^{33}$ No original: “'Exaggeration' - of course. 'Relationships between ideas', as you say, can hardly be presented any other way [...] It's the nature of thought to exaggerate. When Montesquieu says that republican government is based on the principle of virtue, he is 'exaggerating' too."

${ }^{34}$ Conferir em Violence: thinking without banisters, p. 98.
} 
“'análise conceitual'; sua tarefa era descobrir de onde vêm os conceitos. Com a ajuda da filologia ou da análise linguística, retraçava o caminho dos conceitos políticos até as experiências históricas concretas e geralmente políticas que davam origem a tais conceitos. Era então capaz de avaliar a que ponto o conceito afastara-se de suas origens e mapear a miscelânia de conceitos através do tempo, marcando pontos de confusão linguística e conceitual. Ou, dizendo de outra maneira: ela praticava uma espécie de fenomenologia." (Por Amor ao Mundo, p. 286).

De acordo com a comentadora, este procedimento foi elaborado em $A$ Condição Humana e visava a encontrar a origem e significado de um termo no passado e, em seguida, comparar com o significado no presente. Isto permitia identificar os problemas do pensamento político em seu tempo - a miscelênia dos conceitos - e quanto os conceitos se afastaram de seu sentido original.

Segundo Correia, este regresso ao passado consiste no traço fenomenológico do pensamento de Arendt e se destina a identificar o significado original dos termos e também a apontar para a configuração dos modos de vida em diferentes momentos históricos. Ele afirma, entretanto, que a forma arendtiana de tratar o passado não tem como referência apenas o pensamento de Jaspers e Heidegger, mas também se apoia em Benjamin e Nietzsche. ${ }^{35} \mathrm{O}$ comentador ressalta que Nietzsche, antes dos demais autores, já havia formulado uma análise genealógica em que as palavras eram consideradas portadoras de um significado e desveladoras de um contexto histórico.

Nesse sentido, Young-Bruehl e Correia esclarecem que a análise linguística e a genealogia consistem em formas adequadas de recuperar o passado no momento em que a tradição foi rompida, e que este procedimento é resultado do referencial teórico de Arendt, não de uma nostalgia saudosista da Antiguidade.

O procedimento de retomar o passado por meio das palavras e sua ligação com a crise da tradição é discutido pela própria Arendt especificamente em Homens em Tempos Sombrios a propósito do texto sobre Walter Benjamin. De acordo com a autora, Benjamin sabia que a ruptura com a tradição era irreparável e que era preciso encontrar novas formas de tratar o passado: "Nisso tornou-se mestre ao descobrir que a transmissibilidade do passado fora substituída pela sua citabilidade [...]" (Homens em Tempos Sombrios, p. 166).

\footnotetext{
${ }^{35}$ Conferir em Hannah Arendt e a Modernidade, p. XXII e XXIII.
} 
O passado, a partir do século $\mathrm{XX}$, deve ser entendido como um estoque de experiências e ideias que podem ser citadas. A citação consiste em selecionar um pedaço de um todo, isto é, selecionar algo ao separá-lo de seu contexto. Assim, citar significa dissolver uma imagem fixa e completa do passado. Nas palavras de Arendt, o olhar para o pretérito deve construir uma reflexão sobre os fragmentos que sobraram dos eventos históricos:

“[...] esse pensar sonda as profundezas do passado - mas não para ressuscitá-lo tal como era e contribuir para a renovação de eras extintas. $O$ que guia esse pensar é a convicção de que, embora o vivo esteja sujeito à ruína do tempo, o processo de decadência é ao mesmo tempo um processo de cristalização, que nas profundezas do mar, onde afunda e se dissolve aquilo que outrora era vivo, algumas coisas sofrem uma 'transformação marinha' e sobrevivem em novas formas e contornos cristalizados que se mantêm imunes aos elementos, como se apenas esperassem o pescador de pérolas que um dia descerá até elas e as trará ao mundo dos vivos - como 'fragmentos de pensamentos', como algo 'rico e estranho' [...]" (Arendt, Homens em Tempos Sombrios, p. 176).

Em outras palavras, estas pérolas e corais não revelam o passado enquanto tal, uma vez que sofreram uma transformação marinha e são apenas vestígios do que foram originalmente. Eles são pescados, retirados de uma peça maciça, isto é, de seu contexto, porque brilham no fundo do mar: têm um significado que diz algo sobre o presente.

De acordo com a autora, Benjamin se volta ao estudo da linguagem, pois ele pode conduzir ao passado no momento em que a tradição não é mais capaz de transmiti-lo.

"Há boas razões para que o interesse filosófico de Benjamin desde o início tenha se concentrado na filosofia da linguagem, e para que finalmente o nomear através de citações tenha se convertido para ele na única forma possível e adequada de tratar o passado sem o auxílio da tradição" (Homens em Tempos Sombrios, p. 174).

É possível afirmar que Arendt se apropria de alguns aspectos deste modo benjaminiano de tratar o passado. A busca pela origem de um termo parece estar baseada na constatação de que a ruptura com a tradição é irreparável, fundamenta-se na concepção de que o passado está contido na linguagem e de que a historia das palavras pode revelar os a momentos históricos que são significativos para o presente.

Em outras palavras, uma vez que os conceitos tradicionais não respondem às questões contemporâneas, encontrar a experiência que fez surgir um termo e seu significado original é o primeiro passo para compreender os deslocamentos e novos 
significados deste termo, um caminho para identificar as rupturas e continuidades entre o passado e o presente e refletir sobre a especificidade do evento que se quer compreender.

Nessa perspectiva, como os conceitos tradicionais não abarcavam a novidade dos eventos revolucionários, Arendt, para cunhar o conceito de revolução, precisava conhecer a origem e a historia do termo.

É possível notar que o surgimento dos regimes totalitários e o grande dilema do século XX levaram Arendt a rever a teoria política, as formas de recuperar o passado e a confrontar as antigas categorias para compreender o presente. Ao mesmo tempo em que estes regimes provocaram um novo olhar para o passado, livre do fio condutor da tradição, eles não permitiram que Arendt compreendesse da mesma forma que antes as revoluções e os conceitos políticos como ação, liberdade, poder, dominação, violência etc.

Vimos acima que a autora procura a genealogia do conceito de revolução e procura identificar sua historicidade na Modernidade em dois registros: factual e conceitual, isto é, por um lado, procura identificar como alguns eventos mudaram o significado do termo revolução, e, por outro, como estes eventos foram interpretados pela teoria política. Dessa forma, ela avalia os novos riscos e potencialidades da ação e também identifica os problemas do referencial teórico contemporâneo para compreender o mundo. Veremos a seguir que a autora faz um procedimento semelhante com o conceito de liberdade: ela procura sua origem e avalia sua historicidade no campo teórico e político.

\subsection{Liberdade e revolução}

Uma vez que a revolução foi entendida como um fenômeno político intimamente ligado à liberdade, para compreendê-lo completamente é importante tratar agora do conceito de liberdade. Nas palavras de Arendt: “Assim o fundamental para qualquer compreensão das revoluções na era moderna é a convergência entre a ideia de liberdade e a experiência de um novo início" (Sobre a Revolução, p. 57).

A definição mais clara e elementar de liberdade, no entanto, é enunciada apenas no último capítulo, quando a autora relaciona ser livre com participação: "Pois a liberdade política, em termos gerais, significa o direito de ser 'participante do governo' - afora isso, 
não é nada" (Sobre a Revolução, p. 278). No início do livro, liberdade é apresentada em distinção às noções de libertação e direitos civis. Segundo Arendt, isso se faz necessário em razão da liberdade ser, por vezes, confundida com libertação e liberdades individuais. Apenas depois de diferenciar tais conceitos, ela examina os aspectos sob os quais a liberdade apareceu pela primeira vez. Aqui não seguiremos o movimento argumentativo do livro, mas expor-se-á primeiro o momento em que a liberdade nasceu enquanto fenômeno político para depois distinguir liberdade de libertação e de direitos civis.

De acordo com Arendt, a liberdade apareceu originalmente na polis grega quando os homens criaram um espaço de convivência onde debatiam e agiam com base na isonomia. A palavra isonomia indica um tipo específico de igualdade, que não está ligada à condições naturais ou econômicas, mas está relacionada a uma convenção, um acordo entre os homens de que, naquele espaço, todas as diferenças naturais e de posses serão desprezadas e que todos têm igual direito de falar, ouvir, ver e ser visto. Os historiadores Heródoto e Tucídides indicam para a autora o sentido de isonomia: o primeiro trata da isonomia como forma de governo em que os cidadãos se recusam a dominar ou serem dominados; já o segundo relaciona a democracia à isonomia. ${ }^{36}$

A autora afirma que, embora todos os cidadãos gregos possuíam condições de vida semelhantes - todos eram proprietários e a grande maioria tinha sua subsistência garantida pelo trabalho escravo -, eles se consideravam desiguais por natureza e só poderiam se tornar pares no espaço político, onde estabeleceram uma igualdade artificial. ${ }^{37}$ Nesse sentido, a liberdade tem limites espaciais: se dá apenas no lugar onde se estabelece a isonomia. Como a isonomia não é um princípio de validade universal, a liberdade também não pode ser universal, não pode existir em todos os espaços. ${ }^{38}$ Ela precisa de um espaço público, um lugar onde as pessoas possam se reunir para debater como pares, trocar opiniões, ver e ouvir outras perspectivas.

A liberdade, por possuir limites espaciais e estar relacionada à isonomia, manifestase particularmente na ação política, ela não se manifesta em todas as atividades realizadas pelos homens. Em A Condição Humana Arendt apresenta as três atividades humanas:

\footnotetext{
${ }^{36}$ Conferir sobre Heródoto e Tucídides nas notas 11 e 12 do primeiro capítulo de Sobre a Revolução.

${ }^{37}$ Conferir em Sobre a Revolução p. 58.

${ }^{38}$ Sobre a limitação espacial da liberdade, ver em Sobre a Revolução p. 344.
} 
trabalho, fabricação e ação. O trabalho consiste na atividade que atende o processo biológico do corpo, está ligado à reprodução da vida, à produção daquilo que o organismo necessita para sobreviver. Nesta perspectiva, o trabalho não se relaciona com a liberdade, mas é pautado pela necessidade.

A fabricação consiste na produção de bens duráveis, tais como ferramentas, obras de arte, artefatos culturais, edifícios etc. Esta atividade é responsável por produzir um mundo propriamente humano, diferente do ambiente natural. A fabricação de um bem durável não é pautada pela necessidade biológica nem pela liberdade, ela é baseada na utilidade e organizada pela categoria de meios e fins: o fabricante define os instrumentos e a forma de fazer o objeto a partir da ideia ou do modelo do que se quer produzir. ${ }^{39}$

Já a ação consiste na atividade política, ela se efetua na relação entre os homens em contraste com o trabalho e a fabricação, que se realizam na relação entre homem e natureza. ${ }^{40}$ A condição e a razão de ser da política está na pluralidade humana, isto é, no fato de que no mundo convivem diversas pessoas, cada uma com sua singularidade distinta. Nesta perspectiva, a pluralidade não consiste nas diferenças naturais entre os indivíduos da mesma espécie, não diz respeito à convivência entre animais que vivem em conjunto por causas biológicas; ela está relacionada ao fato de que os homens são seres singulares, cada qual com sua subjetividade e que podem organizar o mundo e a relação entre si livremente, ou seja, sem serem determinados por leis naturais ou biológicas. ${ }^{41}$

A autora define estas três atividades a partir dos modos de vida que Aristóteles distinguia, a saber, o modo de vida do escravo que é coagido pela necessidade de sobrevivência e pelo mando de seu senhor e está fatalmente fadado à atividade do trabalho; o modo de vida dos artesãos livres e mercadores, que está ligado à fabricação; e o modo de vida do cidadão, o qual é dedicado aos assuntos da polis. ${ }^{42}$ Nesse sentido, a liberdade era experimentada somente por aquele que se dedicava aos assuntos políticos, uma vez que o

\footnotetext{
${ }^{39}$ Os produtos da fabricação estão ligados ao belo e ao útil, mas não à sobrevivência, que se refere ao trabalho.

${ }^{40}$ Segundo Arendt, a vida humana em sentido não biológico se manifesta na fala e na ação. "Com a palavra e o ato nós nos inserimos no mundo humano, e esta inserção é como um segundo nascimento, no qual confirmamos e assumimos o fato bruto de nosso aparecimento físico original" (Arendt, "Trabalho, obra e ação", p. 190). Este segundo nascimento significa para a autora o aparecimento do homem enquanto ser existente no mundo, inter-relacionado com os seus iguais.

${ }^{41}$ Sobre a definição inicial das três atividades humanas, conferir em $A$ Condição Humana p. 8-10.

${ }^{42}$ Conferir em $A$ Condição Humana p. 14 e 15 . Não tratarei aqui da vida contemplativa, modo de vida dos filósofos que se dedicam à investigação e contemplação da verdade e das coisas eternas.
} 
escravo era guiado pela necessidade, e o artesão e mercador, pela utilidade das coisas produzidas.

A ligação entre ação e liberdade também é articulada no ensaio "Que é Liberdade?". ${ }^{43}$ Ser livre, para a autora, significa agir em um espaço publicamente organizado. "Os homens são livres - diferentemente de possuírem o dom de liberdade enquanto agem, nem antes, nem depois; pois ser livre e agir são uma única e mesma coisa" (Arendt, Entre o Passado e o Futuro, p. 199). Para descrever a ação, Arendt recorre à mesma metáfora que os gregos usavam: a comparação da política com as artes de realização, como tocar flauta e dançar. Essas artes são diferentes das artes de fabricação, em que o artista produz a obra no isolamento e somente depois a expõe para o público. Nas artes de realização, o artista executa a obra na presença de um público. O mais importante neste tipo de arte é o virtuosismo apresentado pelo artista, sua excelência no desempenho. Para ilustrar a ação, no artigo “Que é liberdade?", Arendt faz uma analogia com o teatro: o agente, assim como o ator, realiza uma performance diante de um público e busca conquistar a benevolência da audiência por meio do virtuosismo. $\mathrm{O}$ agente deve ser excelente em sua performance para persuadir os demais a apoiarem e sustentarem o ato. ${ }^{44}$ Já em Sobre a Revolução, a autora acrescenta a esta analogia o termo persona. ${ }^{45}$ Persona, originalmente, designava uma máscara usada no teatro romano, ela tinha como função esconder o rosto do ator de maneira que sua voz ressoasse do palco para o público. Mais tarde, o termo passou para a linguagem jurídica e simbolizava as leis e diretos que os cidadãos possuíam. Metaforicamente falando, o termo persona indicava que os cidadãos romanos tinham um papel e uma personalidade públicos diferente de suas tarefas e modo de ser na vida privada. Nesse sentido, para aparecer na esfera política, os homens devem possuir direitos, no mínimo o direito de falar aos seus pares, e expressar suas opiniões, esclarecer os princípios de seus atos.

Por depender do virtuosismo da execução e de uma apresentação pública, a arte de realização pode ser uma boa metáfora para as atividades políticas: "Se entendermos então o político no sentido da polis, sua finalidade, sua raison d'être seria estabelecer e manter

\footnotetext{
${ }^{43}$ A reflexão sobre o conceito de liberdade aqui é fundamentalmente extraída da minha dissertação de mestrado intitulada Liberdade em Hannah Arendt.

${ }^{44}$ Conferir em Entre o Passado e o Futuro, p. 200.

${ }^{45}$ Sobre a Revolução, p. 148.
} 
em existência um espaço em que a liberdade, enquanto virtuosismo, pudesse aparecer" (Arendt, Entre o Passado e o Futuro, p. 201).

É curioso que Arendt retoma a Antiguidade para definir seu conceito de liberdade ao tratar de isonomia, das atividades humanas - a partir das figuras do escravo, artesão e cidadão - presentes no pensamento aristotélico, e ao retomar a metáfora usada pelos gregos para descrever a ação, mas não recorre ao procedimento da origem da palavra liberdade. A autora não fala do surgimento do termo eleutheria ou libertas. ${ }^{46}$ De forma distinta, para definir outros conceitos, como revolução, autoridade, ação e fundação, a autora busca a origem da palavra para iniciar a discussão sobre o significado do termo. Não fica claro em seus escritos o motivo pelo qual os termos eleutheria e libertas não são o ponto de partida para sua reflexão acerca da liberdade.

Para discutir o que é liberdade, Arendt não volta ao passado por meio da busca da origem da palavra; ela cita autores antigos: Aristóteles, para tratar das atividades humanas, e Heródoto e Tucídides para mostrar o significado de isonomia. Tais autores não são lidos como filósofo e historiadores, mas como testemunhas da mentalidade e valores gregos. ${ }^{47}$ Para dizer de forma diferente, estes autores não são retomados por meio da tradição, suas doutrinas e metodologias não são apresentadas, eles são recuperados de modo benjaminiano: deles são recortados "fragmentos de pensamento".

Além dos autores antigos, Arendt também cita Maquiavel. Para a autora, a ação livre é bem explicitada por Maquiavel em seu conceito de virtù: "Talvez a melhor ilustração da liberdade enquanto inerente à ação seja o conceito maquiavélico de virtù, a excelência com que o homem responde às oportunidades que o mundo abre ante ele à guisa da fortuna" (Arendt, Entre o Passado e o Futuro, p. 199).

\footnotetext{
${ }^{46}$ De acordo com alguns historiadores, a palavra eleutheria significava 'não escravo' e a partir da experiência das Guerras Persas, também se referia à liberdade da cidade, isto é, sua independência e autonomia para resolver seus próprios assuntos. Mais tarde, em Atenas, surgiu a ideia de liberdade relacionada aos cidadãos quando a tirania passou a ser vista como a principal inimiga da cidade. Já a palavra libertas, segundo alguns historiadores, estava ligada à fundação de Roma. Significava, de um lado, a proteção da autoridade do Senado contra os interesses privados de líderes populares; e, de outro lado, a proteção do povo contra abusos do poder. Nesse sentido, liberdade na Roma Antiga estava relacionada ao direito: a lei tanto protegia a vida privada do poder como protegia a autoridade pública dos interesses privados. Sobre o conceito de libertas, conferir Romilly, Les usages de la liberté.

${ }^{47}$ Arendt afirma que Aristóteles por vezes apenas articula a opinião pública grega sobre a vida política. Ver em Entre o Passado e o Futuro, p. 158.
} 
$\mathrm{Na}$ interpretação de Arendt, a fortuna pode dar a oportunidade ao agente, mas este tem o poder de moldar o mundo somente se sua performance for excelente para persuadir o público a se juntar à ação.

Diferentemente dos autores antigos, Maquiavel neste trecho não é interpretado como um testemunho de uma mentalidade ou de algum valor. Contudo, também não é lido do ponto de vista da história da filosofia. A autora não retoma todo o pensamento do autor renascentista, mas retira apenas uma parte do todo: ela relaciona seu próprio conceito de liberdade e de ação com virtù, mas não trata de todas as facetas do conceito cunhado por Maquiavel. Por exemplo, ela nada diz sobre a virtù militar, ponto em que os autores entrariam em debate uma vez que, para Arendt, a ação não está relacionada com o uso da violência e da força. Além disso, não sabemos por que ela mobiliza mais a relação entre virtù e fortuna, que se refere à atuação do príncipe, do que a relação entre tempos e modo de proceder que está ligada à ação dos cidadãos na república. Dito de outra forma, uma vez que a autora entende que a ação envolve uma pluralidade de agentes, é surpreendente que ela retome mais a obra Príncipe do que os Discursos.

Arendt, nesta leitura do pensamento maquiaveliano, parece se apropriar do procedimento benjaminiano de citação. Como mencionado acima, Benjamin seleciona do passado pérolas e corais que dizem algo sobre o presente, destaca-os do todo, retira-os de seu contexto. Arendt faz o mesmo com o pensamento de Maquiavel. Não retoma toda sua obra, nem mesmo a totalidade do conceito de virtù, mas apenas retira a parte que ela julga iluminar a ação: a dimensão do virtuosismo com que o agente interfere nos rumos do mundo.

Para ela, virtù é a resposta que o homem dá ao mundo diante da fortuna. ${ }^{48}$ Aqui o conceito maquiaveliano parece ser entendido pela autora como uma intervenção na fortuna.

\footnotetext{
48 Apesar da apropriação do conceito maquiaveliano de virtù por Arendt, a liberdade arendtiana não é entendida nos mesmos termos de Maquiavel. Para ele, a liberdade diz respeito à independência de um governo frente aos governos estrangeiros, no que se refere aos assuntos externos; e nos assuntos internos, a liberdade corresponde à forma republicana de governo. Nesse sentido, para Maquiavel, a liberdade republicana se caracteriza pela ação de diversos atores, está ligada ao conflito entre povo e grandes. Ver em Maquiavel, Discursos sobre a primeira década de Tito Lívio, p. 23 e 465. Aqui pode parecer que Arendt está próxima do pensador florentino, já que, para a autora, ação requer o engajamento de diversos agentes. Entretanto, a pensadora alemã não entende que a comunidade está dividida conforme dois humores. Além disso, embora os dois autores relacionem liberdade e potência, o sentido desta palavra é diferente em cada um: enquanto, para Arendt, potência significa decidir sobre os rumos do mundo, participar dos assuntos
} 
Nesse sentido, Arendt estreita a relação entre virtù e prudência, que significa sabedoria prática: saber julgar e deliberar de acordo com a contingência. A contingência pertenceria ao mundo humano, que, em contraste com o mundo natural, não seria determinado ou condicionado de forma absoluta. ${ }^{49}$

Segundo Arendt, esta indeterminação nos assuntos humanos se deve ao fato de que a política diz respeito a muitos. A ação sempre envolve um iniciador e um público, e, por envolver tal pluralidade de agentes, não pode ser previsível ou condicionada.

A autora parte dos verbos que designavam a ação nas línguas grega e latina para tratar do início e da continuação da ação:

“[...] ambas as línguas possuíam dois verbos para designar aquilo que chamamos uniformemente de agir. As duas palavras gregas são árkhein: começar, conduzir e, por último, governar; e práttein: levar a cabo alguma coisa. Os verbos latinos correspondentes são agere: pôr alguma coisa em movimento; e gerere, que é de árdua tradução e que de certo modo exprime a continuação permanente e sustentadora de atos passados cujos resultados são as res gestae, os atos e eventos que chamamos de históricos" (Arendt, Entre o Passado e o Futuro, p. 214).

Cabe notar aqui que Arendt lança mão do procedimento de análise linguístico ao retomar o significado original de ação na Grécia Antiga e em Roma. Entretanto, a autora não traça a historicidade do termo "ação" até os tempos modernos. ${ }^{50}$ Mesmo em $A$ Condição Humana, quando a mudança na hierarquia das atividades humanas é tratada e são indicados os eventos que alçaram primeiro a fabricação e depois o trabalho como principais atividades na Modernidade e desvalorizaram a ação, a autora menciona apenas uma mudança no significado dos verbos agir nas línguas grega e latina. ${ }^{51}$ Segundo ela, archein e gerere deixaram de significar o ato de iniciar algo, para designar a função de governar e liderar. Com esta mudança, iniciar passou a ser prerrogativa do governante. A

comuns, para Maquiavel, potência diz respeito à força da república. Sobre liberdade e potência em Maquiavel, conferir Bignotto, Maquiavel republicano, p. 92.

${ }^{49}$ É importante afirmar que as circunstâncias determinam mais as ações para Maquiavel do que para Arendt. Para o autor a ação deve estar de acordo com a natureza dos tempos, no pensamento da autora, de forma distinta, a ação tem maior capacidade de mudar as coisas no mundo. Sobre a relação entre natureza dos tempos e modo de proceder em Maquiavel, conferir em Aranovich, "O Riscontro: considerações sobre a política e a história em Maquiavel", p. 80.

${ }_{50}$ Arendt não faz aqui a historicidade da palavra, mas vermos adiante que a autora aponta para uma história do conceito de liberdade.

${ }^{51}$ Sobre os eventos que impactaram a hierarquia das atividades humanas, a saber, a Reforma, a exploração de toda Terra e a invenção do telescópio, conferir em A Condição Humana, p. 309-320. Sobre a desvalorização da ação e sua substituição pelo fazer conferir em A Condição Humana, p. 274-286. 
interdependência original entre aquele que inicia e o público que leva adiante a ação foi diluída de forma que as duas partes da ação foram apartadas: o iniciador passou a ser o governante que dá ordens e o público que levava a cabo o ato, tornou-se o conjunto de súditos que deve obedecer e executar ordens. ${ }^{52}$

Dessa forma, Arendt indica, ao retomar o termo "ação" em grego e latim, que de alguma maneira este termo não é mais entendido no sentido antigo. A autora não aprofunda esta questão e não trata do significado moderno do termo. Isto pode estar relacionado ao fato de que, para ela, a partir da Antiguidade tardia, o espaço público e a atividade política foram reduzidos, de modo que aquele sentido de ação foi em boa parte perdido. A autora restringe então sua análise ao sentido grego e latino de "ação".

A partir desta análise linguística foi possível a Arendt mostrar que tanto gregos como romanos entendiam que a ação era iniciada por um, mas só poderia ser sustentada ou levada a cabo se outros homens se juntassem ao iniciador e se engajassem nela. Esta característica do agir esclarece como os homens podem escolher manter ou mudar o mundo e a forma de convivência entre eles: ao se agir em conjunto, pode-se tanto começar ou fundar algo novo, como se podem manter os atos passados, continuar um estado de coisas. Isto explicita como a história política é composta tanto de continuidades quanto de mudanças.

Levando em conta a experiência, a mentalidade e a linguagem antigas, Arendt estabelece a relação entre liberdade e isonomia, e delimita o lugar e a atividade em que a liberdade se manifesta. A partir dos antigos é possível entender a liberdade como participação nos assuntos públicos. De acordo com a autora, os homens das revoluções setecentistas também buscaram elementos na Antiguidade para entender a atividade política. Foi o interesse pela liberdade política que os levou a ler sobre a polis grega e a República romana. Enquanto a tradição filosófica e cristã só poderiam instruir sobre a liberdade de pensamento e acerca do livre arbítrio, a experiência antiga podia apontar para a liberdade entre os homens:

"A liberdade para eles [homens das revoluções] só podia existir em público; era uma realidade concreta, terrena, algo criado pelos homens para ser usufruído pelos homens, e não um dom ou uma capacidade. Era a praça ou espaço público

\footnotetext{
${ }^{52}$ Conferir em A Condição Humana , p. 236 e 237.
} 
feito pelos homens que a Antiguidade conhecia como a área onde a liberdade aparece e se faz visível a todos" (Sobre a Revolução, p. 169).

Por inspirarem-se no exemplo dos antigos, os homens das revoluções sabiam que, para experimentar a liberdade, era preciso haver um espaço público que permitisse aos cidadãos falar e agir entre iguais. Este lugar de isonomia surgiu na América do Norte nos debates das assembleias municipais e distritos, já na França foram as comunas e assembleias primárias que abrigaram a isonomia. ${ }^{53}$

Para Arendt, assim como os gregos e romanos antigos, os colonos na América do Norte e os franceses que estavam engajados na revolução experimentaram a liberdade enquanto realidade concreta. Contudo, os homens do século XVIII não tinham clareza quanto à diferença entre liberdade e libertação:

"Pois foram suas ações e realizações, exigidas pela libertação, que os lançaram aos assuntos públicos, onde começaram a construir de maneira deliberada ou, na maioria das vezes, inesperada aquele espaço de aparecimentos onde a liberdade pode exibir seus encantos e se converter numa realidade visível e tangível" (Sobre a Revolução, p. 62).

Nesse contexto em que os homens da revolução buscavam libertar-se da opressão e, ao mesmo tempo, acabaram por estabelecer a liberdade, as noções de liberdade e libertação foram amalgamadas.

Arendt, ao perceber que nas revoluções a luta de libertação foi coeva com o estabelecimento da liberdade, viu a importância de diferenciar o significado de liberdade [freedom] e o de libertação [liberation]. De acordo com ela, a distinção entre estes dois conceitos é frequentemente esquecida também em razão da relação entre eles. A libertação é condição para liberdade, mas a conquista da libertação não garante nem conduz necessariamente à liberdade. Em outras palavras, é possível estar liberto da opressão de outrem e, ao mesmo tempo, não ser livre, isto é, não participar do debate e da ação em uma arena política. ${ }^{54}$ Assim, a libertação tem sentido negativo, significa não ser oprimido pela necessidade e não ser dominado por alguém, enquanto que liberdade significa mover-se entre pares para agir.

De modo semelhante, liberdade foi confundida com direitos civis em razão dos homens da revolução nos dois lados do Atlântico terem redigido declarações de direitos

\footnotetext{
${ }_{54}^{53}$ Conferir em Sobre a Revolução, p. 337.

${ }^{54}$ Um governo limitado pode garantir direitos individuais, mas restringir ao máximo a participação política. Ver em Sobre a Revolução, p. 57.
} 
para garantir as liberdades individuais [liberties] ao mesmo tempo em que debatiam e agiam com base na isonomia. No entanto, segundo Arendt, enquanto a liberdade se relaciona positivamente com o poder, os direitos civis se relacionam negativamente: a liberdade é experimentada no debate e na ação entre pares, isto é, na participação no poder político, já as liberdades individuais consistem numa salvaguarda contra o abuso do poder. 55

Assim como a libertação, os direitos estabelecidos na Bill of Rights e na Declaração Universal dos Direitos do Homem e do Cidadão eram condições para a liberdade: garantiam que os indivíduos não estariam à mercê do arbítrio de outrem, isto é, estabeleciam que os homens não deveriam sofrer restrições injustificadas. Conforme Arendt, estas declarações diziam respeito basicamente ao direito à propriedade, à vida e de movimento. Tais garantias são importantes para que seja possível agir e debater entre iguais, mas de maneira alguma elas levam automaticamente à liberdade.

Arendt mobiliza, em Sobre a Revolução, o procedimento de distinção para relacionar e separar liberdade, libertação e direitos civis. Como mencionamos acima, este procedimento foi analisado por Duarte a propósito de discutir a distinção entre poder e violência. ${ }^{56}$ De acordo com este comentador, "aquilo que se distingue mantém uma relação intrínseca com aquilo de que se distingue" ("Poder e violência no Pensamento de Hannah Arendt: uma reconsideração", p. 134). Nesse sentido, o modo de distinção arendtiano não estabelece dicotomias e limites estanques, uma vez que a fronteira que separa os conceitos também estabelece uma conexão entre eles. A distinção que na enunciação do conceito aparece de maneira geral, pode sofrer deslocamento em um evento particular. Por isso, Duarte mostra que em cada forma de governo existe uma proporção diferente entre poder e violência, mas de uma maneira geral existe sempre uma proporcionalidade: quanto mais poder, menos violência, e quanto menos poder, mais violência. No caso que discutimos aqui, não há uma proporcionalidade entre liberdade, libertação e direitos civis, mas há uma distinção e uma relação entre estes conceitos.

Esta relação está no fato de que libertação e direitos civis são condições para instituir a liberdade. Entretanto, essa relação geral aparece de forma diferente na polis

\footnotetext{
${ }^{55}$ Conferir em Sobre a Revolução, p. 60.

${ }^{56}$ Conferir em Sobre a Violência, p. 131-167.
} 
grega, em Roma e nas revoluções. Na Antiguidade, a libertação consistia em estar livre da atividade que garante a subsistência e isso se dava principalmente por meio da imposição do trabalho aos escravos. O direito e a lei com a reforma realizada por Sólon, a qual extinguiu a escravidão por dívidas, garantiram na polis que nenhum ateniense ficaria sob o jugo de outrem. Já em Roma, a lei e o direito garantiam que o poder público não interferiria na vida privada. Em ambas as cidades antigas, a libertação e os direitos eram permanentes, estavam bem estabelecidos e precederam temporalmente a liberdade. De maneira diferente, os homens das revoluções não estavam completamente livres do domínio de outrem no início dos eventos revolucionários. Apenas em alguns momentos, que eram intermitentes, eles conseguiam escapar do domínio colonial e absolutista, ou seja, deixar a luta contra a dominação e opressão para debaterem e agirem livremente. Além disso, como muitos que participaram das revoluções não possuíam escravos, eles dividiam seu tempo entre os afazeres que garantem a subsistência e os assuntos públicos. No contexto revolucionário, os direitos civis nem sempre precederam a liberdade e a luta pela libertação se deu ao mesmo tempo, mas não no mesmo espaço, que o florescimento da liberdade.

Aqui é possível notar uma diferença entre a liberdade que estava abrigada dentro de um corpo político bem estabelecido - na polis grega e na República romana a liberdade fora institucionalizada - e a liberdade que abre um espaço público num contexto de dominação.

Conforme Arendt, a dificuldade de compreender a liberdade vem, por um lado, do fato de que libertação e direitos civis são condições para a liberdade regular e institucionalizada e de que a luta por direitos civis, o combate à opressão e a ação podem ocorrer no mesmo período de tempo. Por outro lado, a dificuldade de compreender a liberdade vem da tradição filosófica que, desde seu início, não tratou de uma liberdade no mundo, de forma diversa, tratou da liberdade como um atributo encontrado no interior do sujeito. Em suas palavras:

“[...] a liberdade desempenhou um papel importante e bastante controvertido na história do pensamento filosófico e também do pensamento religioso, e isso ao longo daqueles séculos - entre o declínio da era antiga e o nascimento do mundo moderno - em que não existia liberdade política [...]" (Sobre a Revolução, p. 57). 
Neste sentido, a autora faz uma ligação entre o desenrolar da história e o próprio conceito filosófico de liberdade: para ela, a liberdade passou a ser tratada como pertencente ao domínio interno quando deixou de ser experimentada publicamente no final do Império Romano. No artigo “Que é liberdade?”, Arendt aponta com mais clareza os problemas que a filosofia fez surgir para pensar a liberdade em sentido público.

\subsection{Liberdade na tradição filosófica}

Segundo a autora, a liberdade foi a última das grandes questões metafísicas a se tornar tema de interesse para a filosofia. Ela se transformou em um problema filosófico primeiramente com Epiteto, ${ }^{57}$ e com a tradição cristã este conceito foi consolidado: no pensamento de Agostinho, a liberdade se tornou livre arbítrio. De acordo com a autora, a vontade foi inserida como o árbitro da dicotomia entre razão e paixões, dicotomia que havia sido problematizada desde os gregos. No pensamento cristão, a vontade escolhe as coisas livremente uma vez que não é compelida pela verdade ou determinada pelo desejo. ${ }^{58}$ Para Arendt, a liberdade foi entendida como algo interior, ligada à vontade, quando o regime político Romano não permitiu mais que se experimentasse a liberdade no espaço público. Quando o mundo público se tornou hostil, os homens se voltaram para as atividades do espírito, ou seja, a coerção externa fez com que se buscasse a liberdade na interioridade. $^{59}$

“[...] a interioridade, como região de absoluta liberdade dentro do próprio eu, foi descoberta na Antiguidade tardia por aqueles que não possuíam um lugar próprio no mundo e que careciam portanto de uma condição mundana [...]" (Arendt, Entre o Passado e o Futuro, p. 192).

Arendt em $A$ vida do Espírito apresenta uma outra forma de liberdade interior: o pensamento livre. Ela distingue a noção de liberdade filosófica da de liberdade política: a

\footnotetext{
${ }^{57}$ Arendt, ao tratar do estoicismo somente por meio do pensamento de Epiteto, reduz esta doutrina filosófica. Panécio e Cícero, por exemplo, desenvolvem o estoicismo de forma extremamente preocupada com a ação e a com a vitalidade da República.

${ }^{58}$ Conferir em Responsabilidade e Julgamento, p. 179 e 185.

${ }^{59}$ Nas palavras de Duarte (O Pensamento a Sombra da Ruptura, p. 205), para Arendt, "as experiências de uma liberdade estritamente interna são derivativas e marcam o início de um distanciamento em relação ao mundo, refletindo a própria impossibilidade de a liberdade aparecer e ser experimentada publicamente".
} 
primeira está ligada ao conhecimento e interpretação do mundo, enquanto que a segunda está relacionada à mudança do mundo.

A liberdade filosófica, a liberdade da vontade, é relevante somente para as pessoas que vivem fora das comunidades políticas, como indivíduos solitários. As comunidades políticas, nas quais os homens se tornam cidadãos, são produzidas e preservadas por leis; e tais leis, feitas pelos homens, podem variar muito e podem dar forma a inúmeros tipos de governo, todos eles, de uma maneira ou de outra, tolhendo a vontade livre de seus cidadãos (Arendt, $A$ Vida do Espirito, p. 335).

A liberdade filosófica se diferencia da liberdade política porque está ligada à interioridade, à cisão entre querer e não querer e é independente das condições externas, enquanto que ser livre politicamente significa potência: agir para mudar algo no mundo. Este poder surge somente na esfera pública, quando os homens se unem para agir de comum acordo. Tal união se baseia num assentimento, que para a autora implica um reconhecimento de que nenhum homem pode agir sozinho para realizar algo no mundo: "A ação, em que um nós está sempre engajado em mudar nosso mundo, mantém a oposição mais aguda possível com a atividade solitária do pensamento, que funciona no diálogo de mim comigo mesmo" (Arendt, $A$ vida do Espírito, p. 336). ${ }^{60}$

No ensaio “Que é liberdade?”, Arendt defende que só é possível tomar consciência da liberdade ou da sua falta no relacionamento com os outros, na esfera da experiência, não no pensamento ou no diálogo do sujeito consigo mesmo. A liberdade ou a dominação apenas possui realidade concreta no inter-relacionamento humano, apenas pode ser um fato demonstrável na esfera política, não na mente ou no coração dos homens.

A consequência dessa ideia de liberdade ligada à vontade é o distanciamento dos assuntos comuns e a valorização do isolamento necessário para se travar o diálogo interior. ${ }^{61}$ Arendt mostra que o tema da liberdade na tradição cristã surgiu com a destruição

\footnotetext{
${ }^{60}$ Para Arendt, enquanto a noção de liberdade filosófica trata do Homem, a de liberdade política se ocupa da associação entre os homens. Ver em Arendt, A promessa da política, p. 144-146.

${ }^{61}$ De acordo com Kalyvas, no artigo "From the act to decision: Hannah Arendt and the Question of Decisionism", embora Arendt afaste a faculdade da vontade da política em Entre o Passado e o Futuro, em seu último livro, $A$ vida do espírito, ela relaciona vontade com novos inícios. Para o autor, são três as razões desta mudança: primeiro, a autora aponta para uma similaridade entre liberdade política e vontade. Ambas não podem ser explicadas por relações causais, são auto-determinadas, e operam por meio da espontaneidade e, por isso, desestabilizam o curso ordinário da vida. A segunda razão consiste em que a vontade é descrita em $A$ vida do Espirito como a faculdade voltada para o futuro que é capaz de conceber novos projetos. Em terceiro lugar, a vontade é descrita como a faculdade responsável pelo caráter do indivíduo, ela define como o sujeito quer aparecer no mundo e por isso pode ser relacionada com a moral e a responsabilidade do agente. Esta faculdade, portanto, faz com que um homem seja diferente de outro, está de certa maneira ligada à
} 
dos espaços públicos experimentada no fim do Império Romano e que a liberdade como livre arbítrio, longe de problematizar o isolamento dos homens e a redução da vida política, consolida a noção de que a liberdade é vivida na solidão.

Além da tradição cristã, o liberalismo também define a liberdade como algo que não se manifesta no espaço público. Na perspectiva liberal, ser livre consiste na independência individual, na liberdade de escolha com relação às atividades do trabalho e fabricação. Duas condições são necessárias para que seja possível esta liberdade individual: é preciso estar liberado dos assuntos públicos e é preciso haver um governo que não interfira no espaço privado, que garanta a segurança de seus membros.

Apesar de Arendt não indicar com clareza com quais liberais ela dialoga, entendemos que Benjamin Constant condensa esta concepção liberal de liberdade. Nos termos do autor, liberdade para os modernos significa não se submeter senão às leis, ter o direito de ir e vir, de dispor de sua propriedade e de escolher suas crenças, seu trabalho e seus representantes no governo ("Da liberdade dos antigos comparada à dos modernos", p. 10). Segundo o autor, com os progressos da civilização e do comércio, as formas de felicidade particular foram ampliadas, por isso, os indivíduos, na Modernidade, estão mais interessados nos prazeres da vida privada do que na participação na vida pública. Nesse contexto, o sistema representativo seria o mecanismo de governo que mais favoreceria a liberdade moderna, já que preserva o direito de voto e libera a maioria dos indivíduos para as atividades privadas e econômicas. Em suas palavras: "O objetivo dos modernos é a segurança dos privilégios; e eles chamam liberdade as garantias concedidas pelas instituições a esses privilégios” (“Da liberdade dos antigos comparada à dos modernos”, p. $15)$.

Segundo Arendt, os liberais, em certa medida, retomaram Hobbes para relacionar garantia da segurança e governo:

“A segurança continuava sendo o critério decisivo; não a segurança individual contra a 'morte violenta', como em Hobbes (onde a condição de toda liberdade

pluralidade. Nesse sentido, Kalyvas contribui para a compreensão da obra de Arendt ao apontar essa mudança da relação entre vontade e liberdade, na medida em que tal mudança tinha sido negligenciada pelos comentadores. No entanto, essa mudança não pode ser totalmente explicada, uma vez que não sabemos como Arendt iria tratar da faculdade de julgar e qual seria a relação entre juízo e vontade. Dito de outra forma, não sabemos como o querer e o julgar se conectam para formar as escolhas e os projetos dos indivíduos. Dessa forma, ainda fica enigmática a questão de como os projetos novos formados pela vontade no interior do sujeito podem ser apresentados no espaço público. 
é a liberação do medo), mas uma segurança que permitisse um desenvolvimento uniforme do processo vital da sociedade como um todo" (Entre o Passado e o Futuro, p. 196).

O governo, na concepção liberal, torna-se cada vez mais o protetor dos interesses da sociedade e dos indivíduos, o responsável em libertar as pessoas das atividades públicas para se preocuparem com a economia e com a satisfação das necessidades biológicas. E na medida em que o governo tem como principal função a segurança e o processo vital, "a liberdade [para os liberais] não é sequer o desígnio apolítico da política, mas sim um fenômeno marginal, que constitui de certa forma os limites que o governo não deve transpor sob risco de pôr em jogo a própria vida e suas necessidades e interesses imediatos" (Arendt, Entre o Passado e o Futuro, p. 196). Na perspectiva arendtiana, onde quer que o processo vital esteja em jogo, tudo se encontra sob o jugo da necessidade. Para a autora, o liberalismo cria dificuldades para a liberdade nos assuntos públicos na medida em que coloca as funções do governo no registro da necessidade e da segurança: onde elas reinam não há escolha a ser debatida em uma arena pública.

Além da tradição cristã e do liberalismo, Arendt indica que a experiência do século XX também reitera a separação entre política e liberdade. O nazismo e o stalinismo, ao buscarem o domínio total, o controle da vida biológica e social, reforçariam a concepção de que a política é incompatível com a liberdade.

"O ascenso do totalitarismo, sua pretensão de ter subordinado todas as esferas da vida às exigências da política e seu conseqüente descaso pelos direitos civis, entre os quais, acima de tudo, os direitos à intimidade e à isenção política, fazem-nos duvidar não apenas da coincidência da política com a liberdade como de sua própria compatibilidade" (Arendt, Entre o Passado e o Futuro, p. 195).

Arendt, nesse sentido, relaciona as experiências históricas com a mudança no conceito de liberdade: a redução do espaço público na Antiguidade tardia propiciou que a tradição cristã entendesse liberdade como algo que opera no interior do sujeito; a promoção da fabricação e do trabalho na Modernidade levou a liberdade a ser definida como sinônimo de independência individual. Com o surgimento do totalitarismo, por fim, o conceito liberal de liberdade foi promovido.

Uma vez que a tradição cristã, o liberalismo e as experiências totalitárias obliteraram a experiência original de liberdade política, Arendt precisou olhar para os 
momentos em que a ação se tornou a principal atividade, na Antiguidade e nas revoluções, para poder compreender o que é a liberdade no sentido político. Em suas palavras:

"Regressemos pois, mais uma vez, à Antiguidade, isto é, às suas tradições políticas e pré-filosóficas; e, certamente, não por amor à erudição e nem mesmo pela continuidade de nossa tradição, mas simplesmente porque uma liberdade vivenciada apenas no processo de ação e em nada mais [...] nunca mais foi articulada com a mesma clareza clássica" (Entre o Passado e o Futuro, p.213).

Como vimos acima, as concepções políticas antigas - tais como o significado de isonomia, de polis, os dois sentidos de ação nas línguas grega e latina, a metáfora que compara o agir com a arte de tocar flauta - foram os fundamentos para a autora formular o que é ação e sua relação com a liberdade.

Além das concepções antigas, Arendt interpreta de forma particular uma passagem de Agostinho e algumas ideias cristãs para adicionar certas características ao seu conceito de liberdade. ${ }^{62}$ Embora a autora recuse liberdade como livre arbítrio, ela encontra no pensamento agostiniano a ligação entre liberdade e início. De acordo com ela, o pensador cristão também indica, na obra $A$ cidade de Deus, uma liberdade que aparece no mundo. Nas palavras de Arendt: "a liberdade é concebida aqui não como uma disposição humana interna, mas como um caráter da existência humana no mundo" (Entre o Passado e o Futuro, p. 215).

A autora interpreta a afirmação de Agostinho “[...] o homem é livre porque ele é um começo" (Arendt, Entre o Passado e o Futuro, p. 216) no sentido de que Deus, ao criar o homem, teria introduzido no mundo a liberdade como a possibilidade de novos inícios. Para Arendt, ao contrário do que afirma o pensador cristão, a liberdade não está relacionada exclusivamente com a faculdade da vontade, mas ao começo de algo que nunca existiu no mundo antes. Nesse sentido, é porque o homem é um começo que ele pode introduzir algo de novo no mundo, ou seja, mudar a realidade existente. No nascimento de cada homem, a possibilidade de um novo começo é reafirmada potencialmente, pois cada novo ser humano que nasce pode adentrar no espaço público e renovar o mundo.

Arendt se apropria desta passagem de Agostinho ao relacionar a criação do homem com a experiência da fundação romana: cada novo nascimento reafirmaria a aparição da

\footnotetext{
${ }^{62}$ A autora trata de liberdade a partir da tradição cristã na última parte do ensaio "Que é liberdade?", p. 213220.
} 
novidade, assim como cada ação dos cidadãos romanos reafirmava a fundação da cidade livre: "Agostinho [...] nessa parte de sua obra formulou a experiência política central na Antiguidade romana, ou seja, a liberdade qua começo se torna manifesta no ato de fundação" (Arendt, Entre o Passado e o Futuro, p. 216).

A leitura de Agostinho que Arendt apresenta no fim do artigo “Que é liberdade?” é semelhante à sua leitura de Maquiavel: ela não comenta a doutrina do autor cristão como um todo, mas retira uma parte do contexto da obra. Nesta leitura, a autora não analisa ou leva em conta o problema agostiniano da queda, nem considera as diferenças entre a cidade de Deus e a cidade dos homens. A distinção agostiniana entre a cidade divina e a terrestre e o tema da queda desvalorizam a participação nos assuntos políticos e valorizam o diálogo interior. Arendt, ao vincular a criação do homem com liberdade, desconsidera os elementos do pensamento de Agostinho que trazem obstáculos para a liberdade política. ${ }^{63}$

Em outras palavras, a leitura arendtiana de $A$ cidade de Deus não analisa o impacto da teoria agostiniana na vida política, mas serve apenas para refletir sobre a diferença entre o nascimento biológico do homem e sua aparição no mundo público, isto é, sobre a distinção dos homens como seres no mundo e como seres do mundo. A partir desta leitura, Arendt pode conceber a atividade política e a entrada na esfera pública como um segundo nascimento. Na concepção da autora, os homens não nascem livres, mas nascem para a liberdade na medida em que seu aparecimento no mundo é um início.

Além de relacionar nascimento e liberdade, Arendt recorre à tradição cristã para encontrar algo que tenha a mesma potência que a liberdade política. Para tanto, retira todos os elementos sobrenaturais do milagre e encontra uma definição que serve como analogia para a livre ação humana. Os milagres “[...] devem ser sempre: interrupções de uma série qualquer de acontecimentos, de algum processo automático, em cujo contexto constituam o absolutamente inesperado" (Arendt, Entre o Passado e o Futuro, p. 217).

Os processos históricos, embora sejam postos em movimento pela ação humana, podem se tornar automáticos, fazendo parecer que o curso da história é determinado e

\footnotetext{
${ }^{63}$ Bignotto trata da influência de Agostinho para a desvalorização da atividade política na seguinte passagem: "O fundamental, entretanto, é que se aceitou de forma mais ou menos geral a distinção agostiniana entre a Cidade de Deus e a Cidade Terrestre, o que, em última instância, conduziu à ideia de que nenhuma forma superior de existência podia se conciliar com as atividades levadas a cabo no tempo dos homens e em suas cidades" (Bignotto, Pensar a República, p. 50).
} 
necessário. Entretanto, a ação livre, de forma análoga ao milagre, pode interromper este decurso histórico para estabelecer uma nova época.

Levando isso em consideração, entendemos que Arendt indica graus de liberdade distintos: a escolha de adentrar ou não em uma arena pública, a liberdade para debater e trocar opiniões, para ver e ser visto, para discursar e ouvir, a liberdade de deliberar sobre os rumos do mundo e a liberdade de interromper o curso dos acontecimentos para estabelecer uma nova época.

Nessa perspectiva, liberdade e milagre podem ser comparados na medida em que são entendidos como uma interrupção inesperada no fluxo dos acontecimentos.

"O milagre da liberdade está contido nesse poder-começar que, por seu lado, está contido no fato de que cada homem é em si um novo começo, uma vez que, por meio do nascimento veio ao mundo que existia antes dele e vai continuar existindo depois dele" (Arendt, O que é Política, p. 43).

Nesse sentido, Arendt usa a tradição cristã ao formular seu conceito de liberdade para, primeiro, mostrar que cada homem tem a potencialidade de agir e com isso iniciar algo e, segundo, para demonstrar a potência da liberdade em seu mais alto grau: a liberdade enquanto interrupção da história e a fundação de uma nova época [new era].

\subsection{Liberdade e novo início}

A tradição cristã ofereceu para a autora um fundamento teórico para tratar da questão do início e da liberdade como milagre, contudo, a base histórica para tratar destas questões são as revoluções. Dito de outra forma, a fundação de algo que nunca existiu e o início de uma nova época só foram formulados enquanto experiência a partir das revoluções modernas. Embora a autora cite a questão do início em Agostinho e use o milagre como metáfora para tratar de liberdade, como vimos anteriormente, na Antiguidade clássica a vida política comportava mudanças, mas não estava relacionada com novos começos, com uma interrupção na história. Além disso, as mudanças na política se davam dentro de formas de governo conhecidas: a concepção de anacilose indica isso. Já na tradição cristã, o novo surge no mundo com o nascimento de Cristo, isto é, o novo surge pela vontade e intervenção divina, não surge por meio da ação humana. 
Sobre a mudança na concepção de tempo e história, o artigo de Bignotto "O círculo e a linha" é esclarecedor. Para o autor, o pensamento no renascimento produziu uma abertura para a reflexão sobre uma nova teoria da história ao contrapor a concepção de história cristã e recuperar a noção de história antiga.

De acordo com Bignotto, a imagem do tempo na tradição cristã é a linha: começa com a criação, é marcada pelo nascimento de Cristo e termina com o Juízo Final. Nesta perspectiva, o transcorrer da história não é modificado pelas atividades mundanas e seu significado não depende dos homens, é revelado por Deus e só será completamente desvelado no Juízo Final. ${ }^{64}$ Santo Agostinho, para tratar desta questão, divide o tempo e a história em dois: sagrado e secular, sendo o primeiro mais importante e valorizado. Para Bignotto:

"O dualismo agostiniano, que se experimenta tanto na separação da história quanto na separação do tempo, resultou numa forte depreciação das atividades puramente humanas tais como a política. Se o aiôn outos, o tempus dos homens, era um mero intervalo na eternidade (aeternitas), tudo o que fazemos durante nossa permanência na terra tem pouco significado do ponto de vista de Deus. Essa desqualificação do tempo humano passou a sofrer fortes ataques a partir do final do século XII." (Tempo e História, p. 182).

Nesse sentido, o retorno à imagem de tempo dos antigos - o círculo - significava o rompimento com a dualidade de tempo cristão e a valorização das atividades humanas. A cidade deixa de ser entendida como o lugar da condenação sofrida em razão do pecado original e se torna o lugar onde a natureza humana pode se desenvolver e produzir belos feitos. ${ }^{65} \mathrm{O}$ tempo cíclico é representado pela figura da Fortuna, que "pode apenas fazer girar a roda que está em seu poder, mas não criar algo novo uma vez que o mundo está condenado à eterna repetição" (Bignotto, Tempo e História, p. 186). A deusa Fortuna, diferentemente da providência divina no cristianismo, deixa espaço para a ação humana vencê-la. A história, nesta perspectiva, não é determinada por ela, os homens têm a potência de influenciá-la.

No Renascimento, a ação é revalorizada e a história passa a ser fruto dos atos dos homens. No entanto, a imagem da Fortuna não comporta rompimentos na história nem a fundação do novo. Somente com as revoluções modernas o novo início, a interrupção no

\footnotetext{
${ }^{64}$ Conferir em Tempo e História, p. 177.

${ }^{65}$ Ver em Tempo e História, p. 186.
} 
decurso dos acontecimentos históricos, está ligado com a ação dos homens. Ainda, somente na fundação revolucionária a criação de um novo sistema de poder passa a ser entendida como possível. Como já mencionamos anteriormente, na Antiguidade, as formas constitucionais eram bem conhecidas - politeia, democracia, aristocracia, oligarquia, monarquia e tirania - e se repetiam ciclicamente. Em Aristóteles, por exemplo, a única forma de retardar este movimento cíclico seria por meio dos regimes mistos. Segundo Bignotto, os humanistas cívicos, assim como Políbio, também acreditavam que as formas mistas seriam melhores que as formas particulares, pois elas são mais capazes de deter a marcha da corrupção, são mais estáveis e duradouras. ${ }^{66} \mathrm{Com}$ isso, somente com os eventos revolucionários os homens passam a conceber a criação de corpos políticos inteiramente novos, não baseados nas formas constitucionais antigas e tradicionais. Na perspectiva arendtiana, a concepção de liberdade sofreu alteração com os eventos revolucionários: somente a partir deles a liberdade pode ser relacionada metaforicamente com milagre.

O que as revoluções modernas tornaram claro é que a fundação de uma nova época é fruto da atividade política. Isso não quer dizer que somente a Modernidade contou com a experiência da fundação, mas, de acordo com Arendt, a fundação se deu em plena luz do dia pela primeira vez com as revoluções do século XVIII. Os mitos de fundação seriam prova disto: as fundações antigas não foram tratadas pelo pensamento político, mas por mitos como o êxodo das tribos de Israel e a história de Virgílio sobre Eneias. ${ }^{67}$ Pode-se questionar que as fundações antigas foram tratadas somente por meio de mitos ao olharmos para os escritos de Cícero e Tito Lívio. ${ }^{68}$ Ambos trataram da fundação de Roma e procuraram minimizar o papel das lendas e mitos na reflexão sobre a formação da república. Diferentemente de Arendt, estes autores romanos entendem que fundar uma república envolve a ação de muitas gerações: a República romana começou a se formar com Rômulo e se completa com a forma mista com a criação dos tribunos da plebe. Nas palavras de Cícero:

"Porém, nossa república não foi constituída pelo engenho de um, mas de muitos, nem durante a vida de um homem, mas em alguns séculos e gerações. Pois [Catão] dizia jamais ter existido um engenho tão grande - alguém a quem nada escapasse - e que nem todos os engenhos reunidos em um só poderiam

\footnotetext{
${ }^{66}$ Conferir em Tempo e História, p. 187.

${ }^{67}$ Ver em Sobre a Revolução, p. 262 e 263.

${ }^{68}$ Especificamente o livro II de De Republica e os Livros II e III de História de Roma.
} 
prever tanto, [a ponto de] abarcar em apenas um momento tudo, sem a experiência das coisas e sem amadurecimento" (Cícero, De Republica, livro II, 2. $)^{69}$

Enquanto para os autores antigos a fundação se desenrola em um longo período de tempo, para Arendt a fundação se dá com a constituição de um novo corpo político. No Novo Mundo, a constituição de um novo corpo político durou 13 anos, já na França, o ato de constituir o novo corpo político foi mais complicado devido ao número de Cartas Constitucionais que se sucederam, de uma maneira geral, de 1789 a 1793 . Neste período, a criação de um novo sistema de poder foi intensamente discutida, mas nenhuma Constituição duradoura foi estabelecida. Assim, é possível identificar uma mudança na concepção de fundação com o advento das revoluções: se na Antiguidade as fundações eram feitos de muitas gerações, na Modernidade a fundação do novo surgiu em poucos anos. Nesse sentido, foram nas revoluções modernas que a liberdade coincidiu com a fundação de algo que nunca existiu antes, com a criação de uma nova época.

Além das revoluções terem modificado a concepção de fundação, modificaram também a noção de liberdade. Como visto acima, Arendt apresenta liberdade como um conceito complexo e multifacetado: que possui pré-condições, espaço delimitado, está ligado com a ação, participação nos assuntos públicos, ou ainda como novos inícios. De maneira resumida, pode-se dizer que a pré-condição da liberdade é estar liberto das necessidades do corpo e estar livre do domínio de outrem. O lugar da liberdade é o espaço público, onde uma igualdade artificial pode ser estabelecida para que os homens possam falar e agir com isonomia. Nessa perspectiva, a liberdade se manifesta na ação, significa participar dos assuntos públicos. Toda esta definição de liberdade foi baseada na experiência da polis grega e da República romana e foi confirmada pela experiência revolucionária na Modernidade. Contudo, o sentido mais radical de liberdade, a fundação de uma nova época, só surgiu com as revoluções.

Em outras palavras, embora as revoluções tenham surgido graças ao gosto pela liberdade entendida como os antigos a definiam, os revolucionários a experimentaram não apenas como o direito de participar do governo, mas também como fundação de um novo início. A liberdade, na perspectiva revolucionária, passou a significar também a

\footnotetext{
${ }^{69}$ Tradução de Bernardo, O De Republica de Cícero: natureza, política e história, p.122.
} 
constituição de um novo sistema de poder. Historicamente falando, a fundação dos Estados Unidos da América e o surgimento dos sistemas de conselhos desde as revoluções do século XVIII até as revoluções do século XX têm indicado o novo significado de liberdade - a interrupção do fluxo dos acontecimentos para o estabelecimento de um novo início, especificamente, o novo surge com a fundação de um novo sistema de poder que não é determinado pela forma de governo precedente.

Nesse sentido, o conceito de liberdade em Arendt possui uma historia na medida em que se alterou com o surgimento das revoluções modernas. Importa notar que a mudança na concepção de liberdade não é apontada no ensaio “Que é liberdade?”. Neste texto a autora entra em debate com a tradição filosófica que entendia liberdade enquanto livre-arbítrio e enquanto liberdades individuais. Ela demonstra como a concepção de liberdade muda com a mudança no espaço público e privado: enquanto a pólis grega e a civitas romana resguardavam um espaço onde os cidadãos podiam agir, a liberdade era ligada à política; com a redução do espaço público-político na Antiguidade tardia, a liberdade passou a ser entendida como faculdade da vontade, sua morada parecia ser o interior do sujeito; na Modernidade e na Contemporaneidade, a valorização da fabricação e do trabalho juntamente com as experiências de dominação e terror no espaço público (regimes tirânicos e totalitários), o exercício das atividades privadas se tornou o lugar da liberdade entendida enquanto independência individual. Nesse sentido, Arendt, no artigo dedicado à liberdade, parece fazer uma espécie de história deste conceito na tradição filosófica e questiona esta tradição ao retomar as experiências e concepções antigas para indicar o significado político de liberdade.

Já em Sobre a Revolução, Arendt entra em debate com a tradição revolucionária, isto é, com os intérpretes das revoluções. Como vimos anteriormente, para a autora, os eventos revolucionários não podem ser compreendidos por meio de conceitos tradicionais como guerra, revolta, golpe de Estado etc. Ainda, de acordo com ela, a revolução não se resume em garantir liberdades civis e instituir um governo limitado. Os homens da revolução tinham apreço pela liberdade política e por isso buscaram fundar um corpo político onde a participação nos assuntos públicos fosse possível. Para instituir este novo corpo político, eles se tornaram conscientes de que teriam que romper com as formas de governo passadas e teriam que se lançar em um novo empreendimento: constituir 
instituições e regras de convivência entre os cidadãos que nunca haviam existido antes. No contexto revolucionário, diversos conceitos, tais como libertação e liberdade, ganharam novos sentidos. Como já foi tratado anteriormente, libertação se tornou mais do que estar livre do arbítrio de alguém ou de um governo, passou a significar ausência de impedimento para se adentrar no espaço público. O conceito de liberdade se tornou mais do que isonomia e participação nos assuntos públicos para corresponder também à fundação de um novo corpo político, de uma nova era. Nesse sentido, o livro Sobre a Revolução, ao tratar da historicidade da palavra "revolução", acaba por apontar um deslocamento de diversos conceitos políticos.

\subsection{As interpretações das revoluções no século XIX}

Como já foi mencionado, Arendt, no começo do primeiro capítulo de Sobre a Revolução, traça a origem e mudança no uso do termo revolução da Antiguidade até o século XVIII para formular seu conceito. Mais adiante, ao final deste mesmo capítulo, a autora continua a indicar a historicidade da palavra ao mostrar como os eventos revolucionários foram interpretados no século XIX e no começo do XX. Para a autora, estes eventos foram mal compreendidos. Com o objetivo de combater a interpretação hegemônica das revoluções em seu tempo, ela entrou em debate com a tradição revolucionária, que, para falar de forma resumida, concebia a revolução como um acontecimento guiado pela necessidade histórica e pela questão social. ${ }^{70}$ Nesse contexto,

\footnotetext{
${ }^{70}$ É importante aqui diferenciar a emergência da questão social da ascensão do domínio social ou da sociedade. A sociedade é um domínio híbrido que mistura o privado e o político: a administração e a questão da sobrevivência, que na Antiguidade pertenciam ao domínio do lar, tornam-se questões públicas (Ver em $A$ Condição Humana, p. 46). Em outras palavras, o trabalho, seus problemas e dispositivos passam a ser organizados publicamente, pois a comunidade política, do ponto de vista da esfera social, consiste em uma grande família cujos assuntos requerem a administração dos bens e da riqueza (Conferir em $A$ Condição Humana, p. 34). A autora, em A Condição Humana, afirma que a sociedade ingressou no domínio público a partir de organizações de proprietários que exigiam do governo a proteção e o estímulo ao acúmulo de riquezas (Ver em $A$ Condição Humana, p. 83). Nesse sentido, o domínio social surgiu antes das revoluções e originalmente estava ligado à pressão dos ricos sobre o governo.

Por outro lado, em Sobre a Revolução, Arendt mostra que a revolução e a questão social passaram a ser associadas a partir da Revolução Francesa. Quando as penúrias da pobreza foram expostas na cena pública e medidas para sanar o problema da necessidade e da miséria, tornaram-se preocupação pública. No entanto, a esfera social ou a sociedade são anteriores a 1789.
} 
Arendt discute principalmente a tradição marxista, que entenderia que o objetivo da revolução consiste em promover uma mudança radical na esfera social. ${ }^{71}$

É importante lembrar que, de acordo com Arendt, Marx está situado no fim da tradição filosófica. Ele percebeu que depois de alguns acontecimentos que marcaram a Modernidade, notadamente a Revolução Industrial e as revoluções do século XVIII, as categorias tradicionais se tornaram insuficientes para tratar da realidade. Levando em conta que Marx percebeu o esgarçamento da tradição e também refletiu sobre o conceito de revolução, surge a questão: por que a autora não adota muitas de suas categorias e procedimentos para tratar dos eventos revolucionários?

A seguir apresentar-se-á a interpretação que Arednt faz da teoria de Marx e os motivos pelos quais a autora não mobiliza as categorias marxianas para tratar das revoluções.

De acordo com Arendt, Marx colocou a tradição de cabeça para baixo ao analisar os eventos que marcaram a Modernidade: a Revolução Industrial suscitou a reflexão sobre o trabalho como principal atividade humana e as revoluções do século XVIII inspiraram a ligação entre violência, política e história. A reinterpretação das atividades humanas à luz da Revolução Industrial inevitavelmente pôs o trabalho como atividade central em detrimento da ação e da contemplação. Para o autor, trabalho não significa apenas metabolismo com a natureza - a atividade necessária para subsistência, mas também inclui as artes, os afazeres do artesão, do fabricante. ${ }^{72}$ Já as Revoluções Americana e Francesa, as quais fizeram surgir um novo corpo político e uma nova sociedade em meio à violência, levaram Marx a entender a violência como parteira da história. Em outras palavras, o autor interpretou que a ação política, para desencadear a revolução, deve estar ligada à violência.

Conforme Arendt, Marx deslocou a violência, que estava fora da vida política, para dentro dela. Segundo a autora, o uso da violência no pensamento tradicional estava relacionado à tirania ou era considerado a ultima ratio nas relações entre os corpos políticos. Marx contraria isso: para ele, a violência ou a posse dos meios de violência é o que constitui as formas de governo. Além disso, o autor inverteu o lugar onde era possível

\footnotetext{
${ }^{71}$ Conforme Arendt, a concepção de que a política é uma função do social, isto é, a noção de que a ação, revolucionária ou não, está subordinada às questões sociais, não surgiu com Marx, já era uma premissa dos economistas políticos desde a primeira metade do século XVIII (Conferir em A Condição Humana, p. 39).

${ }^{72}$ Conferir em "Karl Marx and the Tradition of Western Political Thought", p. 293,
} 
encontrar a verdade e inverteu também a tradicional hierarquia entre a vida contemplativa e a vida ativa. É o trabalho, não a razão, o principal elemento de sua filosofia. Nesse sentido, é no mundo, não no pensamento contemplativo, que se deve procurar a verdade. ${ }^{73}$ Na perspectiva da autora, Marx desafiou a tradição quando alçou o trabalho à atividade central, contudo, ele buscou uma verdade para compreender a política e nessa medida seguiu o modelo tradicional. Arendt indica as continuidades da tradição no pensamento marxiano no artigo "Karl Marx and the Tradition of Western Political Thought" ao relacionar algumas ideias de Marx, Platão e Aristóteles.

Para ela, Platão considera que o discurso político expressa opinião, algo que, por sua definição, é oposto à verdade. Na concepção platônica, a busca da verdade é essencialmente silenciosa: ela consiste na atividade solitária da contemplação. O diálogo tem a função de promover a verdade, mas não é capaz de alcançá-la. ${ }^{74}$

De forma semelhante, para Marx, o discurso não é considerado parte da ação, mas entendido como ideologia, ou seja, algo que tem como função esconder a verdade. O corpo político para o pensador alemão consiste em uma superestrutura coercitiva que serve à economia e à classe dominante. ${ }^{75}$

Ambos os autores partem da premissa de que aparência e ser não coincidem, portanto, a aparência não pode revelar a essência das coisas. Como foi visto anteriormente, segundo Arendt, agir consiste em uma performance realizada diante de um público, nesse sentido, a política está intimamente relacionada com a aparência. Ora, se a política é a esfera da opinião e da aparência, tanto Platão como Marx procuraram fora da esfera política a verdade. Se, para Platão, o mundo das ideias era o lugar da verdade, para Marx, a essência da economia e da esfera social, o modo de produção e a luta de classes são as categorias que revelam a verdade sobre a atividade política. Nesta medida, Marx segue a perspectiva tradicional ao procurar a razão e a finalidade da política fora das atividades políticas.

De acordo com Arendt, a finalidade da política para Platão é permitir a vida contemplativa, isto é, quando os assuntos públicos são guiados pela razão, eles favorecem

\footnotetext{
${ }^{73} \mathrm{Na}$ concepção de Arendt, a ação, por envolver a troca de opiniões, não desvela uma verdade, mas um significado, que pode ser avaliado pela faculdade de julgar.

${ }_{74}^{74}$ Conferir em "Karl Marx and the Tradition of Western Political Thought", p. 296.

${ }^{75}$ Ver em Sobre a Violência, p. 52.
} 
o ócio necessário à contemplação. ${ }^{76} \mathrm{O}$ julgamento de Sócrates seria a prova de que a má condução dos assuntos da cidade consiste em uma ameaça à filosofia. Já para Marx, a política foi historicamente um instrumento de que a classe dominante se serviu para manter a exploração econômica.

$\mathrm{Na}$ perspectiva arendtiana, Marx, além de procurar a finalidade da ação fora da política, segue Aristóteles ao entender que a finalidade da política consiste em manter a ordem econômica. Para Arendt, Aristóteles reduziu o poder e a política à questão de quem domina e quem é dominado ao dividir os homens na cidade entre governantes e governados. De acordo com a autora, Aristóteles foi o primeiro a afirmar que o interesse entendido como o que é útil para uma pessoa ou um grupo - deve reger os assuntos políticos. $^{77}$ A partir desta vinculação entre interesse e utilidade, as formas de governo passaram a ser relacionadas com grupos sociais e riqueza. Marx se mostra herdeiro do pensamento peripatético ao definir o Estado como instrumento de dominação de classe e ao relacionar o regime político com a classe dominante. ${ }^{78}$ Ainda, Marx, assim como Aristóteles, relacionou luta de classes e política. Para o pensador grego, as formas constitucionais são entendidas de acordo com a classe que governa, por exemplo, a democracia é definida como o governo dos pobres e a oligarquia como governo dos ricos. ${ }^{79}$

Dessa forma, segundo a autora, Marx sofre grande influência do pensamento tradicional. Para ela, ele se rebelou contra a tradição, mas ainda assim, usou referências tradicionais para contestá-la. "A rebelião contra a tradição no século XIX permaneceu estritamente no interior de um quadro de referência tradicional; e, ao nível do mero pensamento [...] somente a radicalização, e não um novo início e reconsideração do passado, era possível" (Entre o Passado e o Futuro, p. 55).

Nesse sentido, Arendt não mobiliza as categorias marxianas para tratar das revoluções, pois as considera ligadas à tradição filosófica. Além disso, a autora critica Marx em dois aspectos: primeiro, a subordinação da política à economia e, segundo, a filosofia da história como modo de análise que o autor adota para interpretar os eventos

\footnotetext{
${ }^{76}$ Conferir em "Karl Marx and the Tradition of Western Political Thought", p. 313 e 315 e em Entre o Passado e o Futuro, p. 146.

${ }^{77}$ Ver em Sobre a Revolução, p. 48.

${ }_{78}^{78}$ Conferir em Entre o Passado e o Futuro, p. 49.

${ }^{79}$ Ver em "Karl Marx and the Tradition of Western Political Thought", p. 275
} 
políticos. Juntos estes dois aspectos fizeram o autor interpretar que o objetivo da revolução está mais ligado à igualdade social do que à liberdade política.

De acordo com Arendt, foi na França, a partir de 1789, que surgiu a "questão social", isto é, o enfrentamento da pobreza na cena pública. Historicamente falando, os pobres, ao emergirem como atores na cena política, lançaram luz sobre o problema da necessidade e do processo vital. Assim, na Revolução Francesa, duas novas concepções emergiram: a de que a pobreza impulsiona os homens a lutar contra a opressão e a de que a miséria pode ser resolvida por meio da política. Segundo a autora, o maior teórico das revoluções, Marx, reuniu mais tarde estas duas concepções e centrou sua teoria política na questão da necessidade.

$\mathrm{Na}$ leitura de Arendt, para Marx, a Revolução Francesa falhou em instituir a liberdade porque não resolveu a questão social. A pobreza, em sua teoria, é interpretada em termos políticos: o conceito de 'exploração' inter-relaciona economia e política, ação e trabalho de uma nova forma. Um regime econômico se estabelece por meio do modo de produção e pela organização do poder político. A pobreza não consiste em um fenômeno natural, mas é produzida pelos homens social e politicamente. Disto decorre que a pobreza pode ser mudada por meio da organização política e econômica. Na concepção de Marx, o governo utiliza os meios de violência para forçar um grupo de homens - os escravos na Antiguidade, os servos na Idade Média e os proletários na Modernidade - a arcar com todo o trabalho necessário para manter vivos todos os membros de uma sociedade ou comunidade e, além disso, priva este grupo da capacidade de agir. ${ }^{80}$

Conforme a autora, Marx, ao entender que o problema da miséria pode ser resolvido por meio da política, conclui que a luta contra o regime absolutista e a constituição de um novo corpo político na Revolução Francesa poderiam ter acabado com a dominação econômica e política.

"Assim, o papel da revolução não era mais libertar os homens da opressão de seus semelhantes, e muito menos instaurar a liberdade, e sim libertar o processo vital da sociedade dos grilhões da escassez, para que ela se convertesse num caudal de abundância. Agora, o objetivo da revolução não era mais a liberdade e sim a abundância" (Sobre a Revolução, p. 98).

\footnotetext{
${ }^{80}$ Ver em Sobre a Revolução p. 95-99.
} 
Segundo Arendt, em seus primeiros escritos, Marx engajou-se em persuadir os pobres a se envolverem na ação política quando afirmou que a pobreza não era provocada pela escassez, mas pela violência e por um elemento associado à política, a dominação. Entretanto, nos textos posteriores ao Manifesto Comunista, ele teria desvalorizado a ação ao subordinar a atividade política à economia, ao reduzir a questão da liberdade à igualdade social. Nas palavras da autora: "Politicamente, esse desenvolvimento o levou a uma rendição efetiva da liberdade à necessidade" (Arendt, Sobre a Revolução, p. 99).

Na perspectiva arendtiana, Marx se colocou em uma posição ambígua com relação à liberdade. De um lado, desenvolveu uma teoria sobre a relação entre os grilhões das necessidades vitais, a dominação e o impedimento de acesso à política e com isso visava a impelir os homens a lutar pela liberdade e a se engajarem na atividade política. De outro lado, nos escritos tardios, acabou por enfatizar mais o papel da necessidade nos assuntos humanos e a desvalorizar a política ao subordiná-la ao campo econômico.

"Depois de denunciar as condições sociais e econômicas em termos políticos, logo Marx deve ter se apercebido de que suas categorias eram reversíveis e que, teoricamente, também seria possível interpretar a política em termos econômicos" (Arendt, Sobre a Revolução, p. 98).

Para a autora, essa reversibilidade dos conceitos, do campo econômico para o político e vice-versa, acaba por obscurecer a distinção e especificidade destes campos. Em outras palavras, a interconexão entre as esferas política e econômica acabou por ser entendida como subordinação de uma a outra.

Embora Arendt considere em sua reflexão os escritos de Marx dedicados à economia e à análise de circunstâncias - como "Guerra Civil na França" e "A luta de classes na França" -, ela parece negligenciar o texto mais refinado de Marx no que concerne política e revolução, a saber, O 18 Brumário de Luís Bonaparte. Neste texto, o autor indica que há divisões dentro de uma mesma classe e aponta que os interesses dos grupos sociais são formados politicamente. $\mathrm{Na}$ avaliação dos acontecimentos na França entre 1848 a 1852, Marx, apesar de usar a categoria de classe, mostra que a atuação pública não é definida necessariamente pela estrutura econômica: a burguesia se cinde e apresenta três partidos com interesses distintos. A disputa política se dá entre a pequena burguesia, que acaba ganhando o apoio do proletariado, os latifundiários e os financistas. Luís Bonaparte aproveita este conflito e organiza o lumpen-proletariado para se eleger e se 
manter no poder. Já os camponeses não desempenharam papel relevante uma vez que não estavam organizados publicamente. Nesse sentido, na análise de conjuntura, o método de filosofia da história, a noção de luta de classes entre dominantes e dominados, a sobreposição da economia sobre a política são matizados por Marx. As categorias marxianas no texto $O 18$ Brumário de Luís Bonaparte não se apresentam de forma estanques e fixas, além disso, a articulação pública e a ação política são valorizadas.

Assim, Arendt apresenta uma leitura de Marx que não é equilibrada: a questão econômica, o uso da violência para mudar o mundo e a filosofia da história são destacadas em detrimento de outros elementos.

Para a autora, a noção de que a pobreza não é produzida pela natureza e que por isso pode se lutar contra a opressão das necessidades da vida ganhou uma dimensão teórica sem par pelo pensamento de Marx. Mas, esta noção surgiu no decorrer da Revolução Francesa. É importante mencionar que, de acordo com a autora, a questão social não foi formulada publicamente na Revolução Americana, porém isso não significa que não havia miséria no Novo Mundo. Ela estava presente na forma da escravidão e do trabalho escravo, problema que só foi enfrentado mais tarde, na Guerra de Secessão. Nesse sentido, embora houvesse miséria na América do Norte, este tema não surgiu publicamente durante a revolução. Em outras palavras, os revolucionários do Novo Mundo focaram nas questões políticas: na fundação de um novo corpo político, na instituição de uma nova autoridade e novas leis. Eles não abandonaram o debate em torno da questão da liberdade para sanar o problema da miséria.

Nas palavras da autora:

"Era tão impossível desviar os olhos da miséria e da desgraça da grande maioria da humanidade no século XVIII em Paris ou no século XIX em Londres, onde Marx e Engels iriam refletir sobre a Revolução Francesa, quanto hoje em alguns países europeus, em muitos latino-americanos e em quase todos os asiáticos e africanos" (Sobre a Revolução, p. 109).

A dificuldade em ignorar a miséria na França após 1789 reside no fato de que os homens perceberam que após a queda da monarquia absoluta poucos conquistaram a liberdade, isto é, a libertação da tirania era pré-condição para a liberdade de alguns, mas muitos franceses ainda estavam oprimidos pela miséria. Nesse contexto, o objetivo da revolução paulatinamente deixou de ser a criação de instituições e leis da nova república e 
se tornou a administração de bens para promover a igualdade social. A forma política de debate entre os cidadãos em diversas instâncias de participação se mostrou lenta e ineficaz para enfrentar a questão social, por outro lado, a centralização das decisões parecia ser a forma mais rápida para sanar o problema da pobreza. Além disso, a concepção de que uma república deve ter instituições capazes de abarcar e depurar opiniões e interesses plurais foi abandonada na medida em que ganhou força a ideia de que a garantia do bem-estar social era a vontade geral do povo. Para a autora, essas mudanças foram parcialmente responsáveis pela centralização do poder, a redução da participação política e o uso de medidas extraordinárias e até mesmo violentas em vista de sanar a questão social. ${ }^{81}$

Contudo, para a Arendt, as ideias e ações políticas não podem promover o bem estar social. Historicamente falando, o desenvolvimento da tecnologia teve mais impacto na vida social. Ele foi responsável pelo aumento na produtividade do trabalho, isso, por um lado produziu mais riqueza e, por outro, promoveu a liberação do trabalho para a dedicação à outras atividades. Em suas palavras: “[...] foi somente o surgimento da tecnologia, e não o surgimento das ideias políticas modernas em si, que veio a refutar a velha terrível verdade de que apenas a violência e o domínio sobre os outros podiam trazer a liberdade a alguns homens" (Sobre a Revolução, p. 157).

Arendt com isso distingue o político do social. Em sua perspectiva, a ação e o debate dizem respeito à liberdade, às relações no espaço público, às instituições e à forma constitucional. Já o trabalho e a economia se relacionam com a necessidade, a distribuição e administração da riqueza. Conforme foi tratado acima, para a autora, usar a forma política para resolver a questão social compromete a sobrevivência: as necessidades do corpo são urgentes, não podem esperar o lento processo de debate ampliado entre pares, o qual envolve a persuasão e troca de opiniões antes da tomada de decisões. Usar a forma administrativa e econômica nas questões políticas compromete a liberdade: administração e economia são ciências, elas estão ligadas à comprovação de teorias, por isso, a fala do especialista é privilegiada e exige hierarquização, aqueles que têm posse do conhecimento decidem e os outros simplesmente executam ordens.

\footnotetext{
${ }^{81}$ Conferir em Sobre a Revolução, p. 130.
} 
Ao reforçar a fronteira entre as esferas política e social, que foram enfraquecidas com o surgimento da questão social na Revolução Francesa e com o pensamento de Marx, Arendt busca esclarecer o sentido, as potencialidades de libertação na Modernidade e o risco da ação ser esquecida em nome da administração. Nesta análise, a autora pouco explora as relações entre as duas esferas. Também em A Condição Humana, a autora menciona certa ligação entre política e economia ao afirmar que as relações de trocas no mercado envolvem mais do que atividades econômicas: o homem econômico é um ser atuante, não se reduz ao produtor, negociante ou mercador. ${ }^{82}$ No entanto, Arendt não desenvolve esta questão.

Já em Sobre a Revolução, ao olhar para a política na Antiguidade, a autora formula sua definição preliminar de liberdade e libertação ao mostrar que, antes de participar dos assuntos da cidade, era preciso estar livre das necessidades do corpo. De fato, a escravidão possibilitava a atividade política: o trabalho escravo permitia que os cidadãos se dedicassem aos assuntos da polis porque os livrava das necessidades da vida. Contudo, Arendt não trata, por exemplo, da reforma na legislação que aboliu a escravidão por dívidas em Atenas do século V a.C. e permitiu a ampliação da cidadania. Nesta medida, Arendt não desenvolve a relação entre política e economia que ela mesma reconhece e que foi explicitada por Marx no conceito de exploração. Se a exploração é em parte permitida por instituições políticas que garantem o direito de poucos de dominar economicamente a maioria, este direito pode ser mudado politicamente. Dito de outra forma, o direito pode afetar parte da exploração. Na Revolução Francesa, por exemplo, a extinção dos privilégios de certos estamentos e a desapropriação de terras da Igreja deslegitimaram politicamente a dominação da nobreza e do clero. Michelet atesta que um dos primeiros resultados da revolução na França foi a melhoria da vida dos pobres, algumas medidas políticas tais como a supressão do dízimo e dos impostos indiretos, a venda de terras do reino por menos da metade do preço melhoraram a questão social. ${ }^{83}$

É certo que estas medidas não sanaram completamente a questão social, isto é, não promoveram a redistribuição de riqueza e a garantia de sobrevivência para todos os franceses. Mesmo assim, a partir disso, é possível notar que o debate público pode gerar o

\footnotetext{
${ }^{82}$ Ver em A Condição Humana, p. 232.

${ }^{83}$ Conferir em História da Revolução Francesa, p. 99.
} 
senso compartilhado de que a miséria é uma injustiça inaceitável e a ação pode criar instituições e leis que dificultam e combatam a exploração.

Ainda, a autora, em Sobre a Revolução, afirma que o desenvolvimento da tecnologia gera a liberação do trabalho. Entretanto, em A Condição Humana, a autora indicara que o advento da automação tinha a potência de liberar a humanidade de seu fardo mais antigo: o trabalho e a necessidade. Mas com a valorização do trabalho e a ascensão da mentalidade do animal laborans, os homens modernos dificilmente se engajam em outra atividade. Em suas palavras: "A era moderna trouxe consigo uma glorificação teórica do trabalho, e resultou na transformação factual de toda sociedade em uma sociedade trabalhadora" (A Condição Humana, p. 5). Levando isso em conta, vê-se que o desenvolvimento tecnológico não gera automaticamente a liberação do trabalho e não estimula necessariamente os indivíduos a se dedicarem à política. A tecnologia teria um potencial emancipatório que não se concretizou, em grande medida porque outros eventos, o campo das ideias e a mentalidade influenciaram a hierarquia das atividades humanas.

A partir desta discussão é possível analisar os limites e ganhos da distinção arendtiana entre o social e o político. Tal distinção, segundo Benhabib, não leva em conta que a esfera da necessidade é permeada por relações de poder. Por exemplo, tanto a distribuição do trabalho como a de recursos envolve poder, por isso, a economia não é neutra nem apolítica. ${ }^{84}$ Por um lado, nesta crítica, a comentadora negligenciou a distinção entre poder e dominação na pensadora alemã, pois, nos termos de Arendt, a economia, o social e o privado são permeados por relações de dominação, as quais envolvem violência e hierarquia, mas não envolvem poder, que, para a pensadora alemã, significa a ação em conjunto. Por outro lado, Benhabib destaca nesta passagem uma importante questão: economia e política são conceitos diferentes, mas isso não significa que eles não tenham relação entre si. Mesmo Arendt reconhece esta relação quando afirma que, para ser livre, é preciso estar entre pares, não estar sob a dominação de outrem e sob o jugo da necessidade. No entanto, ela não trata da forma de se libertar de toda a dominação. Dito de outra forma, a autora não esclarece bem seus leitores sobre como seria possível revalorizar a ação na Modernidade e como seria possível liberar os homens para a atividade política quando a vida biológica se torna a principal preocupação pública. Estes esclarecimentos não

\footnotetext{
${ }^{84}$ Ver em The Reluctant Modernism of Hannah Arendt, p. 138-141.
} 
poderiam estar no plano meramente de um "dever ser" geral, mas extraídos das experiências históricas.

A distinção de Arendt entre social e político, uma vez que ela nos alerta para dois problemas: por um lado, a preocupação excessiva com a economia e o social pode levar ao governo de especialistas ou a um despotismo esclarecido e acabar com a participação ampliada, e, por outro lado, a política não pode sanar por completo a miséria. Dessa forma, importa mais explorar as relações, aproximações e tensões entre social e político do que desfazer a distinção destes conceitos.

Como vimos, Arendt explora mais a tensão entre estes conceitos do que suas interrelações. Para dizer de outro modo, a autora enfatiza as diferenças entre o político e o social e os riscos que a preocupação com o social traz à esfera política e deixa de aprofundar a conexão entre liberdade e liberação, entre administração da riqueza e possibilidade da ação nas revoluções. Esta ênfase na distinção e tensão entre os conceitos foi provavelmente motivada pela ideia hegemônica nos tempos de Arendt de que revolução significa promover a transformação social por meio da centralização do poder e do uso da violência.

De acordo com a autora, a influência de Marx na tradição revolucionária merece ainda maiores explicações, mas certamente seus escritos influenciaram a concepção de revolução a partir do século XIX. Para ela, a insistência de Marx em prestar mais atenção à questão social em detrimento da reflexão sobre as questões de Estado e à forma do corpo político o levou a não refletir detidamente sobre a novidade revolucionária - o sistema de conselhos da primeira comuna de Paris na Revolução Francesa - e a defender a concepção de ditadura do proletariado, que deteria o monopólio do poder e da violência. ${ }^{85}$

\subsection{Filosofia da história e revolução}

Arendt, além de debater com Marx a respeito da subordinação do político ao econômico e da definição de revolução como questão social, critica o autor por tratar os eventos passados por meio da filosofia da história. Para a autora, Hegel inaugurou a

\footnotetext{
${ }^{85}$ Conferir em Sobre a Revolução, p. 324.
} 
filosofia da história, a qual consistiu numa maneira de enfrentar a separação entre o mundo das aparências e o mundo das ideias e em uma maneira de escapar da crise da tradição. Por um lado, a filosofia da história reuniu aparências e ideias eternas, realidade empírica e razão, isto é, história e verdade em um todo coerente: ${ }^{86}$ a história passou a ser vista como um processo de desenvolvimento contínuo, como uma cadeia de acontecimentos cujo sentido deve ser encontrado no todo. A figura da coruja de minerva, ${ }^{87}$ de acordo com a autora, simboliza a visão hegeliana da história como objeto de reflexão filosófica: a passagem em que a ave alça voo ao cair da noite significa que, no fim de uma era, a verdade se revela. E, ao saber a verdade, a coruja pode anunciar o amanhecer, isto é, entender o sentido e o telos da história. Assim, a filosofia da história procura uma lei que explique o sentido e a causa do desenvolvimento histórico. Esta lei pode ser identificada pelo filósofo na medida em que a história se desenvolve de acordo com o espírito.

Por outro lado, a filosofia da história foi uma forma de tratar o passado no contexto de crise da tradição. Para Arendt, o fio condutor que ligava os homens ao passado e a forma tradicional de avaliar os eventos pretéritos se desgastou na Modernidade. Nesse momento, alguns filósofos buscaram na filosofia da história uma nova forma de tratar o passado. Em suas palavras: "O fio da continuidade histórica foi o primeiro substituto para a tradição [...]" (Entre o Passado e o Futuro, p. 55).

$\mathrm{Na}$ perspectiva arendtiana, explicar as revoluções por meio da filosofia da história significa interpretar os eventos revolucionários como consequência de um desenvolvimento histórico necessário e irresistível. Ora, se há uma lei que explica o movimento da história e a revolução é consequência deste movimento, os eventos revolucionários se deram à revelia das intenções e escolhas dos agentes. Dito de outra maneira, a concepção de uma marcha ou tendência histórica está fundamentada na ideia de que há uma lei orientadora dos rumos da história que está para além das consciências dos agentes e dos fatos vistos na esfera pública. Esta concepção de história tem como objetivo conhecer o processo geral que causou um evento, não busca compreender o seu significado.

\footnotetext{
${ }^{86}$ Ver em "Karl Marx and the Tradition of Western Political Thought", p. 308.

${ }^{87}$ Conferir em "Karl Marx and the Tradition of Western Political Thought", p. 279.
} 
Para a autora, na concepção antiga, ao contrário, a história era entendida como um conjunto de eventos singulares, cada um com seu significado particular, os quais indicam os grandes feitos dos homens e as potencialidades e perigos da ação humana. Levando em conta esta concepção, a autora entende que as revoluções não eram necessárias, mas foram fruto da ação em conjunto e das escolhas dos homens.

Conforme Arendt, a noção de "irresistibilidade" perpassa a teoria revolucionária hegemônica. O termo revolução em seu sentido astronômico não era relacionado com os feitos humanos, mas indicava que os astros descreviam um movimento irresistível, que não podia ser alterado. Para Arendt, esta noção de "movimento irresistível" foi preservada no uso do termo revolução com o surgimento da filosofia da história. ${ }^{88}$ Nesse sentido, a autora acrescenta aqui mais um momento na historicidade do termo revolução. Se no século XVIII a revolução foi considerada uma ruptura na história para a fundação de uma nova época, no século XIX, com a filosofia da história, a revolução passou a ser entendida como um acontecimento necessário que, entre outros, revela o sentido da história. Dito de outra forma, o termo passa do campo político para o histórico.

Arendt afirma que, para Hegel, a Revolução Francesa indicaria que o absoluto, algo que na tradição da filosofia política se encontrava no mundo das ideias, teria dado mais um passo importante no sentido de sua efetivação nos assuntos humanos. De acordo com ela, a filosofia hegeliana descreve e entende aquilo que ocorria no mundo humano do ponto de vista do espectador. Já o ponto de vista do agente não é levado em consideração. Principalmente para o espectador, aquele que lança um olhar retrospectivo, a Revolução Francesa aparece em termos de necessidade histórica.

"Diante do olhar retrospectivo do pensamento, tudo que havia sido político ações, palavras e acontecimentos - se tornou histórico, daí resultando que o novo mundo que fora pronunciado pelas revoluções setecentistas não recebeu 'uma nova ciência política' como ainda reivindicava Tocqueville, e sim uma filosofia da história [...]" (Arendt, Sobre a Revolução, p. 84).

Segundo a autora, o movimento histórico dialético de Hegel, movido pela necessidade e liberdade, carrega um paradoxo: a liberdade surge da necessidade. Para Arendt, a noção de necessidade histórica confere aos assuntos humanos uma regularidade e universalidade, as quais tentam livrar o mundo da contingência própria da ação em

\footnotetext{
${ }^{88}$ Conferir em Sobre a Revolução p. 83.
} 
conjunto, que envolve escolhas e intenções de diversos agentes. Além disso, a noção de necessidade histórica visa a dispensar as diversas narrativas e perspectivas de um mesmo evento para dar lugar a uma única narrativa que parece ser mais confiável por ser baseada em uma lei universal. ${ }^{89}$

$\mathrm{Na}$ concepção de Arendt, a dificuldade para entender que a ação na Revolução Francesa não foi fruto da necessidade histórica reside na própria natureza da ação. A ação engendra uma pluralidade de atores de forma que é difícil reconhecer a contribuição de cada um na revolução. Até mesmo os atores que fizeram a revolução surgir se espantaram com a potência de seus atos. A potência da ação pode, por isso, parecer algo fora das capacidades humanas individuais. Esta característica da ação somada à forma moderna de olhar para o passado, a qual procura leis universais, levaram alguns teóricos a entender a fundação do novo nas revoluções como consequência de um processo histórico inevitável, o qual se desenrola em boa medida à revelia dos agentes e os arrasta a um determinado momento histórico.

$\mathrm{Na}$ perspectiva arendtiana, com Hegel, a noção de necessidade histórica assenta suas bases no olhar retrospectivo sobre a Revolução Francesa. Com Marx, a noção de necessidade também passa a carregar uma dimensão da realidade biológica, a saber, a necessidade de manter um organismo vivo, a necessidade de sobrevivência. Em outras palavras, a autora indica que no século XIX o temo revolução sofre duas alterações: a partir de Hegel o termo é deslocado da esfera política para a filosofia da história e com Marx é novamente deslocado, passa para o campo social, mas sem deixar completamente o sentido histórico.

Segundo Arendt, "O ponto essencial é que a Filosofia Política de Marx não se baseava sobre uma análise de homens em ação, mas, ao contrário, na preocupação hegeliana com a História" (Entre o Passado e o Futuro, p. 112). Nesse sentido, Marx procurou na história uma lei que explicasse o sentido do movimento histórico. Nas palavras da autora: "A luta de classes: para Marx essa fórmula parecia desvendar todos os segredos da história, exatamente como a lei da gravidade parecera desvendar todos os segredos na natureza" (Entre o Passado e o Futuro, p. 115). A luta de classes como motor da história coloca o trabalho e a questão da sobrevivência em primeiro plano, nessa

\footnotetext{
${ }^{89}$ Ver em Sobre a Revolução, p. 87.
} 
concepção, o mais importante na revolução é a resolução da questão social. Além disso, numa perspectiva da filosofia da história, o fim de um acontecimento pode ser confundido com o sentido e com a finalidade da ação: o decurso do acontecimento aponta para seu sentido e o sentido da história é transformado em finalidade da atividade política. No caso da Revolução Francesa, seu curso consistiu na paulatina obliteração da questão da liberdade, ligada com a instituição da república, em favor da igualdade social. Desta forma, do ponto de vista da filosofia da história, a igualdade e a questão social se tornaram o sentido da revolução e a finalidade da ação.

O historiador dos conceitos, Koselleck, embora não tenha tratado do diálogo que Arendt trava com Marx, ajuda a esclarecê-lo ao estudar as mudanças no significado e usos do conceito de revolução e de história. Ele, assim como Arendt, também indica a passagem do termo revolução da astronomia para a política. Para Koselleck, o termo revolução, quando se referia a um movimento cíclico, engendrava uma análise política de longo prazo que visava a refletir sobre diversas mudanças de governo e de forma de governo.

De acordo com o autor, mesmo com os iluministas, o termo ainda se referia a uma investigação que levava em conta um longo período de tempo, pois eles estavam interessados em analisar as grandes transformações nos costumes, direito, religião, economia, nação e Estado. ${ }^{90}$

Somente depois de 1789, o termo revolução adquire um outro sentido: a partir da experiência de criar um novo calendário, com a emergência da ideia de que era possível estabelecer uma nova era, a revolução passou a ser definida como uma mudança radical que ocorria em um curto espaço de tempo. Segundo Koselleck, isto levou a uma outra forma de análise dos eventos. A investigação, a partir de então, compreende um curto prazo de tempo e procura uma ruptura com o passado, uma mudança radical e rápida na estrutura política e social. ${ }^{91}$ Nesse sentido, até a Revolução Francesa, a palavra revolução era usada para designar, de um lado, um fenômeno natural e, de outro, um político, mas não uma mudança social. Depois de 1830, diversos pensadores, dentre eles Tocqueville e Marx, levam adiante a fórmula da revolução em termos de mudança social, de modo que o

\footnotetext{
${ }^{90}$ Ver em Futuro passado, p. 67.

${ }^{91}$ Conferir em Futuro passado, p. 69.
} 
termo revolução em nossos dias é usado mais no sentido de transformação profunda na estrutura social e o sentido político do termo perdeu força.

Levando em conta a constatação de Koselleck de que o termo revolução ganhou conotações fortemente sociais, fica mais clara a insistência da autora no sentido político do termo e a sua separação entre as esferas social e política. Além disso, esta constatação elucida a razão pela qual Arendt entra em debate com Marx.

Ainda de acordo com Koselleck, após 1789, a palavra revolução se tornou um "coletivo singular", ou seja, um termo que cristalizou em si todas as trajetórias das revoluções particulares e também se transformou em um princípio regulador que ordena tanto o conhecimento quanto a ação política. ${ }^{92}$ Nessa perspectiva, a Revolução Francesa se tornou um modelo e seu curso passou a influenciar tanto o olhar do historiador quanto os homens envolvidos em revoluções posteriores. Para o autor, o próprio conceito de história se alterou depois da Revolução Francesa. Este evento reorganizou a relação entre passado e futuro.

Segundo Koselleck, a história, desde a Antiguidade, era uma espécie de estoque de experiências alheias, das quais os homens poderiam se apropriar com um objetivo pedagógico, isto é, eles olhavam para o passado para guiar sua ação no presente. Segundo o autor, esta concepção de história foi expressa por Cícero com o topos Historia magistra vitae. Ainda no início da Modernidade, esta noção de história como mestra da vida permanecia. Para Maquiavel, por exemplo, os homens de seu tempo deveriam se inspirar em grandes exemplos do passado. ${ }^{93}$

Já em 1789, quando um acontecimento sem precedentes históricos ocorreu, os homens não puderam encontrar situação semelhante no passado para guiar sua compreensão e ação. Nesse contexto, a história deixou de ser entendida como um estoque de experiências exemplares. De acordo com Koselleck, esta mudança no conceito de história fica evidente na língua alemã: o termo historie - que significava relato, narrativa deixa de ser usado e passa a ser empregado o termo Geschichte - o qual consiste em um coletivo singular, reúne as diversas histórias em uma única, por isso, consistiria na História

\footnotetext{
${ }^{92}$ Conferir em Futuro passado, p. 71.

${ }^{93}$ Ver em Futuro passado, p. 42-44.
} 
em si. ${ }^{94}$ A história entendida como Geschichte deve trazer à luz motivos ocultos, extrair dos acontecimentos uma ordem causal. Nesse sentido, a história deixa de ensinar a prudência e virtude passadas que poderiam guiar a ação no presente para se tornar uma ciência que indica as causas e efeitos dos fenômenos e a tendência do processo histórico. Nessa perspectiva, o futuro é planejável, ou seja, é possível que se produza o futuro ao se conhecer o Zeitgeist e a dinâmica de causa e efeito. Vale destacar que, de acordo com Koselleck, os conceitos de filosofia da história e de Geschichte surgiram nas mesmas décadas e são complementares.

Arendt também reconhece a mudança do olhar para o passado e a complementariedade entre a filosofia da história e o conceito moderno de história. De acordo com ela, ambos acabam por negligenciar as particularidades dos eventos revolucionários ao cunharem o termo revolução com base no curso da Revolução Francesa. Além disso, elas obliteraram as questões políticas ao reconhecerem uma tendência ou lei histórica.

Para a autora, as análises de Marx corroboraram para uma nova forma de entender a esfera política. Em suas palavras: "Mais recentemente, sua influência tem sido frequentemente negada. Isto não é, no entanto, porque o pensamento de Marx e os métodos que ele introduziu tenham sido abandonados, antes porque eles se tornaram tão axiomáticos que suas origens não são mais lembradas." ("Karl Marx and the Tradition of Western Political Thought", p. 274). ${ }^{95}$

O pensamento de Marx e sua influência eram temas difíceis de serem debatidos no tempo de Arendt por dois motivos: de um lado, o debate sobre sua teoria foi obscurecido por disputas entre facções e partidos, tanto as disputas entre grupos marxistas, quanto as disputas entre marxistas e anti-comunistas. De outro lado, o fato de o bolchevismo e de o regime stalinista terem se declarado marxistas, contribuiu para obliterar os ensinamentos do autor. Segundo Arendt, neste contexto: "Marxismo é claramente a mais terrível

\footnotetext{
${ }_{94}^{94}$ Ver em Futuro passado, p. 69.

95 "More recently, his influence has been frequently denied. That is not, however, because Marx's thought and the methods he introduced have been abandoned, but rather because they have become so axiomatic that their origin is no longer remembered" ("Karl Marx and the Tradition of Western Political Thought", p. 274).
} 
acusação levantada contra Marx" ("Karl Marx and the Tradition of Western Political Thought", p. 276). ${ }^{96}$

Apesar desta dificuldade, podemos identificar na obra da autora algumas diferenciações entre o pensamento marxiano e a maneira com que ele foi apropriado. Em outras palavras, Arendt trata da influência de Marx no pensamento liberal e de esquerda do século XX. Nesse sentido, a seguir apresentar-se-á o modo pelo qual o método marxiano foi apropriado por marxistas na perspectiva da autora.

De acordo com ela, para Marx, agir significa fazer a história. Nesse sentido, a história é feita à maneira da fabricação, atividade guiada pela categoria de meios e fins na qual o fabricante define os instrumentos e a forma de fazer o objeto produzido a partir da ideia ou do modelo do que se quer produzir. Na concepção de "fazer a história", a ideia que determina o que se deve fazer consiste na finalidade (telos) da história. Em outras palavras, a tendência da história identificada pelo olhar retrospectivo do historiador ou do filósofo torna-se um fim intencional da ação. ${ }^{97}$

Segundo Arendt, a noção de "fazer a história" carrega dois problemas, a saber, a supressão do debate público e da liberdade. Se a finalidade da ação é determinada pelo telos histórico e este é uma verdade incontestável baseada no estudo filosófico ou científico, não há o que ser debatido. O debate público está ligado à troca de opiniões entre pares, à persuasão e à escolha. Já a comprovação de uma verdade compele todos a uma mesma conclusão e está ligada a uma assimetria entre aquele que alcançou a verdade e os demais. Ainda, "fazer a história" requer a relação de mando e obediência, pois os que "fazem" executam um plano previamente determinado.

Aplicada pelos marxistas aos eventos revolucionários, esta concepção produziu a ideia de "fazer a revolução". Como já foi mencionado, a tradição revolucionária tomou como modelo o curso da Revolução Francesa e negligenciou toda a ação que se deu com a

\footnotetext{
96 "Marxism is of course the most formidable charge ever raised against Marx" ("Karl Marx and the Tradition of Western Political Thought”, p. 276). Além desta ligação entre marxismo e stalinismo, Arendt mostra que outros marxista defendiam um governo violento, para Mao Tsé-tung, por exemplo, o "'poder brota do cano de uma arma". A autora ressalta que nos escritos de Marx as irrupções violentas precediam, mas não causavam, o surgimento da nova sociedade. Além disso, o poder da classe dominante não se assentava na violência, mas em seu papel no processo de produção. Nesse sentido, esta defesa de um governo violento que realiza a revolução consistiria em uma distorção do pensamento marxiano. Conferir em Sobre a Violência, p. 26.

${ }^{97}$ Ver em Entre o Passado e o Futuro, p. 112.
} 
finalidade de fundar uma república. Esta tradição gerou o que a autora denomina de "revolucionários profissionais".

Segundo Arendt, o papel dos revolucionários profissionais, embora relevante historicamente falando, não consistiu em preparar as revoluções. Para ela, estes geralmente foram surpreendidos com a eclosão espontânea de um evento revolucionário, e, somente aí, saíram da biblioteca ou do café para as ruas, em direção à vida pública. Estes intelectuais, por se apresentarem como especialistas em situações revolucionárias, geralmente se oferecem para ocupar os cargos públicos e guiar a revolução e, com isso, influenciam bastante no curso dos acontecimentos.

"E como ele [o revolucionário profissional] fez seu aprendizado na escola das revoluções passadas, invariavelmente irá exercer essa influência não em favor do novo e do inesperado, e sim em favor de alguma ação que esteja de acordo com o passado" (Sobre a Revolução, p. 326).

Conforme a autora, isto ocorreu na Revolução Russa. Os teóricos da revolução refrearam a ação inesperada dos sovietes para direcionarem o percurso revolucionário. Eles tinham aprendido com o desenrolar da Revolução Francesa que, depois da emergência dos conselhos revolucionários e da derrubada do antigo regime, era preciso centralizar o poder e usar a violência para mudar radicalmente a estrutura social. De acordo com ela, no que concerne à influência da Revolução Francesa sobre a Russa, não foram as ações que romperam com o passado para constituir um novo corpo político baseado na liberdade que inspiraram os revolucionários profissionais russos, mas o curso histórico da Revolução Francesa.

Arendt ainda indica outras duas diferenças entre Marx e alguns marxistas que consistem precisamente naquilo que distancia o pensador do totalitarismo. A primeira consiste no fim da história e a segunda diz respeito à observação de padrões na história. Marx foi o primeiro e o maior dos historiadores a confundir padrão com sentido. ${ }^{98} \mathrm{O}$ autor identificou em todos os períodos históricos conflitos entre ricos e pobres, dominantes e dominados, além disso, observou que tais conflitos, por vezes, geravam mudanças na realidade. A partir disso, extraiu a fórmula da luta de classes como motor da história e predisse que o fim da história chegaria com a abolição das classes, o estabelecimento de uma sociedade igualitária. Para a autora, Marx, diferentemente de seus seguidores, sabia

\footnotetext{
${ }^{98}$ Conferir em Entre o Passado e o Futuro, p. 116.
} 
que se a história tem um sentido, então, terá um fim. Nessa perspectiva, ao apontar claramente o fim da história, o autor escapa do perigo que caíram seus sucessores de pensar a história como um movimento sem fim na qual cada fim atingido se transforma quase que imediatamente em meio para outro fim. ${ }^{99}$ Tal ideia de movimento sem fim, isto é, em que a finalidade do movimento histórico não é definida e estável, foi característico do totalitarismo: "[...] se é lei da história que, numa luta de classes, certas classes 'fenecem', a própria história humana chegaria ao fim se não se formassem novas classes que, por sua vez, pudessem 'fenecer' nas mãos dos governos totalitários" (Origens do Totalitarismo, p. 516). Este movimento histórico sem fim é claramente percebido na indicação incessante de inimigos do regime que nunca cessam de aparecer. No stalinismo, os primeiros perseguidos foram os opositores ao regime, depois os filhos dos antigos governantes, seguidos pelos russos de origem polonesa, logo após, os tártaros passaram a ser perseguidos e na sequência os antigos prisioneiros de guerra. ${ }^{100}$ Além disso, a linha partidária não tinha um objetivo claro e estabelecido, sempre variava de forma que o fim num dado momento se tornava meio.

Com relação aos padrões na história, Arendt nota que no século XX se descobriu que qualquer padrão pode parecer plausível, basta selecionar os momentos convenientes no passado. Nesse contexto, o estudo da história teve seu significado abalado uma vez que qualquer padrão e qualquer tendência histórica podiam ser encontrados.

"O padrão de Marx, pelo menos, baseava-se em um importante discernimento histórico: desde então temos visto os historiadores imporem ao labirinto de fatos passados praticamente qualquer padrão que lhes apraza, disso resultando que a ruína do fatual e do particular através da validade aparentemente maior de 'sentidos' gerais chegou mesmo a solapar a estrutura fatual básica de todo processo histórico, isto é, a cronologia" (Entre o Passado e o Futuro, p. 116).

Além da destruição da cronologia e do fatual particular, o surgimento dos movimentos totalitários demonstrou que qualquer hipótese pode se tornar fatual e concreta desde que as massas se mobilizem para produzi-la. "[...] o processo da ação, se for coerente, passará a criar um mundo no qual as hipóteses se tornam axiomáticas e autoevidentes" (Entre o Passado e o Futuro, p. 124). Por exemplo, Stalin afirmou, em 1930, que os dissidentes do partido consistiam em uma classe agonizante; pouco tempo mais

\footnotetext{
${ }^{99}$ Conferir em Entre o Passado e o Futuro, p. 114-115.

${ }^{100}$ Ver em Origens do Totalitarismo, p. 475.
} 
tarde, começou a eliminação física dos dissidentes. ${ }^{101}$ Dessa forma, a hipótese enunciada se tornou fatual assim que a perseguição dos dissidentes do partido fez deles uma classe agonizante. Na visão de Arendt, "o extermínio vira processo histórico no qual cada homem apenas faz ou sofre aquilo que, de acordo com as leis imutáveis, sucederia de qualquer modo" (Origens do Totalitarismo, p. 399). Aqui a autora chama a atenção para a distorção realizada pelos regimes totalitários na noção de lei e telos da filosofia da história.

A ideologia no totalitarismo, para a autora, consistiu em aplicar uma ideia à história, a qual passa a ser a "revelação de um processo que está em constante mudança", em que o curso dos acontecimentos se dá seguindo a coerência de um postulado lógico. ${ }^{102}$

De acordo com Arendt, os marxistas que usaram a concepção de tendência histórica sem indicar o fim da história acabaram por entender a revolução como algo permanente, uma vez que não foram capazes de estabelecer uma finalidade e um término para os eventos revolucionários. ${ }^{103}$ Além disso, aqueles que identificaram qualquer padrão histórico, além de carecerem de rigor teórico, ainda corriam o risco de transformar o marxismo em ideologia totalitária. ${ }^{104}$

Levando em conta as críticas de Arendt, é possível notar como os defensores da revolução entendida como mudança radical na esfera social, por vezes, acabaram por defender a centralização do poder para promover a igualdade e alguns chegaram a divulgar uma ideologia totalitária. Em ambos os casos, a Revolução Francesa era tida como modelo: no primeiro, o momento exemplar consistia na ascensão dos jacobinos ao poder; no segundo caso, o auge da revolução consistia no reinado do Terror.

Arendt aponta ainda outra interpretação da Revolução Francesa que apresenta o 18 Brumário de Napoleão Bonaparte como o apogeu da revolução. Esta interpretação, é claro, não é marxista, uma vez que, para Marx, a ditadura napoleônica consistiu no término da revolução, ou seja, no fim de seu potencial transformador em razão da promoção da classe burguesa. ${ }^{105}$ Ainda assim, a interpretação de que era napoleônica consistiu no verdadeiro

\footnotetext{
${ }^{101}$ Ver em Origens do Totalitarismo, p. 398.

${ }^{102}$ Conferir em Origens do Totalitarismo, p. 521.

${ }^{103}$ Ver em Sobre a Revolução, p. 82.

${ }^{104}$ É importante ressaltar que foi o marxismo, não o pensamento marxiano, que se tornou ideologia. Conferir em "Karl Marx and the Tradition of Western Political Thought", p. 277.

${ }^{105}$ Neste ponto Arendt concorda com Marx. Para ela, Napoleão Bonaparte foi aquele que pôs fim ao movimento revolucionário. De acordo com a autora, ele se manteve no poder por um longo período porque
} 
momento revolucionário se apoia em certa medida no procedimento de Marx de procurar na história uma tendência. Nesta intepretação, a história apontava para o progresso. Ora, se a história traz o progresso, a última etapa da revolução - a ascensão de Napoleão - seria a mais avançada.

\subsection{Conceito moderno de história e revolução: algumas conclusões.}

É importante destacar que, para Arendt, a inconsistência do pensamento liberal vem justamente da adoção da noção de progresso ao mesmo tempo em que recusa a história em termos hegelianos ou marxianos. ${ }^{106}$ Esta concepção de progresso, conforme a autora, está ligada ao conceito moderno de história que surgiu no mesmo período que a filosofia da história. Ambos mudaram a forma de tratar o passado. Para ela, tanto Hegel como os historiadores modernos entendem que a verdade reside no próprio processo temporal, isto é, o conhecimento surge do estudo da sequência temporal.

A concepção de história moderna tomou como modelo as ciências naturais, as quais utilizam a categoria de causa e efeito. Nesse contexto, os acontecimentos históricos recebem sentido ao serem inseridos em um encadeamento causal de fatos. De acordo com a autora, desde o século XVII, a preocupação da investigação científica está centrada no conceito de processo: "pensamos e consideramos tudo em termos de processos, não nos interessamos por entidades singulares ou ocorrências individuais e suas causas distintas e específicas" (Arendt, Entre o passado e o futuro, p. 93). Para a moderna maneira de pensar, nada é significativo em si ou por si mesmo. A noção de processo engolfa todas as coisas tangíveis e individuais. Por conseguinte, o processo adquire o monopólio da significação. ${ }^{107}$ No caso da história, o processo consiste na sequência temporal que confere o significado e o contexto.

governou em favor do interesse da sociedade de classe que emergiu depois da desestruturação dos antigos estamentos.

${ }^{106}$ Ver em Sobre a Violência, p. 41.

107 No ensaio "O conceito de história - antigo e moderno" (Entre o passado e o futuro), a autora rejeita a concepção de progresso histórico ao apontar os problemas da historiografia e da ciência modernas. Arendt mostra neste texto que a descoberta de que a Terra gira em torno do sol teria gerado uma mudança no modo pelo qual os homens buscam o conhecimento, pois a partir de então os sentidos e a experiência sensível ficariam sob suspeita, pois poderiam ser fonte de erros. Nesse contexto, não seria mais a contemplação o 
Para entender as causas e efeitos na história, o historiador procede como o cientista natural, procura acontecimentos que se repetem para estabelecer nexo causal entre os fatos. E a partir daí formulam leis universais. Nesta perspectiva, o historiador moderno, ao olhar para os eventos revolucionários na América e na França, procura a causa e o efeito da revolução: ambas foram causadas pelo abuso do governo monárquico, seu efeito inicial foram as guerras e, no longo prazo, o desenvolvimento da economia.

A concepção de que a história e também as revoluções indicam o progresso da humanidade, o qual pode ser notado no desenvolvimento econômico, está ancorada, em primeiro lugar, na filosofia da história, em segundo, na ligação entre história e modo de produção realizada por Marx, e, em terceiro lugar, nas teorias evolucionistas. Nas palavras da autora: “As palavras-chave da Historiografia Moderna - 'desenvolvimento' e 'progresso' - foram também, no século XIX, as palavras-chave dos novos ramos da Ciência Natural, em particular a Biologia e a Geologia [...]" (Entre o Passado e o Futuro, p. 93).

Arendt, evidentemente, discorda desta forma de tratar o passado. Para ela, o historiador deveria se ocupar de eventos singulares, que revelam uma paisagem única de ações e sofrimentos humanos. A tarefa de um historiador deve consistir em contar histórias sobre essas ações e sofrimentos, apontando seu significado, cada novo começo e as possibilidades perdidas. A novidade de um evento pode ser negligenciada se o historiador tenta explicá-lo pela concepção de causalidade. ${ }^{108}$ A causalidade é uma categoria das ciências naturais, lida com fatos recorrentes. Uma vez que não há novidade em processos naturais, este tipo de ciência enquadra tudo o que acontece em categorias pré-existentes. Quando a teoria da história importa a categoria de causalidade, reduz todos os assuntos políticos desconhecidos a fatos antigos e bem conhecidos. Foi o que aconteceu quando

meio de acesso à verdade, mas o experimento (uma pergunta formulada à natureza) passaria a ser considerado o meio apropriado para se atingir o saber. A ciência natural moderna parece mostrar que a experiência cotidiana, "[...] longe de ser capaz de constituir o modelo para a recepção da verdade e a aquisição de conhecimento, era uma constante fonte de erro e ilusão" (Entre o passado e o futuro, p. 85). Desde então, as ciências naturais encaram a observação como insuficiente e passam a se voltar mais para o experimento. A partir da teoria do heliocentrismo e da invenção do telescópio, a evidência dada pelos sentidos é posta em questão. Neste contexto, o que é considerado capaz de gerar conhecimento são a atividade dos processos mentais internos e a fabricação de instrumentos. Em outras palavras, somente pode ser conhecido aquilo que o homem produz. Nessa perspectiva, a ênfase não recai sobre as coisas, mas sobre o processo que as produz. Concomitantemente a esta mudança nas ciências que estudam a natureza, teria havido uma mudança no estudo da história. A história passaria a ser passível de ser conhecida como um processo conduzido pela humanidade.

${ }^{108}$ Conferir em Essays in Understanding, p. 318-319. 
alguns historiadores e teóricos descreveram as revoluções por meio das categorias antigas, como guerra, rebelião e golpe de Estado. Eles reduziram os novos eventos às categorias pré-concebidas. Além disso, as ações e decisões dos agentes perdem importância assim que os historiadores explicam um evento por meio de uma cadeia de causas.

De acordo com a autora, a concepção de história moderna, ao engendrar a noção de progresso, lança ao esquecimento todas as ações que apontariam para possibilidades que não se concretizaram. Ela conta a história da sociedade como se a vitória da ordem social vigente fosse inevitável. Ao traçar uma continuidade entre os acontecimentos por meio das categorias de causa e efeito, tudo o que é registrado tem uma consequência relevante, assim, o conceito de história moderno considera a vitória e a derrota como expressões do “julgamento objetivo" da própria história. Por isso, diversos intérpretes da Revolução Francesa negligenciaram as propostas de leis e instituições constituídas durante o período revolucionário republicano em prol do estudo do período napoleônico. Além disso, todas as experiências que duraram pouco tempo e foram raras são descartadas, uma vez que o historiador procura acontecimentos recorrentes. No caso da Revolução Francesa, a experiência nas comunas e assembleias primárias foi descartada por ter gerado um modo de ação breve e singular.

A dificuldade de lidar com os principais eventos do século XX, apontados no início de Sobre a Revolução, foi causada em parte pelo surgimento da filosofia da história e do conceito moderno de história, que mobiliza as categorias de causalidade e progresso.

De acordo com Arendt, a interpretação das revoluções realizada pela filosofia da história faz com que a liberdade perca espaço em prol da noção de necessidade. Esta interpretação suplanta a deliberação dos agentes ao explicar tudo por meio de uma tendência histórica, que faz parecer que os homens das revoluções foram levados por um movimento irresistível ou pela centralidade da questão social. Ao adotar o procedimento da filosofia da história, levar em conta a emergência da economia política e a valorização da fabricação e do trabalho na Modernidade, a conclusão lógica a que se chega é a de que as questões econômicas e sociais explicam a revolução.

Ainda, Arendt aponta que no século XX o procedimento da filosofia da história de Marx foi desviado quando alguns autores entenderam a história como um movimento sem fim. De acordo com ela, foi este desvio que deu abertura para o totalitarismo. 
Já a categoria de causa e efeito, importada das ciências naturais para a história, tenta conferir uma regularidade aos assuntos humanos que, de fato, não existe. Para encontrar repetições de acontecimentos e delas se extrair uma relação de causalidade, é preciso apagar as diferenças entre os fatos históricos e desprezar as singularidades. Somente ao se desconsiderar a especificidade dos eventos é possível explicar a vida política sempre com os mesmos conceitos. Isto ocorreu com os eventos revolucionários quando foram descritos como guerras, rebelião ou mudança de governo. Como já foi mencionado, tais conceitos não explicam a novidade e especificidade das revoluções. Arendt refuta aqui a noção de que os conceitos formulados no passado são aplicáveis a qualquer situação e afirma que os assuntos humanos são contingentes e abertos à novidade. Nesse sentido, o pensamento político deve considerar que um novo acontecimento requer um novo conceito e também que os conceitos políticos são dotados de historicidade, aceitam deslocamentos e novos usos.

Para Arendt, a noção de progresso histórico deveria ser fortemente questionada tendo em vista os fatos do século $\mathrm{XX}$. O desenvolvimento da ciência não foi apenas benéfico, vimos que o aumento do potencial letal das armas possibilitou massacres e assassinatos em massa e colocou em risco a existência da humanidade. Contudo, esta noção de progresso histórico ainda persiste.

O conceito moderno de história somado com a ruptura da tradição faz com que o passado seja considerado como um amontoado de destroços e ruínas. De um lado, a concepção de progresso afirma que não podemos aprender nada com os atos e feitos pretéritos, de outro, sem a tradição não há nada que indique o valor de pensamentos, obras e eventos do passado.

Para ilustrar isso, a autora retoma a nona tese do texto "Sobre o Conceito de História” de Benjamin.

"Há um quadro de Klee que se chama Angelus Novus. Representa um anjo que parece querer afastar-se de algo que ele encara fixamente. Seus olhos estão escancarados, sua boca dilatada, suas asas abertas. O anjo da história deve ter esse aspecto. Seu rosto está dirigido para o passado. Onde nós vemos uma cadeia de acontecimentos, ele vê uma catástrofe única, que acumula incansavelmente ruína sobre ruína e as dispersa a nossos pés. Ele gostaria de deter-se para acordar os mortos e juntar os fragmentos. Mas uma tempestade sopra do paraíso e prende-se em suas asas com tanta força que ele não pode mais fechá-las. Essa tempestade o impele irresistivelmente para o futuro, ao 
qual ele vira as costas enquanto o amontoado de ruínas cresce até o céu. Essa tempestade é o que chamamos de progresso" (Benjamin, Magia e Técnica, Arte e Política)

Na perspectiva arendtiana, esta passagem é a expressão de perplexidade gerada pela ruptura com a tradição e pela emergência do conceito moderno de história. Na imagem de Benjamin, a concepção de progresso aplicada à história é o vento que empurra o anjo para frente. $\mathrm{O}$ conceito moderno de história retira a possibilidade de que os grandes feitos, atos e pensamentos sirvam de exemplos ou de inspiração para os agentes no presente. Os acontecimentos, atos e concepções do passado podem ser desconsiderados se não forem a causa de um fato no presente; ou se forem entendidos como algo menos desenvolvido que apenas fez parte de uma etapa da evolução da humanidade; ou, ainda, se forem apenas um dos elementos que comprovam uma tendência da história. Nesse contexto, o anjo da história está com os olhos escancarados e boca aberta ao ver esta catástrofe: o desprezo pelas experiências, feitos e ideias antigas. ${ }^{109}$

Entretanto, a autora, ao tratar do pensamento de Benjamin, não menciona apenas o passado como ruínas, mas também como estoque de experiências onde se pode encontrar pérolas e corais. Por meio da citação e da linguagem é possível recuperar o passado. Importa lembrar que Arendt procura compreender os eventos ao questionar as categorias tradicionais, ao extrair dos pensadores do passado - como Aristóteles, Tucídides e Maquiavel - fragmentos de pensamento; e ao buscar a genealogia e historicidade dos conceitos. Dessa forma, a autora procura transformar o passado em estoque de experiências que são capazes de iluminar o presente.

A história do conceito de revolução é capaz de revelar tanto o significado político dos eventos revolucionários quanto os problemas para a sua compreensão. Ao construir a história do termo revolução, a autora indica como a reivindicação por um retorno aos velhos direitos conduziu os homens dos dois lados do Atlântico a romper com o passado e agir para constituir um novo corpo político. Além disso, ela mostra como as revoluções do século XVIII retomaram o antigo sentido de liberdade - que significava participar dos assuntos comuns - e o ampliaram na medida em que os revolucionários, mais do que tomar parte nos negócios públicos, estabeleceram novos espaços políticos e inauguraram uma

${ }^{109}$ Conferir Arendt em Homens em Tempos Sombrios, p.143. 
nova época. A história do conceito de revolução engendra ainda a interpretação dos eventos políticos no século XIX e XX, dessa forma, ela é capaz de revelar os problemas do pensamento político contemporâneo e o verdadeiro significado da noção de liberdade e fundação a partir da Modernidade. 


\section{Capítulo 2: As narrativas das Revoluções}

Vimos no capítulo anterior que, para Arendt, a narrativa histórica não deve ser elaborada por meio de uma lei ou finalidade histórica, nem deve ser formulada por meio da categoria de causa e efeito. Na perspectiva da autora, os eventos políticos, diferentemente dos fatos naturais, não são necessários, mas contingentes, na medida em que se relacionam com a liberdade e a ação de uma pluralidade de agentes. Somente quem olha retrospectivamente reconhece uma tendência. Já na perspectiva do agente, ou seja, do ponto de vista político, as possibilidades estão em aberto: diversos atores agem e manifestam intenções e opiniões plurais.

Para criticar o conceito moderno de história, Arendt recorre a forma antiga de compreender a história. De acordo com autora, para Heródoto, a tarefa do historiador era resguardar do esquecimento as palavras e feitos humanos. ${ }^{1}$ As grandes ações e discursos dos homens jamais sobreviveriam após sua realização sem o auxílio da recordação, ao contrário das coisas fabricadas pelos homens, que são bens duráveis, e das coisas da natureza, as quais perduram graças ao ciclo de reprodução. Ao apresentar Heródoto, a autora indica nas entrelinhas que a história deve se ater aos feitos humanos, não ao trabalho, ao desenvolvimento econômico ou ao modo de produção.

\footnotetext{
${ }^{1}$ Conferir em Entre o Passado e o Futuro, p. 73-74.
} 
Com base em Tucídides, ela trata da questão da objetividade e da imparcialidade como uma forma de abordar os eventos levando em conta mais de uma perspectiva. ${ }^{2}$ Os discursos relatados em História da guerra do Peloponeso demonstravam posições e interesses das partes em conflito e ainda apontavam para os momentos de escolha e deliberação. ${ }^{3}$ Segundo a autora, na perspectiva histórica dos gregos antigos, o central era narrar a ação dos homens, não um processo. Os rumos da história eram entendidos como fruto da deliberação, não como uma possibilidade única e necessária. ${ }^{4}$

Na perspectiva tucidideana, a história da Guerra do Peloponeso consistia no estudo do presente, na pesquisa dos fatos e no estabelecimento da relação entre eles, de modo a chegar à interpretação do que foi a guerra e o que ela significou para os homens que a viveram. Tucídides não reivindicou para sua obra a verdade sobre cada fato narrado ou discurso registrado, pois sabia das limitações da investigação histórica, mas reivindicou a verdade na compreensão geral da guerra. ${ }^{5}$

Inspirada na historiografia antiga, Arendt procura indicar qual foi o sentido da revolução para os homens que se engajaram na ação revolucionária no século XVIII. Especificamente, a autora tece sua narrativa sobre as Revoluções Americana e Francesa a partir da compreensão que os agentes que delas participaram tinham de seu tempo e os princípios que guiaram suas ações.

$\mathrm{Na}$ Antiguidade, a vitória e a derrota não eram as categorias centrais do julgamento histórico. Por exemplo, na narrativa tucidideana sobre a Guerra do Peloponeso, o mais importante não era a guerra em si, mas era registrar o modo de convivência na polis ateniense e espartana, tanto que o discurso fúnebre de Péricles ficou mais conhecido como

\footnotetext{
${ }^{2}$ Ver em Entre o Passado e o Futuro, p. 77-82.

${ }^{3}$ Conferir em Entre o Passado e o Futuro, p. 69-78.

${ }^{4}$ Apesar de Arendt e outros pensadores relacionarem Heródoto e Tucídides, os dois não tratavam a história da mesma forma. Tucídides foi o primeiro a rechaçar a maneira de investigação histórica de Heródoto: em primeiro lugar, por este explorar fatos abrangentes e não se restringir ao exame da vida política; em segundo lugar, pelo fato de Heródoto não deixar claro quais histórias e testemunhos ele considerava como verdadeiros. Nesse sentido, Tucídides acusou Heródoto de ser leviano por não se responsabilizar por tudo o que registrou. De acordo com Momigliano, no século XIX, os escritos de Tucídides e Heródoto voltaram a ser estudados. É curioso que naquele contexto eles não foram considerados historiadores com métodos distintos: admirava-se Tucídides pelas qualidades que se havia encontrado em Heródoto. Assim, os dois historiadores gregos foram entendidos na contemporaneidade como modelos complementares: a história da civilização complementava a história política e vice e versa. Ver em As raizes clássicas da historiografia moderna, p. 83.

${ }^{5}$ Ver, em História da guerra do Peloponeso, "O discurso dentro da obra tucidideana", comentário de Anna Lira de Almeida Prado.
} 
um elogio à democracia do que como um discurso de recrutamento para a guerra. Poderse-ia ainda somar outro exemplo: a narrativa de Salústio sobre a Guerra de Jugurta, tratou antes da corrupção em Roma do que das manobras militares e do exército vitorioso.

Arendt, ao tratar das revoluções, também não usa o critério de vitória ou derrota. A autora afirma que a Revolução Americana foi mais bem sucedida do que a Francesa por ter conseguido estabelecer uma constituição duradoura. No entanto, isso não significa que ela desvalorizou a experiência revolucionária francesa. Para Bignotto, esta comparação permitiu à autora pensar que o gosto pela liberdade deve se inscrever em instituições e regras dentro do espaço público. Nas palavras do autor:

'Nesse sentido, o 'fracasso' dos revolucionários franceses é mais importante do que o 'sucesso' dos americanos, uma vez que desvela o papel do texto constitucional na luta pela criação de uma forma de governo, que não podia recorrer a nenhuma forma estabilizadora proveniente de uma longa tradição." ("Hannah Arendt e a Revolução Francesa", p. 53).

Na narrativa de Arendt, a vitória e a derrota não são as categorias privilegiadas de análise, uma vez que a autora extrai lições sobre a política tanto de uma experiência bem sucedida como de um levante revolucionário que não conseguiu constituir um novo corpo político duradouro. Ela também trata das possibilidades perdidas - atos e princípios que foram esquecidos pela tradição revolucionária, mas de grande valor para a reflexão política. Para usar a metáfora da autora, em Sobre a Revolução ela procura identificar o tesouro perdido que não foi indicado por testamento algum.

Além de tratar do tesouro das revoluções que foi esquecido, a autora indica os problemas da fundação: aponta quais conceitos ajudaram a constituir um novo corpo político e quais colocaram em risco ou desvirtuaram o ato fundador. Nesse sentido, neste capítulo, em primeiro lugar, mostrar-se-ão as origens destes eventos revolucionários e aquilo que levou os homens da revolução a agir e, em segundo lugar, apresentar-se-ão os conceitos que influenciaram o decurso e o desfecho das Revoluções Americana e Francesa.

\subsection{Origens das revoluções: crise da autoridade, resistência e gosto pela liberdade}

No terceiro capítulo de Sobre a Revolução, intitulado "A busca da felicidade", Arendt procura as origens das revoluções. Para a autora, as revoluções são consequência da 
falta de autoridade política. Em outras palavras, um levante revolucionário só é possível onde a maioria não apoia o governo, onde o corpo político perdeu poder e autoridade. ${ }^{6}$ Segundo a autora, Montesquieu, quarenta anos antes da eclosão da primeira revolução moderna, já apontava para o enfraquecimento das bases que sustentavam os governos na Europa. De acordo com ele, os povos desconfiavam das leis e da autoridade, apenas os usos e costumes mantinham as pessoas unidas e regravam a convivência dentro das comunidades. $^{7}$ Desde o declínio do Império Romano até o século XVII, a teologia cristã era fonte para a explicação teórica da origem e extensão do poder político e da forma de governo. Com o enfraquecimento da tradição e da religião, a autoridade foi paulatinamente abalada.

No artigo "Que é autoridade?", a autora analisa mais detidamente a crise da autoridade na Modernidade. Em primeiro lugar, o conceito de autoridade é apresentado por meio da genealogia do termo e da distinção entre autoridade, poder e violência. Depois sua historicidade é apresentada. Nas palavras de Arendt: "Proponho a reconsiderar o que a autoridade foi historicamente e as fontes de sua força e significação" (Entre o Passado e o Futuro, p. 129).

$\mathrm{O}$ conceito e a palavra autoridade apareceram pela primeira vez em Roma: "A palavra auctoritas é derivada do verbo augere, 'aumentar', e aquilo que a autoridade ou os de posse dela constantemente aumentam é a fundação" (Arendt, Entre o Passado e o Futuro, p. 163). Nesse sentido, a autoridade política estava enraizada na grandeza dos feitos dos antepassados. Na perspectiva romana, agir sem os modelos e padrões consagrados pelo tempo e sem a sabedoria dos fundadores era inconcebível. Os senadores na República romana detinham autoridade na medida em que reclamavam ser os herdeiros dos fundadores, anciãos que conheciam os preceitos da vida política e, por este motivo, estavam aptos a aconselhar o povo. Conforme Arendt destaca, o papel do senado consistia em confirmar e acrescentar as ações do povo. A autora faz uma comparação entre a autoridade e os auspícios, os quais, diferentemente do oráculo grego (cuja função era

\footnotetext{
${ }^{6}$ Sobre a Revolução, p. 159.

${ }^{7}$ Sobre a Revolução, p. 160.
} 
mostrar o curso dos acontecimentos futuros), tinham o papel de aprovar ou desaprovar as decisões feitas pelos homens. ${ }^{8}$

De acordo com Arendt, embora a autoridade política tenha surgido em Roma, um dos aspectos deste conceito é de origem platônica. Basicamente, a autora encontrou em $A s$ Leis uma tentativa de introduzir na polis grega algo parecido com a autoridade: o ordenamento deveria ser obedecido, mas sem o uso da violência ou da persuasão. $\mathrm{Na}$ interpretação arendtiana de Platão, no governo do rei filósofo, as leis seriam baseadas nas ideias claras e eternas e, por se tratarem de verdades auto-evidentes, seriam reconhecidas pela mente dos homens. A coerção aqui é realizada pela Razão, não pelo uso da força. No entanto, o pensador grego conclui que a maioria dos cidadãos não se submete à verdade, pois não a conhece. Com relação a este problema, segundo a autora, ele encontra duas soluções: em A República, cria o mito do inferno para fazer obedecer aqueles que não se submetem à verdade; já em As Leis, ele afirma que o propósito do ordenamento deve ser explicado aos cidadãos. ${ }^{9}$ Neste caso, o conhecimento infundiria confiança nas leis.

Levando isso em conta, a autora afirma que a autoridade está baseada em uma hierarquia que é reconhecida como legítima por muitos e, por isso, dispensa o uso da força e da argumentação. Por buscar a obediência, ou melhor, o acolhimento de conselhos e preceitos, a autoridade geralmente é confundida com poder ou violência. No entanto, a autoridade é diferente de força ou dominação: onde a violência é usada, ela está ausente. Ela também se distingue do poder, que requer igualdade e envolve a persuasão: quando há debate, a autoridade é suspensa. "Se a autoridade deve ser definida de alguma forma, deve sê-lo, então, tanto em contraposição à coerção pela força como à persuasão através de argumentos" (Entre o Passado e o Futuro, p. 129). Dessa forma, a autoridade implica em uma espécie de obediência na qual os homens retêm a sua liberdade. ${ }^{10}$

\footnotetext{
${ }^{8}$ Para ilustrar melhor o papel do senado e o efeito da autoridade no corpo político, Arendt traz a imagem da embarcação: enquanto o poder está naqueles que a dirigem, a autoridade seria como seu mastro que mantém o barco em equilíbrio. Ver em Entre o Passado e o Futuro, p. 165.

${ }^{9}$ Ver em Entre o Passado e o Futuro, p. 147-149.

${ }^{10}$ Ao tratar de autoridade e política, Arendt não faz apologia a um governo autoritário ou ao autoritarismo. Para ela, os defensores destes tipos de governo entendem a autoridade como violência. Conferir em Entre o Passado e o Futuro, p. 133-135.
} 
Para Arendt, a tradição está ligada à autoridade na medida em que ela era o fio que guiava o olhar para o passado, que selecionava os grandes acontecimentos que deveriam ser lembrados e os grandes exemplos que deveriam ser emulados.

"Nesse contexto basicamente político é que o passado era santificado através da tradição. A tradição preservava o passado legando de uma geração a outra o testemunho dos antepassados que inicialmente presenciaram e criaram a sagrada fundação e, depois, a engrandeceram por sua autoridade no transcurso dos séculos. Enquanto essa tradição fosse ininterrupta, a autoridade estaria intata [...]" (Entre o Passado e o Futuro, p. 166).

Nesse sentido, sem tradição ninguém pode se tornar herdeiro de grandes homens e ninguém pode aconselhar com base na experiência dos antepassados. Por se referir ao passado e à fundação da cidade, a autoridade era o elemento de estabilidade e durabilidade do mundo. ${ }^{11}$

Com o declínio do Império Romano, a autoridade foi da esfera política para a religiosa. De acordo com Arendt, a Igreja Católica adotou o pensamento romano e fez da morte e ressurreição de Cristo uma nova fundação. Os apóstolos, por serem testemunhas da vida, da morte e da ressurreição de Cristo, tornaram-se pais fundadores da Igreja. Eles legaram seu testemunho através de gerações e gerações. A autoridade religiosa, portanto, foi transmitida de Cristo para os apóstolos e dos apóstolos para o clero.

Além da experiência de fundação romana, o aspecto platônico da autoridade foi adotado pela Igreja: de um lado, as leis são consideradas eternas e verdadeiras uma vez que foram feitas por Deus. A autoridade religiosa também se assenta no reconhecimento de que seus preceitos devem ser seguidos em virtude de sua característica divina. ${ }^{12}$ De outro lado, o medo do inferno fortaleceu a obediência à doutrina católica. ${ }^{13}$

Dessa forma, a Igreja, nesse contexto de desestruturação do poder da cidade de Roma, tornou-se responsável pelo poder secular: da Idade Média até o absolutismo, a autoridade do governante vinha de Deus e a comprovação desta autoridade era a coroação feita pelo Papa e o apoio do clero ao monarca. Nas palavras da autora: “Assim é que, ao término do século V, o Papa Gelásio I pôde escrever ao Imperador Anastácio I: 'Duas são

\footnotetext{
${ }^{11}$ Conferir em Entre o Passado e o Futuro, p. 131.

${ }^{12}$ Ver em Entre o Passado e o Futuro, p. 170.

${ }^{13}$ Conferir em Entre o Passado e o Futuro, p. 175-177.
} 
as coisas pelas quais esse mundo é principalmente governado: a autoridade sagrada dos Papas e o poder real"' (Entre o Passado e o Futuro, p. 169). ${ }^{14}$

Já na Modernidade, com a secularização e a Reforma, por um lado, a Igreja perdeu influência política e, por outro, a vida pública perdeu a autoridade, isto é, a sanção religiosa, a legitimidade divina. Isso gerou instabilidade nas formas de governo na Europa.

Assim, a perda da autoridade era um problema geral no século XVIII. Nesse contexto surge uma questão: se Arendt vincula a ausência de autoridade com revolução, por que ocorreram levantes revolucionários somente na América do Norte e na França? A resposta é simples, para a autora, não foi apenas este elemento que fez surgir eventos revolucionários. Dito de outra forma, a crise da autoridade por si mesma não conduz automaticamente à revolução. Em suas palavras:

"Mesmo onde há uma visível perda de autoridade, as revoluções só podem surgir e vencer quando existe um número suficiente de homens preparados para esta derrocada e, ao mesmo tempo, dispostos a assumir o poder, a se organizar e agir junto com vistas a uma finalidade comum" (Sobre a Revolução, p. 159).

Segundo a autora, o que levou os homens a agir e levar a cabo as revoluções foi o gosto pela liberdade pública [freedom]. Como foi visto no capítulo anterior, o conceito de liberdade surgiu na polis grega e significava participar dos assuntos públicos, isto é, ter o direito de falar e ouvir, de ver e ser visto. Ser livre significava conviver entre concidadãos sem governar [rule] nem ser governado [ruled]. "Pois a liberdade política, em termos gerais, significa o direito de 'ser participante do governo' - afora isso, não é nada" (Arendt, Sobre a Revolução, p. 278). Nessa perspectiva, os homens que se engajaram na ação revolucionária desenvolveram um gosto pelo debate público e um gosto pela participação nos assuntos comuns. Para a autora, a disposição para a ação surgiu do apreço pela liberdade pública.

No caso dos norte-americanos, embora fossem governados pela coroa inglesa, eles já tinham experimentado a felicidade pública, isto é, o gosto de decidir sobre a organização da vida da comunidade por meio de pactos, corporações e assembleias municipais. Os colonos cuidavam da convivência nos assuntos em que a coroa não regulava. Em outras palavras, naquilo em que o domínio metropolitano silenciava, os colonos debatiam e

\footnotetext{
${ }^{14}$ A Igreja também ficou responsável pela tradição, de certa forma guiava as ações e costumes por meio de seu código moral e também resguardava o conhecimento por meio de suas bibliotecas e escolas.
} 
deliberavam. Ao contrário, no caso francês, o gosto pela liberdade pública surgiu da leitura sobre a política. O absolutismo não deixava espaço para o debate dos assuntos comuns. Nesse contexto, os franceses não podiam participar das decisões e da organização da vida em comunidade nem sequer como espectadores. Este afastamento da atividade política e a invisibilidade dos assuntos públicos fizeram com que a política pudesse ser tratada apenas teoricamente, isto é, por meio da leitura das narrativas sobre as experiências políticas antigas e da discussão acerca destas leituras. Arendt denomina "homens de letras" os franceses que se dedicaram ao pensamento e à discussão da ação política. Nas palavras da autora:

"Existiam homens no Velho Mundo que sonhavam com a liberdade pública [public freedom], existiam homens no Novo Mundo que provaram a felicidade pública - são estes, em última análise, os fatos que determinaram que o movimento de restauração, de recuperação dos antigos direitos e liberdades [liberties], evoluísse para uma revolução dos dois lados do Atlântico" (Arendt, Sobre a Revolução, p. 188).

Nesse sentido, para Arendt, de um lado do Atlântico, foi a experiência dos colonos na vida pública e, do outro lado, foi o estudo dos homens de letras que promoveram o gosto pela liberdade e impulsionaram as revoluções.

"A liberdade pública e a felicidade pública foram os princípios inspiradores que prepararam o espírito daqueles que, então, fizeram o que jamais tinham esperado fazer, e na maioria das vezes foram levados a ações pelas quais não sentiam nenhuma inclinação prévia" (Arendt, Sobre a Revolução, p. 168).

$\mathrm{Na}$ perspectiva da autora, as revoluções foram algo inédito e não planejado. As reclamações específicas que os colonos tinham contra os abusos do governo metropolitano e as críticas dos franceses aos desmandos do monarca absolutista, graças ao gosto pela liberdade pública, tornaram-se, paulatinamente, uma contestação do regime monárquico que culminou na defesa da república. A monarquia passou a ser entendida como tirania por deter o monopólio do direito de agir e promover o banimento parcial ou total do povo da esfera pública. É importante notar que os homens das revoluções romperam com a concepção tradicional de monarquia e tirania ao identificarem uma com a outra e ao afirmarem que o governo de um só era degenerado porque destituía os demais da cidadania. $^{15}$

\footnotetext{
${ }^{15}$ Sobre a Revolução, p. 175
} 
Em resumo, no capítulo "A busca da felicidade", Arendt compreende que os eventos revolucionários surgem graças ao gosto pela liberdade, o qual prepara o espírito dos homens para agir no mundo quando o corpo político perde autoridade e o regime está em franca desintegração. No caso norte-americano, a reclamação contra a alta dos impostos, a denúncia do absurdo de haver uma "taxação sem representação" e a reivindicação dos mesmos direitos dos ingleses levaram os colonos a fundar um novo corpo político com base na liberdade: eles, durante a revolução, decidiram agir para ampliar sua experiência de autogoverno e estabelecer um corpo político e autoridade próprios. Nessa perspectiva, a entrada dos colonos no mundo público não foi uma novidade: eles já haviam se dedicado à atividade política. A novidade na Revolução Americana foi a experiência da ação fundadora, em outras palavras, os colonos passaram de homens de ação para revolucionários no momento em que constituíram um novo sistema de poder.

Arendt, no artigo "Desobediência Civil", afirma que a divergência [dissent] e a resistência [resistance] são fenômenos que estão na origem da República norte-americana. Para ela, o povo se organizava em associações voluntárias, como nomeou Tocqueville, para consentir ou divergir acerca de questões importantes para a comunidade. Tais associações consistiam em organizações $a d$ hoc que perseguiam um objetivo comum que, quando atingido, tinha como efeito o desaparecimento da associação. ${ }^{16}$

De fato, para Tocqueville, a América do Norte foi o lugar em que a ação por associação foi mais usada. Ali, os indivíduos se associavam para resolver problemas cotidianos de várias ordens: comercial, industrial, moral, religioso e também político. Em outras palavras, eles conjugavam esforços com seus semelhantes para agir no mundo. ${ }^{17}$

A liberdade de associação, de acordo com o autor, é uma garantia contra a tirania da maioria, pois torna pública a opinião de uma minoria. Na América do Norte, os cidadãos associavam-se para, em primeiro lugar, contar o número que constituía a minoria e, em segundo lugar, procuravam os argumentos propícios para persuadir a maioria a se juntar à causa. ${ }^{18}$ Nessa medida, as associações procuravam debater e persuadir, não

\footnotetext{
${ }^{16}$ Conferir em Crises da República, p. 84-85.

${ }^{17}$ Conferir em Tocqueville, A Democracia na América, p. 219 e 220.

${ }^{18}$ Ver em A Democracia na América, p. 225.
} 
combater, coagir ou usar violência contra a maioria. Segundo Tocqueville, "O direito de associação é uma importação inglesa e existiu desde sempre na América" ( $A$ Democracia na América, p. 223). Por isso, os homens do Novo Mundo eram experientes na liberdade, sabiam moderar as palavras e manter o objetivo da associação, não buscavam representar a maioria ou combatê-la, nem tentavam substituir os poderes Legislativo e Executivo, antes, visavam a persuadir a maioria e peticionar ao governo.

De acordo com Arendt, a contestação ou divergência surge quando um grupo de pessoas desafia abertamente uma lei ou decisão do governo a fim de manter um estado de coisas ou mudar algo no mundo. Os contestadores, normalmente, são uma minoria organizada que se levanta contra um suposto consenso da maioria silenciosa, contra uma maioria que se encontra inarticulada. As minorias, no momento em que expressam publicamente sua divergência, podem incitar uma mudança no ânimo e na opinião da maioria e assim tornar sua reivindicação mais poderosa. ${ }^{19}$

Arendt indica que a desobediência civil acontece, geralmente, em um contexto em que os canais normais destinados a acolher queixas não funcionam mais ou que as queixas não são mais consideradas. ${ }^{20} \mathrm{~A}$ contestação pode se tornar resistência quando as instituições e autoridades se mostram incapazes de tratar as questões políticas adequadamente e seguem sem considerar as manifestações públicas de parte da comunidade. Foi o que ocorreu na América do Norte antes da revolução.

Starling também trata da ligação entre associativismo e a Revolução Norte Americana. Para ela, associar-se significava, no contexto revolucionário do Novo Mundo, agir politicamente: era o modo pelo qual os homens poderiam debater, instruírem-se, deliberar, preparar discursos e também o modo de mudar o mundo público. ${ }^{21}$

Em 1764, a promulgação da nova lei de arrecadação na colônia gerou contestação de alguns grupos espalhados em diferentes regiões. ${ }^{22}$ Nos anos seguintes, a Coroa inglesa

\footnotetext{
${ }^{19}$ Ver em Crises da República, p. 87.

${ }^{20}$ Ver em Crises da República, p. 58.

${ }^{21}$ Ver em "A Matriz Norte-Americana", p.248.

${ }^{22}$ Heloísa Starling afirma que a Lei do Açúcar "[...] atualizava os direitos da Coroa sobre o melaço e o açúcar refinado e impunha novas taxas sobre o vinho, a seda, o índigo, o café e os produtos têxteis de origem não britânica" ("A Matriz Norte-Americana", p. 233). Um ano mais tarde, em 1765, a Coroa promulgou a Lei do Selo, que impunha taxas em diversos impressos que circulavam pela colônia, tais como jornais, reclames, almanaques; regulava tarifa de apólices de seguros, documentos de embarque, entre outros. Conferir em "A Matriz Norte-Americana", p. 235.
} 
seguiu impondo leis para aumentar a arrecadação de imposto e intensificou a centralização das decisões. Nesse contexto opressivo, o mote dos contestadores "nenhuma taxação sem representação" promoveu o debate sobre representação e acabou por atingir a maioria dos colonos. Isto abalou gradativamente a legitimidade do Parlamento inglês na América do Norte. ${ }^{23}$ Além disso, a opinião compartilhada na colônia de que nenhuma lei poderia entrar em vigor sem o consentimento das assembleias do povo evoluiu para a identificação entre liberdade e participação no governo e, por fim, impulsionou a bandeira do autogoverno.

Em resumo, o ato de contestação das novas taxas impostas a partir de 1764 se transformou em resistência quando a Coroa inglesa se mostrou indiferente às queixas dos colonos. Segundo Starling:

"As ações de resistência coordenada pelas associações se multiplicaram em toda a área colonial norte-americana entre 1765 e 1776 e incluíram boicotes e greves de natureza claramente política, como o dos portuários de Nova York contra a descarga de navios ingleses, em 1768, e os trabalhadores de Boston contra a construção de fortificações britânicas na cidade" ("A Matriz Norte-Americana", p. 244).

Pouco a pouco, a resistência, isto é, o questionamento da autoridade e do poder das instituições inglesas, conduziu os homens do Novo Mundo à fundação de um novo corpo político que garantisse a liberdade de participar nas decisões dos assuntos da comunidade.

Arendt ressalta que a inclinação para a resistência contra a opressão já estava inscrita nos pactos [compact] e promessas que os primeiros colonos estabeleceram ao chegarem na América do Norte. Como as leis metropolitanas que regulavam as colônias eram omissas em certos aspectos e não havia regras e costumes pré-estabelecidos no Novo Mundo, era preciso estabelecer limites e princípios compartilhados para refrear os excessos e a iniquidade de que os homens são capazes. Segundo a autora, os colonos se associaram por meio de obrigações mútuas para evitar abusos e arbitrariedades entre os membros da nova comunidade que se formava. ${ }^{24}$ Em suas palavras: "Promessa é o modo exclusivamente humano de ordenar o futuro, tornando-o previsível e seguro até onde seja humanamente possível" (Crises da República, p. 82).

Este tipo de promessa tem característica semelhante à teoria do contrato de Locke. Em contraste com a aliança [covenant] bíblica e com o pacto exposto por Hobbes, o

\footnotetext{
${ }^{23}$ Conferir no artigo de Starling “A Matriz Norte-Americana”, p. 234-235.

${ }^{24}$ Conferir em Sobre a Revolução, p. 225-227.
} 
contrato [contract] lockeano é horizontal. O primeiro tipo de pacto, estabelecido entre Deus e um povo, é vertical na medida em que estabelece a obediência incontestável dos mandamentos divinos. No segundo, todos os indivíduos transferem seu poder para uma autoridade secular em nome da segurança e com isso se produz uma hierarquia entre os súditos e o governante. Já no terceiro tipo de pacto, os indivíduos membros estabelecem primeiro uma comunidade por meio de uma promessa mútua e depois constituem um governo. Dessa forma, o governo pode ser dissolvido uma vez que não está acima da comunidade civil. ${ }^{25}$

Nesse sentido, o direito de resistência ao abuso de poder está inscrito neste tipo de pacto. Para Arendt, os pactos entre os habitantes da colônia foram a base para a fundação da República norte-americana por dois motivos, a saber, a comunidade foi constituída muito antes de um governo próprio e os pais fundadores, notadamente John Adams, apoiaram-se em parte no pensamento de Locke. ${ }^{26}$ Levanto isso em conta, a autora conclui que o espírito das leis na América do Norte consiste no consentimento e no direito de divergir.

Além disso, a autora sugere que a contestação de leis e de decisões do governo deve existir em todo corpo político que não seja autoritário ou tirânico em virtude da natureza da política. A mudança é inerente aos assuntos humanos na medida em que o mundo é renovado potencialmente pelo nascimento de novos seres humanos. Cada novo agente adentra o mundo como um estrangeiro recém chegado e lida com coisas e relações que foram estabelecidas previamente. Nesse contexto, os recém chegados podem manter um estado de coisas por meio do consentimento ou procurar renovar o mundo por meio da contestação e da ação. ${ }^{27}$

No caso dos homens da Revolução Norte-Americana, eles começaram por contestar as novas regras de taxação impostas pela Coroa inglesa e, por meio do debate em associações voluntárias e dos corpos civis já constituídos, perceberam que seu direito de consentir e divergir seria mais bem assegurado com a fundação de um novo corpo político.

\footnotetext{
${ }^{25}$ Ver em Crises da República, p. 77-78.

${ }^{26}$ É importante sublinhar que Arendt, em "Desobediência Civil", cita Locke em segunda mão, por meio dos textos de John Adams.

${ }^{27}$ Conferir em Crises da República, p. 70.
} 
Do ponto de vista da experiência no espaço público, a novidade na Revolução Francesa foi muito maior. Os franceses, ao contrário dos norte-americanos, não tinham participação na vida pública. Seu conhecimento sobre política se limitava à leitura de tratados políticos e de histórias sobre os feitos dos antigos. Os franceses estavam impedidos de agir porque a monarquia absolutista obstruía amplamente o espaço público. Os homens da Revolução Americana, para debater e agir, recorreram aos corpos públicos organizados durante o período colonial. Os franceses não puderam contar com órgãos públicos pré-existentes: não se convocavam os Estados Gerais e assembleias primárias há 200 anos. $^{28}$

Nesse contexto, os homens de letras tiveram um papel central na revolução: cultivaram e disseminaram o gosto pela liberdade pública. Por meio da escrita, eles prepararam o espírito dos franceses para agir. Starling, ao analisar a circulação e o efeito de panfletos nas duas revoluções do século XVIII, mostra que na França os panfletos tinham conteúdo de fácil compreensão popular e contava com riqueza de formas: diálogos, poemas, cartas, entre outros. A grande circulação destes panfletos teve como efeito a deslegitimação do Antigo Regime. Já na América do Norte, os panfletos não eram escritos por homens de letras e, por isso, não portavam grande valor literário. A circulação destes panfletos visava a articular o ativismo dos colonos, seu efeito foi denunciar a investida da Coroa inglesa contra a liberdade e debater a criação de novas leis e instituições políticas. ${ }^{29}$

Levando isso em conta, a mudança na experiência dos homens na França de 1789 foi muito mais drástica: eles eram homens privados - trabalhavam, fabricavam e, com relação à atividade política, apenas escreviam, liam e pensavam - e, do dia para a noite, tornaram-se mais do que homens públicos, transformaram-se em revolucionários.

Tanto os revolucionários do Velho quanto do Novo Mundo se apoiaram nos pensamentos e feitos antigos quando se engajaram na revolução. Eles enfrentavam uma autoridade política em crise: tanto o governo metropolitano inglês quanto a monarquia francesa não eram mais entendidos como legítimos. Estes regimes perderam o suporte da sanção religiosa e da tradição na medida em que o processo de secularização e algumas

\footnotetext{
${ }^{28}$ Ver em Kalyvas, Democracy and the Politics of the Extraordinary, p. 228.

${ }^{29}$ Sobre os panfletos na Revolução Francesa, conferir em "A Matriz Norte-Americana”, p. 252; já sobre os panfletos na Revolução Americana, ver na p. 255.
} 
mudanças na forma de governar os distanciavam dos antigos costumes e direitos. ${ }^{30}$ Nesse contexto, as experiências antigas se mostraram valiosas para os homens preocupados com as questões públicas. ${ }^{31}$ Uma vez que o conceito e a experiência de autoridade política têm origem romana, a leitura sobre este período poderia lançar luz sobre o problema com o qual os homens se deparavam. A partir do estudo e da discussão sobre a fundação de Roma, tanto os revolucionários franceses quanto os norte-americanos chegaram à conclusão de que somente com a fundação de um novo corpo político eles poderiam resolver a crise de autoridade. Além da relação entre autoridade e fundação, a experiência antiga indicava a ligação entre fundação e liberdade pública. Nesse sentido, é possível afirmar que o apreço pela liberdade pública e pela ação em detrimento dos conceitos de liberdade veiculados pela tradição filosófica - isto é, o livre arbítrio e a vontade - tenha surgido da preocupação com a crise da autoridade.

De acordo com a autora, os franceses, ao elegerem os antigos como companhia, descobriram o verdadeiro significado de liberdade: a liberdade está ligada ao livre pensamento e à espontaneidade, mas não se encerra no interior do sujeito, pois significa agir e falar numa esfera pública.

Para entender melhor o modo pelo qual os homens na França se engajaram na ação é preciso aqui abordar a ligação entre a faculdade do juízo e revolução a fím de esclarecer sobre o gosto pela liberdade pública e a escolha dos antigos como exemplo. Esta conexão entre a faculdade de julgar e a revolução, que construiremos neste trabalho, é um pouco problemática na medida em que ela é apontada em Sobre a Revolução, mas não é desenvolvida neste livro e nem em outros escritos, quando a autora, anos mais tarde, debruça-se sobre a questão do juízo e a conecta mais com a moral do que com a política. Por exemplo, em Responsabilidade e Julgamento, Arendt sublinha que a conduta moral tem como principal preocupação o eu, ao contrário, na ação política o que está em foco é o mundo, não o eu ou uma pessoa. ${ }^{32}$ Nesse sentido, a autora não esclareceu suficientemente a

\footnotetext{
${ }^{30}$ Conferir em Sobre a Revolução, p. 160-161.

${ }^{31}$ Ver em Sobre a Revolução, p. 165, 168 e 169.

${ }^{32}$ Ver em Responsabilidade e Julgamento, p. 113 e 143. A autora acrescenta em Crises da República que o cidadão se preocupa com as consequências que o erro terá no mundo, já o sujeito moral se preocupa com as consequências do erro para sua consciência. Conferir em Crises da República, p. 57.
} 
mediação entre a faculdade de julgar e a ação. ${ }^{33}$ Abaixo relacionaremos revolução e juízo a partir de indícios encontrados no texto da autora sem desconsiderar que há lacunas e dificuldades nesta exposição.

Entendemos que, ao declarar o gosto pela liberdade pública, os homens de letras cortejaram a aprovação dos demais, isto é, almejaram que tal juízo fosse aprovado por outras pessoas que, então, passariam a compartilhar o apreço pela liberdade pública. Tocqueville, no livro III de sua obra $O$ Antigo Regime e a Revolução, já havia identificado que a revolução se tornou inevitável quando surgiu e foi divulgado o gosto pela liberdade. De acordo com este autor, os homens de letras se tornaram, no século XVIII, os principais políticos na França. Embora eles fossem inexperientes no governo, sua ocupação era discutir e publicizar os problemas políticos.

Em Lições sobre a filosofia política de Kant, Arendt mostra como o julgar, uma faculdade do espírito, pode se ligar ao mundo. Para ela, a concepção kantiana de juízo do gosto tem relação com a vida política na medida em que sua questão chave é a sociabilidade. Esta capacidade do espírito humano, a fim de se desenvolver, depende da convivência entre os homens. ${ }^{34}$

Nessa perspectiva, é possível superar as particularidades dos sentidos, as diferenças de gostos. Em alguns assuntos é possível superar condições subjetivas e criar uma intersubjetividade. Embora a experiência do gosto seja algo particular, ela pode ser comunicada e avaliada. ${ }^{35}$

Antes de comunicar o que julgamos, devemos levar em consideração os outros. Para tanto, a imaginação primeiro transforma uma percepção sensível imediata em objeto para o juízo e, depois, representa a opinião e o gosto dos outros dentro do espírito. A operação da imaginação, ao formar uma representação da percepção sensível, distancia o

\footnotetext{
${ }^{33}$ As dúvidas sobre a interligação e a passagem do juízo para a ação se devem, por um lado, ao fato de a autora ter se deparado com questão do julgar quando tratou da conduta de Eichmann e do colapso moral observado na Alemanha nazista e, por outro lado, ao fato de a terceira parte do livro $A$ vida do Espírito dedicada ao julgar - não ter sido escrita.

${ }^{34}$ Conforme Arendt, dois tipos de particulares são tratados na Crítica do Juizo, a saber, o belo e a natureza. Ora, o belo existe somente em sociedade, é algo publicamente reconhecido: mesmo que alguém não goste de uma obra de arte, reconhece-a como tal graças à comunidade em que está inserido.

${ }^{35}$ Enquanto a percepção dos sentidos indica o que agrada ou desagrada, o juízo aprova ou desaprova a sensação provocada. Arendt traz o exemplo do ódio, sentimento que pode agradar alguns, mas não é aprovado pelo juízo, pois não é considerado bom pela sociedade. Nesse sentido, pode-se aprovar ou desaprovar aquilo que agradou ou desagradou.
} 
espírito do objeto ou fenômeno e das sensações causadas por ele. Isso torna possível construir um juízo, ou seja, apreciar as qualidades do fenômeno (belo, feio, certo, errado etc). Em outras palavras, a imaginação pode transformar uma sensação, o gostar ou o desagradar, em objeto de reflexão. É justamente isto que torna possível a comunicação, pois não é possível transmitir aos outros uma sensação, mas se pode comunicar a apreciação e a representação que a reflexão constrói.

Além disso, a imaginação permite a representação de opiniões e gostos possíveis de outras pessoas, ela pode representar um debate público dentro da mente. Importa ressaltar que esta faculdade não é capaz de fornecer os pontos de vistas reais de outros homens, estes podem ser obtidos apenas pela conversação com amigos ou pelo debate numa arena pública. Arendt, em "Algumas questões sobre fillosofia moral”, esclarece esta afirmação por meio da seguinte ilustração:

“[...] vamos supor que eu veja uma moradia específica na favela e perceba nessa construção particular a noção geral que ela não exibe diretamente, a noção de pobreza e miséria. Chego a essa noção ao representar para mim mesmo como me sentiria se tivesse de viver ali, isto é, tento pensar no lugar do morador da favela. O julgamento a que vou chegar não será necessariamente igual a dos habitantes, a quem o tempo e a falta de esperança podem ter embotado qualquer sensibilidade à afronta de sua condição, mas vai se tornar um exemplo marcante para os meus julgamentos posteriores destas questões" (Responsabilidade $e$ Julgamento, p. 206).

O imaginar forja no espírito de cada homem particular a ideia de humanidade, isto é, reproduz a presença dos outros, da comunidade. Nessa perspectiva, a operação de julgar lida com particulares, pluralidade e generalidade, ou seja, percepções de objetos ou fenômenos particulares que se tornam gerais e plurais na operação de levar em conta outros pontos de vista.

No contexto revolucionário, os homens de letras, antes de comunicar seu apreço pela liberdade pública, consideraram que outras pessoas, as quais estavam excluídas da vida política, também gostariam de debater sobre os assuntos comuns.

Ainda, os homens de letras, ao tornarem público seu apreço pela liberdade em sentido político, declaravam também que preferiam esta concepção à de livre-arbítrio. Na perspectiva arendtiana, o julgar é justamente a faculdade encarregada pela escolha dentre coisas, atos e pensamentos. No artigo "A Crise na Cultura: Sua Importância Social e Política", a autora discute a relação entre escolha e cultivo do gosto. Para ela, a cultura 
animi de Cícero significa cultivar o espírito, no sentido de aprimorar a sensibilidade à beleza, desenvolver o gosto. Para isso, é preciso antes conhecer as grandes obras, pensamentos e atos dos mortos e dos vivos e depois escolher com que pessoas e coisas do passado e do presente se quer conviver. ${ }^{36}$

No início de Dos Deveres, por exemplo, Cícero estabelece relação entre aprender e julgar ao afirmar que se deve aplicar o juízo na leitura da filosofia e das letras gregas. ${ }^{37} \mathrm{O}$ autor procura nesta obra retirar dos escritos dos estoicos, acadêmicos e peripatéticos aquilo que era mais adequado e conveniente para tratar do tema dos deveres. Em suas palavras: "Eu devo, portanto, neste momento e nesta questão seguir sobretudo os estoicos, não como um expositor, mas, conforme meu costume, extrair de suas fontes quando e quanto parecer melhor, usando meu próprio juízo e discernimento". 38

Esta concepção de cultura animi, num primeiro olhar, parece ser possível somente aos sábios, uma vez que exige conhecimento, parece ser um atributo daqueles que se dedicam ao estudo e à contemplação. No entanto, ao tratar de Eichmann, Arendt indica que este conhecimento se trata de algo muito mais simples. A autora sublinha que Eichmann entrou para o partido Nacional Socialista e para a SS sem saber do que se tratava, "jamais conheceu o programa do Partido, nunca leu Mein Kampf' (Eichmann em Jerusalém, p. 45). De acordo com a autora, ele era um adesionista e se juntava a qualquer grupo sem procurar saber minimamente as ideias e atividades do mesmo. Ele simplesmente não se importava com a questão de escolher uma boa companhia, qualquer coisa lhe era satisfatória. Pode-se inferir desta passagem que Arendt não exige um saber profundo para que a faculdade de julgar opere, mas apenas indica que, para escolher bem com quem se quer conviver e a que grupo pertencer, é preciso informar-se um pouco e se dedicar ao cultivo do gosto, isto é, exercer a faculdade de julgar, algo de que Eichmann abriu mão.

Nessa perspectiva, para desenvolver o gosto, julgar e escolher, é preciso conhecer aquilo que se pretende avaliar. No caso dos homens de letras na França, antes de

\footnotetext{
${ }^{36}$ Sobre Cícero e cultura animi, conferir em Entre o Passado e o Futuro, p. 266-268 e 278-281.

37 Conferir em On Duties, Livro I, parágrafo 2.

38 "I shall, therefore, for the present and on this question, follow the Stoics above all, not as an expositor, but, as my custom, drawing from their fountains when and as it seems best, using my own judgment and discretion”. Em On Duties, livro I, parágrafo 6.
} 
escolherem a liberdade no sentido político em detrimento da liberdade filosófica, eles se informaram sobre seu significado por meio dos escritos dos antigos.

De acordo com Arendt, uma escolha não envolve somente o sujeito que julga, mas outras pessoas e o mundo. Quando escolhemos conviver com uma coisa, pensamento ou ato, nós preservamos e cuidamos disso, resguardamos sua existência no mundo. Além disso, a expressão do gosto e do juízo acerca de um fato, obra ou pensamento revela mais do que aquilo que foi objeto de avaliação, revela também qualidades pessoais daquele que expressou seu juízo. Dito de outra forma, ao comunicar seu juízo, o indivíduo revela mais do que a coisa que foi avaliada, também revela algo de si mesmo.

Dessa forma, na medida em que o sujeito comunica seu juízo acerca de um objeto do mundo, os outros podem avaliar não só o juízo expressado, mas também a qualidade pessoal que foi revelada. Comunicar um juízo abre a possibilidade dos outros se relacionarem com o objeto avaliado e com o sujeito que expressou o juízo, isto significa que os demais podem se aproximar ou se afastar daquele que comunicou seu juízo, compartilhá-lo ou comunicar um juízo diferente.

Arendt deixa isto claro no final do artigo "Algumas questões sobre filosofia moral" quando especula sobre a possibilidade de alguém, ao invés de escolher algo bom, escolher a companhia de uma figura cruel como o Barba Azul. Neste caso, ela indica que os demais podem desaprovar tal escolha e aqueles que a desaprovam se afastariam desta pessoa, pois sua escolha revelou qualidades pessoais más, como a crueldade. Este afastamento gerado pela expressão do gosto é politicamente relevante para a autora se levarmos em conta seu conceito de poder. Para ela, o poder é gerado com a ação em concerto e com o apoio da opinião. O isolamento, nesta perspectiva, tem como efeito a impotência. Neste caso, se aquele que revela que prefere o Barba Azul como companhia não tiver apoio, ele não poderá realizar nada no mundo.

Segundo Arendt, a validade dos juízos é diferente da validade das proposições científicas. As ciências possuem uma validade universal, as evidências compelem todos por meio da razão a admitir sua verdade. Já os juízos do gosto não podem ser comprovados, eles devem ser compartilhados, devem cortejar o acordo dos demais, persuadir apelando para o senso de comunidade, não para um procedimento de dedução ou 
inferência. ${ }^{39} \mathrm{Na}$ interpretação da autora, quando Cícero diz "Perante os céus, prefiro extraviar-me com Platão do que ter concepções verdadeiras com seus oponentes", ele avalia Platão por meio do juízo, não por meio da razão, pois descarta o critério de verdade e afirma a grandeza de Platão como filósofo exemplar. ${ }^{40}$

Com isso a autora mostra que as faculdades humanas operam de formas distintas: a cognição busca o conhecimento para estabelecer a verdade, elabora esquemas e ideias; já o juízo conhece para escolher dentre coisas, atos e pensamentos. Para ilustrar isso, a autora trata da mesa como um esquema e da mesa como um exemplo. Para definir um esquema de mesa ou uma mesa em abstrato, a cognição representa diversas mesas particulares para extrair delas as qualidades mínimas comuns a todas. Já o juízo representa diversas mesas para escolher a melhor entre elas, e esta será tida como a mesa exemplar. ${ }^{41}$

Nessa perspectiva, julgar significa tomar uma posição frente a um fenômeno ou objeto particular. Esta é a diferença do juízo reflexionante com relação às proposições cognitivas: aquele não busca uma adequação do particular à regra geral, mas tem que construir a regra a partir do fenômeno ou objeto. O juízo reflexionante estético de Kant indicou para Arendt um modo de reflexão que leva em consideração a particularidade do objeto e a pluralidade do mundo. Para a autora, assim como no julgar estético, o juízo político deve refletir sobre a singularidade dos fenômenos no mundo e ainda levar em conta os outros para validar-se publicamente.

"Cultura e política, nesse caso, pertencem à mesma categoria, porque não é o conhecimento ou a verdade que está em jogo, mas sim o julgamento e a decisão, a judiciosa troca de opiniões sobre a esfera da vida pública e do mundo comum e a decisão quanto ao modo de ação a adotar nele além do modo como deverá parecer doravante e que espécie de coisas nele hão de surgir" (Entre o passado e o futuro, p. 277).

Arendt, ao tratar da faculdade de julgar e da escolha da companhia e de exemplos de grandes atos, pensamentos e coisas, indica como os homens escolhem agir. Para ela, os exemplos são uma espécie de corrimão para o juízo, apoiam a reflexão e podem guiar a ação. ${ }^{42}$ Nesse sentido, quando os homens de letras comunicaram seu gosto pela liberdade

\footnotetext{
${ }^{39}$ Conferir em $A$ vida do espírito, p. 378.

${ }^{40}$ Ver em Entre o Passado e o Futuro, p. 279.

${ }^{41}$ Ver em Responsabilidade e Julgamento, p. 210.

${ }^{42}$ Conferir em Responsabilidade e Julgamento, p. 209.
} 
pública e outros aprovaram e compartilharam este gosto, um grande número de homens se tornou inclinado a refletir e agir em nome da liberdade em sentido político.

Mais uma vez, a interpretação arendtiana é apoiada pelo estudo de Tocqueville. Para o autor, a noção de liberdade política, às vésperas da revolução, não estava só na cabeça dos escritores, mas era também assunto cotidiano da multidão. Em suas palavras: "A ideia de que o povo inteiro tem o direito de participar do governo penetra nos espíritos e apodera-se deles" (Tocqueville, O Antigo Regime e a Revolução, p. 150). Além disso, na interpretação de Arendt, ao escolherem como exemplo e companhia os antigos que se dedicaram aos assuntos públicos, os homens de letras se predispuseram a agir.

É importante esclarecer que os homens de letras não eram intelectuais. Os intelectuais são, segundo a autora, especialistas que contribuem com as burocracias governamentais. Eles, por se considerarem detentores do conhecimento científico, não se engajam no debate público e no processo de persuasão, uma vez que consideram que a validade de suas proposições são universais: as evidências provariam sua verdade. Esta definição arendtiana de intelectuais parece se aproximar mais da descrição de Tocqueville acerca dos fisiocratas. As ideias destes, de acordo com este autor, eram mais afeitas à liberdade de empreendimento do que à liberdade política: eles não defendiam a participação popular no governo, ao contrário, propunham que as reformas necessárias para o desenvolvimento deveriam ser realizadas por especialistas. Na perspectiva dos fisiocratas, a figura do Estado deve suplantar a do governante: as instituições administrativas devem ser deixadas a salvo da interferência das discussões públicas. Dito de outra forma, o Estado deveria funcionar mecanicamente seguindo regras préestabelecidas de funcionamento, e não ser guiado pelo debate ou deliberação. ${ }^{43}$ Já os homens de letras entendiam que suas ideias e proposições tinham relação com a vida em comunidade e por isso deveriam ser compartilhadas. Para tanto, eles buscavam persuadir seus leitores, almejavam que suas opiniões fossem apoiadas pelos demais. De maneira alguma pensavam que tratavam de verdades absolutas que deveria compelir a todos. ${ }^{44}$

\footnotetext{
${ }^{43}$ Ver em O Antigo Regime e a Revolução, p. 147-148.

44 De acordo com a autora, os homens de letras recusavam os trabalhos burocráticos e se distanciavam do social, esfera que mistura questões privadas e públicas (ver em Sobre a Revolução, p. 166-167).
} 
Ainda é preciso distinguir os homens de letras dos revolucionários profissionais, estes sim uma espécie de intelectuais. O papel deste tipo específico de intelectual, historicamente falando, não consistiu em preparar as revoluções, mas em dirigi-las depois de sua eclosão. Na perspectiva teórica, o revolucionário profissional não interpreta as revoluções como eventos, mas como consequência de uma necessidade histórica, e por isso entende que todas as revoluções devem seguir um determinado curso. ${ }^{45}$ Já os homens engajados na ação no início das Revoluções Americana e Francesa entendiam que o passado lançava luz aos problemas do presente, mas não indicavam uma trajetória única a ser seguida.

Se entendermos os homens de letras como pessoas de espírito cultivado, então, podemos afirmar que eles se preocupavam com o mundo. Nesse sentido, eles teriam percebido que o espaço público estava em risco: a política se tornara invisível com o absolutismo. Com o exemplo dos antigos, os homens de letras teriam aprendido que a política é o espaço de visibilidade e que seria preciso agir para salva-la. Nesta perspectiva, os franceses, ao se dedicarem à leitura, não se tornaram apenas eruditos, mas homens cultos que sabiam valorizar o espaço público e a convivência com seus concidadãos. Eles teriam sido impelidos para a ação ao debaterem sobre a crise política de seu tempo e ao elegerem emular o modo de ação dos antigos.

A autora indica que mesmo quando o espaço público é restrito e os homens perdem a possibilidade de serem livres por meio da ação, ainda é possível ligar-se ao mundo. Para ela, quando o espaço público se torna obscuro, os homens procuram o único tipo de liberdade que pode ser experimentado, o livre pensamento. Lessing é o exemplo de alguém que viveu em um tempo sombrio, privado do espaço público, e que, embora tenha se dedicado ao pensar, não se encerrou em seu próprio eu, antes, procurou fazer dentro de si um diálogo antecipado com os outros. Ao exprimir seu pensamento por meio da escrita na tentativa de começar um diálogo entre pensadores, o autor tentou abrir um espaço mundano entre ele e seus leitores. ${ }^{46}$ É evidente que este diálogo de pensadores não substitui a ação, mas cultiva o apreço pelo mundo e a relação com os outros mesmo em tempos sombrios.

\footnotetext{
${ }^{45}$ Sobre revolucionário profissional conferir em Sobre a Revolução, p. 325 e 326.

${ }^{46}$ Ver em Homens em tempos sombrios, p. 19.
} 
Levando isso em conta, é plausível uma aproximação entre os homens de letras e esta atitude de Lessing. Os homens de letras, ao publicarem seus escritos sobre liberdade e política, abriram um espaço mundano, que foi o ponto de partida para a abertura de um espaço público político. Em outras palavras, norte-americanos e, principalmente, os franceses, a partir da discussão sobre instituições políticas, direitos e cidadania, fizeram surgir um espaço de debate que inspirou a ação e acabou por instaurar um espaço público onde eles podiam agir.

Vemos que na Revolução Francesa, como não havia espaço público previamente organizado onde o povo poderia se manifestar, a escrita teve um papel considerável: não somente na divulgação da noção de liberdade pública, mas na convocação dos Estados Gerais, ocasião em que, além de votar, o povo também escreveu suas queixas com relação à condução dos negócios públicos. ${ }^{47}$ Nesse contexto, as opiniões daqueles que não faziam parte da nobreza ou do clero puderam circular por meio da escrita.

É importante sublinhar que a escolha de pensar sobre o mundo e cuidar dele não leva necessariamente à ação. Preservar os monumentos do passado, escolher a companhia entre homens, coisas e pensamentos, pensar o mundo e abrir um espaço mundano de conversa entre pensadores não é o mesmo que agir. Tudo isso pode possibilitar a ação: um autor, quando trata das crises e problemas sofridos numa comunidade, pode abrir um espaço de debate público. Mais que isso, um autor, ao anunciar um princípio de ação, pode dar início a um empreendimento em concerto.

Na perspectiva arendtiana, a ação é uma possibilidade sempre que os homens escolhem cuidar do mundo. No entanto, a escolha de cuidar do mundo não funda necessariamente um espaço público e condições para agir. Isto porque a ação é livre, não é causada por uma cadeia de acontecimentos precedentes e seu desenrolar não é determinado por regras históricas ou naturais. ${ }^{48}$

Nesse sentido, identificamos em Arendt mais de um caminho para a ação nos eventos revolucionários. Alguns revolucionários do Novo Mundo já participavam das assembleias municipais e assuntos comuns; outros revolucionários, em ambos os lados do Atlântico, eram homens de letras que cultivaram seus espíritos e buscaram na Antiguidade

\footnotetext{
${ }^{47}$ Conferir em Michelet, História da Revolução Francesa, p. 91.

${ }^{48}$ Ver em $A$ Vida do Espírito, p. 343.
} 
referências para enfrentar a crise de seu tempo, e, da mesma forma que Lessing, assumiram um compromisso com o mundo e buscaram pensar e dialogar sobre ele.

Importa acrescentar que a narrativa arendtiana que explica como os homens se engajaram nas revoluções atesta que há mais de uma forma de agir e de constituir o espaço público, o engajamento na vida política não tem uma via única. Nessa perspectiva, a ação é ligada à pluralidade em dois aspectos, a saber, envolve um conjunto de pessoas singulares e não tem uma única forma de ser realizada.

Resumidamente, na teoria da autora, a ação é caracterizada pelo espaço em que é realizada, pelas suas pré-condições e forma. Especificamente, seu lugar é uma cena pública. Suas condições são a pluralidade, a libertação - estar livre das necessidades da vida e do domínio de outrem - e a igualdade - ter o direto de ver e ser visto, de falar e ser ouvido. Sua forma é o ato ou performance acompanhada do discurso. De maneira esquemática, a ação se divide em duas partes: o início e seu desenrolar. E é realizada por agentes distintos: o líder, que põe algo em movimento, e o público, que sustenta e dá continuidade ao ato inicial. ${ }^{49}$

Como já foi mencionado no capítulo anterior, para ilustrar a ação, no artigo "Que é liberdade?", Arendt faz uma analogia com o teatro: o agente, assim como o ator, realiza uma performance diante de um público e busca conquistar a benevolência da audiência por meio do virtuosismo. O agente deve representar suas opiniões e esclarecer o princípio de seu ato de maneira excelente para persuadir os demais a apoiarem-no. ${ }^{50}$ Assim, o que está em jogo na ação são os princípios e juízos compartilhados. Ao contrário, as qualidades naturais e privadas do agente, suas motivações e vontades, não contam em uma cena pública.

Por envolver uma pluralidade de agentes, a ação não pode ser realizada em razão de uma motivação ou vontade individual, ela só pode ser movida por um princípio que transcenda a subjetividade de cada um e que possa ser compartilhado pelos agentes. Nas palavras da autora:

"Distintamente de sua meta, o princípio de uma ação pode sempre ser repetido mais uma vez, sendo inexaurível, e, diferentemente de seu motivo, a validade de

\footnotetext{
${ }^{49}$ Conferir em Entre o Passado e o Futuro, p.214.

${ }^{50}$ Conferir em Entre o Passado e o Futuro, p. 200.
} 
um princípio é universal, não se ligando a nenhuma pessoa ou grupo em especial" (Arendt, Entre o Passado e o Futuro, p. 199).

Levando em conta que no pensamento arendtiano princípios inspiram a ação, é importante identificar qual princípio foi capaz de mover os homens a agir. De acordo com Arendt, o gosto pela liberdade e a felicidade de participar dos assuntos políticos levaram os homens nos dois lados do Atlântico à revolução. Embora a autora não relacione agir e julgar de forma explícita, a partir da discussão acima, pode-se inferir que, frente à situação de crise de autoridade, os homens das revoluções buscaram compreender seu tempo e agir no mundo. Essa compreensão, além de indicar os problemas políticos que deveriam ser enfrentados, elege o princípio de ação que os homens deveriam adotar. Assim, as ideias e concepções dos homens da revolução indicam o sentido de sua ação e auxiliam a autora a desvelar o significado da revolução. Esta é a razão pela qual a autora discute as ideias enunciadas pelos principais líderes das Revoluções Americana e Francesa, para compreender o curso e o desfecho destes eventos. A seguir trataremos das concepções políticas centrais veiculadas pelos revolucionários no Novo e no Velho Mundo.

Mas antes de apresentar a narrativa arendtiana sobre as duas revoluções do século XVIII, retomaremos brevemente as reflexões acerca de discurso, ação e história apresentada em A Condição Humana. A autora afirma neste livro que todo ato é acompanhado de um discurso, o qual desempenha duas funções, a saber, revelar quem é o agente e anunciar o que ele faz e pretende fazer. As estórias que resguardam os grandes feitos políticos parecem se fiar no discurso uma vez que tratam do sentido da ação e desvelam quem é o agente, isto é, sua a singularidade e essência.

Para Arendt, o agente não consiste no autor das estórias: ao agir ninguém pode antever com certeza todas as consequências de seus atos e nem de calcular até quando o ato será levado a cabo. A ação se dá na teia de relações humanas e por isso conta com inúmeras vontades e intenções conflitantes. Por esta razão, dificilmente o objetivo que estava na mente do iniciador é atingido. $\mathrm{O}$ ato do iniciador, ao incidir na teia de relações humanas, provoca reações, que são mais do que meras respostas ao ato inicial, são ao mesmo tempo novos atos. Dito de forma diferente, cada ato é circundado por outros atos e 
discursos. ${ }^{51}$ Dessa forma, o iniciador não tem controle sobre a ação que iniciou, não sabe qual o fim, o término nem quantas pessoas se envolvem ou se envolverão com ela.

Levando isso em conta, Arendt afirma que o sentido da ação só pode ser alcançado quando ela acaba, só se revela para o contador de estórias que olha para o passado e narra seu início, seu desenrolar e seu fim. Tais estórias são para a autora a condição para que haja a história, que consiste em um conjunto das estórias da humanidade. ${ }^{52}$

Em Sobre a Revolução, Arendt parece estar preocupada primordialmente com a ação e a enunciação de seu princípio de forma que a questão de expressar quem foram os revolucionários é secundária. Em sua narração sobre o curso da ação revolucionária, os atores identificados são apenas os líderes e iniciadores, isto é, aqueles que enunciaram princípios que foram compartilhados e conduzidos pelos demais. Em outras palavras, a narrativa foca nas concepções dos revolucionários mais eminentes e explica as formas pelas quais elas foram levadas adiante.

A revelação de quem foram os revolucionários parece ter menos relevância por dois motivos: primeiro, é impossível apontar todos os envolvidos na ação em virtude da pluralidade dos agentes engajados nas revoluções. Dessa forma, apenas a estória de alguns pode ser contada. Em segundo lugar, a revelação de "quem alguém é" parece ser mais importante para os atores do que para o contador de estórias. De acordo com Arendt, um dos impulsos que leva alguém a agir é o espírito agonístico, o desejo de revelar-se e distinguir-se dos outros. ${ }^{53}$

A revelação da essência e da singularidade dos principais revolucionários na França e na América do Norte é um efeito lateral da narrativa arendtiana. Como veremos a seguir, a autora, para compreender o sentido da ação revolucionária no Velho e no Novo Mundo, procura identificar os princípios de ação enunciados e indicar quais foram esquecidos e quais foram levados adiante.

\footnotetext{
${ }^{51}$ Ver em A Condição Humana, p. 232.

${ }^{52} \mathrm{Em}$ A Condição Humana, p. 231.

53 Outro impulso para agir está relacionado com o nascimento. A inserção no mundo é como um segundo nascimento. Cada um, ao escolher viver em companhia de outros no espaço público, reafirma seu nascimento em dois sentidos: confirma sua existência singular com os outros ao aparecer publicamente e reafirma a novidade advinda com o nascimento ao colocar em movimento algo que nunca antes existiu. Conferir em $A$ Condição Humana, p. 221.
} 


\subsection{Os Pais Fundadores}

Com relação às figuras eminentes da Revolução Americana, Arendt destaca Madison e Jefferson. As ideias do federalista basicamente são mobilizadas para explicar as novidades surgidas na constituição, enquanto que as ideias de Jefferson indicam principalmente as falhas desta revolução.

Para a autora, o principal problema enfrentado pelos Pais Fundadores era como estabelecer uma república em um grande território. Como já foi mencionado, a monarquia era identificada à tirania e a forma de governo republicana era entendida como adequada à liberdade. Durante a revolução, a experiência de debate público e a ação em concerto nas assembleias municipais fizeram os colonos formular uma nova concepção de liberdade e de poder, que não se restringia ao livre-arbítrio ou às liberdades civis e não tinha conexão com domínio ou monopólio da força. Nas palavras de John Jay, os homens, depois de se engajarem na luta contra a opressão da Coroa Inglesa, experimentaram os encantos da liberdade e entenderam que não bastava a libertação da tirania; o que faria os homens realmente livres seria a participação nos assuntos públicos. ${ }^{54}$

Segundo Arendt, quando os colonos entenderam que o poder surge da ação de muitos em conjunto e não significa obediência ou emprego dos meios de violência, tomaram a consciência de que deveriam fundar um novo corpo político, sem precedentes na história. Só assim poderiam desfrutar da liberdade e decidir em conjunto os rumos de suas vidas no Novo Mundo.

Para ela, os federalistas buscaram na experiência política colonial e na prudência dos antepassados as concepções para fundamentar e apoiar a constituição desta nova república. O desafio inovador nesse contexto não consistia na declaração de direitos, uma vez que a experiência de governo limitado não era novidade, mas consistia em criar um novo sistema de poder, bem dividido e equilibrado. Para tanto, estes homens relacionaram o pensamento de Montesquieu e concepções da República romana com suas experiências políticas.

\footnotetext{
${ }^{54}$ Ver em Sobre a Revolução, p. 62.
} 
Nos artigos 47 e 48 de $O$ Federalista, Madison define a tirania como o regime em que uma pessoa ou um grupo acumula os poderes Executivo, Legislativo e Judiciário. Em sua concepção, uma república bem estabelecida deve separar e conter estes três ramos do poder dentro de limites fixados. Nesse contexto, Montesquieu é retomado para indicar em que sentido os poderes devem ser distintos: separá-los não significa desconectá-los completamente, antes, significa fixar o papel de cada um e entrelaçá-los de forma que um possa exercer controle constitucional sobre outro. Além disso, no artigo 51, o autor se ocupa de tratar de medidas que impeçam que um poder se torne mais forte que os outros ou que um venha a ser dependente de outro. As eleições frequentes, por exemplo, devem fazer com que os membros do Executivo e do Legislativo sejam dependentes do povo e não uns dos outros. Ainda, os mandatos curtos limitam a extensão e duração destes poderes. Já os cargos do Judiciário são vitalícios para impedir que os juízes se tornem dependentes da autoridade que os nomeou.

Conforme a autora, Madison pensava que não se podia confiar aos homens um poder ilimitado e, por isso, além de estabelecer direitos, era preciso constituir um sistema de poderes que pudesse proteger a sociedade contra a opressão do governante e evitar que uma parte da sociedade fosse injusta com a outra. Nessa perspectiva, era preciso estabelecer um sistema de poderes balanceado para que nem uma minoria dominasse a maioria e nem a maioria aniquilasse as minorias. Em outras palavras, o objetivo era constituir procedimentos de decisão da maioria e garantir que tais procedimentos não permitissem a sua tirania. ${ }^{55}$

Para defender a constituição de uma república em território extenso, Madison e Hamilton se apoiaram no princípio federativo e na definição de poder de Montesquieu, que, relacionados, possibilitavam pensar na combinação de poderes e na associação de pequenas repúblicas. ${ }^{56} \mathrm{Na}$ interpretação de Arendt, para Madison, o pensador francês esclarece que a lei apenas limita o poder, mas não é capaz de refreá-lo. Somente um centro de poder tem a capacidade de refrear outro centro sem tirar sua potência. Nesse sentido, esta concepção de poder auxilia no desenho de um corpo político com centros de poder associados, isto é, paralelos, mas não excludentes. Para Arendt, a proposta federalista da

\footnotetext{
${ }^{55}$ Conferir em Sobre a Revolução, p. 202.

${ }^{56}$ Ver em Sobre a Revolução, p. 203.
} 
proporção e equilíbrio entre os entes estaduais e a União se apoia nesta definição de poder e no princípio federativo.

A concepção de lei e autoridade romana também auxiliaram Madison e os fundadores a pensar nas instituições do novo corpo político norte-americano. Segundo Arendt, existem basicamente três concepções de lei: a grega, a hebraica e a romana. $\mathrm{Na}$ concepção grega, a lei é um ato pré-político que estabelece o âmbito público e suas regras. Este ato é comparado com a construção do muro em torno da cidade, o qual estabelece e delimita o espaço comum. A figura do legislador é central nesta concepção de lei. Diferentemente, a lei hebraica consiste nos Mandamentos de Deus, nesta perspectiva, a vontade divina é a fonte de todas as leis. Já os romanos concebem a lei como um vínculo e conexão entre diferentes grupos dentro de uma comunidade política. ${ }^{57}$

Arendt afirma que uma Constituição ${ }^{58}$ baseada na concepção de lei romana é duradoura e estável porque considera a comunidade política como plural: associa as pessoas e grupos distintos de tal forma que eles são capazes de participar nos assuntos públicos, sem que os conflitos e dissensos levem as instituições à ruína. Para a autora, a lei em Roma, desde o início da cidade, tinha o papel de vincular os homens. Por exemplo, foi por meio de um tratado que os romanos se associaram aos sabinos, por meio da lei, os patrícios se relacionavam com os plebeus. Desse modo, o corpo político, apesar dos conflitos internos e das guerras, foi capaz de se manter por muito tempo. Vale ressaltar que a concepção hebraica de lei não podia mais estabelecer uma Constituição estável e duradoura depois da secularização. Desde que os governos perderam a sanção religiosa, a lei entendida como um mandamento se transformou na expressão da vontade do governante. O problema consiste em que, ao contrário da vontade divina, que é eterna e estável, a vontade humana é inconstante e instável. Nesse sentido, a nova Carta Constitucional na América retomava a concepção de lei romana na medida em que visava a fundamentar e pautar as relações entre os grupos e pessoas, Estados e União na nova república.

\footnotetext{
${ }^{57}$ Conferir em Sobre a Revolução, p. 241-245.

${ }^{58}$ Veremos no próximo capítulo deste trabalho que o termo constituição possui dois significados: um se refere ao documento que registra leis, ou seja, a uma Carta Constitucional, e o outro diz respeito ao ato de um povo que estabelece leis e instituições.
} 
Como foi mencionado acima, a autoridade para os romanos estava ligada ao ato fundador, ela indicava a prudência dos antepassados, daqueles que constituíram Roma ou aumentaram sua grandeza. A autoridade, nesse sentido, significava aumentar e sustentar a fundação. ${ }^{59}$ Segundo Arendt, a partir destas concepções, os homens da revolução norteamericana entenderam que a Carta Constitucional seria dotada de autoridade por ser fruto da fundação e seguir os princípios anunciados na Declaração de Independência. Além disso, a Constituição seria aprovada e sustentada, pois seus princípios surgiram dos debates nos municípios e Estados. Nesse sentido, este documento consistiria na fonte da lei por ser fundamento da relação entre as pessoas, grupos e entes federativos.

Para a autora, duas instituições novas surgiram a partir destas ideias e experiências dos revolucionários, a saber, a Suprema Corte e o Senado. A Suprema Corte foi a instituição projetada para resguardar a Constituição e, consequentemente, é a instância dotada de autoridade. A permanência dos juízes em seu cargo e a ausência de rotatividade são a indicação do assento da autoridade: o conhecimento dos juízes com relação às leis e à Constituição é reconhecido de forma que eles podem indicar as interpretações possíveis das leis e aconselhar os agentes sobre as regras constitucionais. Dessa forma, este consiste no ramo de poder menos assertivo. A Suprema Corte é responsável por conferir equilíbrio ao corpo político na medida em que evita que ou uma minoria ou uma maioria se imponham de forma tirânica. ${ }^{60}$

Já o Senado era reservado ao debate público, à representação de opiniões. Segundo Arendt, Madison concebia o povo como uma pluralidade de pessoas que possuem uma diversidade de opiniões. Para ele, onde quer que houvesse liberdade de expressão haveria também opiniões diferentes. ${ }^{61}$ Por isso, seria prudente criar uma instituição onde as diversas opiniões pudessem ser representadas, trocadas e refinadas. A autora ressalta que o Senado não equivale à Câmara dos Lordes inglesa, cuja função era oferecer espaço para a formulação e defesa dos interesses da aristocracia hereditária. ${ }^{62} \mathrm{O}$ Senado era uma nova instituição que tinha o papel de proteger a república da tirania da opinião unânime e

\footnotetext{
${ }^{59}$ Ver em Entre o Passado e o Futuro, p. 163.

${ }^{60}$ De acordo com Kalyvas, a Suprema Corte tem autoridade na medida em que interpreta e resguarda a Carta Constitucional. O Senado romano, de forma distinta, tinha autoridade, pois reencarnava os fundadores da cidade [paters]. Conferir em Democracy and the Politics of Extraordinary, p. 279.

${ }^{61}$ Ver em Sobre a Revolução, p. 133.

${ }^{62}$ Conferir em Sobre a Revolução, p. 287.
} 
possibilitar a liberdade de opinião e expressão. A opinião pública, devido à sua unanimidade, provoca uma oposição também unânime, esta polarização empobrece o debate público uma vez que as distinções e nuances das opiniões são perdidos. Por isso, os pais fundadores desenharam uma instituição para resguardar a diversidade de opiniões. Embora carregue o mesmo nome que a instituição romana, trata-se de instituições distintas: o Senado romano resguardava a autoridade, sua função era aconselhar, não era representar as diversas opiniões que surgiam na comunidade. ${ }^{63}$

Neste momento é importante sublinhar uma diferença entre a concepção de Arendt e Madison. Embora ambos concordem em que uma república livre conta com pluralidade de opiniões, para a autora, o debate público em si depura as diversas opiniões formando um senso compartilhado, enquanto que, para Madison, as variadas opiniões populares são alargadas e filtradas em razão da sabedoria e virtude dos senadores. Em outras palavras, Arendt indica que a troca de opiniões é capaz de esclarecer aqueles que participam do debate e buscam a sabedoria. Isto é capaz de gerar um princípio comum ou interesse que leva em consideração diversos pontos de vista. Em suas palavras, "[...] nenhum indivíduo sozinho - nem o sábio dos filósofos, nem a razão divinamente informada do iluminismo, comum a todos os homens - jamais está à altura da tarefa de peneirar opiniões [...]”. Já Madison afirma que os representantes são cidadãos proeminentes capazes de discernir os verdadeiros interesses comuns dos temporários ou parciais. Em sua perspectiva, a opinião dos representantes pode vir a condizer mais com o bem público do que a opinião do povo. ${ }^{64}$

Em Sobre a Revolução não fica claro o motivo pelo qual a pensadora não critica esta concepção elitista de república apresentada por este federalista. Tal concepção legitima de certa forma a divisão entre governantes e governados e contribui para a restrição do espaço público.

Para Arendt, duas categorias importantes para a atividade política que tinham sido negligenciadas pela tradição foram valorizadas na Revolução Americana com a criação do

\footnotetext{
${ }^{63}$ Ver em Sobre a Revolução, p. 257. Starling também trata das concepções de Madison. Para ela, este federalista temia a forma clássica da democracia, que poderia levar a tumultos ou à tirania da maioria. Por isso, ele defendeu o sistema de representação, para garantir a expressão da pluralidade de opiniões, que impede a tirania e para filtrar e decantar as opiniões populares. Conferir em "A Matriz Norte-Americana", p. 295.

${ }^{64}$ Ver em $O$ Federalista, artigo 10, p. 152.
} 
Senado e da Suprema Corte: a opinião e o julgamento. ${ }^{65}$ Estas duas instituições dizem respeito à conservação da república. O Judiciário salvaguarda a Constituição e o Senado assegura a representação de opinião de diversos grupos para evitar a tirania da opinião unânime. No entanto, a autora assevera que nenhuma instituição foi criada para abrigar a liberdade do povo e para possibilitar a renovação da república. Nenhum lugar foi desenhado para acolher e preservar o princípio e o tipo de ação que levaram ao ato fundador, nenhum espaço foi institucionalizado para materializar o espírito revolucionário e abrigar a participação ampliada. ${ }^{66}$

Na perspectiva arendtiana, a Revolução Americana carrega uma ambiguidade com relação à ação do povo, que pode ser bem observada na Declaração de Independência: a expressão "busca da felicidade" presente neste documento não deixa clara a distinção entre felicidade privada e pública. ${ }^{67}$ A primeira, segundo a autora, consiste no bem estar pessoal, na busca de uma certa regulação da sociedade para que os indivíduos desfrutem de independência e sejam estimulados a produzir riqueza, para que não sofram com a necessidade e a escassez. Já a felicidade pública compreende o "direito do cidadão de ter acesso à esfera pública, de ter uma parte no poder público - ser um participante na condução dos assuntos" (Sobre a Revolução, p. 172). De acordo com a autora, a inclusão do direito de busca da felicidade na Declaração de Independência sugeria que nenhum homem poderia ser plenamente feliz sem exercer sua cidadania. Mais do que isso, indicava que, ao organizarem em conjunto a convivência desta nova sociedade e discutirem assuntos comuns, os colonos descobriram este tipo de felicidade.

Para Arendt, esta dupla face da felicidade estava presente nos escritos de Jefferson. Em documento anterior à Declaração de Independência, apresentado na Convenção da Virgínia em 1774, Jefferson expressa sua noção de felicidade pública ao afirmar que aqueles que saíram dos domínios britânicos em direção ao Novo Mundo para estabelecer novas sociedades buscaram instituir leis e ordenações favoráveis para promoção da felicidade pública. ${ }^{68} \mathrm{Na}$ leitura da autora, este pai fundador entendia, assim como seus antepassados, que não era possível ser plenamente feliz apenas fruindo das liberdades

\footnotetext{
${ }^{65}$ Conferir em Sobre a Revolução, p. 290.

${ }^{66}$ Conferir em Sobre e Revolução, p. 171

${ }^{67}$ Conferir em Sobre a Revolução, p. 172-174.

${ }^{68}$ Conferir em Sobre a Revolução, p. 172.
} 
privadas, havia felicidade também em discutir e deliberar sobre os assuntos da comunidade. Desse modo, os escritos de Jefferson dissertaram tanto acerca da felicidade vivida no lar, na convivência com a família, com os amigos e nas atividades privadas quanto da felicidade de tomar parte nos assuntos públicos. ${ }^{69}$ Para a autora, sua ideia de felicidade se revela mais claramente em uma de suas cartas para Adams: "Aqui [na carta] por trás da ironia, temos o explícito reconhecimento de que a vida no Congresso, as alegrias de discursar, de legislar, negociar, persuadir e ser persuadido, eram para Jefferson um antegozo da bem-aventurança eterna [...]" (Sobre a Revolução, p. 177).

Segundo Arendt, bem-aventurança eterna neste sentidos e refere à ação no espaço público que requer a companhia de outros, a ampliação do círculo de amigos; está relacionada com a estima do mundo, ou seja, com o reconhecimento público dos grandes atos de um homem mesmo após sua morte.

Com relação à discussão acerca da felicidade, Starling chama a atenção para a influência do republicanismo inglês na Revolução Norte-Americana: a concepção de felicidade ligada com o mundo público foi originalmente expressa pelos ingleses radicais, especialmente por Harrington. ${ }^{70}$

Arendt reconhece certa influência dos republicanos ingleses na Revolução Americana, sobretudo do pensamento de Harrington. De acordo com ela, este autor, assim como Montesquieu, preparou os homens para o evento revolucionário na medida em que reavivou o espírito público e procurou os exemplos antigos - principalmente da República romana - para pensar a política. ${ }^{71}$ A partir de seu estudo da prudência antiga ele formulou princípios capazes de conferir durabilidade à forma constitucional. Em República de Oceana, a noção de um corpo político federativo é defendida quando o princípio de república por acréscimo é apresentado. ${ }^{72}$ Contudo, a concepção de felicidade pública em Harrington não é tratada. Para Arendt, tal noção surgiu a partir da experiência na colônia e foi formulada e expressa por Jefferson.

Nesse sentido, a autora parece mitigar o peso do republicanismo inglês na América do Norte. Isto pode ser explicado pelo fato de que Harrington, Milton e Sidney estavam

\footnotetext{
${ }^{69}$ Conferir em Sobre a Revolução, p. 174.

${ }^{70}$ Ver em "A Matriz Norte-Americana", p. 266.

${ }^{71}$ Conferir em Sobre a Revolução, p. 284.

${ }^{72}$ Ver em Sobre a Revolução, p. 223 e 259.
} 
preocupados em formular princípios para repúblicas modernas, já os pais fundadores se ocuparam em criar arranjos institucionais condizentes com tais princípios e, com isso, acabaram por alterá-los. Barros esclarece que John Adams, Benjamin Franklin e Thomas Jefferson reproduziram e adaptaram os princípios enunciados pelos republicanos ingleses, tais como direito de resistência, rotatividade nas magistraturas, forma representativa de governo, império das leis, participação cívica, entre outros. ${ }^{73} \mathrm{Em}$ nossa interpretação, Arendt não visa a analisar as influências da teoria política na Revolução Americana, mas busca compreender como certos princípios do pensamento político foram retomados no debate revolucionário e como deram sentido às ações. Este parece ser o motivo pelo qual a autora analisa o significado de felicidade nos textos de Jefferson e não retoma Harrington.

De qualquer forma, segundo Arendt, a conotação pública da felicidade se perdeu. Correia, comentador do pensamento da autora, discute a razão pela qual a felicidade em sentido privado prevaleceu em detrimento de seu aspecto público. Em seu livro Hannah Arendt e a Modernidade, o autor apresenta a tese de que a vitória do animal laborans permanece em nosso tempo, isto é, a mentalidade e o modo de vida dedicados ao consumo ainda são predominantes. Nesse contexto, a crítica de Arendt à valorização do trabalho e da vida como bem supremo e sua defesa da dignidade da atividade política conservam seu vigor. $^{74}$

No que concerne ao livro Sobre a Revolução, Correia trata da ascensão da preocupação com a vida e com o consumo nas revoluções Americana e Francesa e também aponta a possibilidade do gosto pela liberdade levar os homens a se desvencilharem das preocupações estritamente econômicas e a se engajarem nos assuntos políticos. Para ele, do mesmo modo que a emergência da questão social levou a Revolução Francesa à ruína, a busca da felicidade privada conduziu a Revolução Americana ao fracasso: o interesse exacerbado no consumo e no enriquecimento obliterou a felicidade pública nos Estados Unidos da América e provocou o esquecimento da revolução que deu origem ao corpo político do país. ${ }^{75}$ Arendt afirma em $A$ Condição Humana que o consumo não se restringe à satisfação das necessidades vitais, pode também concentrar-se nas superfluidades da

\footnotetext{
${ }^{73}$ Conferir em "A Matriz Inglesa”, p. 171.

${ }^{74}$ Ver em Hannah Arendt e a Modernidade, p. XXX.

${ }^{75}$ Conferir em Hannah Arendt e a Modernidade, p. 192 e 193.
} 
vida, estimular a abundância e a busca pela felicidade pessoal. ${ }^{76}$ Correia, nesse sentido, relaciona a necessidade com a questão social na França e a superfluidade com a questão social na América do Norte. Para reforçar esta relação, ele destaca uma passagem do texto de Arendt frequentemente negligenciada: "[...] a questão social interferiu no curso da Revolução americana com o mesmo grau de intensidade, embora não tão dramaticamente, que teve no curso da revolução Francesa" (Arendt apud Correia, Hannah Arendt e a Modernidade, p. 181).

Segundo o autor, a questão social no Novo Mundo não estava ligada à miséria, mas era (e ainda é) relacionada à obsessão com a abundância. Embora a tirania da necessidade de sobrevivência pareça ser mais opressiva do que a obsessão pela riqueza, ambas reduzem o homem à atividade incessante do trabalho, à preocupação com o consumo. Nas palavras de Arendt, "[...] as cadeias da necessidade não precisam ser de ferro: podem ser feitas de seda" (Arendt apud Correia, Hannah Arendt e a Modernidade, p. 181).

Nesta perspectiva, a Revolução Americana que em um momento é celebrada por ter estabelecido uma constituição duradoura, em outro momento é criticada pelo esquecimento da liberdade política e da participação ampliada. Para Correia, a razão desse malogro se deve à ambiguidade presente na expressão "busca da felicidade" que foi desfeita com a Declaração de Direitos (Bill of Rights). Esta declaração, ao estabelecer direitos cujo conteúdo visava, principalmente, a limitar o poder e salvaguardar a independência dos indivíduos, fez com que a "liberdade fosse finalmente compreendida como liberdade em relação à política e não como direito a tomar parte nela" (Hannah Arendt e a Modernidade, p. 186).

É possível notar que a maioria dos direitos enunciados, como a inviolabilidade da propriedade privada, a liberdade de crença e o direito a um julgamento justo, consistem em limites que o poder não pode transpor: o governo não pode dispor ou tomar a propriedade dos indivíduos, não pode impor uma crença ou religião e não pode prender pessoas arbitrariamente. Segundo Arendt, mesmo a liberdade de expressão, que frequentemente é entendida como um direito relacionado à política, de fato, não garante necessariamente a

\footnotetext{
${ }^{76}$ Ver em A Condição Humana, p. 165.
} 
liberdade de ação, pois não resguarda a liberdade de associação com os concidadãos nem o direito de dissidência. ${ }^{77}$

Somente duas ementas da Declaração de Direitos referem-se estritamente a questões políticas: a primeira, no trecho em que garante o direito do cidadão de enviar petições ao governo, e a décima, que resguarda o poder dos estados frente ao governo central.

Starling esclarece o contexto político da redação e da ratificação da Declaração de Direitos ao mostrar que os antifederalistas, por desconfiarem do poder central e do sistema de representação defendido pelos federalistas, exigiram a inclusão de uma carta de direitos na constituição para impor limites ao governo nacional forte. ${ }^{78}$

De acordo com esta historiadora, os antifederalistas defendiam que os Estados na América do Norte deveriam ser associados por meio de um tratado, não por meio da criação de um poder federal. Eles entendiam que um poder centralizado tende ao excesso, com o tempo irá abusar da autoridade que lhe foi conferida. Para evitar isso era preciso criar diversos poderes e deslocar o poder do centro para a periferia.

O programa antifederalista estava baseado na experiência política do período entre a Declaração de Independência e a ratificação da Constituição, quando não havia governo da União, os Estados possuíam um poder Legislativo mais forte do que o Executivo e os corpos legislativos contavam com grande número de participantes. Nos legislativos estaduais, graças ao aumento considerável do número de votantes, a composição social dos eleitos foi alterada e contava com estratos sociais inferiores da população. ${ }^{79}$

Para Starling, os antifederalistas, quando se deram conta de que seu programa seria derrotado na Convenção Constitucional, defenderam a inclusão da Declaração de Direitos na Constituição com o intuito de salvaguardar os governos estaduais e os cidadãos. Em suas palavras:

“A Carta de Direitos era, de fato, uma solução possível para tornar a participação do cidadão da nova república no mundo público uma realidade tangível. Mas não era uma solução automática; dependia, é certo, de algum grau de virtude como ideal de regulação, mas dependia, especialmente, do gosto da

\footnotetext{
${ }^{77}$ Ver em Crises da República, p. 74.

${ }^{78}$ Conferir em "A Matriz Norte-Americana", p. 301.

${ }^{79}$ Ver em "A Matriz Norte-Americana", p. 280.
} 
liberdade pública ser mantido e cultivado entre os membros da comunidade política" (Starling, "A Matriz Norte-Americana”, p. 304).

$\mathrm{Na}$ concepção de Starling, a obliteração do sentido público de felicidade não foi fruto da Declaração de Direitos. Ao contrário, esta declaração visou a evitar que a participação política ficasse restrita aos representantes do governo federal.

Já na perspectiva de Correia, a Declaração de Direitos na América do Norte falhou em proclamar o direito de participar nos assuntos públicos, isto é, o direito de pertencer ativamente a uma comunidade política. ${ }^{80} \mathrm{Com}$ isso, a dimensão pública da felicidade foi obliterada em prol de sua dimensão privada.

Entendemos que, embora a intenção dos antifederalistas fosse garantir que a participação nos assuntos públicos não se tornasse privilégio dos representantes do Senado e da Câmara Federal, as ementas defendidas por eles foram bem sucedidas em impedir os excessos do poder central, mas não foram capazes de resguardar o gosto da liberdade pública num contexto em que o trabalho e o consumo ganharam tamanha importância.

Correia, para esclarecer o sentido de felicidade privada, retoma as reflexões arendtianas sobre a felicidade em $A$ Condição Humana. De acordo com Arendt, a felicidade na Modernidade - quando a vida se tornou o bem supremo - passou a ser baseada na produtividade: tudo o que favorece o trabalho e alivia a dor e o esforço desta atividade é relacionado com felicidade. O cálculo do prazer e da dor de Bentham é, para a autora, o pensamento que representa a preocupação com a sobrevivência, o afastamento do espaço público para a dedicação exclusiva às atividades econômicas. Segundo Arendt, o pressuposto básico de Bentham consiste em que "[...] o que todos os homens possuem em comum não é o mundo, mas a uniformidade de sua própria natureza, o que se manifesta na uniformidade dos cálculos e na uniformidade com que todos são afetados pela dor e pelo prazer [...]" (A Condição Humana, p. 386).

Podemos depreender desta discussão acerca da felicidade que este termo também possui historicidade: para os republicanos ingleses do XVII e no início da Revolução Americana, felicidade carregava tanto um sentido público quanto privado. Mas na

\footnotetext{
${ }^{80}$ Conferir em Hannah Arendt e a Modernidade, p. 190 e 191.
} 
passagem do século XVIII para o XIX, o pensamento liberal ganha força e o sentido público do termo é progressivamente esquecido. ${ }^{81}$

Nesse contexto, para a autora, o evento revolucionário na América do Norte carregou uma ambiguidade desde seu início, o direito à "busca da felicidade" enunciado na Declaração de Independência podia ser interpretado como direito de participação ou como dever do governo de estimular a economia. De acordo com Correia, a Declaração de Direitos na América desfez esta ambiguidade ao garantir as liberdades individuais e ao negligenciar a liberdade política.

Embora o autor esteja preocupado com a relação entre a ascensão da mentalidade do animal laborans e o fracasso da Revolução Americana, ele aponta para um problema político que contribui para a valorização exacerbada da atividade econômica. Dito de outra forma, o malogro em resguardar o espírito revolucionário e em salvar do esquecimento a ação revolucionária não dizem respeito exclusivamente ao aparecimento da questão social, mas está ligado, em primeira instância, à política, especificamente ao estabelecimento de direitos.

Ao nosso ver, outra questão política contribuiu para a redução do espaço político ao final da Revolução Norte Americana: além do direito de associação e de dissidência não terem sido declarados e registrados em um documento público, nenhuma instituição foi criada para abrigar a ação e a participação ampliada. O novo corpo político não institucionalizou o espaço onde cada cidadão poderia de fato se tornar participante no governo e nos assuntos públicos. Levando isso em conta, entendemos que o principal fator que levou ao malogro das revoluções é político. As questões econômicas e sociais, embora tenham desempenhado um papel neste evento revolucionário, não determinaram seu rumo. ${ }^{82}$

Vimos acima que, para Starling, os revolucionários no Novo Mundo entendiam que, uma vez resguardados os direitos civis e garantidos a liberdade de expressão e o direito de peticionar ao governo, a participação dependeria do desenvolvimento de virtudes cívicas. Os homens engajados no evento revolucionário na América do Norte

\footnotetext{
${ }^{81}$ No início do século XIX, além de Bentham, Benjamim Constant celebra a felicidade privada, ou melhor, os prazeres da independência individual.

${ }^{82}$ Se Arendt entendesse que as questões sociais determinaram as Revoluções Americana e Francesa, ela teria que concordar com Marx, em que a política é uma superestrutura regulada pela economia.
} 
compartilhavam a ideia de que, depois de terem experimentado a liberdade, eles procurariam mantê-la. ${ }^{83}$

Arendt não parece confiar tanto assim na disposição humana em apreciar a liberdade pública e em desenvolver a virtude cívica. A autora, como bem sublinhou Waldron, não trata somente da espontaneidade e do virtuosismo da ação, mas indica também que a atividade política precisa de estruturas, instituições e normas. De acordo com este autor, a maioria dos comentadores do pensamento arendtiano acentua o aspecto espontâneo e agonístico do agir em detrimento dos aspectos institucionais e constitucionais da ação. ${ }^{84}$ Tendo isso em vista, consideramos que Arendt aponta que a Revolução Norte Americana falhou em fundar instituições destinadas a abrigar dissidência popular e a ação ampliada. Nesta perspectiva, os homens podem e devem criar espaços públicos e leis que favoreçam a felicidade pública, que aprimorem as virtudes cívicas. Sem instituições que abriguem a ação e o debate dos cidadãos, o gosto pela liberdade pública não se concretiza como experiência regular e duradoura.

Manin, de certo modo, também trata do esquecimento da felicidade pública apontado por Arendt ao considerar que a principal herança da experiência revolucionária norte-americana foi a criação do sistema representativo e ao apontar uma tendência do princípio de distinção de gerar um governo voltado para a felicidade privada, a geração de riqueza e o desenvolvimento da economia. $\mathrm{O}$ autor mostra que os antifederalistas sabiam que a representação, da forma em que foi estabelecida pela Constituição, poderia ser distorcida e que o governo poderia favorecer as classes mais ricas. Eles denunciavam a tendência oligárquica da Constituição, que poderia conferir privilégio legal não só aos mais talentosos para as tarefas políticas, mas também aos que possuíam mais riqueza e mais status social. $^{85}$

Já para os federalistas, na leitura de Manin, a Constituição favorecia o surgimento de uma aristocracia natural em que seriam escolhidos para governar a comunidade os homens mais sábios e virtuosos dentre os cidadãos. Nesta perspectiva, o poder no governo aristocrático não é exercido pelo povo, mas por um seleto grupo de homens proeminentes

\footnotetext{
${ }^{83}$ Conferir em "A Matriz Norte-Americana", p. 305.

${ }^{84}$ Conferir em "Arendt's Constitutional Politics", p. 202.

${ }^{85}$ Conferir em "O princípio de distinção", p. 205.
} 
que se destacam antes por suas qualidades pessoais do que por suas riquezas ou posses territoriais. $^{86}$

Hamilton foi o federalista responsável por ligar o princípio de distinção com as classes mais abastadas. Embora ele reconhecesse que a riqueza desempenha um papel importante nas eleições dos representantes, alegou que isto se dá por causas naturais: a Constituição de forma alguma tornou um homem rico mais elegível do que um pobre. Além disso, ele não considerava um problema para a república a facilidade dos detentores de riqueza de se elegerem. Ao contrário, segundo Hamilton, as classes abastadas são menos torpes do que as classes pobres. Em suas palavras: “[...] a vantagem de caráter pertence aos ricos. Seus vícios são provavelmente mais favoráveis à prosperidade do Estado do que dos indigentes, e eles [os ricos] compartilham menos depravação moral" (Hamilton apud Manin, “O princípio da distinção”, p. 213).

Hamilton, nesse sentido, considerava que a influência da riqueza na seleção dos governantes não era algo ruim: para ele, negociantes prósperos e industriosos, ao dirigirem os Estados Unidos, iriam contribuir para a grandeza histórica do país. A partir disso, é possível identificar uma relação entre o princípio de distinção e a defesa de um governo oligárquico que tem como principal objetivo o desenvolvimento da economia e a promoção da riqueza. Não é por acaso que este federalista foi nomeado o primeiro secretário do tesouro dos Estados Unidos, participou ativamente da criação dos dois primeiros bancos nacionais e usou sua influência para promover os setores financeiros e comerciais.

Levando isso em conta, podemos concluir que, entre os pais fundadores, alguns davam mais importância para a felicidade privada e colocavam o governo a serviço do desenvolvimento econômico e bem estar individual, enquanto outros, como Jefferson e alguns dos antifederalistas, estavam engajados em resguardar a felicidade pública, garantir a participação ampliada em diferentes instituições.

Conforme Manin, esta visão de Hamilton não era aceita por todos os federalistas:

"Nos anos 1790, Madison e Hamilton encontravam-se em campos opostos: este último, então no governo, continuou a favor dos interesses comerciais e financeiros e a defender um poder central forte; ao passo que Madison juntou-se a Jefferson na denúncia do que ambos consideravam como corrupção associada às finanças e ao comércio, assim como abusos do governo federal" ("O princípio da distinção", p. 214).

\footnotetext{
${ }^{86}$ Ver em "O princípio de distinção", p. 212 e 213.
} 
De acordo com Arendt, Jefferson, anos após a revolução, quando já havia se retirado da vida política, apercebeu-se de que a revolução tinha falhado em prover uma instituição para o espírito que a inspirou - a liberdade - e para o tipo de ação que a originou - a ação nas assembleias municipais. Para ele, estes órgãos políticos não eram provisórios, não consistiam apenas em um meio de realizar a revolução, eram a origem de uma nova forma de governo. A Constituição não incorporou as organizações civis que originaram e levaram a cabo o levante revolucionário, ela transferiu para Washington e para os governos estaduais os espaços de debate e decisão dos negócios públicos, suprimindo assim a possibilidade de cada um ser participante do governo. Nesta perspectiva, para Arendt, a revolução libertou o povo de um governo opressor, mas não estabeleceu a liberdade enquanto realidade tangível, já que apenas um pequeno grupo (os representantes do povo) tinha o privilégio de agir, debater e decidir. ${ }^{87}$

Conforme foi indicado na introdução desta tese, a Revolução Americana atualmente se tornou modelo de criação de governo representativo. Para Manin, o princípio de distinção foi exposto claramente no debate constitucional norte-americano: a noção de que o sistema representativo está baseado em uma desigualdade foi expressa no debate entre federalistas e antifederalistas. Estes defendiam a concepção de que os representantes deveriam ser similares aos seus eleitores. Dessa forma, seria possível estabelecer um governo popular, já que, em virtude da similaridade entre representantes e representados, os governantes agiriam do mesmo modo que o povo, se este último pudesse ser reunido em uma assembleia. Esta concepção foi derrotada em 1787 pela noção de representação federalista, que entendia que "os representantes deveriam ser diferentes de seus representados, e situar-se acima deles em termos de talento, virtude e riqueza" (Manin, "O princípio da distinção", p. 223).

Na perspectiva de Manin, o princípio de distinção é capaz de gerar um governo popular uma vez que os representantes são escolhidos pelo povo e em cada eleição devem prestar contas de suas ações.

Já na concepção de Jefferson, referendada por Arendt, na América foi estabelecida uma democracia abstrata, pois se trata de uma democracia que garante a representação de todos sem conferir concretude à participação de cada um. Isto poderia degenerar o novo

\footnotetext{
${ }^{87}$ Conferir em Sobre a Revolução, p. 295-297.
} 
corpo político em um despotismo eletivo. De acordo com a autora, este despotismo poderia conduzir à corrupção, não no sentido de que o poder público expande seus domínios sobre a vida privada, já que a Constituição Norte-Americana foi bem sucedida em estabelecer um governo limitado e balancear os poderes. Depois da ascensão da esfera social, a corrupção passa a ser caracterizada também pela invasão dos interesses privados nos assuntos públicos. Assim, o despotismo eletivo significaria o risco dos poucos representantes darem preferência a interesses privados e econômicos em detrimento do bem público.

Segundo a autora, Jefferson, tendo este risco em vista, passou a defender em seus escritos tardios a criação de um sistema distrital [ward system] para evitar a degeneração do governo. Para ele, isto significava incluir órgãos civis e assembleias municipais no sistema de poder. Além disso, este pai fundador sugeriu criar um mecanismo periódico de revisão da Constituição. Madison e Hamilton, ao contrário, entendiam a Constituição como algo imutável. No entanto, Jefferson alegava que nada deveria ser imutável além dos direitos inerentes e inalienáveis dos homens. ${ }^{88}$ Para ele, a escolha da forma de convivência na comunidade e a instituição de ordenamentos não podem ser o privilégio de uma só geração, as gerações vindouras deveriam ter o direito de escolher a forma de governo mais adequada para si. Por isso, a Constituição deveria dispor de um modo de revisão constitucional periódico. ${ }^{89}$

No debate constitucional do Estado de Virgínia, Jefferson já havia proposto um dispositivo para alterar e corrigir a Constituição quando fosse necessário: uma convenção deveria ser formada para reavaliar a Carta Constitucional deste Estado se todos os três ramos de poder votassem a favor de uma revisão constitucional, cada um com maioria de dois terços do total. Mais tarde, em uma carta destinada a Madison, ele defende a revisão periódica das leis a cada dezenove anos. De acordo com Jefferson, uma geração não tem o direito de vincular a outra, isto é, os homens que governam hoje não devem deixar dívidas e incumbências para as gerações futuras. Em sua perspectiva, as Constituições e as leis não devem ser perpétuas, elas naturalmente expiram: uma maioria, quando delibera e cria uma lei, vincula o todo da sociedade, mas uma maioria não vive para sempre, por isso, os atos

\footnotetext{
${ }^{88}$ Esta é a única menção que a autora faz ao debate entre os federalistas e Jefferson, embora este debate e a derrota de Jefferson e dos antifederalistas tenham definido os contornos do tipo de representação adotado no corpo político norte-americano.

${ }^{89}$ Sobre a Revolução, p. 293 e 295.
} 
de uma sociedade são limitados no tempo. As próximas gerações devem ter o poder de revogar as leis e criar seus próprios ordenamentos. ${ }^{90}$

Madison já havia, nos artigos 49 e 50 de $O$ Federalista, rejeitado a noção de revisão constitucional tanto em ocasiões extraordinárias quanto em períodos previamente fixados. Em suas palavras, “À primeira vista, recorrer ao povo em períodos fixos parece ser quase tão inconveniente como fazê-lo cada vez que surgir uma necessidade". ${ }^{91}$ De acordo com ele, o apelo ao povo para revisar a Carta Constitucional iria favorecer facções e poderia desequilibrar o correto entrelaçamento dos três ramos do poder. Além disso, em resposta à carta de Jefferson, o federalista afirma que a constituição de um governo e algumas leis são irrevogáveis. Ele ainda argumenta que é natural que uma geração tenha vínculos e obrigações para com a outra e, nesse sentido, uma geração deve procurar deixar mais benefícios para a posteridade do que dívidas e incumbências. Para tanto, conforme Madison, a Constituição federal é bem ordenada e dotou o governo de freios que impedem a geração atual de impor um fardo injusto e desnecessário às gerações futuras. ${ }^{92}$

As propostas de Jefferson de inscrever na Constituição o sistema distrital, mecanismos de recurso ao povo em caso de necessidade e de revisão periódica das leis fundamentais não foram levadas adiante. Para Arendt, isso se deve em parte ao fato de que este pai fundador percebeu algumas falhas nas instituições do corpo político depois da Convenção Constitucional, além disso, a autora indica que ele mudou sua concepção de ação. Jefferson identificava inicialmente ação e rebelião, isto é, agir significava contestar o governo, divergir da autoridade, revogar leis. No fim de sua vida, contudo, a autora atesta que este pai fundador passou a interpretar a ação como sinônimo de constituir, de criar algo novo. ${ }^{93}$ Esta mudança, segundo a autora, é a razão pela qual ele passou a defender a participação no governo e mecanismos institucionais para renovar a constituição republicana.

\footnotetext{
${ }^{90}$ Ver em carta de Jefferson para Madison de 6 de setembro de 1789. Disponível em http://presspubs.uchicago.edu;founders. Último acesso em 15 de dezembro de 2015. Para Arendt, Jefferson não pretendia com esta proposta de revisão constitucional que a república fosse colocada em xeque por cada geração e que se pudesse desmontá-la em prol da monarquia ou aristocracia, antes ele propunha que as opiniões do povo pudessem ser consideradas e discutidas de forma mais ampla. Conferir em Sobre a Revolução, p. 296.

${ }^{91}$ O Federalista, artigo 50, p. 413.

${ }^{92}$ Conferir em carta de Madison para Jefferson de 4 de fevereiro de 1790. Disponível em http://presspubs.uchicago.edu;founders. Último acesso em 15 de dezembro de 2015.

${ }^{93}$ Ver em Sobre a Revolução, p. 296.
} 
Levando as ideias dos Pais Fundadores em conta, Arendt tece a explicação do curso e da herança deixada pela Revolução Americana. Para a autora, este evento revolucionário foi bem sucedido em estabelecer uma Constituição duradoura. Como já foi mencionado, a Suprema Corte e o Senado garantem a durabilidade do corpo político enquanto que o sistema de poder baseado no federalismo une Estados e União e permite a formação de um governo republicano em vasto território. Contudo, esta revolução foi mal sucedida para estabelecer a liberdade dos cidadãos e resguardar o direito de cada um de participar nos assuntos comuns. Nesse sentido, a República norte-americana é reconhecida por sua estabilidade e por possibilitar a busca da felicidade privada, isto é, o governo permite que os indivíduos persigam seu bem-estar individual e a produção de riqueza. De acordo com Arendt, o esquecimento da felicidade pública, da participação ampliada que deu início e levou a cabo a fundação de uma república no Novo Mundo, provocou o esquecimento da própria revolução. A tradição revolucionária não incorporou a Revolução Americana em seu campo de reflexão e a tornou estéril politicamente. ${ }^{94}$

\subsection{Líderes da Revolução Francesa}

Dentre as figuras importantes da Revolução Francesa, Arendt, embora cite Condorcet, destaca, sobretudo, a atuação e as concepções de Sieyès e Robespierre. A autora procura entender esta revolução, seu curso e seu desfecho principalmente por meio das referências políticas dos revolucionários mais eminentes.

$\mathrm{Na}$ perspectiva da autora, um evento político só pode ser considerado revolucionário quando visa mais do que a garantia de direitos civis e a libertação da opressão, quando procura estabelecer também a liberdade enquanto participação nos assuntos públicos. A revolução na França, em seu início, visava à constituição de um novo corpo político que resguardasse a liberdade. De acordo com Arendt, Condorcet compreendeu a experiência francesa a partir de 1789 pelo menos até 1793 ao enunciar que o objetivo da revolução era a liberdade. ${ }^{95}$ Robespierre reconheceu a importância da

\footnotetext{
${ }^{94}$ Conferir em Sobre a Revolução, p. 275 e 279.

${ }^{95}$ Ver em Sobre a Revolução, p. 56.
} 
participação política no momento em que definiu o governo revolucionário como despotismo da liberdade e defendeu as comunas, clubes e sociedades populares como os espaços capazes de sustentar a constituição republicana: eles resguardavam o debate que instruía e esclarecia os cidadãos sobre os princípios da república. Robespierre, além de relacionar revolução e liberdade, associava revolução com novidade: em sua concepção tudo havia mudado na área científica e filosófica e deveria mudar também no campo político. $^{96}$

Contudo, esta revolução não foi bem sucedida na fundação de um corpo político duradouro que garantisse a liberdade política. A liberdade e o debate ampliado experimentado em seu início foram suplantados pela centralização, pela redução do espaço público e pelo uso da violência. Conforme Arendt, a emergência da questão social complicou a tarefa dos homens públicos na França, uma vez que enfrentaram ao mesmo tempo o desfio de estabelecer um novo corpo político e procuraram uma forma de acabar com a miséria. Isso não significa, entretanto, que a questão social foi a principal causa do fracasso da Revolução Francesa em instituir uma república duradoura.

A associação entre a questão social e o fracasso da revolução é estabelecida por alguns autores. Por exemplo, Benhabib e Duarte defendem que o sucesso da Revolução Americana em estabelecer uma constituição duradoura foi resultado da ausência da questão social: os revolucionários não se desviaram das questões políticas uma vez que a miséria e a escravidão não se tornaram assuntos públicos naquele momento, foram enfrentadas anos mais tarde, na Guerra de Secessão. Já na Revolução Francesa, de acordo com estes comentadores, o surgimento das massas de famintos no espaço público destruiu paulatinamente os espaços políticos e levou a revolução ao terror.

Segundo Benhabib, Arendt separa as questões políticas e sociais a partir do critério de conteúdo: a política se refere à liberdade e está ligada à ação, enquanto o social diz respeito à necessidade e está vinculada com a administração. Dessa forma, quando a miséria na França se tornou tema dos debates públicos, a questão de como estabelecer a liberdade foi esquecida em prol da satisfação das necessidades de sobrevivência. Neste contexto, a ação foi abandonada em favor da administração. ${ }^{97}$

\footnotetext{
${ }^{96}$ Conferir em Sobre a Revolução, p. 56 e77.

${ }^{97}$ Conferir em The Reluctant Modernism of Hannah Arendt, p. 157-158.
} 
Duarte articula a questão social com violência e terror. Para o autor, a miséria exige decisões rápidas e o atendimento imediato das necessidades vitais, por isso não admite o longo processo de debate e deliberação próprios do espaço político. Nesta perspectiva, quando os revolucionários na França se comprometeram em sanar a questão social, negligenciaram a ação ao recorrerem a medidas rápidas e extraordinárias as quais não estavam limitadas por leis, descartavam o debate e a participação e eram afeitas a meios violentos. ${ }^{98}$

Em nossa interpretação, Arendt indica que foram as concepções políticas que levaram os revolucionários francesa não estabelecer marcos confiáveis para a vida política e a favorecer a centralização das decisões e o recurso à violência. Além disso, veremos abaixo que as concepções de vontade geral, nação, soberania e fundação balizaram a forma de abordar a questão social publicamente.

Segundo a autora, as ideias de nação, vontade e soberania tornaram impossível o equilíbrio e estabilidade do corpo político; e, ainda, favoreciam a centralização das decisões na Assembleia Nacional. Já a piedade como virtude foi a forma de reduzir a pluralidade de opiniões a uma unanimidade e de perseguir dissidentes e questionadores. Por fim, a concepção de fundação como fabricação, além de promover a centralização do poder em uma só pessoa, justificou o uso de medidas extraordinárias e violentas.

Para Arendt, da mesma forma que os revolucionários norte-americanos, os franceses também procuraram auxílio na filosofia política para conceber a nova forma de governo que se buscava estabelecer. O pensamento de Montesquieu fazia sentido dentro das concepções e experiências dos homens do Novo Mundo, já no caso francês, especificamente para Sieyès e Robespierre, o pensamento de Rousseau poderia auxiliar na constituição da república. É importante lembrar que Bignotto aponta para o fato de que não apenas Robespierre e Sieyès retomaram o pensamento de Rousseau, outras figuras, até mesmo monarquistas citavam conceitos do pensador genebrino. ${ }^{99}$

O dilema enfrentado por Rousseau - sua famosa imagem da quadratura do círculo era semelhante ao círculo vicioso de Sieyès, que se deparou com o problema de por a lei acima dos homens. A perplexidade consistia em considerar as leis como algo superior,

\footnotetext{
${ }^{98}$ Ver em O Pensamento à Sombra da Ruptura, p. 273-285.

${ }^{99}$ Conferir em "Hannah Arendt e a Revolução Francesa", p. 50.
} 
embora feitas por homens que se encontravam fora de uma ordem constitucional préestabelecida. Em outras palavras, Sieyès se deparou com o problema da relação entre poder constituinte e poder constituído. Para usar os termos de Kalyvas, o autor tentou lidar com a relação e tensão entre a política ordinária e a extraordinária. ${ }^{100}$ No entanto, Sieyès buscou um elemento externo à política para solucionar os problemas da criação da lei humana e da arbitrariedade inerente a toda fundação: buscou um absoluto para transmitir autoridade às leis. ${ }^{101}$ Este revolucionário colocou a nação como fonte do poder e da autoridade. A concepção de nação pressupõe um nascimento comum e características comuns, nesse sentido, a nação está ligada ao estado de natureza, ela é anterior e externa à política.

Arendt assevera que a fundação é um início e todo início carrega consigo certa arbitrariedade por não ser decorrência de nenhuma lei histórica ou consequência de uma cadeia de fatos. O início surge da ação em conjunto e, por isso, porta certo grau de contingência. De acordo com a autora, Sieyès, ao relacionar o poder constituinte com a categoria de nação, tentou escapar da arbitrariedade e contingência próprias do início. Para Kalyvas, os homens da Revolução Francesa, quando foram confrontados com o problema da legitimidade dos novos inícios, responderam à questão com a fórmula da vontade da nação. A concepção de nação pressupõe um nascimento e características comuns, assim, ela está ligada à natureza e é anterior e externa à política. O problema do início parecia ser resolvido ao se estabelecer um iniciador cuja origem não é sujeita à questão: a nação, como elemento do estado de natureza, consiste em algo dado, portanto está fora de questionamento. ${ }^{102}$

De acordo com Arendt, um dos problemas dos homens da Revolução Francesa foi identificar povo com nação. Como foi mencionado acima, povo, no Novo Mundo, era uma categoria política, indicava que as pessoas têm qualidades distintas e possuem diferentes pontos de vista, portanto, dizia respeito à pluralidade. Nesse sentido, o poder constituinte foi entendido como plural, ele surgiu da ação em diversas instâncias, das assembleias municipais, provinciais entre outras. Além disso, ao relacionar povo e pluralidade, o poder constituinte é entendido como algo pertencente ao campo político e não como algo que se

\footnotetext{
${ }^{100}$ Ver em Kalyvas, Democracy and the Politics of the Extraordinary, p. 6-8.

${ }^{101}$ Conferir em Sobre a Revolução, p. 208, 212 e 238.

${ }^{102}$ Conferir em Kalyvas, Democracy and the Politics of the Extraordinary, p. 215.
} 
localiza no estado de natureza. Apesar deste poder surgir de espaços públicos extraconstitucionais, que foram instituídos antes ou fora de uma constituição, ele é artificial, nasce por meio da ação e discurso entre os homens. Ao contrário, a noção de nação está ligada à natureza, esta categoria indica que um grupo de pessoas tem em comum o lugar de nascimento e, nessa medida, aponta para certa homogeneidade e uniformidade entre elas. Em razão desta uniformidade, o poder de uma nação, para ser exercido, não precisa mais do que uma instituição.

Os revolucionários, quando passaram a entender o povo como uma massa homogênea que possuía uma mesma vontade, viram na noção rousseauniana de vontade geral um modelo para estabelecer o governo. Sieyès, de acordo com Arendt, foi o teórico de maior destaque na Revolução Francesa. Ele substituiu, teoricamente falando, a soberania do rei pela soberania da nação: assim como a vontade do rei tinha sido a fonte da lei no absolutismo, a vontade da nação deveria ser a fonte da lei na república. ${ }^{103}$ Nesse sentido, o autor baseou seu pensamento na concepção hebraica e cristã de lei. Como foi dito anteriormente, esta concepção entende que a fonte da lei é a vontade de Deus e consiste em um mandamento que exige obediência. Com a secularização, a fonte da lei passou a ser a vontade do governante. Se, para Sieyès, a nação institui a república, sua vontade é a fonte da lei.

Na perspectiva de Sieyès, a nação tem a posse do poder constituinte, isto é, tem a potência de estabelecer o poder constituído - a Assembleia Nacional. Segundo ele, esta instituição tem o papel de representar a nação e redigir as leis civis. Vale destacar que a concepção de nação tornou possível relacionar a vontade geral de Rousseau com a representação na Assembleia Nacional: somente identificando o povo à nação, a vontade geral pode dispensar a participação dos indivíduos autônomos e ser passível de representação. Nesta perspectiva, tanto o poder quanto as leis se ancoram na nação: o poder constituído é estabelecido por ela e a lei está de acordo com sua vontade.

Segundo Kalyvas, esta operação de Sieyès, que relaciona soberania à nação e à vontade geral, tornou o poder irrestrito. A soberania, quando foi assentada na nação, foi jogada para fora da esfera política e passou a ser relacionada com o estado de natureza, nesse sentido, tornou-se isenta das restrições e limitações legais e institucionais. Ora, se a

${ }^{103}$ Ver em Sobre a Revolução, p. 205. 
soberania e a vontade geral não estão reguladas e constrangidas pela lei, não é acidental que a violência seja usada. Para o autor, Arendt estava preocupada com a dimensão extralegal da soberania, que ameaça a liberdade das pessoas engajadas na política extraordinária. ${ }^{104}$

A crítica de Arendt à noção de soberania é fundamentada na definição tradicional de vontade. Como já foi mencionado no capítulo anterior, a vontade foi entendida na tradição como livre-arbítrio. Ela é livre na medida em que escolhe entre coisas sem ser coagida pela razão ou pelas paixões. A autora, com base no pensamento de Agostinho, indica que a vontade só pode conter um impasse ao dividir-se entre querer e não querer e que em um dado momento ela se decide e ordena a si mesma. Nesse sentido, a vontade está relacionada com autodomínio e autogoverno. ${ }^{105}$ Relacionada à noção de soberania, a vontade, além de promover a identificação entre ser livre e ser soberano, fez com que soberania passasse a significar governar os outros como se governa a si mesmo, isto é, nos moldes da vontade: quando há um impasse, a vontade do governante deve ser imposta de modo que acabe com as outras, não há espaço para resistência. Segundo Arendt, uma vez que a vontade pertence ao interior do sujeito, ela não pode ser intercambiada ou mediada, por isso, não é possível estabelecer um acordo entre as vontades de diversas pessoas. Somente é possível impor uma vontade contra as demais. Por esta razão, para a autora, ela não é uma categoria adequada à vida política, pois fatalmente leva à dominação e à hierarquização.

É importante observar que Arendt mantém quase a mesma crítica com relação ao conceito de vontade entendida como liberdade em toda sua obra, entretanto, o mesmo não ocorre no que diz respeito à soberania. Em A Condição Humana, a autora, apesar de criticar a ligação entre vontade e soberania, menciona um tipo de soberania que está relacionada a um acordo mútuo que elege um propósito comum e mantém as pessoas unidas. Neste livro, a autora aponta que a soberania pode ser entendida com a independência limitada de um grupo que possui um mesmo propósito. ${ }^{106}$ Esta conexão

\footnotetext{
${ }^{104}$ Ver em Democracy and the Politics of the Extraordinary, p. 216-218.

105 Sobre a divisão da vontade, conferir em A Vida do Espírito, p. 255 e 256. Acerca da relação entre vontade e autodomínio, ver em A Condição Humana, p. 292.

${ }^{106}$ Ver em A Condição Humana, p. 306.
} 
entre soberania e acordo mútuo não é retomada ou desenvolvida em Entre o Passado e o Futuro e em Sobre a Revolução. No artigo intitulado “Que é liberdade?”, a autora afirma:

"Onde os homens aspiram a ser soberanos, como indivíduos ou como grupos organizados, devem se submeter à opressão da vontade, seja esta a vontade individual com a qual obrigo a mim mesmo, seja a 'vontade geral' de um grupo organizado. Se os homens desejam ser livres, é precisamente à soberania que devem renunciar" (Entre o Passado e o Futuro, p. 213).

Já em Sobre a Revolução, Arendt, a propósito da sua análise da Revolução Francesa, mostra como a ligação entre vontade e soberania obliterou a liberdade política e a pluralidade do povo. Ainda, a autora indica como tal ligação impossibilitou a durabilidade das leis e das instituições na França. Ela ressalta que a vontade, além de ser subjetiva e imperativa, é volúvel, isto é, muda constantemente. Em sua perspectiva, uma república fundada na vontade é uma estrutura apoiada em areia movediça. ${ }^{107}$ De acordo com Kalyvas, levando em conta que a característica da vontade é sua inconstância e volubilidade, a categoria de vontade geral fragiliza a estabilidade das instituições. ${ }^{108}$

Para a autora, a tentativa de estabelecer uma lei de acordo com a vontade fez com que nenhuma Constituição fosse duradoura: na França pós-1789 seguiu-se uma Constituição atrás da outra e o governo revolucionário não pode obter estabilidade até que um ditador - Napoleão Bonaparte - intitulasse a si mesmo como representante da vontade geral e possuidor do poder constituinte. ${ }^{109}$ De acordo com Arendt, a lei deve estar ancorada no debate público, isto é, na troca de opiniões que é capaz de depurá-las e formar princípios e interesses compartilhados.

Nesse sentido, Arendt, ao olhar para o curso da Revolução Francesa, entende que a vontade da nação como fonte da lei acaba por não estabilizar a vida política e desemboca na noção de revolução contínua. A revolução como lei foi elaborada teoricamente por Condorcet. ${ }^{110}$ Para ele, a lei tem como objetivo acelerar ou regular o andamento da revolução até o momento em que ela se completa. Segundo Arendt, no entanto, um processo revolucionário que se torna uma lei em si mesma não pode se completar, uma vez que se torna um movimento sem fim - uma revolução permanente - e apenas pode ser parado por um movimento contrarrevolucionário. Napoleão Bonaparte foi, nesta

\footnotetext{
${ }^{107}$ Ver em Entre o Passado e o Futuro, p. 212.

${ }^{108}$ Conferir em Kalyvas, Democracy and the Politics of the Extraordinary, p. 218.

${ }^{109}$ Ver em Sobre a Revolução, p. 214.

${ }^{110}$ Ver em Sobre a Revolução, p. 238.
} 
perspectiva, aquele que pôs fim ao movimento revolucionário. De acordo com a autora, ele se manteve no poder por um longo período porque governou em favor do interesse da sociedade de classe que emergiu depois da desestruturação dos antigos estamentos, ele não pautou seu governo em algo abstrato e volúvel como a vontade geral.

Além de Sieyès, Robespierre também entendia que o bom governo deveria estar de acordo com a vontade da nação. Sua ditadura visou a organizar todo o povo dentro de uma única estrutura de poder e adequar as diversas opiniões a uma vontade unânime, pois só seria possível governar segundo a vontade se esta for una e indivisível. ${ }^{111}$ Arendt esclarece que a vontade, quando está dividida, gera um impasse, ninguém consegue decidir como agir. Vale repetir que, de acordo com a autora, não é possível um acordo entre vontades diferentes, pois a vontade é imperativa, deve se impor para gerar ação. Em contraste, quando a lei é baseada na opinião, a decisão de como agir se dá por meio da deliberação no debate público, que é possível mesmo onde há divergências. Nesse sentido, na medida em que as noções de vontade geral e soberania foram adotadas na França, o debate foi abandonado em favor da imposição de uma vontade unânime.

Kalyvas sublinha que a noção de soberania, intimamente ligada à de vontade, abole a pluralidade de opinião, uma vez que não implica o debate e a deliberação entre iguais, mas requer aclamação. ${ }^{112}$ A soberania, para ser una e indivisível, precisa acabar com poderes paralelos e opiniões distintas. Por esta razão, esta concepção carrega em si o germe da perseguição de 'inimigos' e da guerra civil. Ela transforma a política em um campo de batalhas ao postular aqueles que discordam e divergem como o outro, o inimigo.

De acordo com Arendt, a política se transformou em um campo de batalhas sangrento quando Robespierre ascendeu ao poder e elegeu a piedade como a principal virtude pública. A piedade teve um papel central para produzir uma vontade unânime: se a massa de miseráveis já possuía uma mesma vontade - em razão de sua necessidade de pão -, os demais franceses, aqueles que não estavam sob a opressão da pobreza, deveriam abandonar suas opiniões, vontades e interesses particulares, e, por meio da compaixão e piedade, adotar a mesma vontade das massas famintas. Nesse sentido, para sanar a questão

\footnotetext{
${ }^{111}$ Conferir em Sobre a Revolução, p. 111-113.

112 Neste ponto Kalyvas afirma que Arendt endereça uma crítica a Schmitt: a soberania popular só pode existir por aclamação. Em Democracy and the Politics of the Extraordinary, p. 220.
} 
social, além de uma estrutura de poder centralizada e do fim do debate e ação fora da Assembleia Nacional, os revolucionários deveriam fazer “[...] um esforço de solidarização que Robespierre chamou de virtude, e essa virtude não era romana, não visava a res publica e não tinha nada a ver com a liberdade. Virtude significava pensar no bem-estar do povo [...]" (Sobre a Revolução, p. 111). É importante destacar aqui que a noção de soberania guarda uma conexão com a virtude da piedade na medida em que a piedade produz autodomínio, ou seja, faz com que todos abneguem seus desejos em favor da vontade dos miseráveis e, dessa forma, ela se torna imperativa, algo que governa todos os homens.

Robespierre, a partir de então, ao dizer povo não designava uma multiplicidade de agentes, uma pluralidade de pessoas, mas se referia a uma massa homogênea de miseráveis. Uma vez que os homens em condição de miséria são iguais, ficam reduzidos às mesmas necessidades biológicas, pois precisam das mesmas coisas para sobreviver, a condição de pobreza parecia confirmar esta identificação entre povo e homogeneidade. Segundo Arendt, se esta concepção de povo como uma massa que se move como um só corpo e age como que possuída por uma só vontade se difundiu, “[...] não foi por causa de nenhuma influência teórica abstrata, mas devido a sua óbvia plausibilidade em condições de miséria extrema" (Sobre a Revolução, p. 134).

Segundo a autora, mesmo Sieyès, uma das figuras mais sóbrias da revolução, declarou que o povo era sempre miserável, identificou povo com uma multidão de sofredores e também passou a pregar a compaixão e a piedade.

De acordo com Arendt, a compaixão consiste em um tipo de paixão que é despertada pelo sofrimento de uma pessoa em particular, por uma situação concreta e conhecida. As paixões, nesse sentido, são inevitáveis: quando se é exposto a uma situação de risco fatalmente se sente medo, quando se vê o sofrimento alheio, sente-se compaixão. Para Arendt, não se pode resistir às paixões uma vez que elas são reações naturais. A autora usa as palavras de Rousseau para indicar isso: para o autor, a compaixão é a "repugnância inata do homem em ver o semelhante sofrer" (Sobre a Revolução, p. 119).

Podemos notar que a compaixão, como qualquer outra paixão, refere-se a pessoas e situações particulares, não pode haver paixão por um grupo, ou uma classe, ou um povo. Levando isso em conta, a compaixão não pode abarcar a situação de pobreza em massa que 
foi exposta publicamente na Revolução Francesa. Só uma categoria geral, como a piedade, seria capaz de abranger todos os infelizes e miseráveis da França. Para Arendt, a piedade é uma distorção da compaixão: ela consiste em uma operação da razão que transforma o sofrimento particular em uma generalização e em uma abstração: o sofrimento de um é generalizado e passa a representar o sofrimento de uma classe ou multidão.

Segundo a autora, Robespierre usou toda a sua eloquência para defender que a piedade era a maior virtude revolucionária. Para ele, a pobreza consistia no maior problema da França, nesse contexto, a piedade era a virtude daquele que se condoía pelos pobres e que buscava sanar o sofrimento causado pela miséria.

A piedade, graças à sua generalidade, é ilimitada, e pode ser capaz até mesmo de gerar crueldade. De acordo com Arendt, os piedosos afastam-se da realidade particular ao procederem à generalização: despersonificam o sofrimento na medida em que o suplício do próximo é encarado como um caso dentre muitos. O sofrimento gerado pela pobreza é aquele que torna mais plausível a despersonificação: as necessidades vitais são as mesmas para todos da espécie humana, nesse sentido, ao olhar para os pobres pode-se desprezar facilmente a singularidade de cada um e tomá-los como uma massa homogênea que precisa apenas de pão.

Esta despersonificação do sofrimento e o afastamento da realidade particular que a piedade opera podem gerar a noção de que é aceitável sacrificar alguns em nome do sofrimento de muitos. Dito de outra forma, a piedade pode produzir a concepção de que, para acabar com a infelicidade dos miseráveis, deve-se fazer de tudo: passar por cima das leis e de pessoas em favor do bem maior. Para ilustrar isso, Arendt cita uma frase contida na petição redigida por uma Comuna de Paris e enviada à Convenção Nacional: "Por piedade, por amor à humanidade, sejam desumanos" (Sobre a Revolução, p. 128).

Segundo a autora, a solidariedade é a alternativa à piedade. A solidariedade também participa de uma operação da razão, por isso, possui uma generalidade e consegue abranger multidões, classes e povos. Mas, ao contrário da piedade, ela não está vinculada ao sofrimento, nem à compaixão, a solidariedade é desapaixonada. Trata-se de um princípio compartilhado com os oprimidos e explorados de que ninguém deveria estar sob o jugo da 
necessidade e sob o domínio de outrem. Nesse sentido, a solidariedade mantém um compromisso coma ideia de dignidade humana, não com uma paixão. ${ }^{113}$

Para Arendt, na Revolução Francesa, a piedade levou à crueldade e à violência desenfreada quando ela se tornou a principal virtude política e os cidadãos tiveram que provar publicamente que levavam a compaixão em seus corações e que suas intenções eram guiadas pela piedade. De acordo com a autora, graças à natureza da ação política, as paixões e intenções do agente não podem ser comprovadas. Em suas palavras: "Sem dúvida todo ato tem sua motivação, além de um objetivo e de um princípio; o ato em si, porém, mesmo que proclame seu objetivo e evidencie seu princípio, não revela a motivação interna do agente." (Sobre a Revolução, p. 138).

Como já foi mencionado, a atividade política envolve uma pluralidade de pessoas e, por isso, não pode ser realizada em nome de uma motivação ou paixão individual, ela só pode estar ligada a um princípio que transcenda a subjetividade de cada um e que é compartilhado pelo agente e pelo público.

Na perspectiva arendtiana, o público é testemunha somente da ação e das palavras do agente, não de suas intenções ou paixões. Portanto, nenhum agente pode provar em uma cena pública o que ele carrega no coração e na mente. $\mathrm{O}$ agente pode apenas representar um princípio, no sentido de falar em nome de algo, como justiça, liberdade, igualdade etc. Como foi mencionado no capítulo anterior, em Sobre a Revolução, a autora acrescenta à analogia entre ação política e teatro (que foi tratada em Entre o Passado e o Futuro) o termo persona. ${ }^{114}$ Originalmente o termo indicava a máscara que substitui o rosto do ator e demostra o papel que deveria ser representado. Mais tarde, o termo persona passou para a linguagem jurídica e política e passou a significar então que os cidadãos romanos tinham um papel e uma personalidade pública diferente de suas tarefas e modo de ser na vida privada.

Nesse sentido, o espaço público, para a autora, consiste no lugar da aparência, onde o que conta não são as paixões, ou intenções, ou mesmo a moral, mas o modo pelo qual o agente aparece, qual princípio ele representa. Nesse ponto, Arendt concorda com

\footnotetext{
${ }^{113}$ Ver em Sobre a Revolução, p. 127.

${ }^{114}$ Ver em Sobre a Revolução, p. 148.
} 
Maquiavel em que na política a moralidade e os valores privados não devem ser aplicados, a esfera pública possui outros critérios e valores. ${ }^{115}$

Levando em conta que o espaço público consiste em um lugar onde as paixões e as intenções só podem ser representadas, elas consistem em meras aparências: é impossível para qualquer cidadão provar que sente piedade pelos pobres ou que possui alguma motivação contra a miséria. Por isso, ninguém poderia ter certeza se os homens na Revolução Francesa verdadeiramente carregavam em seus corações a compaixão e cultivavam a piedade. Sem esta certeza, naturalmente, aqueles que entendiam que a piedade deveria ser comprovada publicamente passaram a desconfiar de seus concidadãos. Nas palavras da autora: "Robespierre e seu seguidores, depois de igualarem a virtude às qualidades do coração, viam intrigas e calúnias, traição e hipocrisia por todas as partes" (Sobre Revolução, p. 136).

A autora esclarece que "hipócrita" é uma palavra de origem grega e seu significado original é "ator de teatro". Uma vez que a ação, de acordo com Arendt, tem características semelhantes às artes performáticas, todo homem na cena pública pode ser considerado hipócrita.

No entanto, a hipocrisia apareceu na Revolução Francesa primeiramente como característica da corte de Versalhes. A hipocrisia da corte estava ligada ao desprezo que a aristocracia desenvolveu pela honra ou por qualquer responsabilidade política e ainda estava relacionada com a desconsideração pelos demais estamentos da sociedade na França. Resumidamente, a corte de Versalhes se preocupava com seu bem estar e era completamente insensível à situação do povo francês.

Nesse sentido, a hipocrisia significava primeiramente o rompimento com o juramento da monarquia e da corte de seguir certos costumes e promessas que prescreviam cuidados com o mundo e com o povo. Na medida em que a hipocrisia da corte foi entendida como negligência com o povo, foi possível acreditar, assim como Robespierre, que a piedade como virtude pública faria com que os homens abnegassem suas vontades particulares e agissem em favor do bem estar do povo. Nesta concepção, quem possui esta virtude auxilia o governo revolucionário e quem não a possui age contra a revolução. $\mathrm{O}$ desenvolvimento desta argumentação leva à conclusão de que, para acelerar o progresso

${ }^{115}$ Conferir em Entre o Passado e o Futuro, p. 182. 
revolucionário, era preciso identificar e caçar aqueles que não eram guiados pela compaixão e pela piedade.

Uma vez que ninguém pode comprovar que é piedoso, um cidadão pode apenas falar em nome da piedade, isto é, representá-la. Usar a máscara da piedade no espaço político não foi entendido com um meio de falar em prol dos miseráveis, ao contrário, foi entendido como um recurso para a fraude. A desconfiança generalizada, somada à crueldade que a piedade pode gerar, conduziu a uma violência progressiva na caçada aos hipócritas. Dito em outras palavras, uma vez que a hipocrisia foi considerada uma força contrarrevolucionária e os piedosos estavam dispostos a sacrificar qualquer coisa e qualquer um por uma causa maior, a violência e o julgamento sumário passaram a ser vistos como melhor recurso. Além disso, como ninguém pode comprovar que sente compaixão, qualquer um poderia ser acusado e condenado de ser hipócrita e o número de acusados não tinha fim.

A este respeito, a autora assevera que: "A revolução desmascara seus filhos antes de passar a devorá-los" (Sobre a Revolução, p. 139). Ainda, afirma: "Foi a guerra à hipocrisia que transformou a ditadura de Robespierre no Reinado do Terror" (Sobre a Revolução, p. 140).

Mais uma vez, é possível notar que o uso da violência não foi gerado automaticamente pela emergência da questão social, mas foi mediado por concepções e ideias políticas, tais como virtude, centralização, vontade geral.

Na perspectiva arendtiana, embora a violência possa auxiliar na revolução no que diz respeito à destruição do antigo governo e à libertação da dominação, para Robespierre, a violência tinha um papel mais central. A autora não recrimina a violência usada no início da revolução, por exemplo, aquela empregada na Queda da Bastilha. Em sua perspectiva, esta violência foi a reação a uma série de descumprimentos de compromissos e juramentos políticos que Luís XVI e a corte de Versalhes deveriam manter para continuar a governar. ${ }^{116}$ No entanto, para a Arendt, a raiva contra o absolutismo e a violência foram direcionadas, mais tarde, às organizações populares e a membros da Assembleia Nacional por meio da piedade e da caça aos hipócritas. Nesse contexto, qualquer um comprometido com questões constitucionais e republicanas sem habilidade nas tarefas econômico-

\footnotetext{
${ }^{116}$ Conferir em Sobre e Revolução p. 146 e 147.
} 
administrativas e sem capacidade de lidar com problemas sociais passou a ser taxado de hipócrita, corrupto ou perpetuador da miséria. "Foi a luta dessas duas raivas, a raiva do infortúnio nu lançando-se contra a raiva da corrupção desmascarada, que provocou a 'reação contínua' de 'violência progressiva'" (Sobre a Revolução, p. 153). Robespierre, para Arendt, foi quem dirigiu a força e a raiva dos miseráveis contra as organizações políticas recém-formadas pela revolução, foi quem glorificou o uso da violência.

Conforme a autora, Robespierre relacionava fundação com o uso de meios violentos e, quando se tornou líder do governo revolucionário, ele passou a usar da violência para manter a revolução e resolver a questão da pobreza.

Bignotto, no artigo dedicado ao republicanismo francês, parece concordar com Arendt no que se refere ao fato de Robespierre relacionar fundação, virtude e violência. Para o autor, este revolucionário apresentou uma concepção republicana fortemente marcada pelo comportamento virtuoso e pela defesa da unidade da nação. Robespierre considerava, em 1793, que os inimigos do povo dificultavam a fundação da república e, por isso, antes de agir para constituir leis e instituições era preciso perseguir aqueles que colocavam a revolução em risco. ${ }^{117}$ Ele afirmava que o homem virtuoso conhece as leis que proporcionam a liberdade: elas estão gravadas em seu coração. Dessa forma, a preocupação com a criação de normas e instituições era secundária, uma vez que o vício fosse combatido e a virtude fosse dominante, as leis republicanas fatalmente seriam seguidas. ${ }^{118}$ Em sua perspectiva, o uso da violência contra os inimigos do povo era o instrumento por excelência para acabar com os homens torpes e fundar a república. Nas palavras de Robespierre: "Dome pelo terror os inimigos da liberdade e vocês estarão certos como fundadores da República” (Bignotto, “A Matriz Francesa”, p. 216).

Ainda, Bignotto destaca outra frase do revolucionário jacobino que reforça esta vinculação entre fundação, violência e virtude: "O terror nada mais é do que a justiça pronta, severa, inflexível; ele é, pois, uma emanação da virtude” (“A Matriz Francesa”, p. 217).

\footnotetext{
${ }^{117}$ Robespierre declarou que o objetivo do governo revolucionário era fundar a república, já o objetivo do governo constitucional era conservá-la. Ver em Bignotto, “A Matriz Francesa”, p. 212.

${ }_{118}$ Conferir em "A Matriz Francesa", p. 214.
} 
De acordo com Arendt, o recurso à violência pode ser explicado em parte pela incapacidade de se conferir um desfecho à revolução por meio de uma Constituição estável. Depois do malogro da Constituição girondina, Robespierre não ratificou o texto constitucional jacobino e defendeu a revolução permanente. Com isso, a vida institucional da República francesa não foi estabilizada. Vale lembrar que para Arendt, uma das características da ação é a imprevisibilidade. Agir envolve uma pluralidade de agentes, quem inicia um ato não consegue controlar o seu desenrolar, pois os demais, os quais se unem a ele para conduzir o que foi começado, podem continuar um estado de coisas ou introduzir algo novo. Ainda, não é possível saber até onde e quando se estenderá a cadeia de acontecimentos que o agir iniciou. Para a autora, o preço da liberdade de ação é a imprevisibilidade dos assuntos humanos e o preço da pluralidade é que ninguém pode ser o senhor da ação nem prever todas as suas consequências. ${ }^{119}$

A única solução política para a imprevisibilidade da ação é a promessa, um acordo mútuo que estabelece limites à ação. A faculdade de prometer e cumprir promessas cria certas ilhas de segurança, marcos de confiabilidade ao futuro que é um oceano de incertezas. ${ }^{120}$ Além disso, a promessa é aquilo que mantém unidas as pessoas mesmo quando não estão no espaço público, é o que confere permanência aos assuntos humanos. Nesta perspectiva, prometer significa compartilhar e preservar limites e princípios que interessam aqueles envolvidos no compromisso mútuo. Em outras palavras, a promessa, além de estabelecer limites, também resguarda algo que se situa entre as pessoas, que as relaciona e as mantém unidas. Sem a faculdade de prometer, a relação pública entre os homens não pode ser duradoura.

$\mathrm{Na}$ medida em que a Constituição registra o acordo entre os membros da comunidade política, um de seus efeitos consiste em estabelecer limites para o novo corpo político. O fato de nenhuma Constituição ter sido duradoura na Revolução Francesa implicou a falta de limites para a ação. Na metáfora arendtiana, nesse contexto, os homens se encontravam num oceano de incertezas, sem nenhum marco onde pudessem vislumbrar uma fronteira dentro da qual agir.

\footnotetext{
${ }^{119}$ Sobre a imprevisibilidade da ação, conferir em $A$ Condição Humana, p. 295.

${ }^{120}$ Conferir em $A$ Condição Humana, p. 295 e 305.
} 
Robespierre, no decurso da revolução, pareceu tentar escapar da imprevisibilidade da ação e procurou uma atividade que garantisse que os objetivos definidos pelo iniciador do ato fossem atingidos. Nos termos arendtianos, ele procurou agir nos moldes da fabricação. Para a autora, esta atividade é definida pela categoria de meios e fins: o fabricante define os instrumentos e a forma de fazer o objeto a partir da ideia ou do modelo do que se quer produzir. Aplicada à vida pública, a fabricação requer que alguém defina um plano e faça com que os demais o executem.

De acordo com Arendt, Robespierre encontrou um plano para a Revolução Francesa nos livros de Maquiavel. ${ }^{121}$ Ela concorda em que Maquiavel pode ser considerado o teórico pai das revoluções. Um tipo de revolucionário "avant le lettre" em razão de sua preocupação com a durabilidade e a estabilidade do corpo político, por reavivar as instituições romanas e por tratar da questão da fundação. Além disso, para Arendt, Maquiavel consiste no primeiro pensador a considerar um domínio público puramente secular. Robespierre, ao ler o pensamento maquiaveliano como um plano para a revolução, adotou a atividade de fabricar na esfera pública. Na tentativa de evitar a imprevisibilidade própria da atividade política e garantir que o plano da revolução fosse executado, foram abandonados o debate público e a persuasão. Ora, se o plano fora feito por Maquiavel, a deliberação pública não seria necessária, não havia o que ser decidido sobre os rumos da França, somente era preciso executar este plano. Para isso, um só homem deveria ordenar a república enquanto os outros deveriam simplesmente seguir ordens. Nesse sentido, segundo Arendt, ao adotar esta noção de fundação, Robespierre passou a agir contra a liberdade e igualdade de falar e atuar nos diversos órgãos populares inaugurados no início da Revolução Francesa.

Além disso, a autora indica que a noção de uma fundação absoluta surgiu dessa equiparação entre o ato de fundar e o fazer. A noção de fabricação permite a concepção de uma ruptura absoluta com o passado e a criação constitucional exnihilo: o fazer produz algo conforme uma ideia abstrata, sem se relacionar com o contexto histórico. Para Arendt, a ruptura com a ordem política, institucional e legal é sempre relativa, pois a ação não se

${ }^{121}$ Sobre a Revolução, p. 66-68. 
dá em um vácuo temporal ou fora de um contexto político. O evento espontâneo perde sua singularidade quando é arrancado do tempo, de seu pano de fundo histórico e político. ${ }^{122}$

De acordo com a autora, Maquiavel e Robespierre usaram a mesma linguagem: viam na fundação a ação política central e ambos defendiam a necessidade de um ato extraordinário, violento, para fundar ou reformar um corpo político. Além disso, entendiam que seria preciso estar só para fundar ou reformar uma república e que, para esse fim supremo, todos os meios eram justificados. Nas palavras de Arendt:

"Compreendiam o ato de fundar inteiramente à imagem do fazer; a questão para eles era, literalmente 'fazer' uma Itália unificada ou uma república francesa, e sua justificação da violência guiava-se pelo seguinte argumento (...): não se pode fazer uma mesa sem abater árvores, nem fazer uma omeleta sem quebrar ovos; não é possível fazer uma república sem matar gente" (Entre o passado e $o$ futuro, p. 184).

A interpretação de Maquiavel feita por Robespierre retira do autor somente os elementos que corroboram a formação do Estado nacional, como a figura do fundador que pode recorrer a atos extraordinários e a noção de um corpo político secularizado. Entretanto, outras concepções do autor hostis às noções de nação e vontade geral são negligenciadas, tal como a teoria dos humores, a qual afirma que todo corpo político é dividido entre o desejo dos grandes de dominar e desejo do povo de não ser dominado e que tal conflito entre estas partes deve ser expresso em instituições e resultar em ordenamentos.

Assim, Robespierre, ao se apoiar em parte do pensamento de Maquiavel, não entendeu a violência como um problema que poderia levar a revolução ao fracasso, ao contrário, ao defender que a fundação engendrava atos extraordinários e a centralização de poder e da decisão em uma só pessoa, a violência se tornou o melhor recurso, e talvez o único, para atingir a finalidade da revolução. E quando o objetivo principal da revolução deixou de ser a liberdade e se tornou a necessidade, isto é, quando as questões políticas foram esquecidas em favor das sociais, esta concepção de fundação foi desvinculada da ordenação de leis e instituições e se manteve restrita à execução de atos extraordinários. Para ilustrar esta mudança da política para o social, a autora menciona duas frases do líder jacobino: "Tudo que é necessário para manter a vida deve ser um bem comum [...]" (Sobre

\footnotetext{
122 Sobre o problema do início exnihilo conferir em Kalyvas, Democracy and the Politics of the Extraordinary, p. 223-226.
} 
a Revolução, p. 94). "A república? A monarquia? Conheço apenas a questão social” (Sobre a Revolução, p. 89).

Para Arendt, a definição de fundação como uso de medidas extraordinárias pode levar ao fim do espaço político no momento em que uma reforma urgente aparece como necessária. Na interpretação da autora, foi o que ocorreu na França. Como já foi mencionado, a multidão que apareceu no espaço público durante a Revolução Francesa estava sob o jugo da necessidade e, além de lutar pela igualdade de direitos e de participação política, reivindicava a resolução do problema da pobreza. A concepção de fundação como fabricação nesse contexto de miséria fez Robespierre concluir que o longo processo de deliberação característico da ação política era inadequado enquanto que a centralização do poder e a rápida execução de medidas extraordinárias eram apropriadas. Assim, as comunas, clubes e sociedades populares - elogiados pelo líder jacobino no início da Revolução - tornaram-se um empecilho ao governo revolucionário e passaram a ser perseguidos. ${ }^{123}$ Aqui, mais uma vez, fica claro que não foi somente a questão social que levou a revolução à ruína, mas especialmente um elemento político de primeira importância: a concepção de fundação como fazer promoveu a defesa da violência e o uso da força.

De acordo com a autora, violência é diferente de terror. $\mathrm{O}$ terror se estabelece onde a violência não é limitada e destrói a possibilidade dos homens agirem em concerto e gerarem algum poder. Neste caso, a violência se transforma em um meio sem fim, isto é, não tem mais limites. $\mathrm{O}$ ápice do terror ocorre quando o executante de ontem é a vítima de hoje. ${ }^{124}$ Embora o verdadeiro regime movido pelo princípio do terror tenha sido o totalitarismo, com a caça aos hipócritas na Revolução Francesa, a violência se tornou ilimitada, não poupava nada nem ninguém, e assim a revolução passou a devorar seus próprios filhos.

Segundo Arendt, este curso da Revolução Francesa - o paulatino desvio da constituição de um corpo político baseado na liberdade para a questão da necessidade, a centralização do poder e a progressão da violência - foi entendido nos séculos XIX e XX pelos revolucionários profissionais como o caminho necessário de toda revolução. Como

\footnotetext{
${ }^{123}$ Sobre a Revolução, p. 307.

${ }^{124}$ Sobre a violência, p. 43-44.
} 
foi tratado no capítulo anterior, a interpretação das revoluções por meio da filosofia da história e do conceito moderno de história organiza os fatos e feitos dentro de uma noção de processo e daí extrai o sentido da história e organiza a forma de agir. Nesta perspectiva, a progressão da centralização e do uso da violência na Revolução Francesa foram interpretados como o sentido da revolução e com isso os revolucionários profissionais passaram a atuar nas revoluções posteriores para produzir este mesmo percurso.

Nos termos da autora, "pois sempre que as revoluções em nosso século apareciam no palco da política, eram vistas como imagem do curso da Revolução Francesa, enquadradas em conceitos cunhados por espectadores e entendidas em termos de necessidade histórica" (Sobre a Revolução, p. 88). A Revolução de Outubro na Rússia ilustra este esforço de modelar o curso da ação conforme os acontecimentos passados. Os órgãos políticos populares, os sovietes, foram desarticulados em nome da centralização e da necessidade de medidas rápidas e extraordinárias. A violência se tornou o melhor recurso para completar o objetivo revolucionário, em outras palavras, a caça àqueles que retardavam o avanço da revolução se tornou mais importante do que a tarefa de fundar um novo corpo político e de garantir espaço de participação ampliada nos assuntos comuns.

"O problema é sempre o mesmo: os que frequentaram a escola da revolução aprenderam e ficaram conhecendo de antemão qual curso devem tomar as revoluções. O que eles imitaram foi o curso dos acontecimentos, não os homens da revolução" (Sobre a Revolução, p. 91).

Na perspectiva da autora, o malogro da Revolução Russa se deu em grande parte em razão da adoção do curso da Revolução Francesa como modelo e das concepções dos revolucionários profissionais que compreendiam que tanto os eventos revolucionários como a história possuem um caminho e um movimento determinado e identificável.

Nesse sentido, para Arendt, o debate acerca da herança da Revolução Francesa é fundamental. A autora combate a interpretação deste evento revolucionário nos séculos XIX e início do XX e procura enfatizar os grandes feitos dos franceses nas comunas, assembleias primárias, clubes e sociedades populares, busca reavivar as concepções de liberdade e república que surgiram no início deste evento. Além disso, Arendt também procura tratar dos erros e problemas deste evento. No caso da Revolução Francesa, como vimos, isso envolve discutir os conceitos que guiaram as ações dos homens engajados neste evento, tais como soberania, nação, vontade geral e fundação. 


\subsection{As Declarações na Revolução Norte-Americana e na Revolução Francesa.}

Arendt afirma que um dos desafios enfrentados por aqueles que fundam um novo corpo político sem adotar uma forma constitucional preexistente consiste em dotar a Constituição inédita de autoridade. Em outras palavras, o problema de instituir um novo corpo político reside em conferir durabilidade a ele, em fazer com que a Constituição seja respeitada e sustentada pelo povo e pelas gerações futuras.

$\mathrm{Na}$ Revolução Francesa, que lutava contra um regime em que os privilégios de certos estamentos eram a base do direito e em que o arbítrio dos reis governava, o desafio era fundar um corpo político baseado na igualdade de direito e colocar a lei acima dos homens. Para tanto, os revolucionários procuraram uma fonte de autoridade preexistente à nova Constituição. Segundo Arendt, na França, eles adotaram a categoria de nação para legitimar a fundação do novo corpo político: a nação institui por sua vontade soberana um governo civil.

De acordo com a autora, os homens da Revolução Francesa entendiam ter encontrado uma fonte segura de autoridade uma vez que a nação, por pertencer ao estado de natureza, está fora de questionamento. Contudo, a vontade da nação, por ser anterior e externa ao espaço político, não foi entendida como algo que pode ser limitado ou restrito por normas e instituições políticas. Dessa forma, não foi estabelecido um limite ou marco para a ação e para os atos de governo.

É importante destacar, no entanto, que, apesar das críticas de Arendt à concepção de nação, na Revolução Francesa, a libertação foi muito mais radical do que na Revolução Americana. Enquanto na América se declararam direitos para os homens livres que viviam nas treze colônias, na França, a liberdade e a igualdade foram entendidas como direito de todos os homens da terra, mesmo aqueles que viviam sob o jugo da escravidão e da dominação. Este foi um dos motivos que fez com que o evento revolucionário francês tivesse muito mais impacto político do que o evento revolucionário no Novo Mundo. Arendt mostra que a Declaração Universal dos Direitos do Homem e do Cidadão, por um lado, ao relacionar liberdade e nascimento, cidadania e nação, divulgou a concepção de que todos os homens devem ter direitos e estar libertos da dominação, por outro lado, fez surgir uma relação entre ação e natureza que dificultou o estabelecimento de limites na vida 
política. No decorrer do evento revolucionário na França, o governo acabou se tornando tão ou mais arbitrário do que o absolutismo, afinal, um governo baseado na vontade da nação não é menos inconstante e ilimitado do que um governo baseado na vontade do rei.

Já os revolucionários norte-americanos não procuraram uma autoridade preexistente e externa à política e, por isso, o novo corpo político fundado foi dotado de limites e marcos bem estabelecidos. Para Arendt, os homens engajados nesta revolução já haviam aprendido com os primeiros colonos do Novo Mundo a força dos pactos e promessas. Os pactos mútuos têm a potência de estabelecer tanto interesses comuns quanto limites. O interesse comum é algo que se situa entre as pessoas envolvidas no pacto, ele as relaciona e as mantém unidas enquanto o compromisso em agir em prol deste interesse perdurar. A faculdade de fazer e cumprir promessas estabelece também limites para a ação humana quando pessoas escolhem marcos e fronteiras dentro dos quais podem agir no presente e no futuro.

O objetivo do pacto e da promessa que se estabelece quando uma comunidade política é formada consiste em encontrar um princípio de justiça compartilhado e em estabelecer marcos e fronteiras para as instituições e para as ações condizentes com este princípio. Na perspectiva de Arendt, a Declaração de Independência foi o momento em que os homens no Novo Mundo se associaram em torno de um princípio de justiça comum, a saber, "o direito à vida, à liberdade e à procura da felicidade". No momento em que redigiram esta declaração, eles se comprometeram a criar um novo corpo político que garantisse esses direitos.

Vimos acima que na América do Norte foi fundado um corpo político baseado na representação de opiniões plurais no Senado, na associação entre a União e os Estados. Além disso, foi criada uma instituição, a Suprema Corte, com o papel de resguardar a Carta Constitucional. Nesse contexto, os direitos civis, individuais e o direito de buscar a felicidade em sentido privado foram garantidos. Já o direito à liberdade e à felicidade pública não foram amplamente estabelecidos: o sistema representativo garantiu direito de voto aos homens livres e reservou o direto de participar do governo aos eleitos pelo povo.

$\mathrm{Na}$ Revolução Francesa, o princípio de justiça compartilhado foi enunciado em seu início: liberdade, igualdade e fraternidade. Contudo, como nenhuma Constituição foi duradoura, nenhum corpo político e conjunto de leis puderam garantir este princípio por 
muito tempo. De acordo com Tocqueville, o compromisso com a igualdade de condições foi predominante na França. No decorrer da revolução, o apreço pela liberdade e pela fraternidade foi embotado. Para Arendt, além do gosto pela liberdade ter sido fugaz, as concepções políticas de vontade da nação e soberania, ao alocarem a autoridade no estado de natureza, trouxeram empecilhos para a instituição de um novo corpo político estável.

Honig, no artigo "Declarations of Independence: Arendt and Derrida on the Problem of Founding a Republic", critica esta comparação entre a Revolução Francesa e a Revolução Americana. De acordo com ela, os revolucionários no Novo Mundo também procuraram escapar do desafio de fundar um novo corpo político recorrendo a um absoluto que estava fora de questionamento. O preâmbulo da Declaração de Independência apresenta dois apelos para uma fonte transcendente de autoridade: a natureza divina e as verdades auto-evidentes.

Segundo Honig, uma vez que a secularização teve como efeito a falta de instrumentos de legitimação das formas constitucionais, a fundação e a autoridade se tornaram os problemas políticos centrais da Modernidade. Nesse sentido, os homens da revolução na América procuraram um início no passado remoto para derivar a autoridade e estabilidade do novo corpo político de uma república já dada - Roma. Esta reafirmação da Antiguidade apontaria para uma falta de confiança por parte dos revolucionários em suas próprias ações. Isso os teria levado a fundamentar a esfera política em um absoluto. ${ }^{125}$

A passagem da Declaração de Independência "Nós consideramos estas verdades como evidentes por si mesmas, que todos os homens são criados iguais, dotados pelo Criador de certos direitos inalienáveis, que entre estes estão a vida, a liberdade e a procura da felicidade" não é interpretada pela comentadora somente como uma expressão de um acordo entre os homens da revolução acerca de direitos imprescindíveis, mas também como apelo aos céus e à razão.

Nesse sentido, esta autora afirma que há uma ambiguidade nesta declaração. Por um lado, a expressão "nós consideramos" (we hold) remete a uma promessa mútua que estabelece a comunidade política e cria poder, por outro lado, o recurso ao Criador e a verdades auto-evidentes abre espaço para uma autoridade autoritária: a razão é compelida

\footnotetext{
${ }^{125}$ Conferir em "Declarations of Independence: Arendt and Derrida on the Problem of Founding a Republic", p. 99 e 100.
} 
pela verdade e os homens devem obediência a Deus. Ao redigir a Declaração de Independência, Jefferson tentou conferir às leis da comunidade a mesma força coercitiva das leis da natureza. Nesta interpretação, o conceito tradicional de lei como mandamento não havia sido completamente superado.

Conforme Honig, Arendt não tratou suficientemente dessa ambiguidade, pois celebrou a Declaração de Independência como um ato discursivo puramente performativo e desprezou os aspectos afirmativos e declaratórios deste documento. ${ }^{126}$ Por isso, Arendt teria produzido uma fábula da fundação na qual usou a Declaração de Independência para preencher a lacuna na sua teoria do ato fundador. ${ }^{127}$

Em nossa interpretação, Honig, ao conferir centralidade à Declaração de Independência, não avalia corretamente o estabelecimento da autoridade no Novo Mundo, pois negligencia os anos de debate constitucional. O pacto que faz nascer a comunidade política começa a surgir com a escolha do princípio de justiça enunciado nesta Declaração, mas as leis decorrentes dela e as instituições responsáveis por resguardá-lo são instituídas com a Carta Constitucional. Para Arendt, a Declaração de Independência é o marco do início da Revolução Americana, enquanto que a promulgação da Constituição consiste em sua finalidade e término. ${ }^{128}$

Segundo Arendt, a Declaração de Independência representa o auge da resistência no Novo Mundo. Com este documento, a monarquia foi expressamente rejeitada e as condições para a ação fundadora foram abertas: deu-se início ao debate sobre a constituição de um novo corpo político. ${ }^{129}$ Para a autora, esta Declaração foi a forma da ação revolucionária aparecer em palavras. ${ }^{130}$

Starling corrobora a interpretação arendtiana ao explicar as duas funções das declarações na tradição anglo-americana. Segundo a historiadora, uma declaração tinha o papel de anunciar uma nova política e procurar apoio para sua implementação. $\mathrm{O}$

\footnotetext{
${ }^{126}$ Conferir em "Declarations of Independence: Arendt and Derrida on the Problem of Founding a Republic", p. 101.

${ }^{127}$ Ver em "Declarations of Independence: Arendt and Derrida on the Problem of Founding a Republic", p. 107.

${ }^{128} \mathrm{O}$ trecho a seguir mostra claramente o início e o término da Revolução Norte-Americana para Arendt: "[...] os homens da Revolução Americana se mantiveram homens de ação do começo ao fim, da Declaração de Independência à montagem da Constituição." (Sobre a Revolução, p. 135).

${ }^{129}$ Ver em Sobre a Revolução, p. 175.

${ }^{130}$ Conferir em Sobre a Revolução, p. 176.
} 
preâmbulo da Declaração de Independência dos Estados Unidos anuncia a nova política ao apresentar um pacto que pretende assegurar para o futuro um conjunto de princípios de justiça que balizaria as novas leis e instituições do corpo político que seria fundado. Tais princípios - direito à vida, à liberdade e à felicidade - já haviam sido relacionados com a fundação de um governo reto pelos autores do republicanismo radical inglês no século XVII. Por isso, no contexto revolucionário norte-americano, estes princípios dispensavam a argumentação e persuasão, eram considerados como evidentes por si mesmos, pois retomavam a tradição republicana inglesa. ${ }^{131}$

De acordo com Starling, a Declaração na América procurava conquistar apoio dos colonos ainda não engajados com a independência e o apoio de outros países ao listar vinte e oito agravos que denunciavam o abuso de autoridade da Coroa Inglesa. ${ }^{132}$

Levando isso em conta, podemos afirmar que este documento visava a abolir a autoridade e o poder da Coroa e do Parlamento inglês na América do Norte e a anunciar que os revolucionários, a partir de então, debateriam e agiriam para criar uma nova autoridade e um novo poder.

Arendt indica que, no início do evento revolucionário no Novo Mundo, os homens, ao mesmo tempo em que revelaram seu pacto mútuo, recorreram a Deus e à razão como fonte transcendente de autoridade. ${ }^{133}$ No entanto, no documento final produzido por esta revolução - a Carta Constitucional -, não foi mencionada uma fonte de autoridade absoluta e transcendente. ${ }^{134}$

Honig interpreta este silêncio no texto constitucional com relação a um absoluto como a evidência de que a Declaração de Independência seria o documento que garante a autoridade do novo corpo político. ${ }^{135}$

De forma distinta, entendemos que a autoridade precisou de tempo para ser desenvolvida e, por isso, não se assenta somente na Declaração de Independência, mas especialmente na Constituição. No preâmbulo da Carta Constitucional, os agentes envolvidos no pacto e que geraram o novo poder se apresentam no trecho "nós, o povo dos

\footnotetext{
${ }^{131}$ Conferir em "A Matriz Norte-Americana”, p. 265.

${ }^{132}$ Ver em "A Matriz Norte-Americana", p. 261 e 262.

${ }^{133}$ Conferir em Sobre a Revolução, p. 248

${ }^{134}$ Ver em Sobre a Revolução, p. 250.

${ }^{135}$ Ver em "Declarations of Independence: Arendt and Derrida on the Problem of Founding a Republic", p. 106.
} 
Estados Unidos". A promessa presente na Declaração de Independência é reafirmada e está expressa na seguinte frase: "garantir para nós e para os nossos descendentes os benefícios da Liberdade, promulgamos e estabelecemos esta Constituição para os Estados Unidos da América”. Em nossa perspectiva, ao fim e ao cabo da revolução, a concepção de uma autoridade absoluta e transcendente foi superada, uma vez que Constituição não faz referência a elementos extra-políticos.

Do mesmo modo, entendemos que, na Revolução Francesa, a relação entre autoridade, soberania e vontade da nação tomou forma com o tempo no debate constitucional francês. Vimos que Rousseau foi citado por vários atores e grupos diferentes durante a o debate constitucional a partir de 1789. A interpretação do significado e da institucionalização de seu conceito de soberania foi alvo de disputa política na Revolução Francesa. Para Baker, Sieyès foi determinante nesta disputa. ${ }^{136}$ Segundo o historiador, em Rousseau, a soberania estava ligada à vontade geral, ao povo e ao contrato social; já com Sieyès, soberania foi relacionada com nação, nesse sentido, dizia respeito a indivíduos que não estão vinculados por laços sociais ou pactos, mas sim pelo nascimento comum. ${ }^{137}$ Além disso, no pensamento rousseauniano, a vontade geral não pode ser representada. De forma distinta, Sieyès defendeu, no curso do debate constitucional, que a vontade da nação se expressa na Assembleia Nacional. Para este revolucionário, as assembleias primárias, clubes e sociedades populares acabavam por expressar vontades particulares ou facciosas: "[...] não havia vontade comum fora da Assembleia Nacional [...]” (Dicionário Crítico da Revolução Francesa, p. 889).

Arendt, assim como Baker, entende que as concepções de Sieyès, ao ganharem apoio de outros atores políticos, contribuíram para a centralização de decisões no decurso da Revolução Francesa. Ela aponta ainda que a noção de vontade da nação foi relacionada com a virtude da piedade de Robespierre e com a caça aos hipócritas. Dessa forma, a centralização foi reforçada pela perseguição de dissidentes.

Pode-se concluir com isso que a autora não fundamenta sua análise sobre as revoluções em apenas uma concepção ou em um documento, mas procura compreender as mudanças de concepções e opiniões por meio de atores distintos e diversos textos.

\footnotetext{
${ }^{136}$ Baker discute isso no verbete intitulado "Soberania" do Dicionário Crítico da Revolução Francesa.

${ }^{137}$ Conferir em Dicionário Crítico da Revolução Francesa, p. 887.
} 


\subsection{História dos conceitos e as narrativas das revoluções em Arendt}

Vimos acima que Arendt articula a história de conceitos particulares, como autoridade, ação, liberdade, soberania, vontade, entre outros, para mostrar o horizonte de compreensão dos revolucionários na América do Norte e na França. De acordo com a autora, a compreensão preliminar é um senso comum que engendra uma avaliação acerca da situação dos negócios públicos e que pode veicular princípios de ações. A partir disso é possível alcançar o significado de um evento, uma vez que a compreensão dos agentes revela suas perspectivas sobre o mundo e o sentido de sua ação. ${ }^{138}$ Levando isto em conta, os conceitos e as ideias veiculados pelas principais figuras das revoluções nos dois lados do Atlântico revelam a compreensão que os revolucionários tinham de seu tempo e quais princípios foram escolhidos para guiar seus atos.

A história intelectual, isto é, a formulação de narrativas sobre eventos passados principalmente por meio das ideias e conceitos de pensadores e atores políticos, de acordo com Palti, consiste em uma tradição do pensamento alemão. Tanto a história das ideias quanto a história dos conceitos foram inauguradas e desenvolvidas por pensadores alemães desde o final século XIX. ${ }^{139}$

Ainda conforme este autor, a história dos conceitos não trata apenas de um conceito específico, visa antes à articulação entre conceitos que formam uma rede semântica. Tal rede indica um universo simbólico que é capaz de explicar uma experiência vivida, mas também é um elemento ativo no desenrolar de eventos. Nesta perspectiva, os conceitos fornecem ferramentas para que os agentes entendam o sentido de suas ações. A história conceitual, dessa forma, revela mais do que os significados e usos de determinados

\footnotetext{
${ }^{138}$ Sobre compreensão preliminar e completa, ver em Compreender, formação, exílio e totalitarismo, p. 333 334. Também fizemos uma interpretação mais detalhada destes conceitos no primeiro capítulo.

${ }^{139}$ De acordo com o autor, a história das ideias, apesar de tratar das mudanças de significado das ideias através do tempo, procura um núcleo conceitual que se mantém intacto. E, por isso, remete de certa forma à ontologia das ideias. Já, para a história dos conceitos, um conceito é algo rico de significados, que se desenvolve historicamente e é capaz de ultrapassar seu contexto original. Nesse sentido, a história conceitual se aproxima da fenomenologia. Conferir em Palti, "Form Ideas to Concepts to Metaphors: the German Tradition of Intellectual History and the Complex Fabric of Language", p. 196-197.
} 
conceitos, principalmente, visa a revelar a fenomenologia do horizonte de compreensão de épocas distintas. ${ }^{140}$

A partir disso, é possível interpretar a narrativa de Arendt realizada em Sobre a Revolução como uma espécie singular de história conceitual. A autora, ao mostrar como as principais figuras das Revoluções Americana e Francesa interpretaram seu tempo e em quais conceitos suas ações estavam ancoradas, refletiu sobre as revoluções do século XVIII articulando fatos com as concepções políticas dos agentes. Em sua narrativa, em primeiro plano estão os conceitos e o deslocamento que eles sofreram com a ação revolucionária.

Vimos que os conceitos mobilizados por Madison sintetizam o sucesso da Revolução Americana em criar uma Constituição duradoura. Sua concepção de poder como algo plural fundamentou a criação de centros de poderes diferentes que poderiam ser combinados para que um poder limitasse o outro e evitasse o surgimento de um governo tirânico. A preocupação com a representação e a purificação de opiniões era pautada na pluralidade e também visava a impedir a tirania. No entanto, a ênfase de Madison e dos federalistas com as instâncias de governo central e com as eleições acabou por negligenciar a participação popular. Jefferson foi, entre os pais fundadores, quem melhor formulou a perda do espírito revolucionário no Novo Mundo. Sua concepção de felicidade, que se referia tanto à vida privada quanto à pública, a defesa do sistema distrital e da revisão constitucional indicaram que a participação ampliada - que fora experimentada no início da revolução - não havia sido resguardada e que era preciso criar instituições e regras para garantir a participação popular.

Com relação à Revolução Francesa, foram as concepções de Sieyès e de Robespierre que indicaram para Arendt o curso do evento. O deslocamento da noção de vontade e soberania, que antes estava relacionada ao monarca e com Sieyès passa a ser vinculada à nação mostra a defesa de uma constituição republicana e coloca a Assembleia Nacional como a principal instância do corpo político. Esta instituição deve, de acordo com ele, decidir sobre os rumos da França. As noções de fundação e virtude defendidas por Robespierre, por sua vez, também indicam a preferência pela constituição republicana. Contudo, quando ele se ocupou principalmente com a compaixão e com a caça aos

\footnotetext{
${ }^{140}$ Conferir em "Form Ideas to Concepts to Metaphors: the German Tradition of Intellectual History and the Complex Fabric of Language", p. 200.
} 
hipócritas, ressaltou a virtude em detrimento das questões institucionais e, com isso, enfraqueceu as leis e as instituições republicanas. Ainda, quando Robespierre passou a entender o ato de fundar como um fazer, centralizou as decisões, recorreu à medidas extraordinárias e à violência. Assim, ele esvaziou o debate público, impossibilitou as deliberações em conjunto e a estabilidade do corpo político.

Levando isso a compreensão dos agentes em conta, isto é, o conjunto das concepções que eles expressaram durante as revoluções, Arendt aponta para o decurso da ação revolucionária na América do Norte e na França e os novos significados dos elementos políticos na Modernidade.

Este modo de tratar as revoluções é bem sucedido em indicar o sentido político da revolução e o significado moderno dos principais conceitos políticos. Entretanto, ao deixar a história social e alguns fatos em segundo plano, Arendt não elucida muito o leitor em alguns aspectos. Por exemplo, na Revolução Americana, a autora não discute muito a atuação dos antifederalistas, além disso, ela não trata da diferença entre o período da República Confederada e o período da República Federal com relação à participação política e à concepção de governo. ${ }^{141} \mathrm{~A}$ autora narra a revolução como um todo e aponta apenas dois marcos históricos: a Declaração de Independência e a Carta Constitucional.

A questão da fundação e do estabelecimento da autoridade, embora discutida por Arendt, poderia ser mais claramente apresentada se a autora apresentasse mais informações históricas sobre o período entre a Declaração de Independência e a ratificação da Constituição. As objeções de Honig acerca do conceito de autoridade e fundação no pensamento arendtiano não seriam pertinentes caso o debate constitucional $\mathrm{e}$ as deliberações nas convenções fossem explorados em Sobre a Revolução.

O mesmo ocorre com relação à narrativa da Revolução Francesa. Algumas questões e problemas levantados por outros autores seriam evitados se Arendt tivesse apontado melhor fatos e informações que corroboram sua análise. Por exemplo, a passagem dos Estados Gerais para a Assembleia Nacional não é acentuada. Dessa forma, a passagem da ação de resistência para a ação fundadora não fica clara, bem como a diferença entre o governo liderado pelos girondinos e o governo liderado pelos jacobinos.

\footnotetext{
${ }^{141}$ Sobre a diferença entre a experiência política na República Federada e na República Confederada ver em Starling, “A Matriz Norte-Americana”, p. 277-291.
} 
Ainda, a autora menciona que nenhuma Carta Constitucional foi duradoura, mas não se refere ao conteúdo das diferentes Constituições, nem discute se as noções de soberania e vontade geral são interpretadas ou usadas de forma diferente em cada um dos textos constitucionais. Isto agregaria à sua análise e evitaria que alguns comentadores entendessem que a questão social foi a causa do fracasso da Revolução Francesa. Nesse sentido, é possível identificar alguns limites e problemas na narrativa arendtiana das revoluções.

De qualquer forma, o ganho deste modo de contar a história das revoluções consiste em apontar a historicidade e o deslocamento dos principais conceitos políticos na Modernidade. Arendt começa sua narrativa tratando da crise geral de autoridade experimentada após a secularização e relaciona a história deste conceito - o surgimento da autoridade política com a fundação de Roma, seu deslocamento no fim do Império romano para a Igreja e sua crise com a Reforma e a Contrarreforma - com a história do conceito de liberdade. Na polis grega e na República romana liberdade era entendida no sentido público e estava relacionada à cidadania, mas assim como o conceito de autoridade, no fim do Império romano, com a redução do espaço público, passa a ser relacionado com o cristianismo. Liberdade, à partir de então, foi entendida como livre arbítrio. No século XVIII, a crise da autoridade e os abusos praticados tanto pela Coroa inglesa como pelo absolutismo francês levaram os homens do Velho e do Novo Mundo a retomarem as noções de autoridade e liberdade antigas. Com isso, os homens escolheram participar dos assuntos comuns e fundar um novo corpo político para garantir a liberdade pública e recuperar a autoridade política.

A autora indica que a Revolução Americana foi bem sucedida em estabelecer uma nova autoridade política e a Revolução Francesa, ao contrário, acabou por fracassar nesta tarefa. A República norte-americana foi capaz de transformar o debate público acerca das regras fundamentais que um corpo político deve ter em uma Carta Constitucional e resguardá-la por meio da Suprema Corte. O papel dos juízes consiste em aconselhar acerca das leis e instituições para manter o equilíbrio do corpo político e a durabilidade do pacto inicial. Já na França, a autoridade foi baseada na vontade da nação e, por ser a vontade volúvel e inconstante, o equilíbrio da comunidade política e o pacto inicial dificilmente poderiam ser mantidos. De acordo coma autora, embora o texto constitucional esteja aberto 
a interpretações distintas, ele é mais fixo e estável que a vontade. ${ }^{142}$ Além disso, a concepção de soberania da nação concebia o poder como um elemento anterior à abertura do espaço político, ou seja, ligava poder ao estado de natureza; com isso, impediu que restrições legais e institucionais delimitassem e bem estabelecessem o poder. Tanto o conceito de soberania quanto a de vontade da nação, tal como reformulados no curso da Revolução Francesa, impediram o estabelecimento de marcos confiáveis e limites para a ação.

No que diz respeito à liberdade, Arendt indica que nenhuma das revoluções foi capaz de institucionalizar os órgãos populares em que a participação ampliada nos negócios públicos seria possível. Isto fica mais claro com o percurso histórico da ação em cada revolução. Na América do Norte, a ação foi iniciada com a contestação do aumento das taxas e impostos e com o tempo se transformou em resistência. A partir da resistência surgiu o debate constitucional e a ação fundadora. Nesse contexto, a noção de resistência foi ampliada. Se antes, ela estava ligada à noção de rebelião e dizia respeito ao direito de trocar o governante quando este abusava de sua autoridade ou trocar a forma de governo corrompida por uma forma reta, com a Revolução Americana, resistência passou a significar que os povos têm o direito de romper com governos tirânicos e estabelecer para si um corpo político próprio e novo.

Arendt indica que ao cabo do debate constitucional na América do Norte, como o termo felicidade em sua conotação pública não foi registrado em nenhum texto oficial e como as associações voluntárias, as assembleias municipais e provinciais não foram inscritas na Carta Constitucional, o direito de participação nos assuntos comuns foi restrito aos representantes do povo e apenas a felicidade privada foi garantida. Nesta perspectiva, a

\footnotetext{
${ }^{142}$ Arendt, em Sobre a Revolução, indica que a República norte-americana é dotada de autoridade, contudo, em Crises da República, a autora indica que esta autoridade entrou em crise por duas razões: primeiro, os índios e negros não fizeram parte do pacto constitucional, não puderam participar dos negócios públicos na revolução, uma vez que não possuíam igual direito de falarem e serem ouvidos. Os movimentos por direitos civis da década de 1950 estavam justamente reivindicando uma repactuação que dotasse estas minorias de direitos iguais. O segundo motivo consiste na 'doutrina da questão política', que colocou em cheque a estabilidade do corpo político nos EUA. Esta doutrina defende que certos atos do Legislativo e do Executivo não podem ser revisados pelo Judiciário. Na interpretação da autora, tal doutrina é, na verdade, "o buraco pelo qual o princípio da soberania e a doutrina da razão de Estado podem se infiltrar" nos EUA, uma vez que o termo soberania está ausente da Constituição. Nesse contexto, Arendt defende a inscrição legal da desobediência civil no ordenamento com o objetivo de remediar as falhas que possam surgir com o impedimento da revisão judicial. Em outras palavras, Arendt defende o acolhimento, na Constituição, das ações de associações voluntárias e do direito de divergir. Conferir em Crises da República, p. 88-89.
} 
liberdade de empreendimento e a busca do bem-estar individual se tornaram a principal herança desta revolução.

$\mathrm{Na}$ França, o espaço público foi iniciado por meio do debate entre autores e leitores na medida em que o papel dos homens de letras foi central para identificar a monarquia com tirania, para ampliar a discussão sobre os assuntos comuns e promover o apreço pela liberdade política. De forma resumida, o debate aberto pelos homens de letras preparou os franceses para a ação. Quando o rei convocou os Estados Gerais, o povo estava preparado para votar, escrever suas queixas. Mais do que isso, o povo estava disposto a formar clubes, comunas e sociedades para debater e orientar seus delegados por meio de cartas e manifestações. O desenvolvimento deste debate ampliado culminou na percepção de que a França carecia de direitos e instituições bem estabelecidos e que era preciso agir para fundar um novo corpo político. Nesse contexto, o espaço mundano aberto por meio da escrita se tornou espaço público e abriu espaços para o discurso e a ação.

Já indicamos os motivos pelos quais as Cartas Constitucionais escritas na França de 1789 a1794 não tiveram durabilidade. Além desta instabilidade causada pela sequência de Constituições, a noção de que a vontade geral poderia ser representada pela Assembleia Nacional e a concepção de fundação como fazer promoveram a centralização do poder e das decisões. Contudo, a ação não sucumbiu apenas em razão da fragilidade institucional e da centralização, as noções de soberania e de fundação estimularam o uso da violência. Assim, a participação ampliada experimentada no início da revolução foi reduzida com a centralização e arruinada com o terror.

Levando isso em conta, vemos que a articulação dos deslocamentos dos conceitos no tempo e espaço indica as origens, os percursos e o fim das duas revoluções do século XVIII. Podemos afirmar, em vista disso, que Arendt produz uma narrativa história dos conceitos na medida em que faz um paralelo entre os fatos e as mudanças nos conceitos e interpreta o significado dos eventos por meio do horizonte de compreensão dos principais atores revolucionários. 


\section{Capítulo 3: O tesouro perdido das Revoluções}

No primeiro capítulo desta tese, mostramos que as categorias tradicionais não são capazes de explicar os eventos revolucionários em razão das novidades que surgiram com tais eventos. Também indicamos no primeiro capítulo que, para Arendt, o marxismo e o liberalismo não tratam adequadamente dos eventos revolucionários. A seguir, esta crítica da autora será retomada a propósito de indicar que o pensamento marxista, apesar de tratar do conceito de revolução, negligencia categorias e experiências políticas fundamentais, como as novas concepções de governo e de constituição que surgiram com os conselhos revolucionários. Já o liberalismo não valoriza os eventos revolucionários e oblitera essa experiência política ao promover concepções de representação e governo que visam a reduzir o espaço público.

No segundo capítulo desta tese, tratamos das narrativas das revoluções Americana e Francesa. Com estas narrativas, Arendt mostra que a crise da autoridade e o gosto pela liberdade estavam nas origens das revoluções. Os homens no Novo e no Velho Mundo perceberam que a monarquia governava ilegitimamente, pois perdera o apoio e o consentimento dos súditos. Neste contexto, graças ao apreço pela liberdade pública, muitos 
resolveram se responsabilizar pelo mundo e agir para estabelecer uma nova autoridade e um novo poder. ${ }^{1}$

Além de discutir as origens dos dois eventos revolucionários do século XVIII, apresentamos o curso e o desfecho de cada um deles por meio das concepções políticas dos principais agentes envolvidos nestes eventos. Em outras palavras, tratamos das concepções que, segundo Arendt, moveram os atos e discursos dos revolucionários, e de como elas foram ressignificadas nas revoluções e de que modo impactaram o pensamento e a política a partir do século XIX.

Para continuar a apresentar nossa leitura acerca da obra Sobre a Revolução, neste capítulo discutiremos a história de outros conceitos centrais para a atividade política e que estão intimamente ligados aos eventos revolucionários, tais como fundação, constituição, representação e governo. Tratar-se-á de indicar a definição original destes conceitos e os novos significados que surgiram com as revoluções. Veremos que, diante da polissemia destes conceitos, alguns significados foram negligenciados. Ao levar isso em conta, Arendt procura indicar as mudanças de significado nestes termos ao longo do tempo, também problematiza as concepções de fundação, constituição, representação e governo elaboradas pela teoria política contemporânea e recupera o sentido político esquecido destes termos.

Ainda neste capítulo, trataremos da narrativa arendtiana sobre o aparecimento recorrente e a derrota do sistema de conselhos em diversos levantes revolucionários. $\mathrm{O}$ surgimento do sistema de conselhos possibilitou a ação ampliada e o mais alto grau de liberdade, por isso, para Arendt, ele foi o maior responsável pelo pathos de novidade nas revoluções. Nesse sentido, os novos significados dos conceitos estão vinculados à experiência política dos conselhos.

Em nossa perspectiva, por meio da história dos conceitos e da narrativa sobre os conselhos, a autora revela o tesouro perdido das revoluções e o modo pelo qual surgiram algumas concepções que dificultam a compreensão do mundo contemporâneo. Para ela, o tesouro perdido consiste na liberdade e nas formas de ação que não tinham sido previstas pela tradição e que não foram legadas para o futuro por meio das teorias de seu tempo. ${ }^{2}$

\footnotetext{
${ }^{1}$ Conferir em Crises da República, p. 177.

2 Arendt formulou esta imagem do tesouro perdido a partir do aforismo de René Char. Conferir em Entre $O$ Passado e o Futuro, p. 28-31.
} 
Nesse sentido, a autora chama a atenção para o esvaziamento do sentido político de alguns termos, que com a tradição revolucionária passaram a ser relacionados com as questões sociais, e, com a tradição liberal, passaram a ser associados ao governo limitado e à promoção da vida privada.

Entendemos que buscar a genealogia dos conceitos e seu deslocamento com as revoluções faz parte de um esforço de compreensão do mundo na medida em que esse procedimento aponta as potencialidades da atividade política a partir da Modernidade, as dificuldades para preservar a ação e o espaço público, e os conceitos e teorias que desfavorecem a reflexão política e o engajamento na ação. Nesse sentido, Arendt, ao criticar tais teorias e ao formular seus próprios conceitos, reafirma a dignidade da política.

\subsection{Fundação}

Na perspectiva arendtiana, a fundação está relacionada ao início do espaço político, à sua durabilidade e às renovações e mudanças nos assuntos públicos. De acordo com a nossa leitura de Sobre a Revolução, a autora muitas vezes indica a história de um conceito para tratar dos deslocamentos que os eventos revolucionários promoveram na esfera pública, para indicar as possibilidades e riscos da ação na Modernidade e para debater com a tradição e o pensamento político de seu tempo. Com a noção de fundação ocorre o mesmo: a autora recupera o sentido antigo e tradicional de fundar, depois indica seu limite e sua capacidade para ajudar a compreensão do mundo contemporâneo; ela ainda mostra a novidade que as revoluções trouxeram para o conceito de fundação e problematiza as interpretações de seu tempo sobre este conceito.

A autora, para discutir a fundação, retoma Roma em duas dimensões distintas, a saber, o mito de origem da cidade e as concepções políticas republicanas. Além disso, ela recupera a origem do termo fundação em latim. $O$ ato de fundar uma cidade não é, evidentemente, um fenômeno de origem romana; as cidades gregas, por exemplo, foram constituídas antes. Entretanto, foi em Roma que a fundação se tornou central para toda a vida política da cidade e estava vinculada com todos os grandes feitos dos cidadãos e com a grandeza da república que tomou forma com os anos. Para ela, é impossível entender os 
conceitos políticos romanos sem considerar o início da história e da cronologia de Roma. ${ }^{3}$ Nesse sentido, fundação conciliava permanência e mudança, uma vez que o ato inicial se estendia por toda a história da cidade, que era alargada e aumentada de acordo com o princípio que lhe deu origem. As mudanças na vida política não rompiam o vínculo com o ato fundador.

"Como a autoridade significava o aumento das fundações, Catão podia dizer que a constitutio rei publicae não era 'a obra de um único homem nem de uma única época'. Em virtude da auctoritas, a permanência e a mudança estavam unidas [...]" (Sobre a Revolução, p. 259).

Para ilustrar que fundação está relacionada com renovação e conservação, a autora também trata da palavra latina que designava o ato de fundar. Condere era derivada do nome do Deus Conditor, responsável por presidir o crescimento da colheita. A função deste Deus era iniciar e preservar, cultivar e fazer crescer. ${ }^{4}$

Como foi mencionado antes, na Antiguidade, o início foi tratado primeiramente por mitos e lendas de fundação cujo papel era indicar como um evento irrompeu no contínuo do tempo histórico. Segundo Arendt, os homens da revolução conheciam duas lendas. A primeira consistia na narrativa bíblica sobre o êxodo das tribos de Israel, que se libertaram ${ }^{5}$ da escravidão no Egito e partiram em busca da terra prometida; a segunda era a lenda da fuga de Eneias da cidade de Troia que estava completamente destruída pela guerra. Nessa narrativa, após escapar da destruição, o herói, por fim, chegou à península itálica e fundou uma cidade.

Dentre estas duas lendas, Arendt destaca o poema de Virgílio sobre Eneias. A violência não teve papel relevante nesta narrativa da fundação de Roma, ela ficou restrita às armas usadas na guerra de Troia. $\mathrm{O}$ que permitiu o ato de fundação nesta lenda foi um pacto: um tratado que associou os dois povos que passaram a residir no local. ${ }^{6}$ Em outras palavras, na perspectiva da autora, este início lendário apontava para o princípio de associação que perdurou durante toda a história da cidade: os romanos deveriam ampliar a fundação de Roma por meio de alianças com outros povos.

\footnotetext{
${ }^{3}$ Conferir em Sobre a Revolução, p. 265.

${ }^{4}$ Ver em Sobre a Revolução, p. 260.

5 As lendas tratam de libertação [liberation], no sentido, anteriormente apresentado, de livrar-se da dominação de outrem.

${ }^{6}$ Conferir em Sobre a Revolução, p. 266.
} 
Ao contrário, outras narrativas, como as lendas de Rômulo e Caim, davam destaque ao fratricídio e, com isso, propiciaram a emergência da concepção de que, antes de fundar um corpo político, era preciso um ato extraordinário que envolvesse necessariamente violência, a repetição do crime lendário.

Apesar desta diferença no que concerne o papel da violência no ato fundador, na leitura da autora, tanto a narrativa bíblica quanto a de Virgílio tratam da libertação [liberation] e da promessa de liberdade [freedom]. Elas indicam que há um intervalo entre a fuga da dominação - da escravidão ou da destruição da guerra - e o início de uma nova vida em uma nova cidade.

"Se essas lendas ensinam alguma coisa, é que a liberdade não é o resultado automático da libertação, da mesma forma que o novo início não é a consequência automática do fim" (Sobre a Revolução, p. 263).

Contudo, este hiato lendário entre libertação e liberdade não indica com clareza a ação humana capaz de estabelecer um novo corpo político, de instituir o espaço de liberdade. Em outras palavras, se, por um lado, as lendas ajudam a compreender a diferença entre se libertar do domínio de outrem e estabelecer um espaço onde a ação livre pode aparecer, por outro, não lançam luz sobre o ato de constituição do espaço públicopolítico. Somente com as revoluções no século XVIII este ato pode ser analisado pelo pensamento político.

Além disso, as lendas não tratam da relação entre a ação humana e a aparição do novo no mundo público. Os atos dos fundadores estão ligados aos deuses: Moisés foi guiado pela providência divina e Rômulo era filho de Marte, assim, se alguma novidade apareceu no mundo, ela tinha qualidade divina. Já o poema de Virgílio não vincula o ato de fundar Roma com novidade, uma vez que Eneias não visava a fundar uma cidade totalmente nova, mas refundar Troia.

Além de interpretar os mitos de fundação, a autora retoma a concepção deste conceito nos pensadores políticos, principalmente em Cícero e Maquiavel. Arendt não expressa claramente o motivo pelo qual ela escolhe estes dois autores, mas, a partir da sua crítica à concepção grega de lei e à filosofia política, podemos inferir este motivo. Para a autora, na concepção grega, o legislador que funda ou reforma a cidade faz o mesmo que um arquiteto: constrói os muros que delimitam o espaço público, mas se mantém fora da condução das questões políticas, não se torna necessariamente habitante ou participante do 
espaço que construiu. ${ }^{7}$ Além disso, a filosofia política iniciada por Platão afirma que a relação entre governantes e governados é semelhante à relação entre o senhor e o escravo. Os primeiros sabem o que deve ser feito e, por isso, devem dar ordens, enquanto os outros devem apenas obedecer e executar ordens. ${ }^{8}$ Por fim, na visão da autora, na tradição filosófica, a discussão acerca da melhor forma de governo buscava um modelo baseado mais nas ideias e na razão do que nos atos e eventos no espaço público.

Cícero, por sua vez, procurou tratar da comunidade política levando em conta a doutrina filosófica, a prática nos negócios públicos e a experiência dos antepassados. Dessa forma, ele procedeu de modo diferente dos filósofos, pois não forjou na mente a melhor forma de governo. ${ }^{9}$ De maneira semelhante, Maquiavel afirmou que existe uma distância entre como se deveria viver e a forma como se vive, por esta razão, o pensamento político deve considerar as repúblicas e os principados verdadeiros, não deve tratar de formas de governo imaginadas, que nunca foram vistas. ${ }^{10}$ Ainda, para ambos os autores, o fundador não está fora da cidade, ele, mais do que participante dos assuntos públicos, torna-se o principal cidadão ao ordenar a república.

De acordo com Arendt, em Cícero e Maquiavel, aquele que funda ou reforma uma república é capaz de colocar a lei acima dos homens na medida em que centraliza a autoridade e é dotado de engenho divino ou de virtù. ${ }^{11}$ Para ilustrar isso, Arendt trata do livro VI da obra De Republica, em que Cícero faz um apelo a Cipião para se tornar ditador e reconstituir a esfera pública que fora perturbada. ${ }^{12}$

É curioso o fato de que a autora trata mais deste trecho do De Republica e pouco discute os livros I e II, em que o Cícero disserta sobre a melhor forma de organização política que um povo pode constituir e narra a história de Roma. Estes dois primeiros livros são relevantes para discutir as concepções romanas de fundação e de república. Por isso, iremos aqui indicar brevemente como o autor apresenta estes dois temas e relacioná-los

\footnotetext{
${ }^{7}$ Ver em Sobre a Revolução, p. 241 e 242.

8 “O senhor, segundo a discussão em $O$ Político, sabe o que deve ser feito e dá ordens, enquanto o escravo as executa e obedece, de tal modo que saber o que fazer e realmente fazer se tornam funções separadas e mutuamente exclusivas" (Entre o Passado e o Futuro, p. 148).

${ }^{9}$ Conferir em De Republica, Livro II, 3.

${ }^{10}$ Ver em $O$ Príncipe, capítulo XV.

${ }^{11}$ Conforme Cícero, os homens se aproximam dos deuses quando agem para fundar uma comunidade política ou conservá-la. Ver em De Republica, Livro I, 12. Além disso, o autor afirma que a virtude de Rômulo o conduziu ao céu. Conferir em De Republica, Livro I, 25.

${ }^{12}$ Conferir em Sobre a Revolução, p. 265.
} 
com o pensamento de Arendt, para, em seguida, tratar da interpretação da autora sobre o último livro do De Republica.

No primeiro livro, Cícero inicia o diálogo entre os varões ilustres de Roma e dá voz a Cipião para tratar do melhor estado da ciuitas. Ele inicia sua narrativa ao apresentar a diferença entre o espaço urbano, a ciuitas e a república. A urbes ou fortificação é formada por santuários e praças comuns, consiste no espaço físico da cidade. A ciuitas consiste num conjunto de homens associados por uma lei natural que os agrega em uma comunidade. Não existe aqui concílio ou deliberação em relação à lei. O autor, com isso, afirma que os homens que vivem em uma mesma fortificação não formam necessariamente um povo, uma vez que um povo não é uma multidão agrupada de qualquer modo, mas se constitui de homens reunidos por uma utilidade comum e por um consenso quanto ao que é justo. ${ }^{13}$

A república, ou seja, a coisa do povo, só pode surgir a partir da reunião do povo em torno de uma utilidade comum e de um acordo sobre o que é justo. Nesta perspectiva, o governo de um tirano, de uma facção ou de uma turba destrói a república, isto é, a coisa comum aos cidadãos. Nesse sentido, para ser conservada, ela deve ser conduzida de acordo com o princípio de justiça que a gerou.

Esta passagem do texto de Cícero ajuda a esclarecer algumas noções arendtianas. Notadamente, elucida a afirmação da autora no que concerne a artificialidade presente no corpo político. Para ela, a política não tem o papel de organizar a vida da comunidade para garantir a sobrevivência, isto é, não é uma forma de convivência baseada na natureza. ${ }^{14} \mathrm{~A}$ política se dá no espaço entre os homens: onde diversas opiniões podem ser trocadas, onde algo pode ser compartilhado por todos, de modo a separar e relacionar cada um. Somente neste espaço pode surgir uma coisa que enter-essa. Além disso, a diferenciação entre o espaço físico, a comunidade política e a forma de conduzi-la é particularmente interessante para entender algumas afirmações de Arendt com relação às revoluções. Se uma população compartilha somente os costumes, a língua e o local de nascimento, mas não possuiu um princípio público que vincule as pessoas, um povo não se constituiu e não institui por meio da ação uma forma de conduzir os negócios públicos. Para Arendt, a revolução na América do Norte envolveu a constituição de um povo: aqueles que viviam nas treze colônias, no

\footnotetext{
${ }^{13}$ Sobre urbes conferir em De Republica, livro I, 41; e sobre povo ver livro I, 39.

${ }^{14}$ Conferir em A Promessa da Política, p. 164.
} 
momento em que elegeram um princípio de justiça comum, passaram a ter vínculos públicos e procuraram estabelecer um corpo político condizente com este princípio. $\mathrm{Na}$ França, os abusos do absolutismo tinham destruído a coisa pública e a possibilidade dos homens se relacionarem por meio de princípios compartilhados. Nesse contexto, a partir da eleição para os Estados Gerais e das queixas enviadas aos representantes, o povo se reconstituiu e se rearticulou. Em ambos os casos, foi preciso primeiro que os povos se associassem como tal para que fosse possível fundar instituições e leis condizentes com o senso de justiça comum.

Ainda, a afirmação de Cícero de que a coisa pública surge quando há um consenso entre os cidadãos quanto ao que é justo ajuda a iluminar a noção apresentada por Arendt de que todo início carrega um princípio. Segundo a autora, enquanto a fundação for lembrada, o senso compartilhado que estava em sua origem mantém os membros da comunidade política vinculados publicamente e inspira suas ações. Ela cita Platão para tratar deste tema: "Pois o início, porque contém seu próprio princípio, é também um deus que, enquanto mora entre os homens, enquanto inspira seus feitos, tudo salva" (Sobre a Revolução, p. 272). Embora as palavras do filósofo grego indiquem a melhor formulação sobre a relação entre início e princípio, são os escritos de Cícero sobre Roma que descrevem o vínculo entre a abertura do espaço público-político, a constituição do povo e os atos das gerações vindouras.

O pensamento ciceroniano reafirma que a concepção romana de fundação não envolvia a criação do novo. A melhor forma de conduzir a coisa pública, de acordo com Cícero, consiste em temperar e misturar três gêneros já conhecidos: o governo régio, o dos optimates e o popular. Para ele, os gêneros não mesclados carregam em si alguns vícios. ${ }^{15}$ Levando isso em conta, o autor entende que a reordenação das instituições ao longo dos anos - o estabelecimento do Consulado, do Senado e do Tribunato da Plebe - mesclou os três gêneros de governo com base nas experiências passadas: nas ordenações de Licurgo, Sólon, entre outros legisladores e nos atos dos patres. Nesse sentido, a república romana não fez surgir novidade alguma, apenas mesclou gêneros já existentes. ${ }^{16}$

\footnotetext{
${ }^{15}$ Ver em De Republica, Livro I, 43.

${ }^{16}$ Conferir em De Republica, Livro II, 2.
} 
Na narrativa de Cícero sobre a fundação da cidade, não é mencionado o assassinato de Remo ou o consentimento na morte de Tácio Sabino. O autor apresenta a primeira forma da ordenação de Roma utilizando em parte a lenda e em parte os fatos. Por um lado, ele afirma que Rômulo era filho de Marte e se tornou imortal (este fundador não teria morrido, mas desaparecido sobre um monte num dia em que a lua eclipsou o sol). Por outro lado, Cícero busca datar a fundação de Roma de acordo com os anais gregos e trata da forma como a cidade foi dividida e o conselho régio estabelecido. ${ }^{17}$

Após indicar os feitos dos reis que sucederam Rômulo, o autor mostra o desvirtuamento do poder régio que foi realizado por Tarquínio, o Soberbo. Ele reinava sem a ordem do povo e sem consultar a autoridade dos cidadãos mais eminentes. Após muitas ofensas e atos torpes, os Tarquínios foram expulsos. Mas isso não bastou para o povo de Roma, que, receoso de que uma tirania pudesse vir a se instalar na cidade novamente, recusou aceitar mais um rei. Neste contexto, o exemplo de Rômulo de reunir os melhores cidadãos para aconselhar a condução dos negócios públicos foi recuperado e o Senado foi estabelecido. No lugar do poder régio foram instituídos dois consulados com mandatos breves, de apenas um ano, para evitar a usurpação do cargo. ${ }^{18}$

Não muito tempo mais tarde, dezesseis anos, de acordo com Cícero, o povo almejou mais direitos e ocupou o Monte Sacro e o Monte Aventino. A partir desta rebelião da plebe, foram instituídos os Tribunos com o intuito de temperar a autoridade do Senado e o comando consular. ${ }^{19}$ Cícero afirma que os Tribunos da Plebe foram inspirados nos Éforos de Esparta, que tinham o papel de diminuir a força régia na cidade. Nesta perspectiva, as instituições romanas não foram entendidas como novas, pois eram inspiradas nos exemplos dos antepassados.

Nota-se que tanto para Arendt quanto para Cícero a vida política envolve uma pluralidade de agentes. A narrativa do autor romano indica que a fundação envolve diversos cidadãos de muitas gerações. Entretanto, os autores se distanciam no que concerne às qualidades políticas daqueles que agem com excelência dentro do espaço público. Da perspectiva da autora, Cícero não contribui com o pensamento político quando recorre ao

\footnotetext{
${ }^{17}$ Conferir em De Republica, Livro II, 14 e 18.

${ }^{18}$ Sobre o reinado de Tarquínio, o Soberbo, ver em De Republica, Livro II, 37-38. Com relação à instituição dos dois Consulados, ver em De Republica, Livro II, 56.

${ }^{19}$ Ver em De Republica, Livro II, 57 e 59.
} 
mito e indica qualidades divinas em Rômulo: dessa forma, ele faz um apelo aos céus para explicar o problema inerente ao início de um corpo político. As leis foram colocadas acima dos homens na medida em que o ordenador foi considerado divino.

Arendt também indica isso ao mencionar o livro VI da obra De Republica, em que Cipião conta sobre o sonho que teve com seu avô alguns anos antes. Nesta visão profética é anunciado para Cipião que, em dois anos, ele se tornaria cônsul e destruiria Cartago. Depois de outros grandes feitos, seria reconduzido ao consulado. Ao voltar da guerra contra a Numância para Roma, encontraria a república perturbada pelas ideias de seu primo Tibério Graco. A partir deste momento, o destino de Cipião seria incerto: poderia encontrar a morte - o que, de fato ocorreu - ou, se conseguisse escapar das mãos de seus parentes, seria nomeado ditador e salvaria a república. Após anunciar esta trajetória que tornaria Cipião um dos cidadãos mais ilustres da história romana, seu avô afirma que todo aquele que conserva ou ajuda a pátria torna-se de certo modo divino, imortal, podendo habitar a órbita mais alta do céu, próximo dos deuses. ${ }^{20}$

A autora não interpreta o sonho de Cipião simplesmente como um elogio aos homens de grande engenho e virtude, ou como forma de encorajar a dedicação à vida pública e preceituar o desenvolvimento da virtude. Ela entende que Cícero - ao afirmar que, caso Cipião escapasse da morte, ele salvaria a república - desejava que tal cidadão se tornasse ditador e reordenasse a coisa pública. Esta passagem mostra o apreço pela Ditadura e o louvor das qualidades divinas de Cipião. Para Arendt, isto abre espaço para a defesa da redução do espaço político e para um apelo aos céus a fim de resolver emergências políticas. Esta passagem, segundo a autora, enseja a concepção de que em situações de emergência deve-se confiar mais nas decisões de um homem com características divinas do que no debate ampliado e nas deliberações comuns. Na sua perspectiva, a instituição da Ditadura romana se desenvolveu na Modernidade e provocou a redução do espaço público e o uso da violência para fazer uma república ou reformá-la.

Segundo Arendt, a Ditadura romana, apesar de concentrar poder nas mãos de um cidadão, não envolvia a concepção de que a política deveria ser realizada aos moldes da fabricação. $\mathrm{O}$ ditador não imprimia sua ideia no corpo político, como se os cidadãos e o

\footnotetext{
${ }^{20}$ Conferir em De Republica, Livro VI, 11-13, 18, 20, 21 e 26.
} 
espaço político fossem um material que pode ser moldado conforme sua vontade. ${ }^{21}$ Sabe-se que a função do ditador em Roma era comandar o exército, decretar leis e pronunciar sentenças pelo tempo em que vigorasse sua autoridade, no máximo seis meses. Seu objetivo consistia em sanar situações de emergência, como guerras e crises internas. Este poder extraordinário poderia ser instituído somente com aprovação do Senado e a indicação dos cônsules. Nesse sentido, a ditadura não anulava completamente as outras instâncias políticas. Já no declínio da República romana, Júlio César distorceu esta instituição quando, ocupando o cargo de cônsul, declarou-se ditador vitalício. Assim, ele colocou sua autoridade acima do Senado e dos Tribunos da Plebe. ${ }^{22}$

Nas revoluções, conforme a autora, esta distorção da Ditadura foi reforçada: a noção de que quem possui qualidades notáveis pode se colocar acima das instituições e do corpo político para comandar os demais foi retomada. Robespierre, tendo sido considerado um dos mais virtuosos homens da revolução, incorruptível, entendeu que poderia recorrer a atos extraordinários para constituir ou reconstituir a esfera pública. Embora ele não tenha se declarado ditador vitalício, ele passou por cima das instituições e leis ao centralizar as decisões e ao usar da violência. ${ }^{23}$

Como foi mencionado no capítulo anterior, para Arendt, Robespierre também se apoiou no pensamento de Maquiavel. De acordo com ela, este autor, ao mesmo tempo em que valoriza a política, traz problemas para pensar a ação. Por um lado, Maquiavel articula a experiência política romana em detrimento da doutrina cristã e da filosofia política grega e sustenta que a experiência da fundação de um corpo político duradouro poderia ser repetida na Modernidade. Mas, por outro lado, abre espaço para o uso da violência dentro da comunidade política, principalmente ao afirmar que, para fundar ou reformar uma república, é preciso estar só, e ao insistir em que a violência é um meio justificado para atingir a fundação como fim. ${ }^{24}$

\footnotetext{
${ }^{21}$ Ver em Sobre a Revolução, p. 267.

22 Cícero, embora tenha elogiado Cipião e tenha considerado que sua ditadura teria salvado a República, romana, foi um dos maiores opositores de César. Ele participou de seu assassinato no Senado e posteriormente, em Dos Deveres, defendeu este ato violento. Isso mostra que Cícero vituperava a ditadura vitalícia.

${ }^{23}$ Conferir em Sobre a Revolução, p. 265.

${ }^{24}$ Ver em Entre o Passado e o Futuro, p. 182-185.
} 
Maquiavel, ao tratar do princípio das cidades, mostra que a fundação envolve tanto a edificação - a escolha do lugar em que a cidade será construída - como a ordenação do corpo político - o estabelecimento de leis que refreiam os cidadãos, sua ambição e seus desejos, a forma como a autoridade é distribuída, como são eleitos magistrados e o modo de se criar leis. ${ }^{25}$

Para o autor, duas são as formas pelas quais uma cidade recebe leis e ordenações, a saber, de um só homem e de uma só vez, como ocorreu com Esparta quando Licurgo estabeleceu as leis; ou em várias vezes de acordo com os acontecimentos, como ocorreu em Roma. Nesta cidade, os primeiros ordenamentos foram feitos com a finalidade de fundar um reino, eles se tornaram insuficientes quando os Tarquínios usurparam o poder. $\mathrm{Na}$ ocasião da expulsão dos Tarquínios, a cidade foi reordenada e a autoridade foi distribuída entre o Senado e dois cônsules. Com o tempo, a nobreza se tornou insolente e outra ordenação foi necessária. A criação dos Tribunos da Plebe trouxe novamente estabilidade à república. De acordo com Aranovich:

"Comparando isso com a posição de Cícero, para quem as instituições condensavam o saber de gerações de homens sábios e, portanto, eram melhores, veremos que Maquiavel considera que as instituições não necessariamente se aperfeiçoam com o tempo e que apenas o encontro frequente entre os tempos e as ordenações seria empecilho à ruína" ("O Riscontro: considerações sobre a política e a história em Maquiavel”, p. 76).

A comentadora aponta que, no pensamento maquiaveliano, os modos de proceder devem estar de acordo com a natureza dos tempos, isto é, o homem não pode agir como deseja, ele deve antes levar em conta os tempos e adaptar seu modo de proceder a eles. ${ }^{26}$ Da mesma forma, o corpo político para ser duradouro não pode ser fixo: uma vez que as coisas do mundo mudam, o corpo político deve ser flexível, mudando as ordenações conforme os tempos para evitar a ruína. ${ }^{27}$ Aqui fica claro que, para o pensador florentino, embora o momento inicial da cidade seja importante, ele não fixa e petrifica completamente a vida política. Pode-se afirmar, então, que Arendt também se apoia em Maquiavel ao afirmar que a fundação envolve tanto a permanência como a mudança.

Com relação à avaliação entre o melhor modo de fundar uma cidade, Maquiavel, ao comparar a longevidade de Esparta e Roma e os tumultos perigosos que surgiram em cada

\footnotetext{
${ }^{25}$ Sobre ordenações, ver em Discursos sobre a primeira década de Tito Lívio, Livro I, 18, p. 73.

${ }^{26}$ Conferir em "O Riscontro: considerações sobre a política e a história em Maquiavel”, p. 78.

${ }^{27}$ Ver em "O Riscontro: considerações sobre a política e a história em Maquiavel”, p. 82.
} 
uma, conclui que é melhor receber as leis de um homem prudente e de uma vez só. De acordo com ele, para que uma cidade seja bem ordenada, a autoridade deve ser concentrada nas mãos de um só, a fim de que este possa moldar a primeira forma do corpo político. Um grupo de homens dificilmente consegue imprimir uma forma à cidade em razão das diferentes opiniões que possuem entre $\operatorname{si}^{28}$

Nesse sentido, o autor entende que, para ordenar uma república, deve-se estar só. Ele retoma o exemplo de Rômulo que, além de ter assassinado o irmão, consentiu na morte de Tito Tácio Sabino para que pudesse legislar. Rômulo usou da violência somente para bem constituir o corpo político: logo ordenou um Senado para lhe aconselhar, isto é, entregou a coisa pública aos cuidados de muitos, e delimitou a autoridade do rei. Nas palavras do autor, "Cumpre que, se o fato o acusa, o feito o escusa; e quando o efeito for bom, como o de Rômulo, sempre o escusará: porque se deve repreender quem é violento pra estragar, e não quem o é para consertar" (Discursos sobre a primeira década de Tito Lívio, Livro I, 9, p. 41).

Na perspectiva de Arendt, esta afirmação de que um homem deve estar só para fundar uma república, a concepção de que a violência pode ser usada para fundar ou renovar o corpo político e a noção de que a forma da cidade está na mente do legislador que deve imprimi-la na matéria ao dispor as leis e as instituições permitem que a concepção maquiaveliana de fundação seja interpretada como fabricação. Na concepção da autora, fabricar é a atividade que visa a produzir algo de acordo com uma ideia que define a forma do produto e os meios de fazê-lo. Esta atividade consiste na transformação de matérias naturais em produtos, por isso, geralmente, envolve a força e a violência.

Para a autora, esta relação entre a fabricação e $\mathrm{o}$ ato de fundar se tornou especialmente perniciosa quando nenhuma constituição foi ratificada na Revolução Francesa e a concepção de revolução permanente ganhou força. Isto abriu espaço para o terror: a violência foi constantemente usada para fazer o corpo político funcionar e para coagir os cidadãos a se conduzirem de acordo com a ideia daquele que se intitulava o

\footnotetext{
${ }^{28}$ Conferir em Discursos sobre a primeira década de Tito Lívio, Livro I, 2.
} 
fundador. $^{29}$ Encontramos a ligação entre algumas das concepções de Cícero e de Maquiavel com as ideias de Robespierre na seguinte passagem de Sobre a Revolução:

"A solução romana corrente do problema, inerente a esse início, encontra talvez sua melhor indicação no famoso apelo à Cipião, para que se torne dictator rei publicae constituendae que estabeleça a ditadura para o momento crucial de constituir - ou melhor, reconstituir - a esfera pública. A república em sua acepção original. Essa solução romana foi a fonte efetiva de inspiração para o 'despotismo da liberdade' de Robespierre, que, se quisesse justificar sua ditadura em defesa da constituição da liberdade, poderia muito bem recorrer a Maquiavel: 'Fundar uma nova república, ou reformar inteiramente as velhas instituições de uma república existente, deve ser trabalho de um só homem' [...]" (Sobre a Revolução, p. 265).

Embora o ato do fundador seja importante para Maquiavel, o princípio da cidade e a forma dada pelo primeiro ordenador não determinam por completo a vida política, as alterações são inescapáveis: com o tempo, o corpo político se corrompe, o conflito dos humores na cidade produz novas leis e com isso renovações são necessárias para reordenar a cidade e mudar a conduta dos homens. Segundo o autor, as renovações retomam o vigor inicial do corpo político, voltam ao princípio, prolongam a vida da república, que, caso fosse deixada aos cuidados da fortuna, encontraria cedo ou tarde a corrupção e a ruína. Nesse sentido, renovação não significa criar algo inédito, nunca antes experimentado, mas tentar imprimir na matéria uma forma conhecida, recriar o princípio.

Arendt parece concordar com Maquiavel em que existe uma ligação entre a fundação e o desenrolar da vida política posterior. Para ela, o modo como o corpo político é iniciado carrega em si um princípio que se torna a lei da ação. Isto é, o princípio inspira os atos vindouros e se estende até o fim. ${ }^{30}$ Além disso, a autora aprecia o interesse do autor pela questão da durabilidade das repúblicas. Maquiavel estuda as mudanças das constituições e a corrupção com o objetivo de remediar a instabilidade na vida pública, reflete sobre a fundação de um corpo político duradouro, estável. Tal preocupação foi

\footnotetext{
${ }^{29}$ Maquiavel, embora entenda que a violência possa ser usada para fundar ou renovar uma república, adverte que meios extraordinários não devem ser deixados à disposição dos cidadãos que sucederem o ordenador, pois a autoridade e a violência usadas para o bem e a utilidade comum em uma ocasião podem ser usadas por ambição e em favor das coisas privadas em outro momento (ver em Discursos sobre a primeira década de Tito Livio, Livro I, 9, p. 42). Nesse sentido, o autor parece querer evitar que os homens públicos recorram sempre a meios extraordinários diminuindo a possibilidade da violência ser usada por muito tempo e contra muitos homens. Além disso, ao tratar de Agátocles, Maquiavel afirma que a violência deve ser aplicada de uma vez só. Conferir em $O$ Príncipe, capítulo VIII.

${ }^{30}$ Ver em Sobre a Revolução, p. 272.
} 
central para os homens do século XVIII engajados em levantes revolucionários. Por isso, o pensamento maquiaveliano foi retomado nas revoluções setecentistas.

Contudo, Arendt aponta para um deslocamento na concepção de fundação a partir das revoluções, que, além de comportar a preocupação com a estabilidade do corpo político, passa a carregar o pathos de novidade. $\mathrm{Na}$ concepção dos antigos e do autor florentino, a vida política comportava mudanças: as cidades se corrompiam, podiam ser renovadas por meio do retorno à fundação ou poderiam ser conduzidas à ruína e ao domínio externo. Entretanto, não se pensava em constituir um corpo político inteiramente novo. Os revolucionários, de forma distinta, pensaram e agiram em torno da fundação de uma nova constituição sem precedentes na história. Nesse sentido, fundação passa a significar também a constituição de algo novo. Exemplo disto foi a Revolução NorteAmericana, que, apesar de se referir aos antigos, não tratou de fundar Roma de novo, mas de fundar uma república nunca antes vista na história: uma nova Roma. ${ }^{31}$

A autora aponta que, no século XVIII, os homens não acreditavam mais que as formas constitucionais se repetiam invariavelmente. Eles entenderam que era possível criar uma esfera secular permanente e nova. Diversas inovações já haviam aparecido no mundo moderno, no conhecimento e nas ciências, no trabalho e na produção, de forma que os homens passaram a considerar que a vida política poderia comportar novidades também. ${ }^{32}$

Nesse contexto, a fundação passou a abarcar dois elementos que aparentemente são contraditórios: a novidade e a estabilidade. Fundar se tornou iniciar algo novo a partir da ação humana em concerto, além disso, passou a significar um esforço conjunto de preservar e dar permanência àquilo que surgiu no mundo. ${ }^{33}$ Dito de outra forma, o espírito revolucionário inspira os homens a renovar o mundo e ao mesmo tempo preservá-lo. Segundo Arendt, estes dois elementos podem ser expressos em uma Carta Constitucional que registra e resguarda novos ordenamentos e instituições. Em suas palavras, "Nas condições modernas, o ato de fundação equivale a criar uma Constituição, e a convocação de assembleias constituintes se tornou a justo título a marca própria da revolução [...]" (Sobre a Revolução, p. 283).

\footnotetext{
${ }^{31}$ Conferir em Sobre a Revolução, p. 271.

${ }^{32}$ Ver em Sobre a Revolução, p. 285.

${ }^{33}$ Conferir em Sobre a Revolução, p. 291.
} 
Para a autora, isto ficou claro com a Declaração de Independência NorteAmericana, que rapidamente abriu espaço para a criação de várias assembleias constituintes estaduais, e com o Juramento do Terceiro Estado em manter-se unido até que fosse redigida uma Constituição para a França. Nesta perspectiva, a fundação requer uma espécie de ação que envolve uma pluralidade de pessoas, ela dá origem a um novo corpo político e autoridade, apoia-se no pacto mútuo, une a comunidade política, isto é, associa as pessoas e grupos publicamente e deve inspirar os atos e as gerações futuras a rememorar o início e revigorar seu princípio.

Os eventos revolucionários indicaram um novo sentido de fundação. Por um lado, as revoluções mostraram que era possível criar um corpo político novo por meio da ação em conjunto em apenas alguns anos. Diferentemente de Cícero, para quem muitas gerações estavam envolvidas com a tarefa de constituir uma república, e de Maquiavel, para quem a fundação de uma república poderia ser feita em pouco tempo, mas por meio da ação de um só homem. As revoluções mostraram que a ação em conjunto pode romper em pouco tempo com o curso dos acontecimentos e estabelecer uma nova forma de viver em comunidade, uma nova época.

Além disso, a participação no ato de fundação nunca havia sido tão ampliada: tanto no Novo quanto no Velho Mundo pessoas que antes não eram admitidas no espaço público debateram sobre os princípios revolucionários e agiram para levá-los a cabo. Neste contexto, a liberdade pública foi experimentada em seu mais alto grau: novos corpos políticos foram criados. A ação revolucionária foi inspirada pelo gosto de participar nos assuntos públicos e pela concepção de que o direito de participar no governo deveria ser amplo. Para Bignotto, "Nesse terreno podemos dizer que Arendt estruturou seu pensamento em torno de dois eixos: a questão da Constituição e aquela da dimensão simbólica e imaginária da fundação." ("Hannah Arendt e a Revolução Francesa”, p. 52).

Em contrapartida, ao relacionar fundação e novidade, as revoluções trouxeram novos riscos para a vida política, notadamente, o surgimento do terror. O primeiro risco foi apontado pela autora em sua avaliação sobre a Revolução Francesa. Como já foi discutido, Robespierre promoveu a noção de fundar como fazer. Ele aplicou a categoria de meios e fins à ação fundadora e com isso passou a justificar qualquer meio para atingir a finalidade da revolução. Ao se apoiar na linguagem de Maquiavel, ele entendeu a violência como 
melhor recurso para fazer um novo corpo político e uma nova sociedade. Arendt esclarece esta valorização da violência em $A$ Condição Humana: “[...] até a era moderna esse elemento de violência permaneceu estritamente instrumental, um meio que precisava de um fim que o justificasse e limitasse, de sorte que a glorificação da violência como tal esteve inteiramente ausente do pensamento político até a era moderna" ( $A$ Condição Humana, p. 248).

$\mathrm{Na}$ tentativa de evitar a imprevisibilidade própria da atividade política e garantir que os fins revolucionários fossem atingidos, Robespierre abandonou o debate público, a persuasão e passou a centralizar as decisões e perseguir opositores. Para Arendt, o recurso à violência juntamente com a redução do espaço público-político conduz facilmente à tirania ou ao terror. A partir das concepções deste revolucionário, alguns teóricos passaram a identificar ação revolucionária com violência e fundação com fazer uma sociedade ou comunidade de alto a baixo. Em Sobre a Violência, a autora aponta que a nova esquerda defendia que a violência poderia fazer nascer uma nova sociedade e resolver as questões sociais. Mao Tsé-tung, por exemplo, entendia que "o poder brotava do cano de uma arma", e, quando liderou a China, passou a usar da força das armas para transformar radicalmente o país. ${ }^{34}$

Outro problema que surgiu a partir de interpretações da Revolução Francesa consiste no formalismo constitucional. Alguns teóricos interpretam que as diversas Constituições que se seguiram durante o evento revolucionário indicam que, para ter legitimidade e autoridade, uma Carta Constitucional requer o trabalho de especialistas, que conhecem conjuntos de arranjos institucionais e tecnicalidades. ${ }^{35}$ Ao contrário, Arendt entende que faltou às Constituições criadas na Revolução Francesa, principalmente, apoio público: muitos grupos deixaram de sustentar os princípios que surgiram no início da Revolução Francesa. A primeira Constituição, de 1791, não foi aceita pelo rei nem ratificada pelo povo e a Carta Constitucional girondina não foi apoiada por algumas facções ao ser considerada de difícil implementação prática. Nas palavras de Bignotto,

\footnotetext{
${ }^{34}$ Ver em Sobre a Violência, p. 26.

${ }^{35}$ Aqui mais uma vez podemos colocar Arendt ao lado de Cícero e Maquiavel, uma vez que os dois autores entendem que não basta o conhecimento sem experiência e prática nas atividades da vida política. Nesse sentido, o conhecimento das leis não é garantia para a boa ordenação de uma república, o vigor do corpo político depende do envolvimento dos cidadãos com a coisa pública.
} 
"recheado de minúcia, ele [o projeto constitucional girondino] acabou sendo descartado pelos jacobinos, que aos poucos dominavam a cena política francesa, como um texto incompreensível e inaplicável” (“A Matriz Francesa”, p. 210).

Assim, como indica Arato, Arendt apresenta três formas de constituir um corpo político. A primeira - a constituição formada ao longo de gerações - era inspirada no modelo romano e britânico e já havia sido tratada pela tradição. A segunda consiste em um ato de governo em que alguns especialistas redigem o documento e definem a forma do corpo político. Este tipo de Constituição foi bem comum durante o pós $1^{\mathrm{a}}$ e $2^{\mathrm{a}}$ Guerras Mundiais, e, apesar de promover a transição de um governo autoritário para um governo limitado, impediu a articulação do povo enquanto tal. A terceira forma de criação de Constituição foi mobilizada por Arendt a partir da experiência de criação de assembleias e convenções durante as Revoluções Americana e Francesa. Este último modo de elaboração constitucional é defendido pela autora por envolver amplo debate e participação na criação de instituições livres e novas. ${ }^{36}$

A este respeito, Bignotto ressalta que o livro Sobre a Revolução oferece um contraponto às correntes do pensamento do século $\mathrm{XX}$ que consideram que uma Constituição consiste na escolha racional de princípios e em sua tradução nas instituições. $^{37}$

Nesse sentido, Arendt, ao mostrar a história do conceito de fundação, trata tanto da potência e do risco da ação política na Modernidade como aponta os problemas do pensamento teórico do século XX. Ao retomar Cícero e Maquiavel, ela é capaz de indicar a novidade que as fundações revolucionárias trouxeram. $\mathrm{O}$ ato fundador nos eventos revolucionários envolveu a participação de pessoas que antes estavam sujeitas à dominação e excluídas do espaço público. Além disso, as revoluções mostraram que a criação de um corpo político inédito em apenas poucos anos é possível. A autora também aponta como o pensamento político foi apropriado pelos homens das revoluções com o intuito de garantir que o ato fundador fosse bem sucedido. O elogio das virtudes e das qualidades divinas de um cidadão feitas por Cícero foi distorcido em detrimento da ação dentro das instituições e

\footnotetext{
${ }^{36}$ Sobre estes três tipos de elaboração de Constituição, conferir em Arato, Civil Society, Constitution, and Legitimacy, p. 232 e 240.

${ }^{37}$ Ver em "Hannah Arendt e a Revolução Francesa", p. 44
} 
leis. As concepções de Maquiavel, por sua vez, foram deturpadas de forma a justificar o uso da violência e de medidas extraordinárias por um longo período de tempo. Nesse contexto, para Arendt, o decurso da Revolução Francesa mostra como a ação revolucionária pode degenerar em terror, como a preocupação com a criação de instituições livres e novas pode se perder. Outro risco que surgiu a partir das revoluções do século XVIII foi a valorização das questões técnicas e jurídicas envolvidas na fundação, que promoveram o esvaziamento da atividade política e da participação em favor da ideia de que uma Carta Constitucional deve ser feita por especialistas.

Levando em conta as interpretações de seu tempo acerca dos eventos revolucionários, Arendt afirma que a associação entre revolução, fundação e constituição não está evidente. No entanto, segundo ela, para os revolucionários, era claro que a fundação de um novo corpo político envolvia a elaboração de uma nova Constituição que estabelece limites para o espaço político e define regras para a atuação dentro dele. Além disso, a Constituição também deveria conservar o gosto pela liberdade, o espírito que faz a revolução surgir. ${ }^{38}$

\subsection{Constituição}

A autora afirma que, assim como o conceito de revolução era mal interpretado em seu tempo, o termo constituição também foi mal compreendido pelos seus contemporâneos. Por um lado, constituição foi entendida como resultado da contrarrevolução. Por outro lado, a constituição foi definida como o estabelecimento de um governo limitado por meio da declaração de direitos civis. De acordo com Arendt, estes equívocos a respeito do termo constituição partiram dos diversos levantes revolucionários ao longo dos séculos XIX e XX que não conseguiram estabelecer um novo corpo político baseado na liberdade pública.

A concepção de que constituição significaria uma medida antirrevolucionária se fundamenta nos levantes revolucionários que ocorreram na Europa no período entre guerras e nas antigas colônias europeias que conquistaram independência depois da

\footnotetext{
${ }^{38}$ Conferir em Sobre a Revolução, p. 171.
} 
Segunda Guerra Mundial. Estes levantes revolucionários foram derrotados e, em seguida, foram impostas Constituições a estes povos. ${ }^{39}$ Tais Constituições não foram fruto da revolução, do debate público e da ação em conjunto, ao contrário, foram feitas por especialistas e serviram para deter a onda revolucionária, ou seja, para limitar o poder do povo. Somaram-se a estas experiências as revoluções Russa e Chinesa, as quais se basearam na noção de revolução permanente e abandonaram a tarefa de criar uma nova Constituição. $^{40}$

Já aqueles que definem constituição como o estabelecimento de um governo limitado por meio de declaração de direitos e liberdades civis entendem a revolução como sinônimo de rebelião e revolta. Nesta perspectiva, a revolução consistiria em uma luta de libertação da tirania e, por conseguinte, seu objetivo seria estabelecer salvaguardas contra o governo. ${ }^{41}$ Para a autora, esta interpretação equivocada do significado de constituição não é arbitrária, ela se baseia na experiência inicial das revoluções, as quais começaram com a reivindicação de restauração de antigos direitos em razão do abuso e da arbitrariedade cometida pelos governantes. Mas tal interpretação negligencia que o auge dos levantes revolucionários não se resume à derrubada de um governo autoritário, sobretudo, consiste na constituição de um corpo político baseado na liberdade pública.

Arendt, para argumentar contra a definição de constituição como medida antirrevolucionária, discorre sobre a ambiguidade do termo: ele designa tanto o ato de constituir leis quanto as leis constituídas. Em outras palavras, constituição nomeia o ato de criar novas leis e novas instituições e também se refere ao documento que registra as leis, isto é, à Carta Constitucional. Na perspectiva da autora, não se deve concluir a partir desta ambiguidade que a constituição consiste em um ato de governo. Ao contrário, constituir é o ato do povo que estabelece um corpo político para si. $^{42}$

É importante sublinhar que a autora chama atenção para o fato de que este significado de constituição foi esquecido. A ação do povo de constituir um corpo político foi negligenciada pela teoria política de tal forma que mesmo alguns comentadores de

\footnotetext{
${ }^{39}$ Utilizamos o termo Constituição (com letra maiúscula) para indicar a Carta Constitucional, e o termo constituição (com letra minúscula) para designar o ato de um povo constituir leis e um governo.

${ }^{40}$ Ver em Sobre a Revolução, p. 192.

${ }^{41}$ Conferir em Sobre a Revolução, p.189-191.

${ }^{42}$ A autora se apoia nas seguintes palavras de Thomas Payne: "Uma constituição não é o ato de um governo, e sim de um povo constituindo um governo". Em Sobre a Revolução, p. 193.
} 
Arendt deixaram de tratar os dois sentidos do termo constituição. Waldron, por exemplo, considera que a autora define este termo somente como o conjunto de leis que regulam as instituições políticas. Ele não trata detidamente de seu outro significado: enfatiza a estrutura e as regras que são necessárias para a ação dentro de espaços institucionais, mas não discute o ato de constituir, que se dá, por definição, espontaneamente, fora de instituições e sem normas pré-estabelecidas. Para o comentador, constituir é um ato prépolítico que constrói os muros e cercas que separam o domínio privado do espaço público. Ele leva em consideração somente o sentido grego de lei e a figura do legislador. Ele não leva em conta a concepção de fundação romana, que consiste em uma ação e envolve uma pluralidade de agentes. ${ }^{43}$

No entanto, os dois significados de constituição apresentados por Arendt são importantes e estão relacionados. Já vimos com a discussão sobre o termo fundação que a abertura do espaço público-político tem influência no desenrolar da vida da comunidade, isto é, o princípio de certa forma afeta a comunidade política até o seu fim. Veremos com a discussão acerca do termo constituição que o modo pelo qual uma Carta Constitucional é criada influi na durabilidade, na autoridade e no vigor das instituições. Além disso, os dois sentidos do termo constituição são fundamentais na reflexão sobre as revoluções e sobre a ação a partir da Modernidade.

A íntima ligação entre constituição e ação revolucionária pode ser encontrada ao se olhar para as Revoluções Americana e Francesa: ao mesmo tempo em que lutavam pela independência e pela queda do absolutismo, os revolucionários criaram assembleias constituintes e convenções que visavam redigir um projeto de Carta Constitucional que deveria ser discutido e aprovado pelo povo.

Arendt, a partir da comparação entre as revoluções que estabeleceram uma constituição e os levantes revolucionários que foram derrotados, aponta a diferença entre Constituições feitas pelo povo e aquelas impostas a um povo. Uma constituição revolucionária envolve a ação de muitos e o debate público. A Carta Constitucional que resulta de um ato do povo consiste em "um padrão, um pilar e um vínculo": ${ }^{44}$ estabelece um padrão na medida em que cria instituições e regras para abrigar a atividade política;

\footnotetext{
${ }^{43}$ Conferir sobre Waldron e constituição em "Arendt's Constitutional Politics”, p. 203.

${ }^{44}$ Ver em Sobre a Revolução, p. 194.
} 
torna-se um pilar por conferir estabilidade e durabilidade à vida em comunidade e estabelece um vínculo ao relacionar publicamente as pessoas e grupos. Nesse sentido, a constituição revolucionária surge da confiança no poder e na ação do povo.

Já as Constituições impostas surgiram da desconfiança no poder e do medo da ação do povo, por isso, visavam à limitação da participação e do poder popular. Nestes casos, a ação ampliada é esvaziada em nome da fabricação de leis e instituições, feitas por um ou poucos especialistas que redigem uma Carta Constitucional como se a ela fosse "um pudim que se faz com uma receita". ${ }^{45}$ Nesses casos, o governo e as leis carecem de confiança, poder e autoridade. Nas palavras de Arendt:

"Pois a falta de poder e a concomitante falta de autoridade têm sido a maldição que persegue o governo constitucional em quase todos os países europeus desde a abolição das monarquias absolutas, e as quatorze constituições da França entre 1789 e 1875 fizeram com que a própria palavra se tornasse uma piada, mesmo antes da chuvarada de constituições do pós-guerra no século XX." (Sobre a Revolução, p. 194).

De acordo com a autora, o fim de qualquer evento revolucionário consiste em fundar uma nova constituição. Arendt define, data e avalia o sucesso das revoluções ao analisar como se desenrolou o ato de constituir. Um levante só é considerado revolucionário no pensamento da autora caso vise mais do que a libertação de um governo tirânico ou ilegítimo, caso busque fundar um novo corpo político baseado na liberdade. Tanto na Revolução Americana quanto na Francesa, os homens declararam o gosto pela liberdade e procuraram constituir uma nova estrutura política. Para Arendt, a Revolução Americana durou 13 anos, começou com os debates nos municípios sobre a independência e terminou com a criação da Constituição Federal. O início da Revolução Francesa se deu com a queda da Bastilha, seu desfecho foi longo e difícil de ser datado: começou com o fracasso da Constituição Girondina, em seguida, foram os jacobinos que fracassaram em estabelecer uma Constituição duradoura, por fim, o Reinado do Terror acabou com a atividade política. $^{46}$

Até aqui, é possível identificar alguns critérios que a autora utiliza para avaliar uma Constituição: sua durabilidade, o modo com que ela surgiu - se foi fruto da ação ou produto da fabricação, se foi feita por poucos ou foi instituída pelo povo. Além destes

\footnotetext{
${ }^{45}$ Conferir em Sobre a Revolução, p. 192.

${ }^{46}$ Ver em Sobre a Revolução, p. 110-111.
} 
critérios, Arendt avalia também a novidade que a constituição engendrou. Ora, se a revolução é o fenômeno político que enfrenta a questão do início, toda constituição revolucionária deve estabelecer uma ruptura com a forma política anterior e, consequentemente, fazer surgir no mundo alguma novidade. Neste ponto, ela argumenta contra os teóricos do constitucionalismo que definem constituição como governo limitado. As liberdades civis e os direitos que instituem uma salvaguarda contra os abusos do poder eram anteriores ao século XVIII, não foram fruto da revolução. Ainda, tais direitos promovem libertação, mas não garantem a liberdade pública. Nos termos da autora:

"Se nas revoluções estivesse em jogo apenas esse tipo de constitucionalismo, as revoluções teriam se mantido fiéis a seus modestos inícios, quando ainda podiam ser entendidas como tentativas de restaurar 'antigas' liberdades [liberties]: mas a verdade é que não foi este o caso" (Sobre a Revolução, p. 191).

Nesse sentido, os revolucionários reivindicavam mais do que a limitação do governo, lutavam pela participação no poder. A ideia de que é preciso declarar direitos e liberdades individuais era ponto pacífico entre os homens das revoluções, seus grandes debates giraram em torno de como estabelecer um novo sistema de poder e nova autoridade: "a questão principal para eles certamente não era como limitar o poder, e sim como instaurar um novo" (Sobre a Revolução, p. 196).

De acordo com Arendt, o equívoco de definir o ato de constituir em termos de limitação do governo se deve ao importante papel que a "Declaração Universal dos Direitos do Homem e do Cidadão" desempenhou na Revolução Francesa. A centralidade desta declaração reside no fato de que ela deveria ser a base do novo sistema de poder, não consistia na limitação do governo, mas nos marcos que fundariam o novo governo. ${ }^{47}$ No entanto, como os revolucionários franceses não estabeleceram uma Constituição duradoura, estes direitos não foram vistos como fundamento de um novo poder.

No que tange à durabilidade e estabilidade da Constituição, a Revolução Americana foi bem sucedida, por isso, para Arendt, a revolução no Novo Mundo revela o novo e verdadeiro significado do termo "constituição", enquanto que a revolução no Velho Mundo indica as dificuldades e perplexidades com que os homens se deparam ao lidar com a questão do início.

\footnotetext{
${ }^{47}$ Conferir em Sobre a Revolução, p. 196.
} 
Para Arendt, os revolucionários recorreram às experiências antigas e ao que eles chamavam de "ciência política" para auxiliar a ação de constituir um novo poder. Nas suas palavras:

"Cientes de sua ignorância sobre o assunto, eles recorreram à história, reunindo com uma minúcia que beirava o formalismo todos os exemplos, antigos e modernos, reais e fictícios, de constituições republicanas; o que procuravam aprender não era de maneira alguma a salvaguarda das liberdades civis - tema sobre o qual certamente sabiam muito mais do que qualquer república anterior e sim a constituição do poder" (Sobre a Revolução, p. 198).

No caso norte-americano, onde assembleias municipais e estaduais criaram diversos centros de poder, os revolucionários se apoiaram no pensamento de Montesquieu e na tradição do governo misto para conceber um novo sistema de poder. Esta noção de sistema de poder se baseia na ideia de que existem diversos centros de poderes paralelos, que não se excluem entre si na medida em que podem ser combinados e equilibrados. $\mathrm{Na}$ perspectiva da autora, a inovação que a Constituição Norte-Americana fez surgir no mundo foi justamente esta concepção de sistema de poderes que não se baseia na centralização nem na noção de soberania:

"Neste aspecto, a grande - e a longo prazo talvez a maior - inovação americana na política como tal foi a abolição sistemática da soberania dentro do corpo político da república, a percepção de que, na esfera dos assuntos humanos, soberania e tirania se equivalem" (Sobre a Revolução, p. 202).

A concepção de que seria prudente criar diversos centros de poder está baseada em duas noções, a saber, a concepção de que o poder vem do povo e o reconhecimento de que o povo é plural. O ideário político francês também entendia o povo como a fonte do poder, entretanto, a concepção de povo foi borrada pela concepção de nação. A "Declaração Universal dos Direitos do Homem e do Cidadão", na passagem "todos os homens nascem iguais", vincula direitos com um dado biológico - o nascimento. Segundo Arendt, isto gerou duas consequências: primeiro, afastou a concepção de direito como algo artificial, criado por uma comunidade política e, segundo, possibilitou que o povo fosse visto como massa homogênea na medida em que ele se tornou nação, isto é, um grupo de pessoas com o mesmo nascimento. ${ }^{48}$ Nesse contexto, em que os homens passaram a ser vistos como iguais por nascimento, a ideia de criar diferentes centros de poderes e diversas instituições

\footnotetext{
${ }^{48}$ Ver em Sobre a Revolução, p. 196-197.
} 
perdeu força em prol da noção de centralização. Afinal, se a nação tem uma única vontade, pode ser representada por uma única instituição.

Como foi tratado no capítulo anterior, segundo Arendt, a nação foi relacionada com as concepções de soberania e vontade e isto tornou quase impossível a tarefa de estabelecer uma Constituição duradoura. Estas concepções foram engendradas na tentativa de dar respostas ao problema do início de um novo corpo político e do estabelecimento de uma nova autoridade. $\mathrm{O}$ início precisa ter um fundamento para que não seja entendido como arbitrário e as leis civis necessitam de uma autoridade que lhes confira legitimidade. Para fundamentar a república e dotá-la de autoridade, os revolucionários franceses buscaram uma fonte transcendente e absoluta para o poder e para a lei. De acordo com a autora, no absolutismo, a fonte da lei e do poder era divina, localizava-se fora e acima do corpo político: a teoria da origem divina dos reis fundamentou a monarquia e suas leis. De forma análoga, pareceu aos revolucionários franceses razoável colocar a nação como um absoluto, anterior e acima das leis.

A Revolução Norte-Americana, ao contrário, pôde estabelecer uma Constituição duradoura ao derivar a legitimidade das leis do ato de constituir.

"Para eles [revolucionários norte-americanos], a sede do poder era o povo, mas a fonte da lei viria a ser a Constituição, um documento escrito, uma coisa objetiva duradoura, que certamente podia ser abordada por muitos ângulos diferentes e interpretada de muitas maneiras diversas, que podia ser modificada e emendada de acordo com as circunstâncias, mas que mesmo assim jamais era um estado de espírito subjetivo como a vontade" (Sobre a Revolução, p. 207).

Teoricamente falando, a ideia de poder e de constituição de um governo tem sido estruturada com base em dois tipos diferentes de teorias do contrato social. De acordo com Arendt, no século XVII existiam dois tipos de "contrato social" [social contract], um que era firmado entre indivíduos e dava origem à sociedade ou a uma comunidade, e outro que era firmado entre o povo e seu governante e resultava em um governo legítimo. Contudo, as diferenças entre estes dois tipos de contrato foram apagadas quando a filosofia política tentou encontrar uma teoria universal que explicasse tanto a origem da sociedade quanto do governo, ou seja, uma teoria que tratasse ao mesmo tempo das relações sociais e 
políticas. A autora enfatiza que estes dois tipos de contratos sociais não são apenas diferentes, mas excludentes. ${ }^{49}$

O primeiro tipo de contrato, no qual as pessoas se unem para formar uma comunidade, é baseado na reciprocidade e na igualdade, seu conteúdo é a promessa mútua. Ele faz surgir uma aliança pública entre os homens e gera poder, o qual se assenta na confiança mútua e na ação de muitos em conjunto. Já o segundo contrato é baseado em uma assimetria entre os membros da sociedade e seu governante: cada um abre mão de sua força para estabelecer um governo. Neste caso, os indivíduos não se associam publicamente, eles permanecem no espaço privado e, longe de ganharem poder, renunciam a ele. O poder, nesse segundo tipo de contrato, está nas mãos dos governantes, não do povo, e se assenta no consentimento, não na ação em conjunto. Nas palavras da autora: “[...] os que 'pactuam e se combinam' perdem, em virtude da reciprocidade, seu isolamento inicial, ao passo que, no outro caso, é exatamente esse isolamento que é protegido e resguardado" (Sobre a Revolução, p. 223).

Levando em conta estes dois tipos de contrato, fica claro que o poder, por um lado, pode ser entendido como algo que surge da associação entre os homens e se sustenta na participação nos assuntos públicos e, por outro, o poder pode ser entendido como dominação, seu fundamento está na divisão entre aqueles que ordenam e aqueles que obedecem e executam ordens.

Arendt defende a concepção de poder como ação em conjunto e relaciona o ato de constituir uma nova estrutura política com a noção de contrato mútuo. Para ela, a promessa mútua foi a base da experiência revolucionária norte-americana. Ao contrário das teorias do contrato que estabelecem um governo, o contrato mútuo não é uma ficção, um momento imaginário. O Pacto de Mayflower foi um exemplo de promessa mútua, nele os colonizadores fizeram uma aliança: "solenemente e mutuamente na presença de Deus e uns dos outros, pactuar e nos reunir em um corpo civil [...]; e, em virtude deste aprovar, constituir e dispor leis, ordenações, decretos, constituições e cargos justos e iguais [...]" (Sobre a Revolução, p. 225).

Segundo a autora, os colonizadores, quando saíram do Velho Mundo em direção a um lugar desconhecido, onde não havia regras e costumes pré-estabelecidos, decidiram

\footnotetext{
${ }^{49}$ Nesta passagem, Arendt dialoga com Locke e Hobbes. Conferir em Sobre a Revolução, p. 221.
} 
evitar as incertezas e refrear os excessos que os homens podem cometer por meio de pactos e obrigações mútuas. Dessa forma, cada um dos colonizadores dava garantia aos outros de que a convivência na colônia seria civilizada e auto-organizada. ${ }^{50}$

Por meio destes pactos e alianças, os homens no Novo Mundo descobriram a gramática da ação, atividade que exige pluralidade, a associação de uma multiplicidade de agentes; e descobriram a sintaxe do poder, o qual se localiza no entremeio mundano, no espaço compartilhado pelos homens. Na revolução, os norte-americanos se basearam nesta experiência anterior de fazer alianças e, a partir dos corpos civis constituídos no período colonial, do debate nos municípios e da ação em conjunto, constituíram um novo corpo político. A partir das promessas e pactos mútuos, os homens do Novo Mundo redescobriram o princípio republicano e criaram o princípio federativo, que combina diferentes centros de poder sem mudar a identidade de cada um.

Assim, na perspectiva arendtiana, o poder nasce somente quando os homens se unem para agir em conjunto, ele só pode ser mantido se os homens pactuam entre si e prometem manter a aliança uns com os outros. Para a autora, sempre que os homens conseguem preservar o poder nascido no espaço público já está em curso o ato de fundação. Na medida em que fundação, no pensamento de Arendt, significa abrir e preservar um espaço público-político, também implica fazer e manter promessas. As promessas tratam do futuro, da continuidade de uma comunidade política, uma vez que oferecem "estabilidade no oceano de incertezas". Em suas palavras: "A faculdade humana de fazer e manter promessas guarda um elemento da capacidade humana de construir o mundo." (Sobre a Revolução, p. 228).

Nesse sentido, a partir das Revoluções Americana e Francesa, Arendt demonstra o novo significado de constituição: o ato de um povo que funda um novo corpo político. A Carta Constitucional tem o papel de registrar o pacto que liga os concidadãos, o sistema de poderes constituído pelo povo e as regras da convivência pública. A autora defende que o fim da revolução é a constituição da liberdade, apesar de muitos levantes revolucionários no século XX terem sido vencidos e apesar das teorias relacionarem constituição com contrarrevolução ou com governo limitado.

\footnotetext{
${ }^{50}$ Ver em Sobre a Revolução, p. 227.
} 
Para Arendt, o fato de um levante revolucionário ter fracassado não invalida sua importância como experiência revolucionária nem altera o significado de constituição. Isto fica claro com sua interpretação da Revolução Francesa. Embora os franceses não tenham sido bem sucedidos na tarefa de estabelecer uma Constituição duradoura, a criação da Assembleia Nacional, dos clubes e sociedades indica a íntima relação entre revolução e constituição de um corpo político livre. Além disso, o desfecho deste evento cristaliza os problemas enfrentados pelos homens ao tentar iniciar algo novo, ao tentar estabelecer um novo poder e uma nova autoridade. Por isso, este evento não foi desconsiderado no pensamento da autora.

\subsection{A fundação do novo: os conselhos revolucionários}

De acordo com Arendt, por mais que um levante revolucionário tenha como objetivo fundar um corpo político novo onde a liberdade possa aparecer, o desenrolar da ação nunca é completamente previsível e determinado. Por isso, uma revolução pode acabar de diversas maneiras: com a fundação de uma república, com o estabelecimento de um governo limitado, com o reestabelecimento do regime precedente, ou com a degeneração em tirania e terror. ${ }^{51}$

Apesar das experiências malfadadas, Arendt afirma que uma Constituição revolucionária deve estabelecer uma república capaz de preservar o espírito que a fez surgir. Em outras palavras, algum espaço deve ser destinado ao exercício das práticas públicas que deram início à revolução. A autora enfatiza isso, pois, para ela, nem mesmo a tradição revolucionária resguardou este espírito e a grande novidade que surgiram nas revoluções. Conforme a autora, as teorias dedicadas ao estudo destas experiências são de origem europeia e elas guardam pouco interesse pelo evento revolucionário no Novo Mundo. ${ }^{52}$ Em suas palavras:

\footnotetext{
${ }^{51}$ Conferir em Sobre a Revolução, p. 294. Vimos recentemente com a Primavera Árabe que, de fato, a reinvindicação por liberdade e os levantes revolucionários nem sempre são bem sucedidos: no Egito, o levante popular foi seguido por intervenção militar e ditadura; na Síria, acabou em guerra civil; apenas na Tunísia um governo livre foi fundado.

${ }^{52}$ No tempo de Arendt, as Revoluções Francesa, Russa e Chinesa eram as mais citadas e valorizadas. Ver em Sobre a Revolução, p. 276.
} 
“[...] o pensamento político revolucionário dos séculos XIX e XX se conduziu como se nunca tivesse ocorrido uma revolução no Novo Mundo e como se nunca tivesse surgido nenhuma noção ou experiência americana na esfera política e do governo merecedora de alguma reflexão" (Sobre a Revolução, p. 275).

Nos Estados Unidos, além da experiência revolucionária não ter sido resguardada por meio da teoria política, o discurso antirrevolucionário norte-americano que surgiu no século XX procura apagar o fato de que uma revolução fez surgir a República federada no país e ainda reforça a concepção consagrada pela tradição revolucionária de que, para pensar em revolução, é preciso usar os termos da Revolução Francesa.

No contexto político e teórico em que Arendt vivia, os princípios mais caros aos homens das revoluções setecentistas - a liberdade pública e a participação política - eram negligenciados tanto pela tradição liberal quanto pela revolucionária. De um lado, liberdade passou a ser entendida como livre-iniciativa. No entanto, para a autora, somente nos EUA a livre-iniciativa e o capitalismo têm levado ao bem estar individual, em outros países eles têm levado frequentemente à infelicidade e à pobreza em massa. ${ }^{53}$ Do ponto de vista liberal, a fundação da república norte-americana parece ter sido feita somente em nome das liberdades civis, do bem-estar individual da maioria. De outro lado, a tradição revolucionária transformou os princípios políticos em valores sociais: a isonomia para agir e discursar se tornou igualdade de condição, a liberdade se tornou liberação da necessidade. Além disso, as reivindicações estritamente políticas que surgiram nas revoluções foram taxadas de preconceitos pequeno-burgueses por não colocarem em primeiro plano a urgência das questões sociais. ${ }^{54}$ Nesse sentido, para Arendt, nenhuma teoria política preservou o espírito da revolução, isto é, os princípios de liberdade e felicidade pública que fizeram com que os homens se engajassem na ação revolucionária.

De acordo com a autora, “A falha do pensamento pós-revolucionário em lembrar o espírito revolucionário e entendê-lo conceitualmente foi precedida pela falha da revolução em lhe fornecer uma instituição duradoura" (Sobre a Revolução, p. 293). Na perspectiva arendtiana, para entender o fracasso das revoluções em instituir um espaço destinado à liberdade, é preciso olhar para a emergência de órgãos populares nas Revoluções NorteAmericana e Francesa.

\footnotetext{
${ }^{53}$ Ver em Sobre a Revolução, p. 277.

${ }^{54}$ Conferir em Sobre a Revolução, p. 281.
} 
Ao buscar o modo pelo qual o povo se constituiu e agiu para colocar em movimento estas duas revoluções, Arendt identifica que elas não foram preparadas e guiadas por um determinado grupo, líder ou plano político. Os eventos revolucionários irromperam com a formação espontânea de órgãos populares reservados ao debate público e à ação. Estes órgãos se articularam e, com isso, os revolucionários foram capazes de coordenar ações em todo território colonial e francês. A autora denomina esta articulação de órgãos populares de sistema de conselhos. Este sistema foi capaz de derrubar o domínio inglês no Novo Mundo e o domínio absolutista na França e de gerar um novo poder. A partir dos órgãos populares era possível que cada um participasse dos assuntos públicos, era possível fundar um novo corpo político onde a liberdade política fosse uma experiência tangível.

Segundo Starling, o que Arendt chama de sistema de conselhos surgiu na América do Norte como uma resistência coordenada contra as políticas coloniais inglesas. A historiadora aponta que diversos grupos sociais criaram espontaneamente associações e sociedades políticas que se articularam em rede por meio de petições e declarações para coordenar ações em várias partes da colônia. Em suas palavras, “[...] uma grande variedade de organizações muito ativas que se desenvolveram sustentadas por uma estrutura associativa, inteiramente independente umas das outras e intensamente envolvidas em processos colaborativos" (“A Matriz Norte-Americana”, p. 241).

Arendt assevera que os pais fundadores, com exceção de Jefferson, não viram a importância do papel destas associações e das municipalidades para a revolução e para a política. Por isso, falharam em institucionalizá-las e articulá-las com os outros centros de poder, como as instâncias estaduais e federal. A máquina administrativa estadual e da união não permitiu a participação ampliada, comportou apenas os representantes do povo. Por esta razão, a república dos Estados Unidos careceu de órgãos concretos para a ação dos cidadãos. ${ }^{55}$

Jefferson foi o único que percebeu que os distritos eram os espaços onde a voz do povo podia ser ouvida: era o lugar de troca e formação de opiniões que revigorava e renovava a vida política. De acordo com a autora, este pai fundador constatou isso quando já estava afastado das atividades públicas e de alguma forma compreendeu que havia uma

\footnotetext{
${ }^{55}$ Ver em Sobre a Revolução, p. 298.
} 
grande diferença entre o engajamento popular nos anos da revolução e seu engajamento depois de estabelecida a república. Nesse contexto, Jefferson passou a defender um sistema distrital [ward system] que visava a permitir que cada um tomasse parte do poder cotidianamente e não apenas no dia das eleições. O sistema distrital seria o fundamento de uma vida republicana consistente capaz de evitar tanto o despotismo eletivo quanto uma tirania da maioria. ${ }^{56}$

No último artigo do livro Crises da República, a autora afirma que a participação em eleições por meio de voto é insuficiente. O povo elege representantes, mas não delibera sobre os assuntos públicos. Além disso, é impossível reunir todos os cidadãos de um país em um só lugar, é preciso um certo número de espaços públicos que acolham o debate e a troca de opiniões. Só assim os cidadãos podem escolher seu próprio destino. Em suas palavras,

\begin{abstract}
“As cabines em que depositamos as cédulas são, sem sombra de dúvidas, muito pequenas, pois só tem lugar para um. Os partidos são completamente impróprios; lá somos, quase todos nós, nada mais do que eleitorado manipulado. Mas se apenas dez de nós estivermos sentados em volta de uma mesa, cada um expressando sua opinião, cada um ouvindo a opinião dos outros, então uma formação racional de opinião pode ter lugar através da troca de opiniões" (Crises da República, p. 200).
\end{abstract}

Nessa perspectiva, uma verdadeira república está fundamentada na divisão de poderes e na criação de espaços onde cada um pode atuar no governo comum. A falha em inscrever os distritos na Constituição Norte-Americana comprometeu a participação e a liberdade pública.

Arendt também trata do sistema de conselhos na França. Segundo ela, este sistema surgiu a partir das 48 seções da Comuna de Paris que foram estabelecidas primeiramente para eleger delegados para a Assembleia Nacional. Em pouco tempo estes órgãos abandonaram a preocupação com a representação e se dedicaram ao debate e à ação. Além da comuna, clubes e sociedades populares foram formados por todo o território francês. ${ }^{57}$ Nesse contexto, para a autora, estes espaços surgiram em reposta à restrição do mundo público promovida pelo absolutismo: não havia antes espaços onde o povo poderia se informar e debater sobre os assuntos comuns.

\footnotetext{
${ }^{56}$ Conferir em Sobre a Revolução, p. 315 e 319.

${ }^{57}$ Conferir em Sobre a Revolução, p. 302.
} 
Estes órgãos populares que se formaram espontaneamente eram plurais. Alguns eram formados por representantes e tratavam sobre as pautas das sessões dos Estados Gerais e posteriormente da Assembleia Nacional, como o clube Jacobino e o clube Bretão. Outros se dedicaram a discutir, peticionar e enviar propostas para outras instituições com o intuito de influenciar o debate nacional. Dentre estes, uns procuraram pressionar a Assembleia Nacional: era o caso dos grupos de sans-culottes. Outros órgãos populares buscaram apenas discutir e instruir seus membros acerca dos principais assuntos políticos.

A autora enfatiza que estes órgãos populares, embora vez ou outra tenham se prestado à eleição de representantes e a pressionar o governo, primordialmente, destinavam-se a possibilitar a participação ampliada nos assuntos públicos. Em suas palavras, "Foi este sistema de conselhos comunais, e não de assembleias de eleitores, que se propagou sob a forma de sociedades revolucionárias por toda a França" (Sobre a Revolução, p. 310).

Para ela, estes órgãos populares eram responsáveis por preservar o espírito público, constituíam a própria fundação da liberdade na medida em que tornavam possível o debate e a participação de qualquer um disposto a se dedicar à vida pública.

Contudo, estes órgãos que resguardavam o espírito revolucionário e a liberdade no sentido público passaram a ser perseguidos, principalmente a partir de 1793. Robespierre, que em 1791 defendera as sociedades populares, quando se tornou chefe de governo, passou a combatê-las. Saint Just também defendeu a perseguição das sociedades e, ao afirmar que a liberdade residia na vida privada, emitiu uma sentença contra a participação nos assuntos públicos por meio de órgãos populares. ${ }^{58}$

De acordo com Arendt, a Comuna de Paris e as sociedades populares eram ao mesmo tempo um novo tipo de organização política e poderosos grupos de pressão que, por vezes, colocavam o governo revolucionário em situações delicadas. Estes são dois dos motivos pelos quais os jacobinos transformaram os órgãos populares em instrumentos de governo e do terror. Em outras palavras, para que a Assembleia Nacional fosse soberana, os clubes e sociedades deveriam promover consenso com relação ao que havia sido decidido neste órgão de representação, divulgando as decisões da Assembleia, vigiando os cidadãos e perseguindo os dissidentes. A atuação dos órgãos populares não estava bem

\footnotetext{
${ }^{58}$ Conferir em Sobre a Revolução, p. 303 e 306.
} 
articulada com a atuação da Assembleia Nacional e, por isso, colocava em risco o poder soberano e a autoridade desta instituição.

Arendt chama a atenção aqui para a inversão que Robespierre e os jacobinos promoveram na concepção de Rousseau: para este autor, as discordâncias entre o povo e o governo devem ser eliminadas, pois o governo deve seguir a vontade geral; os jacobinos, ao contrário, quando se depararam com a diferença entre seu programa e o povo, passaram a perseguir os órgãos populares. ${ }^{59}$

Além disso, a Assembleia Nacional encontrava-se dividida em facções, o que por vezes dificultou decisões e a atuação do governo. Conforme a autora, como nenhum partido tinha poder suficiente para dominar as demais facções parlamentares, o modo mais eficaz para facilitar a definição e a implementação de políticas era organizar uma pressão externa para assumir o controle dentro da Assembleia Nacional. Assim, as sociedades foram invadidas pelo discurso jacobino, que visava a divulgar seu programa partidário e a convencer os cidadãos de que este era o partido verdadeiramente revolucionário e que a filiação a esta facção garantiria que a revolução fosse levada a cabo. Para Arendt, quando o debate livre dentro de clubes e sociedades populares foi abandonado em prol da divulgação de discursos vindos de cima e que exigiam obediência, muitos deixaram de aparecer, isto é, a imposição de um discurso provocou o esvaziamento do espaço público.

De acordo com o pensamento da autora, o espaço político tem como característica a pluralidade de pontos de vista e a existência de coisas que são compartilhadas. Nesse sentido, a imposição de um único ponto de vista acaba com a política, empobrece o espaço público e ataca aquilo que é comum a todos.

Para a autora, este método empregado pelos jacobinos para subordinar os órgãos populares aos seus interesses foi usado posteriormente em outras revoluções que tomaram o curso da Revolução Francesa como modelo.

Na Rússia, tanto em 1905 quanto em 1917, por toda parte surgiram conselhos de soldados, operários e camponeses que, em apenas algumas semanas, articularam-se para formar conselhos regionais e um conselho nacional. Arendt afirma que Lênin elogiou a criatividade e a ação do povo na primeira revolução, entretanto não incluiu a organização política dos conselhos na tradição revolucionária, não conciliou estes órgãos populares

\footnotetext{
${ }^{59}$ Ver em Sobre a Revolução, p. 304.
} 
com o pensamento marxista ou mesmo com o programa de seu partido.$^{60}$ Ele continuou a usar a fórmula da ditadura do proletariado e a entender o partido como vanguarda revolucionária. Lênin, ao tomar como modelo o curso da Revolução Francesa, entendeu os conselhos como órgãos temporários na revolução. Assim, de acordo com a autora, no início da revolução de 1917, ele apoiou a ação dos sovietes. Mas, quando estes órgãos populares se rebelaram contra a ditadura do partido único, Lênin defendeu seu partido e passou a atacar estes órgãos, pois não compreendeu que os conselhos poderiam levar adiante a revolução e se tornar um novo sistema de poder.

Segundo Arendt, os sovietes se ocupavam mais com os aspectos políticos da revolução do que o partido revolucionário, que se preocupava excessivamente com as questões sociais. Para que o governo revolucionário se concentrasse na tarefa de construir uma nova sociedade, isto é, para implementar facilmente o programa do partido Bolchevique - que envolvia medidas econômicas de equalização social - era preciso esvaziar os espaços de debate e ação criados pelo povo. Sem o longo processo de troca de opiniões e deliberação ampliada, as medidas do governo revolucionário podiam ser mais rapidamente executadas.

Nesta perspectiva, o partido Bolchevique acabou com o espírito público e substituiu a máquina do Estado pelo aparato do partido. Arendt adota aqui a crítica de Rosa Luxemburgo, segundo a qual a pretensão do partido Bolchevique de se tornar o único existente iria tornar vazia e sem sentido as eleições, os debates públicos e as instituições. "Do ponto de vista de vanguarda de uma verdadeira república soviética, o Partido Bolchevique era apenas mais perigoso, mas não menos reacionário do que todos os outros partidos do regime defunto" (Sobre a Revolução, p. 332). Para Arendt, o partido Bolchevique, por mais que prezasse a revolução, estava apegado às velhas formas de governo e, por isso, não entendeu nem apoiou o novo modo de articulação política e de poder que surgiu com os sovietes.

A autora também trata do levante revolucionário que ocorreu em 1956 na Hungria, quando este país estava sob domínio russo. Mais uma vez, o sistema de conselhos emergiu:

\footnotetext{
${ }^{60}$ Conferir em Sobre a Revolução, p. 323.
} 
foram organizados conselhos de moradores de bairros, de escritores, artistas, estudantes, operários entre outros. ${ }^{61}$ Novamente o partido Bolchevique combateu os órgãos populares.

Conforme a autora, a Revolução Húngara foi iniciada com uma passeata pacífica e inofensiva de poucos estudantes, mas em pouco tempo atraiu uma multidão. No dia seguinte à passeata, os estudantes se dirigiram à radio com o intuito de transmitir um manifesto com dezesseis reivindicações. A polícia tentou dispersar a multidão. Em reposta, o povo se manifestou, e assim começou a revolução. Trabalhadores deixaram as fábricas e foram para as ruas, o exército húngaro não só se recusou a defender o regime, como parte dele armou o povo. As armas da polícia foram tomadas. Em menos de vinte e quatro horas a manifestação pacífica se tornou um levante armado. Os dezesseis pontos do manifesto estudantil foram abandonados e as demandas passaram a ser libertação do domínio russo e o estabelecimento de um novo governo. Em outras palavras, o povo húngaro reivindicava que o exército da União Soviética ${ }^{62}$ deveria se retirar da Hungria e que eleições livres deveriam ser convocadas.

A partir da repressão de um protesto estudantil, o povo se articulou e passou a defender duas bandeiras: liberdade e verdade. ${ }^{63}$ Enquanto a liberdade dizia respeito ao direito de tomar parte nos assuntos comuns, a verdade consistia em combater a ideologia soviética e em denunciar a ditadura totalitária que dominava os países satélites. Para Arendt, o clima de fraternidade que surgiu entre o povo, sem fanatismos, indicou que a doutrinação ideológica fora desintegrada.

"Foi como se ideologia, de qualquer tom e qualidade, tivesse simplesmente sido limpada da existência e da memória no momento que o povo, intelectuais e trabalhadores, comunistas e não comunistas, encontraram-se juntos na rua

\footnotetext{
${ }^{61}$ Ver em Sobre a Revolução, p. 334.

${ }^{62}$ É importante salientar que Arendt critica o uso do termo "União Soviética", pois se trata de um termo que visa a falsear a realidade: o bloco soviético não foi uma união de órgãos políticos livres, mas unido pela força da polícia totalitária e do exército russo. Além disso, não havia nada de soviético, uma vez que os sovietes, conselhos populares, foram aniquilados.

${ }^{63}$ Conferir em "Totalitarian Imperialism: Reflections on the Hungarian Revolution", p. 23-25. "A voz do Leste Europeu, falando muito francamente e simplesmente de liberdade e verdade, soou como uma última confirmação de que a natureza humana é imutável, que o niilismo será inútil, que mesmo na ausência de todo ensinamento e na presença de esmagadora doutrinação o anseio por liberdade e verdade irá surgir do coração e da mente dos homens sempre". No original: "The voice from Eastern Europe, speaking so plainly and simply of freedom and truth, sounded like an ultimate affirmation that human nature is unchangeable, that nihilism will be futile, that even in the absence of all teaching and the presence of overwhelming indoctrination a yearning for freedom and truth will rise out of man's heart an mind forever".
} 
lutando pela liberdade" ("Totalitarian Imperialism: Reflections on the Hungarian Revolution", p. 27). ${ }^{64}$

Quando os diversos agentes puderam agir em conjunto e trocar opiniões plurais, a liberdade pública tinha se tornado realidade, faltava apenas resguardá-la em uma nova constituição política. Nas palavras de Arendt, “A questão não era mais quanta liberdade permitir para a ação, o discurso e o pensamento, mas como institucionalizar uma liberdade que já era um fato realizado" ("Totalitarian Imperialism: Reflections on the Hungarian Revolution", p. 26). ${ }^{65}$

A autora afirma que a revolução na Hungria surpreendeu a todos. Assim como as demais revoluções, foi espontânea, não foi preparada por um grupo ou partido. Principalmente surpreendeu aqueles que pensavam que um levante do povo sem lideranças e sem programa formulado previamente levaria fatalmente ao caos e à desordem. Ao contrário, os conselhos conseguiram manter a civilidade mesmo com o padrão de vida ruim da maior parte da população: saques e invasões de propriedades não ocorreram e a violência foi usada somente quando a polícia tentou reprimir as manifestações populares. ${ }^{66}$

Para Arendt, a constituição de conselhos na Hungria foi o primeiro passo para instaurar uma nova ordem e reorganizar a economia de forma socialista, sem centralização, controle e a violência de um partido. Os conselhos tinham então duas tarefas, uma política e outra econômica. O conselho revolucionário era encarregado das questões políticas e o de trabalhadores das questões econômicas. A autora indica que esta linha divisória entre duas esferas era promissora. Contudo, ela não se dedicou ao estudo dos conselhos responsáveis por gerir a economia, além disso, levando em conta que esta experiência durou pouco, apenas algumas semanas, não foi possível fazer mais do que uma imagem superficial de suas potencialidades e fisionomia.

O exército russo invadiu a Hungria e precisou de três semanas para reprimir esta revolução. A estratégia usada pelas forças armadas russas foi de atacar em primeiro lugar o poder político, isto é, os conselhos revolucionários. Somente num segundo momento a

\footnotetext{
${ }^{64}$ No original: "It was as though ideology, of whatever shade or brand, had simply been wiped out of existence and memory the moment the people, intellectuals and workers, communists and non-communists, found themselves together in the streets fighting for freedom".

${ }^{65}$ No original: "The question was no longer how much freedom to permit to action, speech and thought, but how to institutionalize a freedom which was already an accomplished fact".

${ }^{66}$ Conferir em "Totalitarian Imperialism: Reflections on the Hungarian Revolution", p. 28.
} 
violência foi usada contra as forças produtivas: os conselhos operários e as organizações camponesas. Segundo Arendt, a ordem de aniquilamento dos conselhos mostra que a liberdade de ação foi considerada mais perigosa para a dominação total que imperava no bloco soviético do que as questões sociais ou produtivas. ${ }^{67}$

Como foi exposto acima, o sistema de conselho foi derrotado. Nos Estados Unidos, a falta de institucionalização do sistema distrital e a busca pela riqueza e bem estar individual desestimularam o associativismo civil; as comunas, clubes e sociedades populares na França foram invadidos e dominados pelos jacobinos; os sovietes, derrotados pelo partido Bolchevique e os conselhos na Hungria foram massacrados pelo exército russo. Apesar disso, a autora chama a atenção para o aparecimento insistente desta forma de organização política desde o século XVIII. O sistema de conselhos surgiu em diversos levantes populares: na Revolução Americana, na Revolução Francesa, nas Revoluções Russa de 1905 e 1917, na Revolução Húngara e também na Comuna de Paris de 1871; e em 1918 e 1919 na Alemanha. ${ }^{68}$ Este sistema aponta para uma nova forma de organização política que reinventa a experiência de democracia direta grega e a experiência republicana romana.

Para Arendt, o surgimento e a articulação destes órgãos populares foram espontâneos, impulsionados somente pelo gosto e desejo de liberdade. O sistema de conselhos não foi consequência de forças sociais ou de uma tendência histórica, não foi dirigido por um órgão centralizado ou previsto por alguma teoria revolucionária.

"É precisamente por causa da falta de continuidade, de tradição e de influência organizada que o fenômeno é tão impressionante. Entre as características comuns aos conselhos, a mais destacada, é claro, a espontaneidade com que surgem, pois ela contraria de maneira mais flagrante e evidente 'o modelo [teórico] de revolução do século XX - planejada, preparada e executada com frieza e precisão quase científica pelos revolucionários profissionais"” (Sobre a Revolução, p. 329).

Todas as revoluções genuínas contaram com conselhos que foram formados espontaneamente e que se coordenaram uns com os outros. Tais órgãos, de acordo com Arendt, foram negligenciados por historiadores, pensadores políticos e pela tradição revolucionária. Até mesmo os teóricos favoráveis às revoluções entenderam os sistemas de

\footnotetext{
${ }^{67}$ Ver em "Totalitarian Imperialism: Reflections on the Hungarian Revolution", p. 33.

${ }^{68}$ Conferir em Sobre a Revolução, p. 328.
} 
conselhos como organizações passageiras que auxiliavam somente na luta pela libertação. Marx e Lênin teriam sido os únicos a tratar do assunto, o primeiro autor ao comentar a Comuna de Paris de 1871 e o segundo ao refletir sobre o levante revolucionário russo de 1905. No entanto, a teoria que eles mobilizam para pensar o mundo se baseia na concepção de tendência histórica e aponta que os oprimidos devem tomar o poder, ocupar o Estado para estabelecer uma sociedade sem classes. Quando os conselhos surgiram diante de seus olhos e desmontaram o aparato estatal, eles não interpretaram as ações nestes órgãos como a criação de um novo poder, uma nova forma de organização política, isto é, eles não abandonaram a ideia de "ditadura do proletariado". Nesse sentido, os dois autores se mostraram impressionados com a capacidade do povo em derrubar as velhas formas de dominação, mas não prestaram atenção à nova forma de poder que estava em germe no sistema de conselhos.

Conforme Arendt, ao argumentar em termos de telos e precedentes históricos, a tradição revolucionária e os revolucionários profissionais concluíram que o caminho da Revolução Francesa devia ser seguido: depois que as organizações populares agem para derrubar o velho poder, o partido mais radical deve assumir os rumos da revolução para fazer nascer uma sociedade igualitária.

Sem compreender o novo poder que o sistema de conselhos formava, muitos revolucionários profissionais se opuseram a estes órgãos em favor de algo que repunha os moldes do defunto poder - um Estado centralizado e hierarquizado. Este tipo de revolucionário, embora almejasse mudar a forma de viver em comunidade, não apoiava os conselhos, pois defendia teorias e ideologias ligadas à antiga forma de poder e à associação política por meio de partidos.

Contudo, na perspectiva arendtiana, os conselhos revolucionários constituíram o verdadeiro espaço da liberdade nas revoluções e apontaram para uma nova forma de organização política. ${ }^{69}$ Estes órgãos populares ofereceram a todos que escolhiam se dedicar às atividades públicas a oportunidade de tomar parte no poder. Mesmo quem não era especialista em teoria política, em questões econômicas e administrativas, e mesmo quem não pertencia a partido algum. Além disso, este sistema de poder era horizontal e realizava

\footnotetext{
${ }^{69}$ Ver em Sobre a Revolução, p. 314 e em Crises da República, p. 200 e 201.
} 
o verdadeiro princípio federativo de associação e aliança entre unidades. A autora afirma isso, principalmente, com base na experiência das Revoluções Húngara e Russa:

"O aspecto mais marcante desses desenvolvimentos espontâneos é que bastaram poucas semanas, no caso da Rússia, ou poucos dias, no caso da Hungria, para que esses órgãos independentes e extremamente díspares dessem início a um processo de coordenação e integração por meio da formação de conselhos superiores, de caráter regional ou provincial, dos quais finalmente eram escolhidos os delegados para uma assembleia representando o país inteiro" (Sobre a Revolução, p. 334).

Nesse sentido, para Arendt, o sistema de conselhos é capaz de estabelecer um corpo político em vasto território e garantir a igualdade política, a participação efetiva de cada um nos assuntos públicos.

Contudo, a autora assevera que esta forma de organização política não significa o paraíso na terra. Se fosse, ela teria se constituído de forma duradoura e teria desenvolvido uma nova forma de Estado. Em sua análise, principalmente duas questões contribuíram para que o sistema de conselhos não fosse institucionalizado: a indistinção entre o social e o político e o surgimento do sistema partidário.

Ao tratar das sociedades populares e das seções da comuna parisiense na Revolução Francesa, a autora aponta que o povo esperava que uma Constituição efetivasse a felicidade pública e privada. Os cidadãos, neste contexto, pressionavam por meio de cartas e petições os legisladores para que a miséria fosse extinta e, ao mesmo tempo, desenvolviam o espírito público, debatiam sobre os decretos promulgados e os princípios republicanos. ${ }^{70}$

Arendt ainda aponta que o mesmo ocorreu na comuna de Paris de 1871: o povo tratou conjuntamente dos problemas sociais e dos problemas políticos. Ela retoma as palavras de Odysse Barot para indicar que este levante popular retomou as questões sociais postas na França em 1793, mas com relação às questões políticas buscou dar continuidade às noções de liberdade republicana e à concepção federativa de poder defendidas em $1789 .^{71}$

Os conselhos nas Revoluções Russa e Húngara também buscaram reorganizar tanto a vida política quanto a econômica. Para a autora, os partidos revolucionários incentivaram

\footnotetext{
${ }^{70}$ Ver em Sobre a Revolução, p. 305.

${ }^{71}$ Conferir em Sobre a Revolução, p. 333.
} 
a formação de conselhos operários e camponeses voltados para a discussão de assuntos econômicos e de gestão de produção com a finalidade de neutralizar as aspirações políticas e fazê-los dedicar mais tempo ao trabalho do que à ação. ${ }^{72}$

Entretanto, segundo Arendt, o sistema de conselhos falhou em reconstruir o sistema econômico. Isto levou ao descrédito esta nova forma de organização. Este argumento da autora não nos parece muito consistente na medida em que ela não avaliou detidamente o funcionamento dos conselhos operários e camponeses. Por isso, sua contestação acerca da capacidade de gestão econômica dos conselhos carece de um estudo mais desenvolvido sobre a experiência de gestão coletiva da economia. ${ }^{73}$

De qualquer forma, concordamos com Arendt em que a administração é uma atividade distinta da ação política e em que é preciso organizar instituições diferentes para abrigar cada uma, caso se queira que as questões políticas e sociais sejam tratadas adequadamente.

Na perspectiva da autora, "O equívoco fatal dos conselhos sempre foi o problema que eles mesmos não distinguiam claramente entre a participação nos assuntos públicos e a administração ou gerenciamento das coisas no interesse público" (Sobre a Revolução, p. 342). Aqueles que agiram nos conselhos não entenderam que, na sociedade moderna, o governo deve executar funções administrativas. Nesta passagem, Arendt admite que, a partir do momento em que a questão social e a economia política invadiram a esfera pública, o Estado deveria exercer uma função na administração das coisas. No entanto, ela não esclarece detalhadamente como a administração poderia ser conciliada com o sistema de conselhos. A autora apenas ressalta que o que está em jogo no sistema de conselhos são critérios políticos, tais como coragem, integridade e discernimento. A capacidade técnica e administrativa de uma pessoa não é considerada nestes órgãos. Por este motivo, a eficiência de gestão econômica dos cidadãos em conjunto é questionada. ${ }^{74}$

De acordo com a autora, além da indistinção entre ação política e administração, outro fator que prejudicou a institucionalização do sistema de conselhos foi o conflito entre

\footnotetext{
${ }^{72}$ Sobre o sistema de conselhos e o engajamento na reorganização política e econômica, ver em Sobre a Revolução, p. 339. Com relação à manobra dos partidos para neutralizar o poder político dos conselhos operários, conferir em Sobre a Revolução, p. 342.

${ }^{73}$ Sobre os problemas da crítica de Arendt aos conselhos de trabalhadores ver também Kalyvas, Democracy and the Politics of the Extraordinary, p. 281.

${ }^{74}$ Ver em Sobre a Revolução, p. 343.
} 
estes órgãos populares e os partidos. Como mencionado acima, na América do Norte, a Carta Constitucional favoreceu as instituições representativas e partidárias em detrimento da ação do povo nos distritos e assembleias municipais; na França, por sua vez, o partido Jacobino perseguiu as sociedades e clubes populares; na Rússia, o partido Bolchevique investiu contra os sovietes; na Hungria, o exército russo massacrou os conselhos revolucionários a mando do partido Bolchevique.

Conforme Arendt, o sistema de partidos surgiu nas revoluções com a atuação de facções dentro do Parlamento. Desde sua origem, o partido se relaciona com o povo a partir de fora e de cima. Apesar de oferecer a possibilidade de formar um grupo dirigente saído do povo - isto é, os governantes no sistema de partidos não precisam possuir títulos de nobreza ou pertencer necessariamente a algum estamento ou a determinada classe - e procurar o consentimento popular por meio do voto, um partido não possibilita ao povo enquanto tal tomar parte nos assuntos públicos. No sistema partidário, a participação política do povo se restringe a votar em delegados indicados pelos partidos e a aclamar um programa de governo dentre os programas apresentados pelos partidos que disputam uma eleição. Nesse sistema, não há debate entre o partido e os eleitores, a opinião destes não é ouvida de forma a influenciar ou modificar o programa partidário. As eleições não permitem um debate público, antes oferecem uma forma de medir a preferência da maioria entre opções limitadas. Segundo a autora, a relação entre representantes e representados está mais para a relação entre vendedor e comprador do que para um vínculo público. ${ }^{75}$

Levando isso em conta, a autora afirma que os partidos não são órgãos populares, ao contrário, controlam e restringem o poder popular. Quando o sistema de partidos é o único estabelecido, em termos institucionais, os lugares onde a igualdade e a liberdade de falar, ouvir e decidir se concretizam são os Parlamentos e os Congressos. Os eleitores são excluídos destes espaços. ${ }^{76}$

Arendt indica que nos conselhos também se elegiam grupos para governar. A diferença, porém, consiste em que os eleitos pelo sistema de conselhos não eram indicados de cima, mas escolhidos pelos seus pares. Nesse sentido, a autora enfatiza que a escolha entre candidatos no sistema partidário pressupõe uma assimetria entre quem vota e quem

\footnotetext{
${ }^{75}$ Ver em Sobre a Revolução, p. 346.

${ }^{76}$ Conferir em Sobre a Revolução, p. 345.
} 
concorre à eleição. Nos conselhos, de forma diversa, vigora o princípio de auto-seleção: quem vota e quem se candidata estão igualmente comprometidos com um assunto ou interesse.

"Sem dúvida, essa forma de governo, se se desenvolvesse por completo, voltaria a ter a forma de uma pirâmide, que, claro, é a forma de governo essencialmente autoritário. Mas [...] neste caso a autoridade não se teria gerado nem em cima nem em baixo, e sim a cada camada da pirâmide [...]" (Sobre a Revolução, p. 347). ${ }^{77}$

Segundo Arendt, o que mais afasta conselhos dos partidos é o programa partidário: enquanto os conselhos promovem debates, a troca de opiniões e possibilitam a deliberação em conjunto, o programa partidário requer a execução prática de um plano previamente estabelecido, que não é necessariamente definido em um debate público. Ela ressalta que até mesmo um programa revolucionário está pautado na divisão entre os que definem o plano e os que o executam. Nesse sentido, os partidos, depois de definirem seus programas, abandonam a troca de opinião e a ação e procuram colocar seu plano em prática. Para a autora, "Sempre que o conhecer e o agir se separam, perde-se o espaço de liberdade" (Sobre a Revolução, p. 331).

3.4 Conflito entre o sistema de partidos e o sistema de conselhos e a história do conceito de governo.

Durante o século $\mathrm{XX}$, o embate entre o sistema de conselhos e o sistema partidário ocupou o primeiro plano das revoluções. Tal embate se desdobra, teoricamente falando, em dois conflitos. O primeiro envolve a representação e a participação, isto é, a disputa entre uma instituição que reclama o monopólio do governo e uma constituição e articulação de diversos centros de poder. Em outras palavras, de um lado, os defensores da representação afirmam a divisão entre quem decide e quem obedece e, de outro, os defensores do espírito público e do princípio federativo. O segundo conflito diz respeito à finalidade da atividade política, a batalha entre a concepção de que o governo deve primordialmente promover a

${ }^{77}$ É importante esclarecer que, embora o governo autoritário tenha a forma de pirâmide, ele carece de autoridade política, que se assenta na confiança e no reconhecimento de que alguém está apto para aconselhar a ação. O governo autoritário está baseado na coerção, isto é, faz com que as ordens que emanam de cima sejam cumpridas na parte de baixo da pirâmide. 
liberdade de debater, deliberar e agir, e a concepção de que governar significa, principalmente, promover o bem-estar privado ou social, isto é, a ideia de que o governo deve ajudar a desenvolver a economia ou sanar o problema da miséria. ${ }^{78}$

Historicamente, a disputa nas revoluções entre o sistema de conselho e o sistema de partido consistiu na disputa entre participação e representação. Como vimos, Arendt aponta que o sistema de partidos conseguiu se estabelecer em detrimento do sistema de conselhos. No entanto, a partir da análise da autora, é possível ver que, no século XX, os partidos se desgastaram, principalmente, por não serem capazes de responder às demandas feitas ao governo. Por um lado, os partidos, em algumas ocasiões, mostraram-se incapazes de representar adequadamente o povo e com isso foi aberto espaço para o surgimento de movimentos de massa. ${ }^{79}$ De acordo com a autora, na Revolução Francesa, viu-se que, sem um espaço para expressão e formação de opinião, interesses e juízos compartilhados, sem vínculo público, os sofrimentos pessoais podem se transformar em sentimentos de massa. ${ }^{80}$ Com o nazismo, por sua vez, foi possível entender que a raiva generalizada contra o governo e contra as instituições e a falta de laços públicos fazem com que muitos sejam alvo fácil da ideologia totalitária. Nas palavras da autora, “[...] quanto mais flagrantes são as falhas do sistema partidário, mais fácil será que um movimento não só tenha apelo para o povo e venha a organizá-lo como também transforme o povo em massa" (Sobre a Revolução, p. 338).

Assim, para Arendt, é importante tratar de alternativas ao sistema partidário. Contudo, segundo ela, o pensamento político do século XX e a tradição revolucionária não entenderam que o sistema de conselhos tem a potência de se tornar uma nova forma de corpo político, eficaz em evitar a formação de massas e a cooptação destas por movimentos totalitários. Ao passo que as massas são constituídas por pessoas isoladas, com pouquíssimos laços privados e públicos, a abertura de espaços de troca e refinamento de opiniões permite a formação de vínculos públicos. Os conselhos oferecem espaço para participação ampliada e, nessa medida, são capazes de romper com a sociedade de massas moderna. ${ }^{81}$

\footnotetext{
${ }^{78}$ Conferir em Sobre a Revolução, p. 308-309 e 341.

${ }^{79}$ Ver em Sobre a Revolução, p. 338.

${ }^{80}$ Conferir em Sobre a Revolução, p. 289.

${ }^{81}$ Ver em Sobre a Revolução, p.348.
} 
Por outro lado, a noção de que a finalidade do governo seria promover o bem estar social também contribuiu para o desgaste do sistema partidário. Historicamente falando, o conflito entre ação e administração, desde as primeiras revoluções enredou grande parte dos atores políticos, tanto os que atuavam nos partidos como os que agiam nos conselhos. Como foi apontado por Arendt, tanto as facções nos Parlamentos como os conselhos não distinguiram claramente entre questões políticas e sociais. Na Revolução Francesa, por exemplo, alguns membros da Assembleia Nacional que se dedicaram ao debate constitucional foram pressionados pelos sans-culottes a abandonar o debate sobre a constituição de uma república para se concentrarem na resolução do problema da miséria. De forma semelhante, o debate político foi desviado quando a questão da necessidade e da pobreza invadiu os clubes, comunas e sociedades populares.

Vimos que, conforme Arendt, os conselhos são órgãos de ação e participação e que a preocupação excessiva com a organização da economia foi um dos fatores que obliterou a atividade política dentro destes órgãos. Para ela, a administração também pode destruir a pouca atividade política requerida no sistema partidário. Quando a noção de que o governo tem como principal função a administração das coisas é promovida, a utilidade da representação partidária é colocada em questão. Qualquer partido que tenha como objetivo primordial sanar a questão social ou desenvolver a economia, por mais revolucionário que seja, irá fatalmente favorecer o governo de especialistas.

"Os defensores desse sistema, que atualmente é o sistema do estado de bemestar social, precisam negar, se são liberais e possuem convicções democráticas, a própria existência da felicidade e da liberdade públicas; precisam insistir que a política é um fardo e que seu fim não é político em si" (Sobre a Revolução, p. 337).

A partir do momento em que a administração das coisas se torna a principal preocupação pública, os partidos podem ser facilmente substituídos pela burocracia. Quando o governo se resume a atender as necessidades da vida, não há o que ser debatido, uma vez que todos os que pertencem à espécie humana possuem as mesmas necessidades biológicas. Nesse contexto, a atuação dos partidos pode ser abandonada: as instâncias técnicas do Estado são valorizada em detrimento do Parlamento e do Congresso.

A autora aponta, portanto, para uma progressiva perda de espaço de ação no momento em que a administração se torna a função do governo por excelência: primeiro a 
participação é suplantada pela representação, para depois a burocracia substituir os representantes.

"Portanto, desde o início, o partido como instituição pressupunha ou que a participação nos assuntos públicos era garantida por outros órgãos públicos, ou que tal participação não era necessária e as camadas da população recémadmitidas deveriam se contentar com a representação ou, por fim, que todas as questões políticas no Estado de bem-estar social são, em última análise, problemas administrativos, a ser tratados e decididos por especialistas, caso em que nem mesmo os representantes do povo chegam a dispor de uma autêntica área de ação [...]" (Sobre a Revolução, p. 340).

Levando isso em consideração, é possível identificar que os conflitos entre representação e participação e entre ação e administração revelam uma história do conceito de representação e uma história do conceito de governo.

Ficou claro que, a partir das revoluções, emergiu a noção de que governar envolve tanto a fabricação quanto a administração. Nas palavras da autora: "o governo, no sentido antigo, deu lugar, em muitos aspectos, à administração [...]" (Entre o Passado e o Futuro, p. 47). A preocupação com o social engendrou duas concepções, a saber, a de fazer uma nova sociedade e a de gerenciar economicamente o trabalho e as coisas produzidas. Em outras palavras, teoricamente, governar se tornou, em um primeiro momento, executar um plano para mudar de alto a baixo a sociedade e, em um segundo, manter e reproduzir tal sociedade. A novidade e a durabilidade, que no início da revolução se referiam à política, foram traduzidas para as questões sociais na medida em que surgiu a noção de fazer e gerir uma nova sociedade.

Embora em Sobre a Revolução a autora indique as mudanças de significado sofridas no conceito de governo depois dos eventos revolucionários do século XVIII, a origem e a história deste conceito são mais bem expostas em A Condição Humana. A concepção de governo, em termos teóricos, surgiu com Platão. De acordo com Arendt, os homens sempre foram tentados a procurar um substituto para a ação, exasperados com suas características que trazem certos riscos para os assuntos públicos. Por envolver uma pluralidade de agentes - cada um dotado de espontaneidade e singularidade -, a ação é imprevisível e irreversível: seus rumos não podem ser determinados de maneira segura. A ação, nesse sentido, pode ser malfadada e seus efeitos ruins podem perdurar por muito tempo. Além disso, não é possível responsabilizar moralmente todas as pessoas envolvidas numa ação malfadada. 
Na perspectiva da autora, uma vez que a fragilidade da ação está ligada à pluralidade, as tentativas de superar os riscos da atividade política geralmente acabam por eliminar a pluralidade do domínio público. ${ }^{82}$ Em suas palavras:

"A fuga da fragilidade dos assuntos humanos para a solidez da quietude e da ordem tem sido realmente tão recomendada que a maior parte da filosofia política, desde Platão, poderia ser facilmente interpretada como uma série de tentativas de encontrar fundamentos teóricos e meios práticos de uma completa fuga da política" (A Condição Humana, p. 277).

Tanto os filósofos quanto outros homens que se engajaram nos assuntos públicos se depararam com as dificuldades próprias da ação. Com isso, muitos deles buscaram outra atividade para organizar o mundo e as relações entre os homens. Se os filósofos defendiam o conceito de governo como dominação, os homens envolvidos na condução de assuntos públicos muitas vezes procuraram práticas que reduziam a pluralidade do espaço público e das decisões. Por exemplo, muitos defendiam formas de governo como a monarquia, a tirania, a aristocracia ou oligarquia, que impediam o acesso ampliado ao espaço público.

De acordo com Arendt, a filosofia política inaugurada por Platão busca escapar da imprevisibilidade e da irreversibilidade própria da ação ao defender a figura do reifilósofo, o qual é senhor do início do ato e de seu desenrolar. Platão separa completamente começar [archein] e realizar [prattein], que na concepção política grega estavam intimamente conectados. Com esta separação, o iniciador permanece senhor daquilo que começou ao impedir que os outros envolvidos no empreendimento tenham alguma iniciativa e possam mudar ou adicionar algo ao empreendimento. Segundo Arendt, em $A s$ Leis, Platão afirma que o início [arché] determina o governo. Neste caso, o autor não trata de um ato inicial que é levado adiante por meio da ação livre de outros agentes, mas trata da execução de um plano definido por um governante. ${ }^{83}$

"Na República, o rei-filósofo aplica as ideias como o artesão aplica suas regras e padrões; 'faz' sua cidade como o escultor faz uma estátua [...]” (A Condição Humana, p. 283). Para Arendt, a concepção principal da filosofia platônica, o termo ideia, vem da fabricação, pois a imagem ou a forma [eidos] do produto que será fabricado determina todo o processo de produção, os meios, instrumentos e modo de execução. Nesse sentido, a

\footnotetext{
${ }^{82}$ Ver em $A$ Condição Humana, p. 275.

${ }^{83}$ Conferir em A Condição Humana, p. 278.
} 
contemplação deve imperar sobre a ação, prescrever regras que devem ser seguidas na vida política. $^{84}$

Estas concepções de Platão contaminaram toda a tradição do pensamento político. E no decorrer do tempo, de alguma forma, a noção de iniciar desapareceu do conceito de governo e, assim, governar se tornou sinônimo de dominar. Conforme Arendt, Aristóteles, por exemplo, procura estabelecer uma legitimidade para explicar a divisão entre governantes e governados e define o governo como dominação. ${ }^{85}$

Contudo, apesar desta concepção platônica de governo como fabricação ter perpassado toda a tradição filosófica, ela não chegou a desempenhar um papel perceptível na história até a Modernidade. Somente a partir daí a identificação entre governar e fabricar teve implicações históricas relevantes. Com a ascensão do homo faber, isto é, da convicção de que a atividade mais importante realizada pelo homem é a fabricação e com o desenvolvimento dos meios de coerção e violência, foi possível governar nos moldes do fazer. Nas palavras da autora, as revoluções revelam "a mesma combinação do antigo entusiasmo romano pela fundação de um novo corpo político com a glorificação da violência como único meio de 'produzir' esse corpo" (A Condição Humana, p. 285). No momento em que a mentalidade do homo faber foi valorizada, os homens modernos puderam recorrer à filosofia política para buscar formas de suplantar a ação. Como já foi mencionado, segundo Arendt, Robespierre foi a figura que adotou este modelo de fabricação e usou da violência com o objetivo de fazer a república francesa.

Para ela, a substituição da ação pela fabricação implica em instrumentalizar a política. A produção de uma coisa deve ser sempre útil. O produto serve para algum fim, nesta perspectiva, o governo também deve ter uma finalidade.

"A substituição da ação pela fabricação e a concomitante degradação da política em um meio para atingir um fim supostamente 'superior' - na Antiguidade, a proteção dos bons contra o domínio dos maus, em geral, e a segurança dos filósofos em particular; na Idade Média, a salvação das almas; e, na era moderna, a produtividade e o progresso da sociedade - são tão antigas quanto a tradição da fillosofia política" (A Condição Humana, p. 286).

$\mathrm{Na}$ perspectiva arendtiana, os objetivos que o governo deve atingir também possuem uma história: para os filósofos antigos, o governo deveria garantir o bem comum

\footnotetext{
${ }^{84}$ Ver em Entre o Passado e o Futuro, p. 154 e 155.

${ }^{85}$ Conferir em "Karl Marx and the Tradition of Western Political Thought", p. 275.
} 
e a segurança de quem se dedicava à contemplação; para a filosofia cristã, o objetivo passou a ser uma certa ordem na esfera secular para que fosse possível a dedicação à vida interior e à salvação; na Modernidade, por sua vez, a valorização do homo faber fez com que o governo se preocupasse, primeiramente, com a produtividade e, depois, com o processo vital. ${ }^{86}$

A autora, depois de indicar a ascensão do homo faber e a glorificação da atividade de fabricar na Modernidade, mostra que a mentalidade do fabricante foi suplantada pela mentalidade do animal laborans, isto é, pela concepção de que o trabalho e o consumo consistem na principal atividade humana. ${ }^{87}$ De maneira resumida, em $A$ Condição Humana, argumenta-se que, na Antiguidade, o mundo - criado e preservado por meio de atos, discursos e os artefatos culturais - consistia a principal preocupação dos homens. ${ }^{88}$ Ele deveria ser preservado para que as coisas e feitos humanos perdurassem no tempo, e assim a mortalidade dos homens fosse remediada. Com o surgimento do cristianismo, a alma de cada homem foi dotada de imortalidade. Assim, a vida individual foi considerada sagrada e a vida interior foi valorizada em detrimento do mundo. ${ }^{89} \mathrm{Com}$ a secularização, a vida individual volta a ser considerada mortal, como fora na Antiguidade. No entanto, a imortalidade passa a ser entendida como atributo da espécie humana. A vida biológica se torna, então, um bem supremo. ${ }^{90}$

Nesse contexto, o trabalho passou a ser a atividade humana mais importante e as coisas que não eram necessárias para manter o processo vital se tornaram secundárias ou supérfluas. Com isso, as demais atividades humanas sofreram mudanças. Os produtos da fabricação perderam sua característica de durabilidade: ou se tornaram objeto de consumo ou meros instrumentos para fazer outros bens de consumo. Eles entraram em um incessante

\footnotetext{
${ }^{86}$ Vale sublinhar que, embora o conceito de governo como dominação, desde sua origem, tenha trazido sérios empecilhos para a atividade política, não conseguiu eliminá-la por completo.

${ }^{87}$ Sobre a promoção da fabricação e a emergência da mentalidade do homo faber, ver em A Condição Humana, p. 368-381.

${ }^{88}$ Para Arendt, "Se alguém soubesse que o mundo acabaria quando ele morresse, ou logo depois, esse mundo perderia toda a sua realidade, como a perdeu entre os primeiros cristãos, na medida em que estavam convencidos de que as suas expectativas escatológicas seriam imediatamente realizadas" (A Condição Humana, p. 149).

${ }^{89}$ Arendt ressalta que, embora a vida individual tenha sido valorizada com o cristianismo, a filosofia cristã não desenvolve uma doutrina positiva do trabalho. A tradição cristã admite que esta atividade é responsável por manter um organismo vivo, mas enfatiza a contemplação uma vez que a alma é mais importante que o corpo.

${ }^{90}$ Conferir em A Condição Humana, p. 399-401.
} 
processo de produção e desgaste. Ainda, isto provocou mudança nos assuntos comuns, que foram invadidos por questões sociais na medida em que o governo passou a ser relacionado com a sobrevivência e com a produtividade do trabalho. ${ }^{91}$

Segundo Arendt, na Modernidade, o governo não é entendido como responsável somente por organizar o mundo e a convivência entre os membros de uma comunidade, mas passa também a organizar o trabalho. Para Wellmer, Arendt critica a noção de que as instituições públicas possuem uma outra finalidade além da política. Elas têm o papel de preservar e resguardar um espaço para a ação e o debate dos assuntos públicos. Com isso, de acordo com este comentador, a autora combate tanto a teoria marxista quanto a liberal na medida em que ambas entendem que a política consiste em um meio para um fim não político. A primeira entende que o Estado deve proporcionar a igualdade social e o fim da necessidade, a segunda, por sua vez, defende que o governo deve proporcionar o bem-estar individual. ${ }^{92}$ Vimos que a autora afirma que a tradição marxista acaba por negligenciar a nova forma política que surgiu com os conselhos por favorecer um Estado centralizado e forte, capaz de sanar com rapidez a questão social e promover a igualdade na sociedade. Com relação ao liberalismo, vimos que ela argumenta que o modelo de governo representativo restringe a participação ampliada na política e, com isso, os vínculos e os interesses públicos podem ser perdidos. Nesse sentido, a noção de que o corpo político é somente um meio para um atingir um objetivo privado ou social leva, fatalmente, à redução do espaço de ação e de liberdade.

A partir dessa reflexão de Arendt pode-se entender que o objetivo estabelecido para o corpo político influi muito na definição da forma de governo. O governo baseado nos moldes da fabricação assume, preferencialmente, a forma da ditadura moderna: apenas um homem define o que deve ser feito e os outros executam ordens. Mas, com a vitória do animal laborans, a forma de governo mais adequada passa a ser a burocracia, que é mais eficiente para administrar as coisas necessárias ao processo vital. Nas palavras da autora:

"É verdade que o governo de um só homem, o governo monárquico, que os antigos diziam ser a forma organizacional da família, é transformado na sociedade (como hoje a conhecemos, quando o topo da ordem social já não é constituído pela casa real de um governante absoluto) em uma espécie de governo de ninguém. Mas esse ninguém, o suposto interesse da sociedade como

\footnotetext{
${ }^{91}$ Ver em A Condição Humana, p. 393.

${ }^{92}$ Conferir em "Arendt on revolution", p. 219.
} 
um todo em questões econômicas, assim como a suposta opinião única da sociedade educada nos salões, não deixa de governar por ter perdido sua personalidade. Como verificamos pela forma mais social de governo, isto é, pela burocracia (o último estágio do governo no Estado-nação, tal como o governo de um só homem constituía o primeiro estágio do despotismo benevolente e do absolutismo) o governo de ninguém não é necessariamente um não governo; pode, de fato, em certas circunstâncias, vir a ser uma das formas mais cruéis e tirânicas versões." (A Condição Humana, p. 49).

O governo de ninguém consiste no governo que não se baseia em opinião pessoal ou interesse compartilhado, mas na convicção de que a opinião e o interesse são irrelevantes. Uma vez que os homens pertencem à mesma espécie e possuem o mesmo metabolismo, as mesmas necessidades biológicas, o governo deve simplesmente administrar o trabalho e a sociedade..$^{93}$

A burocracia faz com que o Estado funcione de acordo com certas regras determinadas por um saber técnico e por especialistas. Assim, a autoridade da burocracia não é política uma vez que não pressupõe o reconhecimento dos especialistas como pessoas aptas a aconselhar os agentes sobre a vida pública. A autoridade da burocracia se parece com a autoridade dos cientistas, que é definida pelos próprios cientistas por meio de critérios objetivos que envolvem a comprovação de hipóteses e excluem o debate e a persuasão em um espaço público. ${ }^{94}$ As regras burocráticas, nesse sentido, devem compelir a todos do mesmo modo que as verdades científicas.

A autora aponta que a emergência da burocracia está relacionada com a transformação das questões econômicas em questões públicas. Dito de outra forma, a burocracia se torna importante quando o objetivo do governo passa a ser o aumento da riqueza ou a diminuição da pobreza. Nesse contexto, a economia surge como a ciência que poderia estabelecer as regras que o Estado deveria adotar.

De acordo com Arendt, a economia, originalmente, pertencia ao domínio do lar [oikos], dizia respeito à administração da atividade do trabalho para garantir a sobrevivência e o bem-estar dos membros de uma família. Na perspectiva econômica, os homens são vistos como seres uniformes e homogêneos que têm as mesmas necessidades biológicas e experimentam mais ou menos as mesmas penas ao trabalhar e o mesmo prazer

\footnotetext{
${ }^{93}$ Conferir em A Condição Humana, p. 56. Sobre burocracia, ver também em A Promessa da Política, p. 127.

${ }^{94}$ Ver em Sobre a Revolução, p. 348.
} 
ao consumir. No momento em que a economia adentrou nos assuntos públicos, não alterou de forma significativa seus pressupostos. ${ }^{95}$ Ela não considerou os membros da comunidade política em sua pluralidade, com opiniões e pontos de vistas diferentes, mas os concebeu como uma grande família que deveria ter a força de trabalho organizada e sua única preocupação atendida: a sobrevivência e o bem-estar.

$\mathrm{Na}$ medida em que os homens são vistos como seres homogêneos que não possuem opiniões distintas, o debate público é negligenciado e a pluralidade de perspectivas é embotada. Além disso, como a economia entende que os homens têm uma única preocupação, pressupõe que eles se comportam de uma determinada forma e, dessa maneira, a ação espontânea é obliterada.

"É o mesmo conformismo, a suposição de que os homens se comportam ao invés de agir em relação aos demais, que está na base da moderna ciência da economia, cujo nascimento coincidiu com o surgimento da sociedade e que, juntamente com seu principal instrumento técnico, a estatística, se tornou a ciência social por excelência" (Arendt, A Condição Humana, p. 50).

Para Arendt, as ciências que utilizam o método estatístico buscam mais do que estabelecer uma tendência, ou prever e antever os comportamentos, elas visam também a impor este comportamento. Ela identifica um vínculo entre administração burocrática e comportamento: o governo burocrático é mais eficaz na gestão da sociedade sem ser incomodado pela ação política, pela espontaneidade e pluralidade humana. Em outras palavras, a burocracia melhor estabelece seu domínio onde os homens possuem uma opinião unânime e se comportam ao invés de agir. Em suas palavras:

“[...] sua inicial substituição da ação pelo comportamento e sua posterior substituição do governo pessoal pela burocracia, que é o governo de ninguém, pode convir também lembrar que sua ciência inicial, a economia, que altera padrões de comportamento somente nesse campo bastante limitado da atividade humana, foi finalmente sucedida pela pretensão oniabrangente das 'ciências sociais' que, como 'ciências do comportamento', visam a reduzir o homem como um todo, em todas as suas atividades, ao nível de um animal comportado e condicionado" (A Condição Humana, p. 55).

O moderno conceito de governo está baseado no conhecimento da economia e das ciências do comportamento, que prescrevem como os homens devem se comportar para

\footnotetext{
${ }^{95}$ Segundo Arendt, a economia política clássica, desde seu início, entendia que todas as atividades humanas tinham como finalidade a produção de riqueza e de abundância para garantir a satisfação do maior número de indivíduos. Conferir em A Condição Humana, p. 165.
} 
maximizar seus interesses privados e contribuir para a produtividade como um todo. ${ }^{96} \mathrm{De}$ forma distinta, o conceito de governo tradicional estava baseado na verdade e, com isso, não estava voltado para o trabalho, mas para a contemplação, para a busca da sabedoria.

Levando isso em conta, vemos que, em A Condição Humana, Arendt aponta que o conceito de governo formulado por Platão influenciou a tradição e legitimou, teoricamente falando, a substituição da ação pela fabricação, a divisão entre governantes e governados e divulgou a concepção de que o governo tem uma finalidade externa à política. Com a ascensão do homo faber, a noção de que o governo consiste em um meio para atingir uma finalidade foi reforçada. O surgimento do animal laborans, por sua vez, promoveu a vida biológica, a administração e a burocracia como forma de governo.

Em Sobre a Revolução, a autora retoma de certo modo estes temas e discute suas implicações nos eventos revolucionários. A influência da tradição e a adoção da fabricação em detrimento da ação são analisadas por meio da atuação de Robespierre. Este revolucionário entendeu que fundar consistiria em fazer uma república de alto a baixo. A emergência da preocupação com as necessidades vitais é tratada por meio da questão social. Como foi exposto no capítulo anterior, a noção de vontade geral da nação promoveu a ideia de que o povo é homogêneo e possui uma vontade unânime.

O conflito entre ação e administração que surgiu no interior da disputa entre o sistema de conselhos e o sistema partidário, por um lado, mostrou que a invasão de questões privadas na vida pública é incontornável: todo governo deve envolver em alguma medida a administração. A própria concepção de libertação, que foi ressignificada com as revoluções, indica isso: é preciso garantir que todos se libertem da dominação e do jugo da necessidade para que tenham acesso ao espaço público. Por outro lado, o conflito entre conselhos e partidos mostrou o perigo da ação ser suplantada pela burocracia.

Como já indicamos antes, Arendt não desenvolve uma reflexão sobre o modo pelo qual seria possível conciliar administração e ação de forma que a libertação da necessidade seja alcançada ao mesmo tempo em que a atividade política seja resguardada. Contudo, ao refletir sobre a experiência nos conselhos revolucionários, a autora encontra uma forma nova de corpo político e de governo. Sua concepção de governo é expressa claramente em

\footnotetext{
${ }^{96}$ As ciências do comportamento, em geral, usam a estatística, que é capaz de calcular a média, o padrão e de descartar os desvios.
} 
Sobre a Violência. Neste ensaio, a autora indica um sentido de governo que está pautado nas experiências em que a ação foi considerada a principal atividade humana, como no início das revoluções. Esta definição de governo está ligada às instituições que abrigam o debate e a deliberação, à liberdade, à pluralidade humana e ao ato de iniciar [archen] e de realizar [prattein] no sentido original grego. Nas palavras da autora:

"E posto que o governo [government] é essencialmente poder organizado e institucionalizado, a questão ordinária 'qual é o fim [finalidade] do governo?' também não faz muito sentido. A resposta será redundante - possibilitar que os homens vivam em comum - ou perigosamente utópica - promover a felicidade ou concretizar a sociedade sem classes ou qualquer outro ideal não político, o qual, se tentado com perseverança, só pode acabar em alguma forma de tirania" (Sobre a Violência , p. 69.)

A autora defende a concepção de governo como institucionalização da participação e dos espaços de aparência de diversas opiniões. A finalidade do governo, em sua perspectiva, consiste em garantir que a convivência entre os membros de uma comunidade não seja pautada apenas pelas necessidades, mas, principalmente, por laços públicos e pela liberdade. Vale lembrar que, de acordo com ela, “[...] a liberdade política, em termos gerais, significa o direito de ser 'participante do governo' - afora isso, não é nada" (Sobre a Revolução, p. 278).

Arendt, a partir das experiências revolucionárias, indica uma nova forma de governo que não foi resguardada pela tradição revolucionária: o sistema de conselhos. Ao narrar a história das revoluções, ela, além de discutir esta promissora forma de organização política popular, também mostra como a noção de fabricação e administração mudaram a concepção de governo e contribuíram para a redução do espaço de ação.

É importante sublinhar que, de acordo com Arendt, política não se resume ao governo: esta atividade não se dá somente dentro de instituições, mas também na rua e na praça pública. Certos tipos de ação não podem se desenrolar somente dentro de instâncias oficiais. Isso fica claro quando a autora trata das associações voluntárias e da desobediência civil. Como foi tratado no capítulo anterior, as associações voluntárias se formam quando os cidadãos recorrem uns aos outros em busca de resolver um problema comum e, logo que o problema é resolvido, a associação se desfaz. Trata-se de organizações ad hoc, espontâneas e temporárias. A desobediência civil, geralmente, é iniciada por grupos que se associam voluntariamente e consiste em um tipo de ação que se 
dá fora das instituições, mas que visa a persuadir o governo. Conforme Arendt, a contestação civil combate uma lei ou ato do governo e tem como objetivo impedir mudanças que afetam negativamente a vida política ou modificar uma lei considerada injusta. Em sua perspectiva, como a atividade política se dá em diversos espaços e de modos distintos, é importante que o governo, além de possibilitar a participação ampliada, seja capaz de ouvir as vozes de atores que atuam fora das instituições.

Kalyvas corrobora isto ao afirmar que, no pensamento arendtiano, a política institucional, por mais bem estabelecida que seja, não pode impossibilitar formas mais espontâneas e irregulares de intervenção política. Para ele, a desobediência civil consiste em uma manifestação política fluida que faz uma mediação entre a política regular e a extraordinária. A contestação civil é uma ação extra-legal, fora das instituições, mas que visa uma mudança nas leis e nas instâncias governamentais. Nesse sentido, este tipo de ação é importante para a autora na medida em que reafirma a ligação entre a política

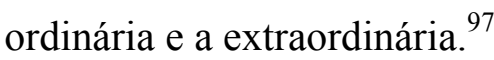

Levando isso em conta, discordamos da interpretação de Wellmer, que submete o pensamento de Arendt à teoria de Habermas. O comentador entende que o sistema de conselhos consiste em uma rede de instituições, organizações e associações que pode ser uma metáfora para representar tanto um sistema político federal, isto é, o Estado, quanto a sociedade civil. ${ }^{98}$ De forma distinta, interpretamos que o sistema de conselhos consiste em uma forma alternativa de organização do Estado que surgiu em vários levantes revolucionários. Tal organização, embora tenha surgido espontaneamente, deveria ter sido institucionalizada, isto é, ter sido resguardada por alguma Constituição revolucionária. Em outras palavras, o sistema de conselhos surgiu com ações extraordinárias, mas está ligado à política ordinária na medida em que busca tornar regular a liberdade pública e a ação.

Levando em consideração a perspectiva da autora sobre a relação entre ação institucional e ação espontânea, o modo de agir dentro dos conselhos não deve impedir ou formatar todos os tipos de ação, isto é, uma vez instituídos, eles não devem abafar manifestações políticas fluidas e externas. Entendemos que aproximar as categorias habermasianas de sociedade civil e sistema político das categorias arendtianas, como

\footnotetext{
${ }^{97}$ Conferir em Democracy and the Politics of the Extraordinary, p. 284, 288 e 291.

${ }^{98}$ Ver em "Arendt on revolution", p. 224.
} 
Wellmer faz, não produz ganhos interpretativos. Em nossa interpretação, parece ser mais indicado tratar da política regular - dentro de instituições - e da política extraordinária espontânea e temporária - nos próprios termos da autora.

Além disso, também discordamos de Waldron no que concerne a ação extraparlamentar. Para ele, a ação fora das instituições é perigosa na medida em que não possui limites e regras estabelecidas, ela compromete a estabilidade do corpo político e pode facilmente conduzir ao terror. ${ }^{99}$ Como foi mencionado antes, este autor indica que a maioria dos comentadores do pensamento arendtiano trata dos aspectos espontâneos e agonísticos da ação em detrimento de seus aspectos institucionais. ${ }^{100}$ Waldron, ao contrário, sublinha que a atividade política precisa de estrutura para abrigá-la, de regras que limitam e estabilizam a política. Só assim os lugares onde a ação se desenrola adquirem durabilidade. No entanto, ele acaba por obliterar a reflexão sobre as manifestações fluidas e espontâneas da política, e não discute a relação entre a ação institucional e a ação popular na praça pública, como as ações de contestação civil. Estas, diferentemente da ação de resistência, não buscam romper com a autoridade e a forma de governo vigentes, embora também se desenrolem fora de instituições. ${ }^{101}$

Neste contexto, alguns comentadores parecem ter criado uma falsa oposição entre a ação espontânea e os atos de governo. Neste ponto, Kalyvas mostra uma reflexão sobre a obra de Arendt mais equilibrada: identifica tanto as ações regulares quanto as extraordinárias e procura as ligações e mediações entre elas. Este autor contribui, principalmente, em dois aspectos, a saber, ao indicar como a ação extraordinária pode constituir um governo e ao apontar como a ação de associações voluntárias ou as manifestações de contestação civil podem influenciar o governo.

O conceito de governo defendido por Arendt, nesse sentido, apesar de envolver a institucionalização de espaços onde cada cidadão possa participar dos assuntos comuns, não impede modos temporários e não regulares de ação. Isto porque a finalidade do governo, para Arendt, consiste em promover os vínculos públicos entre os membros de

\footnotetext{
${ }^{99}$ Conferir em "Arendt's constitutional politics", p. 209-210.

${ }^{100}$ Ver em “Arendt's constitutional politics", p. 202.

${ }^{101}$ Vimos, no segundo capítulo desta tese, que o ato de contestação civil não é o mesmo que resistência ou que ação revolucionária. Embora uma revolução possa ter sua origem em uma contestação, esta não leva necessariamente à derrubada de um regime político.
} 
uma comunidade e em permitir a ação livre. Vale lembrar que, nesta perspectiva, o principal objetivo do governo não tem relação com a produtividade econômica ou com a necessidade.

Com relação a isso, Wellmer levanta uma objeção contra o pensamento arendtiano. Para ele, ao contrário do que afirma a autora, a pobreza e a desigualdade social consistem em problemas políticos e não podem ser resolvidas somente por meio da administração. ${ }^{102}$ Este autor entende que as distinções de Arendt entre social e político, administração e ação resultam em separações entre estas duas esferas e estas duas atividades que não permitem qualquer relação ou mediação entre elas. Embora esta interpretação seja possível uma vez que a autora apresenta suas distinções de forma exagerada, enfatizando as diferenças entre os conceitos, ${ }^{103}$ parece ser mais produtivo considerar também o caráter relacional das distinções. Vale lembrar que o procedimento de distinção formulado por Arendt envolve tanto a indicação da diferença entre conceitos que foram amalgamados pela filosofia como, por exemplo, poder e violência, o político e o social - quanto apontar as relações entre eles. ${ }^{104}$

Conforme foi tratado acima, apesar de Arendt distinguir administração de ação, ela admite que a administração das coisas em interesse público é uma das funções do Estado. A autora afirma que as qualidades administrativas e políticas são diferentes: uma requer conhecimento econômico, enquanto a outra requer apreço pela liberdade. Por isso, deve haver instituições distintas para tratar dos problemas relativos a cada esfera. Quando as mesmas instituições e as mesmas pessoas cuidam tanto de questões sociais como de assuntos políticos é grande o risco de uma atividade ser negligenciada em nome da outra. Arendt ainda alerta que em razão da ascensão da mentalidade do animal laborans é mais provável que a ação perca espaço para a administração, que visa à produtividade do trabalho e ao incentivo ao consumo.

Correia afirma que a criação do sistema de conselhos permitiu a Arendt pensar em novas possibilidades para a política em seu tempo, mas, concomitantemente, a emergência

\footnotetext{
${ }^{102}$ Conferir em "Arendt on revolution", p. 234.

103 Tratamos no primeiro capítulo desta tese sobre o caráter exagerado das distinções arendtianas. Mais sobre o assunto ver em Bernstein, Violence: thinking without banisters, p. 97.

${ }^{104}$ Com relação ao procedimento de distinção e seu caráter relacional, ver em Duarte, "Poder e violência no Pensamento de Hannah Arendt: uma reconsideração", p. 137.
} 
da questão social nas revoluções mostrou "o risco notável de subjugação da liberdade e da felicidade públicas aos ditames do processo vital" (Hannah Arendt e a Modernidade, p. 199). A partir dos eventos revolucionários, a autora identifica a possibilidade de uma nova forma de governo capaz de dar espaço para a liberdade e a ação, apesar da valorização da vida e do trabalho. Com o sistema de conselhos, a atividade política teria alguma proteção contra o constante assédio da necessidade e da administração.

Arendt, ao indicar que o conceito de governo tem uma genealogia e uma história, esclarece como as revoluções foram impactadas pelas as noções de que é melhor evitar a ação para eliminar a irreversibilidade e a imprevisibilidade nos assuntos públicos e de que o governo engendra uma divisão entre quem dá ordem e quem obedece. Ela também mostra como as mentalidades do homo faber e do animal laborans influenciaram o curso das revoluções. E, ainda, aponta que o modo pelo qual a redução do espaço público, o controle dos atos dos agentes e a defesa da burocracia nas revoluções estavam relacionados com as mudanças no sentido do conceito de governo. Por fim, por meio da história deste conceito, a autora identifica a definição de governo resguardada pela tradição revolucionária - que combina a fabricação e a administração das coisas - e recupera uma definição de governo que preserva a ação e a pluralidade, que surgiu com o sistema de conselhos.

\subsection{Mudança no significado de representação}

Arendt indica também uma história do conceito de representação. Para ela, antes da Revolução Norte-Americana, a questão da representação tinha sido discutida na Inglaterra, notadamente, por Sidney e Burke. Ambos entendiam que, depois de eleitos, os representantes não deveriam ser dependentes daqueles que representavam. Contudo, na Convenção Constitucional da Filadélfia, esta concepção consagrada na tradição inglesa foi descartada e a representação passou a ser considerada como um substituto da ação direta do povo: "[...] os representantes eleitos deveriam agir de acordo com as instruções dadas por seus eleitores, e não tratar os assuntos de acordo com as opiniões pessoais que formavam durante o processo" (Sobre a Revolução, p. 298). Nessa perspectiva, os eleitores 
tinham o direito de instruir os representantes por meio de petições e cartas, e os representantes tinham o dever de acatar a instrução dada pelo povo.

Para Arendt, a questão da representação se tornou crucial na política desde as revoluções na medida em que passou a engendrar uma decisão com relação à dignidade da esfera política. Esta decisão consiste em definir quem participa do governo, ou seja, consiste em estabelecer quem tem o direito de debater e deliberar nos assuntos públicos. As duas visões de representação indicadas acima carregam dilemas insolúveis, pois acabam por excluir um grupo de pessoas das deliberações políticas: se os representantes devem agir conforme a instrução dos eleitores, suas opiniões deixam de ser publicamente relevantes. Eles se assemelhariam mais a advogados, que apenas representam o interesse de seus clientes e estão subordinados a eles. Neste primeiro caso, os representantes perdem a igualdade de falar e ser ouvido. Se, ao contrário, os representantes devem agir conforme seu juízo e se desvincular dos interesses de seus eleitores, são os votantes que abrem mão de influir no debate público e de deliberar. ${ }^{105}$ Neste segundo caso, os representantes se tornam o grupo que detém o privilégio de agir e discursar.

Nas palavras da autora,

"No primeiro caso, o governo se reduz a mera administração e a esfera pública desaparece; não há espaço para ver e ser visto em ação [...] No segundo caso, um pouco mais próximo da realidade, volta a se afirmar a velha distinção entre governantes e governados que a revolução pretendera abolir com o estabelecimento de uma república; aqui, mais uma vez, o povo não é admitido na esfera pública, mais uma vez o assunto do governo se torna privilégio de poucos [...]" (Sobre a Revolução, p. 300).

Segundo a autora, o governo pode se degenerar em administração quando os eleitores - por meio de lobbies e grupos de pressão - forçam os representantes a defender seus interesses no governo em detrimento dos interesses de outras pessoas. Aqui, não se trata de um interesse comum, pois ele pertence a indivíduos ou grupos particulares e não é formado por meio da persuasão e da deliberação em conjunto. Os lobbies e grupos de pressão não possuem qualidade política: eles não tratam das coisas do mundo, mas se ocupam do bem estar privado; eles não buscam o apoio geral do povo, mas visam a comandar e a coagir o representante a lhes favorecer. ${ }^{106}$

\footnotetext{
${ }^{105}$ Ver em Sobre a Revolução, p. 299.

${ }^{106}$ Sobre a diferença entre lobbies, grupos de pressão e as associações civis que são eminentemente políticas, ver em Democracy and the Politics of the Extraordinary, p. 289.
} 
Nesse contexto, mesmo que os representantes queiram representar o interesse do maior número de eleitores e promovam o bem estar pessoal da maioria, a liberdade de ação e o debate público são obliterados. Quando os representantes apenas cumprem instruções dadas por grupos de pressão, o debate público desaparece em favor da administração, uma vez que estas instruções não envolvem troca de opiniões e deliberação em conjunto.

Arendt indica também que, na Revolução Norte-Americana, a república passou a ser entendida como um governo representativo que tem como base a opinião do povo. Com isso, quando o representante não recebe indicações sobre como proceder, para melhor representar, ele deve imaginar o que fariam seus eleitores se tivessem a oportunidade de agir e, levando isso em consideração, atuar dentro das instâncias governamentais. Isso o tornaria um bom representante, mas, ainda assim, manteria a restrição da participação popular.

A autora enfatiza que a Constituição Norte-Americana foi provida de mecanismos para evitar que os representantes se tornassem uma minoria dominante, ou seja, alguns dispositivos constitucionais impedem que um grupo ocupe indefinidamente os cargos públicos e que governe de acordo com seu arbítrio. No entanto, isto não assegura a participação de todos os cidadãos. Dito de outra forma, o mecanismo de rotatividade de cargos e a delimitação do tempo do mandato dos representantes de maneira alguma possibilita que cada um tome parte nos assuntos públicos.

Conforme apontado anteriormente, apenas a institucionalização dos distritos e assembleias municipais poderia oferecer espaço para que cada cidadão participasse do debate público e das deliberações. Sem estes espaços de ação e liberdade, a Casa dos Representantes se torna o único lugar onde os homens podem estar entre pares para deliberar sobre os rumos do mundo comum. O povo, assim, fica restrito às atividades privadas e pode "afundar numa letargia" em que os indivíduos deixam de ter opinião sobre os assuntos de relevância pública. Pois, para a autora,

“As opiniões se formam em um processo de discussão aberta e debate público, e
onde não existe oportunidade de formar opiniões podem existir estados de
ânimo - ânimo das massas, ânimos dos indivíduos, este tão volúvel e
inconfiável quanto aquele -, mas não opinião" (Sobre a Revolução, p. 336.)

Nesta perspectiva, sem espaços onde cada um possa se inserir no debate público, a emergência de massas é sempre um risco. Quando muitas pessoas se encontram em uma 
letargia, o governo, longe de ter um poder que se assenta nas opiniões, tenta se sustentar por meio da medição do ânimo dos indivíduos e das massas. Neste caso, o governo é auxiliado por pesquisas de opinião que, apesar deste nome, não são capazes de identificar a pluralidade de opiniões pessoais, mas apenas medir os estados de ânimo. ${ }^{107}$

É importante enfatizar a atualidade da crítica de Arendt à concepção de representação que entende que os representantes estão subordinados aos eleitores. A autora percebeu que esta concepção, ao invés de efetivamente promover um governo apoiado em opiniões públicas, na verdade, deixa as instituições à mercê dos grupos de pressão e de lobbies.

Em 2014, o relatório da pesquisa intitulada "Testing Theories of American Politics: elites, interest groups, and average citizens" mostrou que as políticas públicas do governo dos EUA seguem os interesses das grandes corporações e raramente estão de acordo com a preferência dos eleitores. A pesquisa avaliou 1800 políticas públicas de 1981 a 2002, mediu a preferência dos eleitores por meio de pesquisas de opiniões e concluiu que os interesses econômicos determinam em grande medida as decisões legislativas e executivas. Nesse sentido, o relatório revela que a crítica de Arendt é pertinente na medida em que os representantes tendem a atender os interesses de grupos de pressão e de lobbies e que o estado de ânimo e as preferências dos eleitores dificilmente são capazes de influenciar o governo. $^{108}$

É importante lembrar que, para Arendt, os revolucionários do Novo Mundo criaram uma instituição dedicada à purificação das opiniões e interesses. Os senadores tinham originalmente como função expressar as diversas opiniões e interesses no país para, por meio do debate, decantá-los. ${ }^{109}$ Contudo, quando a vitalidade da vida pública se perdeu por falta de espaços institucionalizados de participação, a função do Senado foi deturpada. Os

\footnotetext{
${ }^{107}$ Como foi dito acima, sem debate público as opiniões não se formam. A mera aplicação de questionários de pesquisa de opinião não substitui o debate, pois os questionários são formados de perguntas que possuem um número limitado de respostas que, provavelmente, estão de acordo com algum estado de ânimo. Além disso, as pesquisas de opinião são ferramentas daquelas ciências do comportamento que foram tratadas acima. Seu objetivo consiste em estabelecer uma tendência com a interpretação de dados estatísticos.

${ }^{108}$ Conferir o relatório no site:

https://scholar.princeton.edu/sites/default/files/mgilens/files/gilens and page 2014 -

testing theories of american politics.doc.pdf Último acesso em 08/03/2016. Resumo desta pesquisa pode ser encontrado em www.telegraph.co.uk/news/worldnews/northamerica/usa/10769041/The-US-is-anoligarchy-study-concludes.html. Último acesso em 23/01/2016.

${ }^{109}$ Ver em Sobre a Revolução, p. 288.
} 
distritos e assembleias municipais proporcionavam a formação de diversas opiniões e o engajamento político, sem eles, não havia o que ser purificado no Senado, a não ser a opinião dos representantes. Em outras palavras, sem órgãos populares que proporcionem e resguardem o debate ampliado, as instâncias representativas se tornam os únicos espaços institucionais destinados à ação e deixam de purificar as opiniões do povo na medida em que tais opiniões não são expressas ou nem mesmo formadas.

Arendt indica, nesse sentido, que as duas concepções de representação, a inglesa e a norte-americana, trazem problemas para a ação popular, pois aquela proporciona a restrição do debate e da deliberação sobre os assuntos comuns e esta pode favorecer a administração na medida em que deixa os representantes expostos a grupos de pressão e lobbies.

Vimos anteriormente que, na Revolução Francesa, a questão da representação foi relacionada com a vontade geral da nação. De acordo com Sieyès, as sociedades populares, clubes e assembleias primárias expressavam vontades particulares. De modo diverso, a Assembleia Nacional seria capaz de representar uma vontade geral, una e indivisível. A operação de identificar povo com nação foi um dos fatores que contribuíram para que os órgãos populares fossem vistos como desimportantes ou mesmo dispensáveis, por proporcionarem a emergência de facções. O povo consiste em uma categoria política que engendra uma pluralidade de pessoas que para se articular precisa de laços e espaços públicos e para deliberar sobre os assuntos comuns precisa de uma pluralidade de instituições. A nação, ao contrário, é uma categoria natural, que prescinde de laços públicos e afirma a homogeneidade de uma comunidade baseada em um nascimento comum. Na medida em que a comunidade deixa de ser vista em sua pluralidade e é entendida como homogênea, uma única instituição basta para expressar tal uniformidade. Assim, a concepção de vontade geral da nação dispensa a participação ampliada e promove a representação. Embora a noção de representação que surgiu na França seja distinta das noções que haviam surgido na Inglaterra e na América do Norte, seu efeito foi semelhante: a redução do espaço de debate e a exclusão do povo dos assuntos públicos.

Diferentemente de Arendt, Manin interpreta estas três concepções de representação no mesmo sentido, todas elas expressariam em alguma medida o princípio de distinção. Como já foi exposto na introdução, para este autor, a noção de que os representantes são 
superiores aos representados em termos de virtudes e sabedoria ou em termos de estrato social e renda era o fundamento das leis eleitorais depois das revoluções na Inglaterra, nos EUA e na França. Apesar de esta noção ter sido defendida abertamente somente na Revolução Americana, regras que garantiam a distinção entre eleitos e eleitores foram instituídas a partir das Revoluções no Velho e no Novo Mundo.

$\mathrm{Na}$ Inglaterra, a lei de 1710 limitava o número de votantes e de candidatos às instâncias representativas por meio de exigência de um patamar de renda: a faixa de renda e o tamanho da propriedade exigidos para disputar eleições eram maiores do que os exigidos para votar. ${ }^{110} \mathrm{Na}$ França, mesmo com a instituição do voto universal masculino nas assembleias primárias em 1792, a restrição de renda foi mantida nas assembleias secundárias. Desta forma, a eleição indireta e a exigência de renda para os eleitores e eleitos de segundo estágio garantiam que os representantes pertenceriam aos estratos mais abastados da sociedade francesa. ${ }^{111} \mathrm{Na}$ América do Norte, não foi possível encontrar um critério de renda e de propriedade que pudesse ser comum a todos os estados em razão das diferenças econômicas entre eles. ${ }^{112}$

Nesse contexto, o princípio de distinção foi instituído por meio de arranjos eleitorais. De acordo com Manin, para os federalistas, as eleições devem proporcionar a escolha dos melhores. Na concepção federalista, os eleitos são diferentes dos eleitores: eles têm qualidades superiores, são mais sábios e virtuosos e, por isso, mais aptos a governar a favor do interesse do povo. ${ }^{113}$

Esta concepção de que os mais sábios e virtuosos devem governar consiste em uma visão elitista da política, em que uns possuem qualidades para ocupar os cargos públicos enquanto o restante do povo deve ficar restrito às atividades privadas. Para Arendt, esta concepção acaba por defender uma forma de governo oligárquica. ${ }^{114}$ A autora sugere que alguns teóricos defenderam esta concepção de governo elitista com base em uma constatação histórica. Eles perceberam que a atividade política, embora se refira a todos os membros de uma comunidade, quase sempre foi experimentada por um pequeno grupo,

\footnotetext{
${ }^{110}$ Ver em "O princípio da distinção", p. 188-191.

${ }^{111}$ Conferir em "O princípio da distinção", p. 192.

112 Ver em "O princípio da distinção", p. 198-199.

${ }^{113}$ Sobre a concepção federalista de distinção, conferir em "O princípio da distinção", p. 205, 210-213.

${ }^{114}$ Ver em Sobre a Revolução, p. 345.
} 
com isso, eles descartaram os raros momentos de participação ampliada e assumiram que o espaço de ação deve ser ocupado por poucas pessoas.

A autora argumenta que a qualidade política central de um cidadão consiste no desenvolvimento do gosto pela liberdade. Em outras palavras, os melhores na ação são aqueles que julgam que uma vida sem a participação nos assuntos comuns não é plenamente feliz. Nesta perspectiva, a sabedoria, o conhecimento técnico, o status social e a riqueza não garantem a boa condução dos negócios públicos, isto é, não são qualidades imprescindíveis para a ação. Levando isso em conta, Arendt conclui que a exclusão de alguém da política não deve ser determinada por teorias ou realizada por meio de dispositivos legais, mecanismos eleitorais ou institucionais. A exclusão da política deveria ser determinada apenas pela escolha de cada um, ou seja, deveria ser uma auto-exclusão: quem não se importa com os assuntos públicos tem o direito de não tomar parte neles. Ao contrário, quem desenvolve o gosto pela liberdade pública deveria ter o direito de debater e agir. $^{115}$

Com este argumento, mais uma vez, a autora indica que, com a derrota do sistema de conselhos, a exclusão da política deixa de ser a escolha de cada um e passa a ser determinada pela concepção de governo e representação que fundamentam a forma do corpo político e as leis. Ela ainda acrescenta que a falha em incorporar o sistema distrital na Constituição Norte-Americana, a perseguição e a destruição dos clubes e sociedades populares na França, dos sovietes na Rússia e dos conselhos revolucionários na Hungria fizeram com que a nova forma de representação que emergiu com o sistema de conselhos fosse negligenciada.

Como mencionado acima, o sistema de conselhos envolve a articulação de diversos órgãos e a formação de conselhos superiores onde delegados representam todos os participantes das instâncias locais e levam adiante o debate e as deliberações que nelas foram iniciadas. Nesse sentido, o sistema de conselhos também envolve eleição e representação. Mas de forma diferente do sistema partidário. Nos conselhos, as eleições envolvem auto-seleção: os eleitos são escolhidos entre pares, não são indicados de cima nem possuem necessariamente qualidades ou status social superiores. $\mathrm{O}$ que está em jogo na escolha de um representante para um conselho superior é o comprometimento com a

\footnotetext{
${ }^{115}$ Conferir em Sobre a Revolução, p. 349.
} 
questão que foi debatida e o compromisso mútuo de levar adiante tal questão. Nesta perspectiva, no sistema de conselhos, a representação envolve isonomia, a troca de opiniões, a deliberação comum e o virtuosismo da ação. Quem é eleito no sistema de conselhos demonstra dedicação ao mundo e mostra excelência para levar a cabo o empreendimento comum. Por estas razões, um delegado recebe o apoio dos demais.

Ao contrário, as concepções de representação inglesa, norte-americana e o princípio de distinção traçam previamente uma linha divisória entre quem deve governar e quem deve ser governado independentemente da questão que está em jogo no debate público.

Dessa maneira, vemos que a noção de representação se alterou historicamente: depois da Revolução Gloriosa foi promovida a noção de que os representantes deveriam agir de acordo com seu juízo e não ficar dependentes dos eleitores; na Revolução Americana surgiu a concepção de governo representativo em que o governo deve ser guiado pelo interesse e pelas instruções dadas pelos eleitores aos eleitos; na Revolução Francesa, por sua vez, a representação foi vinculada com a vontade geral da nação. Arendt identifica estas concepções de representação e aponta os seus problemas, principalmente, indica que elas negligenciaram a experiência de representação que surgiu no sistema de conselhos. A autora procura formular uma noção alternativa de representação que não imponha a exclusão da vida pública para a maioria dos membros de uma comunidade.

Kalyvas, em seu livro Democracy and the Politics of the Extraordinary, esclarece sobre a questão da representação no pensamento arendtiano. De acordo com ele, em uma primeira leitura, Arendt parece rejeitar qualquer concepção de representação. A definição da autora de liberdade como participação no governo dificilmente pode ser conciliada com a divisão funcional entre representantes e representados. Além disso, a ação política entendida como uma performance realizada diante de um público, que é semelhante a uma arte de execução, como tocar flauta ou dançar, não pode ser delegada ou representada por outros. Neste sentido, os feitos e discursos dos agentes não são representáveis. Ainda, o elogio ao sistema de conselhos pode ser interpretado como uma defesa da democracia direta. Levando isso em conta, muitos leitores interpretam que o pensamento de Arendt é definitivamente avesso a qualquer ideia de representação. ${ }^{116}$

${ }^{116}$ Ver em Democracy and the Politics of the Extraordinary, p. 272-274. 
Kalyvas sublinha que a autora não defende a forma de governo democrática. Ela apresenta quatro significados diferentes de democracia, todos eles trazem alguma dificuldade para o espaço político. O primeiro significado de democracia consiste na tirania da maioria, é uma forma de governo que suprime o dissenso da minoria. O segundo diz respeito à equalização social, consiste na tentativa de usar a política como instrumento de acabar com as desigualdades sociais. Já o terceiro é o governo da opinião pública unânime, em que a homogeneidade é criada com a imposição de apenas uma perspectiva. Por fim, o quarto é baseado na experiência da polis ateniense e consiste numa forma política de grande participação e de ampla liberdade, mas que resiste à estabilização e a constitucionalização da ação. Ao considerar estes significados de democracia, Arendt afirma que os três primeiros são hostis à pluralidade própria da política, acabam por restringir o espaço público e instituem uma forma de dominação. Ao contrário, a democracia ateniense promoveu a ação espontânea em alto grau, contudo, careceu de estabilidade e durabilidade. ${ }^{117}$

Neste ponto, Kalyvas coloca uma questão: se, no pensamento da autora, tanto a democracia como a representação são criticadas, como é possível conceber o corpo político? Ele responde que, com uma leitura mais detida de Sobre a Revolução, é possível identificar dois momentos em que a ação e a representação são articuladas: no trecho em que Arendt mostra a articulação e a coordenação de conselhos populares em forma de pirâmide para criar conselhos superiores, e no trecho em que ela indica a função do Senado Norte-Americano.

O sistema de conselhos criou uma nova forma de representação baseada na ação, no debate entre pares e na confiança entre iguais. Esta experiência política fundamentou a concepção de representação arendtiana. O comentador nota que tal concepção, no entanto, carece de alguns esclarecimentos. Por exemplo, a dificuldade de equacionar liberdade pública e representação permanece na medida em que os representantes dos conselhos de nível mais elevado parecem experimentar mais liberdade do que os participantes do conselho mais na base da pirâmide. Ainda, os mecanismos que poderiam garantir que as deliberações do conselho superior não fossem incompatíveis com os debates e as ações dos conselhos locais não são tratados no livro Sobre a Revolução. Também não fica claro

${ }^{117}$ Conferir em Democracy and the Politics of the Extraordinary, p. 265-266. 
como poderiam ser resolvidos conflitos entre representantes e representados. Nesse sentido, para ele, Arendt não desenvolve suficientemente seu próprio estudo sobre conselhos a ponto de esclarecer sobre os procedimentos de coordenação dos órgãos populares e como se daria o processo de decisão. ${ }^{118}$ Neste ponto Kalyvas parece concordar com Hobsbawn. Este historiador também entende que os conselhos consistem na verdadeira tradição revolucionária, em uma nova forma política. Mas critica Arendt ao afirmar que sua reflexão seria mais sólida se ela tivesse desenvolvido um estudo histórico detalhado de tais instituições. ${ }^{119}$

Por outro lado, para Kalyvas, a autora aponta com clareza a função das instâncias representativas ao tratar da criação do Senado na América do Norte. Ela sustenta que a representação é capaz de filtrar e refinar as opiniões públicas e os interesses de grupos. Em sua perspectiva, os espaços onde o povo pode formar e manifestar suas opiniões devem ser resguardados e, além disso, uma instituição deve ser destinada para considerar e refinar tais opiniões.

Kalyvas conclui que Arendt não é hostil à noção de representação, apenas ambivalente. Ele esclarece que a crítica da autora não mira a representação enquanto tal, mas se destina a atingir o princípio de governo representativo liberal que está preocupado com a felicidade privada e impede o povo de compartilhar a felicidade pública. Em outras palavras, Arendt procura uma noção de representação que possa ser combinada com a ação, que não restrinja o espaço público nem favoreça a administração. Esta noção foi encontrada no sistema de conselhos, uma vez que os membros de um conselho, depois de escolher alguém para lhes representar, não abandonam a atividade política, continuam a debater e deliberar. O sistema de conselhos, portanto, não divide os cidadãos entre governantes e governados, nem restringe o envolvimento do povo no governo ao dia das eleições. A finalidade última destes órgãos não consiste na escolha de representantes, mas primordialmente na ação e no debate público. ${ }^{120}$

Waldron, por sua vez, enfatiza a ação nas instâncias representativas e interpreta o elogio da autora à criação do Senado Norte-Americano basicamente como defesa do

\footnotetext{
${ }^{118}$ Ver em Democracy and the Politics of the Extraordinary, p. 280-281.

${ }^{119}$ Ver em Hobsbawn, Revolucionários, p. 205-206.

${ }^{120}$ Conferir em Democracy and the Politics of the Extraordinary, p. 282.
} 
governo representativo liberal e do sistema bipartidário. De acordo com ele, Arendt não desenvolve uma reflexão sobre arranjos eleitorais, mas indica três estruturas políticas imprescindíveis: representação, partidos e federalismo. ${ }^{121}$ No entanto, o autor não deixa claro qual a concepção de representação defendida por Arendt. Ele não aborda o debate sobre as diferentes formas representativas que emergiram na Inglaterra e na América do Norte nem relaciona federalismo e representação com sistema de conselhos. No que concerne este assunto, Waldron acaba por obscurecer ao invés de esclarecer as estruturas políticas tratadas por Arendt. Além disso, o autor desconsidera a crítica ao sistema partidário desenvolvida pela autora. Vimos que, segundo Arendt, os partidos não são órgãos populares, ao contrário, afastam o povo dos assuntos públicos e desfavorecem a ação política ao defenderem a execução de um programa partidário.

Wellmer também parece enfatizar o papel das instâncias de governo centrais. Para ele, os órgãos de participação locais são mais propícios a defender interesses particulares. As instâncias centrais seriam as responsáveis por evitar que os interesses privados se sobreponham aos interesses públicos. ${ }^{122}$ No entanto, entendemos que Arendt mostra por meio de sua concepção de representação algo diferente: as instâncias locais combinadas com instâncias representativas são capazes de refinar opiniões e interesses de forma que os interesses particulares podem ser combatidos na medida em que o povo não cai na letargia e pode formar opiniões publicamente.

Ainda, Kalyvas indica que o problema é oposto ao apontado por Wellmer: afirma que a autora não trata detidamente como se dariam as deliberações e como os conselhos locais poderiam acompanhar os debates nos conselhos superiores e cuidar para que tais deliberações visassem o bem público e não se desviassem com questões privadas. Nessa perspectiva, a autora indica que é mais provável que interesses privados desviem o governo onde a participação no espaço público é menor. Segundo Kalyvas, a única indicação da autora para evitar esse risco é no sentido de combinar o sistema de conselhos e a revisão judicial com o objetivo de resguardar a constituição e equilibrar o corpo político para que nem a maioria nem uma minoria passem a dominar. ${ }^{123}$

\footnotetext{
${ }^{121}$ Ver em "Arendt's constitutional politics", p. 210 e 211.

${ }^{122}$ Conferir em "Arendt on revolution", p. 230.

${ }^{123}$ Ver em Democracy and the Politics of the Extraordinary, p. 272.
} 
Levando isso em conta, concordamos com Correia quando ele afirma que o antagonismo entre representação e participação é falso. ${ }^{124}$ Arendt critica as concepções de representação que afastam a maioria dos cidadãos dos assuntos públicos e que reduzem o espaço público. Ela defende a existência de diversos centros de poderes, de diversos espaços constitucionais que são capazes de combinar participação e representação, durabilidade e mudança, novidade e estabilidade.

\subsection{História dos conceitos e o tesouro perdido das revoluções: algumas considerações}

Arendt dedica o último capítulo da obra Sobre a Revolução especialmente ao sistema de conselhos. Seu surgimento em diversos levantes revolucionários tem profunda ligação com o novo significado de fundação, de constituição, de governo e de representação.

Fundação, para a autora, a partir das revoluções passou a consistir na ação de um povo que estabelece um novo corpo político para si e, com isso, rompe com o regime precedente e inaugura uma nova era. $\mathrm{O}$ ato fundador visa ao início de uma nova forma de organização política que deve ser duradoura e também resguardar o espírito de liberdade que marcou seu início. Conforme Kalyvas ressalta, a institucionalização do sistema de conselhos permite salvar o espírito revolucionário e aumentar a fundação. ${ }^{125}$ Estes órgãos dão espaço para a ação do povo, para que cada um tome parte nos negócios públicos e permitem que cada geração possa refundar e reconstituir a república de acordo com suas opiniões, contexto e singularidade. Nesse sentido, o sistema de conselhos é capaz de articular fundação e refundação, estabilidade, permanência, mudança e novidade. ${ }^{126}$

A constituição de um novo corpo político nas revoluções começou por meio do surgimento e da articulação de órgãos populares, isto é, se deu por meio da participação ampliada, do debate que fez surgir um princípio compartilhado que articulou as pessoas publicamente e as inspirou a agir. Os atos que dão início à constituição de um novo corpo político envolvem um poder extraordinário, fora de instituições e regras pré-estabelecidas,

\footnotetext{
${ }^{124}$ Conferir em Hannah Arendt e a Modernidade, p. 203.

${ }^{125}$ Ver em Democracy and the Politics of the Extraordinary, p. 255 e 256.

${ }^{126}$ Conferir em Democracy and the Politics of the Extraordinary, p. 277.
} 
mas visam a institucionalizar e estabilizar o poder revolucionário. Em outras palavras, o povo, ao gerar o poder extraordinário nas revoluções e ao experimentar a liberdade, procura registrar em uma Carta Constitucional instituições, direitos e normas que permitam que este poder se transforme em algo ordinário e regular e que promovam a liberdade pública. Nas palavras de Kalyvas:

“A constitucionalização do extraordinário e a transformação do poder constituinte em um governo constituído salvaguardam as conquistas do novo início, estabilizam o espaço da aparência e, principalmente, delineiam o âmbito político dentro do qual a liberdade regular e a contestação agonística podem se realizar seguramente". (Democracy and the Politics of the Extraordinary, $p$. 256). ${ }^{127}$

Constituição, no sentido revolucionário, não significa simplesmente a redação de uma Carta Constitucional que estabelece um governo limitado. Mas significa registrar e instituir uma forma de governo nova, sem precedentes na história, que surgiu com o debate público e a ação ampliada. Historicamente, a constituição nas revoluções começou com a convocação espontânea e popular de assembleias constituintes. Estas assembleias eram espaços que abrigavam o debate do povo acerca dos princípios que o novo corpo político deveria adotar. Os conselhos nos eventos revolucionários foram articulados e ganharam força na medida em que o debate constitucional crescia.

Conforme dissemos acima, a partir das experiências revolucionárias, Arendt define governo como poder organizado e institucionalizado. A finalidade do governo, neste contexto, é política. Seu objetivo consiste em promover a liberdade pública, possibilitar a deliberação sobre os assuntos comuns, organizar a convivência entre os membros de uma comunidade. O sistema de conselhos emergiu como uma nova forma de governo que, caso fosse institucionalizada, permitiria a participação de cada um na vida política, uma vez que ele não dividia as pessoas entre governantes e governados, não criava uma hierarquia entre o especialista e o leigo. Em outras palavras, estes órgãos permitiam a participação popular na medida em que não estabeleceram que um, por deter conhecimento, poderia ordenar, enquanto os outros deveriam apenas seguir ordens. Além disso, em razão de possibilitar a ação de uma pluralidade de agentes, o sistema de conselhos é a forma de governo moderna

\footnotetext{
${ }^{127}$ No original: "The constitutionalization of the extraordinary and the transformation of the constituent power into a constituted government safeguard the achievements of new beginnings, stabilize the realm of appearance, and, most importantly, delineate the scope of the political within which normal freedom and agonistic contestation can take place safely".
} 
que mais contrasta com a burocracia, que consiste no governo de ninguém, em que regras e técnicas determinam a vida de todos.

Com a emergência do sistema de conselhos surgiu uma nova concepção de representação, vinculada com a ação e com a ampliação do espaço público. A partir desta concepção, a cidadania não é reduzida ao dia das eleições, isto é, a participação do povo não se resume ao voto. Ainda, os representantes não seguem apenas as instruções dos eleitores e as instituições não ficam expostas à coação e à pressão de interesses privados, pois há espaço para a formação e refinamento de opiniões públicas. Nos conselhos, a ação e o debate persistem mesmo depois de escolhidos delegados para os conselhos superiores. O engajamento de uma pluralidade de agentes nos assuntos públicos, de acordo com Arendt, evita que os interesses privados se imponham sobre os públicos, que a letargia domine a maioria dos membros de uma comunidade e até mesmo que sentimentos de massa venham a surgir.

Na perspectiva da autora, o sistema de conselhos consiste em uma alternativa ao governo representativo liberal e à sociedade de massas. Na medida em que possibilitam os vínculos públicos entre membros de uma comunidade, os conselhos combatem o isolamento dos indivíduos e a formação de massas. Ainda, eles podem refrear a valorização do trabalho, do consumo e da administração ao oferecer espaço para a ação em conjunto. Levando isso em consideração, Arendt procura salvar do esquecimento o sistema de conselhos e suas potencialidades, já que ele não foi levado adiante nem pela tradição revolucionária nem pelo liberalismo.

Nos termos de Correia, o objetivo de Sobre a Revolução consiste em tratar do fracasso das revoluções em consolidar o espírito revolucionário que foi cristalizado no sistema de conselhos. ${ }^{128}$ Nas palavras do comentador:

"O espírito revolucionário, um tesouro a ser encontrado, conformou para ela [Arendt] a mais flagrante imagem moderna da liberdade, a unir, liberdade e começo, ruptura e fundação, o iniciar e o levar a cabo que caracteriza a ação em conjunto. Reaviva-se assim a promessa de que a liberdade possa ser restituída como uma experiência política e se afirme em oposição à prevalência de uma vida que não aspira redimir-se do aprisionamento ao âmbito da necessidade, ampliado pelo crescimento artificial ou não natural do natural que é também marca distintiva da era e do mundo modernos" (Correia, Hannah Arendt e a Modernidade, p. 209).

${ }^{128}$ Ver em Hannah Arendt e a Modernidade, p. 200 e 201. 
Em nossa perspectiva, Arendt, além de tratar dos novos sentidos de liberdade, fundação, constituição, governo e representação, também revela, por meio da história destes conceitos, os problemas do presente para pensar a política. Dito de outra forma, ela indica que as definições correntes no século XX dos conceitos mencionados acima mais obscurecem do que esclarecem os eventos do mundo. Conforme foi tratado, no pensamento contemporâneo, as concepções de fundação, de revolução e de constituição não são relacionadas. Revolução geralmente é tratada em termos sociais, fundação é entendida nos termos de fabricação, e constituição é concebida estritamente no sentido jurídico e técnico. Nesse contexto, o sentido político destes conceitos é obliterado.

De acordo com a autora, a tradição revolucionária de inspiração marxista confere pouca importância aos aspectos políticos das revoluções e centra sua reflexão na transformação social. Desse modo, os conceitos de constituição e representação não são profundamente discutidos por esta tradição. Já a tradição liberal se atém aos conceitos de constituição, governo e representação com o objetivo de tratar de uma forma de governo que favoreça as atividades privadas e o bem estar individual. Desse modo, embora o liberalismo se ocupe com questões institucionais, não visa a promover a atividade política. Tanto a tradição revolucionária quanto a liberal entendem que a política é um meio para atingir um fim não político.

Arendt, ao recuperar a história do termo fundação, retoma também seu sentido político. A concepção romana de fundação vinculava o início da cidade com os grandes feitos dos cidadãos de várias gerações. $\mathrm{O}$ ato inicial era rememorado e aumentado pelos agentes. $\mathrm{Na}$ interpretação arendtiana, as concepções de Cícero e de Maquiavel, por um lado, auxiliam a pensar a fundação por relacionarem o ato de fundar com a abertura do espaço público, com a criação de leis, de instituições e de princípios de ação. Ainda, os dois autores tratam da permanência e da mudança do corpo político. Por outro lado, quando ambos justificam a concentração da autoridade em uma só pessoa em situações de emergência, trazem dificuldades para a política. Segundo a autora, a partir destes pensadores, Robespierre defendeu que quem é virtuoso pode usar da violência e de medidas extraordinárias para fazer uma república.

Contudo, não foi apenas esta noção de fundação, entendida como fabricação, que surgiu nas revoluções. Arendt indica que, com a ação dentro dos órgãos populares, fundar 
passou a significar também o agir em conjunto para constituir um novo corpo político duradouro. Neste sentido, fundação associa novidade e permanência. No entanto, este outro significado de fundação não foi resguardado pelo pensamento político. De acordo com a autora, fundar em seu tempo significa fabricar, não consiste em agir.

De forma semelhante, a concepção de constituição no século $\mathrm{XX}$ foi esvaziada de seu sentido político, pois não foi relacionada com a ação popular, mas com tecnicalidades, isto é, com arranjos institucionais e questões legais. Conforme mencionamos, Arendt indica que o termo constituição deixou de ser entendido como ação de constituir um corpo político e passou a ser entendido somente como sinônimo de Carta Constitucional. Isso ocorreu quando, por um lado, a noção de revolução permanente ganhou força e, por outro, quando diversos levantes revolucionários foram contidos com a outorga de uma Carta Constitucional ao povo. Aqueles que defendem uma revolução permanente abandonam o esforço de institucionalizar o poder revolucionário e a vida política, nesse sentido, abandonam a tarefa de criar uma constituição. Já aqueles que defendem que uma Constituição deve ser feita por especialistas em questões jurídicas e arranjos institucionais visam a limitar o poder popular e estabelecer um governo limitado, que garante direitos individuais e restringe a participação ampliada no governo. Nos dois casos, constituição foi vinculada com contrarrevolução.

Levando isso em conta, Arendt retoma as experiências revolucionárias para indicar que os homens engajados em uma revolução debateram e agiram para constituir um novo corpo político, para institucionalizar o poder que surgiu da ação em conjunto. Em outras palavras, o sentido político de constituição pode ser recuperado ao olhar para as ações e debates dos revolucionários no início das revoluções.

Com relação ao conceito de governo, Arendt indica que, contemporaneamente, governar está mais associado a fazer e gerir uma sociedade, isto é, organizar o trabalho, o consumo e condicionar o comportamento dos homens. A partir da genealogia deste conceito, a autora mostra que desde o início da filosofia política há uma tentativa de escapar da acidentalidade da ação, de seus efeitos imprevisíveis e incalculáveis. Para tanto, foi formulada uma concepção de governo que divide os membros da comunidade política entre quem dá ordens e quem obedece, de forma que o desenrolar da ação esteja de acordo com a ideia do iniciador. 
Apesar desta noção de governo ter perpassado toda a tradição filosófica, ela não tinha sido aplicada à vida política até a Modernidade, quando a ascensão da mentalidade do homo faber e a glorificação da violência promoveram a noção de que o ato de um governante deve seguir os moldes da fabricação. Em outras palavras, na Modernidade, os governantes puderam tentar moldar a comunidade política conforme sua ideia, usando quaisquer instrumentos e meios. Nesse contexto, a ditadura apareceu como a forma de governo mais conveniente. Com a ascensão da mentalidade do animal laborans, a vida e a atividade do trabalho se tornaram as principais preocupações públicas e a administração passou a ser relacionada com o governo. Arendt afirma que assim emergiu a burocracia, que consiste no governo de ninguém, pois não é influenciada por qualidades pessoais e opiniões públicas: as instituições funcionam conforme regras e procedimentos universais, que são determinados pela economia e pelas ciências do comportamento.

Contra a concepção de governo tradicional e as concepções modernas, a autora recupera a forma de governo que surgiu nas revoluções: o sistema de conselhos. Sua finalidade consistia em promover o debate e a ação, em garantir espaço para que cada um que prezasse a liberdade e escolhesse participar do governo pudesse deliberar nos assuntos comuns. Nesse sentido, o sistema de conselhos visa a resguardar a atividade política, tanto a ação institucional quanto as formas não institucionais e temporárias de ação.

Com relação à concepção de representação corrente no século XX, Arendt indica que ela está fundamentalmente relacionada ao princípio representativo liberal que entende a liberdade como atributo do indivíduo e, portanto, como algo a ser desfrutado no espaço privado. Os representantes, nessa perspectiva, supostamente formam uma elite que tem o papel de defender o bem estar individual e o interesse da maioria. Para Arendt, esta concepção reduz o espaço público, desvaloriza a ação e pode levar à apatia do povo. A interpretação de Manin sobre as revoluções e seu princípio de distinção perecem reforçar esta noção de representação.

A autora, contudo, mostra que o conceito de representação se alterou historicamente. Como foi mencionado, na Inglaterra, surgiu a noção de que os representantes deveriam ser independentes dos eleitores. Na Revolução Norte-Americana, por sua vez, a representação foi vinculada com o interesse privado dos eleitores: os representantes deveriam agir de acordo com as instruções dadas pelos representados, mas, 
na prática, as instâncias públicas acabavam seguindo as recomendações de grupos de pressão. Já na Revolução Francesa, o que deveria guiar os governantes era a vontade geral da nação. A nação, por ser homogênea, tinha uma vontade identificável e que deveria ser representada pela Assembleia Nacional.

Segundo Arendt, na concepção inglesa, a atividade política se torna privilégio de poucos, enquanto que na concepção norte-americana as instituições e governantes ficam à mercê de grupos de pressão e de lobbies, uma vez que, sem espaços públicos para a formação de opiniões públicas, só resta a disputa de força entre interesses privados. A concepção francesa, ao contrário, procura suprimir os interesses privados e as opiniões particulares ao buscar uma vontade una e indivisível. Com isso, o espaço de debate é reduzido em favor da unanimidade. Estas três concepções de representação definem, previamente, quem tem o direito de participar nos assuntos públicos e quem está excluído da política. Nesse sentido, o engajamento na ação e no debate público não depende da escolha de cada um, é delineado, antes, pela noção de representação.

Entretanto, Arendt encontra na experiência dos conselhos revolucionários uma concepção de representação que deixa o espaço público aberto à participação ampliada. Como já foi ressaltado acima, os conselhos são primordialmente órgãos de ação e debate. As eleições de representantes no sistema de conselhos não consistem na principal atividade popular, mas em uma pequena parte da atividade política. Além disso, as eleições se dão entre pares, são baseadas na isonomia e na confiança mútua.

Levando isso em conta, a história dos conceitos é capaz de apontar como as definições contemporâneas de fundação, constituição, governo e representação surgiram e se tornaram hegemônicas, e também é capaz de recuperar experiências políticas e concepções não veiculadas pela tradição, pela teoria revolucionária e pelo liberalismo. Arendt, ao chamar atenção para o deslocamento e a mudança de significado dos conceitos ao longo da história, torna mais evidente tanto o tesouro perdido das revoluções quanto as concepções teóricas contemporâneas que desvalorizam a atividade política. 


\section{Considerações finais}

Em Sobre a Revolução, um dos principais objetivos de Hannah Arendt consiste em recuperar e discutir as experiências e concepções políticas revolucionárias que foram esquecidas. Segundo a autora, a falta de memória gera a falta de compreensão. ${ }^{1}$ Em suas palavras:

"Pois se é verdade que todo o pensamento se inicia pela lembrança, também é verdade que nenhuma lembrança está a salvo a menos que se condense e se destile em um quadro de noções conceituais em que ela pode se exercer ainda mais. As experiências e mesmo as histórias do que são e do que sofrem os homens, dos acasos e acontecimentos, recaem na futilidade intrínseca da palavra viva e do gesto vivo, ao menos que sejam comentadas constantemente" (Sobre a Revolução, p. 280).

Em Entre o Passado e o Futuro, Arendt já havia afirmado a relação entre a memória e a reflexão sobre eventos políticos: “[...] memória, que é apenas um dos modos de pensamento, embora dos mais importantes, é impotente fora de um quadro de referências preestabelecido, e somente em raríssimas ocasiões a mente humana é capaz de reter algo inteiramente desconexo" (Entre o Passado e o Futuro, p. 31).

Como vimos, a compreensão diz respeito ao pensamento político e à ação. Compreender consiste em usar o próprio entendimento para buscar o significado de um evento, ou seja, consiste em entender o que se passou e o que se passa no mundo e em alcançar o sentido dos atos passados para que se possa agir no presente. A memória, como modo de pensamento, tem um papel na compreensão. Para lembrar e refletir sobre algo é preciso se apoiar em referências conceituais. Nesse sentido, em Sobre a Revolução, Arendt busca recuperar concepções e experiências esquecidas e relacioná-las em um quadro conceitual para contribuir com a tarefa da compreensão de seu tempo.

\footnotetext{
${ }^{1}$ Ver em Sobre a Revolução, p. 276.
} 
A autora faz isso por meio da narrativa da história dos conceitos: ao relacionar a genealogia e a mudança de significado dos termos revolução, liberdade, libertação, história, autoridade, resistência, fundação, constituição, governo e representação ao longo do tempo, ela indica as diferenças entre os horizontes de compreensão política da Antiguidade, da tradição, dos revolucionários e dos teóricos do século XIX e XX. Com isso, a história dos conceitos é capaz de suscitar, essencialmente, reflexões em quatro sentidos. Em primeiro lugar, o contraste entre as concepções antigas e tradicionais e as concepções que surgiram nos eventos revolucionários revela o pathos de novidade das revoluções e as especificidades da política na Modernidade. Em segundo, as concepções dos revolucionários no Novo e no Velho Mundo são elementos centrais para se pensar o sentido e o decurso das Revoluções na América do Norte e na França. Em terceiro, as mudanças de significado de um conceito ao longo do tempo explicam o motivo pelo qual um conceito é amalgamado a outro e a razão pela qual um conceito se torna uma forma oca que não contribui com a compreensão do presente. Por fim, a história dos conceitos recupera concepções e experiências que foram esquecidas e podem auxiliar na reflexão do presente.

É importante ressaltar que, ao recuperar ideias e feitos esquecidos, Arendt faz do passado um novo estoque de experiências que contribui para a compreensão do presente e abre um novo horizonte para a ação.

Conforme foi exposto no primeiro capítulo desta tese, a crise e a ruptura da tradição geraram dificuldades para a memória e para o pensamento político. A tradição conduzia ao passado na medida em que indicava as experiências e concepções que deveriam ser valorizadas. Com a sua quebra, os atos, feitos e pensamentos do passado correm o risco de serem esquecidos. Além disso, as categorias tradicionais perderam sua capacidade de explicar adequadamente os eventos contemporâneos. Nesse contexto, para compreender o mundo, é preciso formular novos conceitos e novas narrativas que resguardem os grandes atos e feitos do esquecimento.

De acordo com Arendt, a Revolução Norte-Americana foi esquecida e deixou de ter influência na vida política do século XIX e XX. O interesse pela teoria e pelo pensamento político na América do Norte desapareceu paulatinamente depois de estabelecida a Constituição da União. Assim, no Novo Mundo este evento revolucionário não foi 
debatido suficientemente para que fosse resguardado do esquecimento. Conforme ela sustenta, a memória e o pensamento precisam de conceitos para operar. Quando, nos EUA, as experiências políticas vividas deixaram de ser discutidas e lembradas, renunciou-se à formulação de sentido para tais experiências. De forma diversa, na Europa, o grande interesse pelo pensamento político fez com que a Revolução Francesa fosse discutida imensamente e dela fossem extraídas interpretações e teorias. Isso resguardou este evento do esquecimento e o tornou influente na vida política. ${ }^{2}$

Segundo Arendt, a Revolução Francesa em seu tempo era tratada de três maneiras distintas: por meio de categorias tradicionais, ou em termos marxistas, ou ainda pela perspectiva liberal. A autora critica estas três interpretações. As categorias tradicionais classificam a revolução como uma rebelião que evolve a guerra e a mudança de governo. Com isso, não revelam a forma específica de violência que surgiu nos ventos revolucionários, e outras novidades políticas. Em especial, a mudança das concepções de libertação e de liberdade, que passaram a indicar que os dominados, que antes estavam excluídos do espaço público, podiam participar das deliberações comuns com o objetivo de fundar um novo corpo político. Já a analise marxista, ao interpretar que a política está subordinada à economia, confere centralidade à transformação social e oblitera questões políticas nos eventos revolucionários. Ainda, esta análise descarta a espontaneidade da ação e a contingência da vida política - seus riscos e potencialidades a partir da Modernidade - ao mobilizar a filosofia da história para explicar os eventos revolucionários. O liberalismo, por outro lado, por vezes adota a concepção de progresso e entende que a última fase da Revolução Francesa consistiu em seu auge, por ter promovido a economia e a burguesia. Nesse sentido, a teoria liberal aceita acriticamente a promoção do trabalho e do consumo, entende que a ampliação das formas de felicidade privada é fruto do progresso e, por isso, os homens deveriam se dedicar às atividades privadas. Com isso, o liberalismo desestimula a participação nos assuntos públicos e, no que se refere à política, defende o governo limitado e o direito de voto, nessa medida, destaca as declarações de direitos principalmente no que concerne a garantia dos direitos individuais.

Para Arendt, nos anos de 1950 e 1960, o debate sobre concepções políticas que surgiram ou foram ressignificadas nas revoluções - tais como liberdade pública, poder,

\footnotetext{
${ }^{2}$ Conferir em Sobre a Revolução, p. 283.
} 
autoridade, fundação, direito de dissidência e sistema de conselhos - foi negligenciado, pois as categorias tradicionais não eram capazes nem sequer de definir o conceito de revolução, já o marxismo e o liberalismo não discutiam profundamente tais conceitos políticos.

Levando em conta o esquecimento da Revolução Norte-Americana e os problemas das interpretações da Revolução Francesa, Arendt entende que é preciso formular uma nova narrativa dos eventos revolucionários. Antes de apresentar sua narrativa, porém, ela indica quais categorias e procedimentos dificultam a compreensão da revolução.

A autora questiona os conceitos de história que não contribuem para tratar dos eventos revolucionários. Os regimes totalitários e os massacres promovidos pelo desenvolvimento de armas de destruição em massa colocaram em xeque a concepção de progresso da humanidade e abalaram a filosofia da história. No início do século XX, ficou evidente que o fim ou o telos da história que havia sido previsto não século anterior não se concretizou, além disso, a ideologia totalitária, ao se apoiar na concepção de movimento da história, também contribuiu para o declínio da filosofia da história. Diante disto, a autora descarta duas interpretações da Revolução Francesa: aquela que toma o período napoleônico como o momento de estruturação de uma sociedade e forma de governo mais evoluídas, e aquela que entende a revolução como necessária, resultante de forças históricas que são explicadas, fundamentalmente, por questões sociais e econômicas.

Ainda no primeiro capítulo, vimos que Arendt, ao dialogar com a tradição, o marxismo e o liberalismo, indica a insuficiência de certas categorias e desvela algumas características do conceito de revolução. Vale lembrar que, ao distinguir guerra de revolução, ela analisa o papel da violência nos eventos revolucionários e a íntima relação entre poder, novidade e revolução. Ao diferenciar rebelião e revolução, ela mostra que governo limitado e direitos civis não garantem a liberdade, que se concretiza somente na ação, com a participação nos assuntos públicos.

Contudo, indicar a insuficiência de certos conceitos e questionar os procedimentos da tradição filosófica, marxista e liberal consiste nos primeiros passos para apresentar o significado do conceito de revolução. Seu significado completo é revelado por meio de sua história. Como já foi mencionado, o termo revolução em sua origem dizia respeito à rotação dos astros. Quando foi usado para tratar de questões políticas pela primeira vez se 
referiu ao ciclo das formas constitucionais conhecidas. No século XVII, na Inglaterra, o termo foi aplicado para designar um levante que visava ao retorno a uma antiga forma constitucional. Somente no século XVIII, a partir dos eventos na América do Norte e na França, revolução passou a significar o rompimento com a forma de governo precedente para fundar um corpo político novo que promovesse a liberdade pública. A partir do século XIX, contudo, a conotação política do termo revolução perdeu força e o termo passou a ser mais relacionado com o movimento da história e com a transformação social.

Na perspectiva arendtiana, no contexto de ruptura com a tradição, de emergência da filosofia da história e da concepção moderna de história, a linguagem se tornou a melhor maneira de recuperar o passado. As palavras guardam conexão com o passado, por meio delas é possível identificar o fenômeno que as fez surgir e seu significado original. Além disso, por meio delas também é possível descobrir as mudanças de significado sofridas ao longo do tempo e os eventos que produziram tais mudanças.

Levando isso em consideração, pode-se sustentar que a história do conceito de revolução explica a concepção de política antiga, as concepções que sugiram durante as revoluções e foram esquecidas e aquelas que fundamentam as teorias políticas do século $\mathrm{XX}$. Com isso, a autora identifica os principais momentos políticos do passado, o peso dos eventos revolucionários na Modernidade e quais concepções teóricas trazem problemas para a compreensão do presente. De acordo com ela:

"Pois não é absolutamente insignificante que nosso vocabulário político ou remonte à Antiguidade clássica, grega e romana, ou possa ser rastreado inequivocamente até as revoluções setecentistas. Em outras palavras, se há algo de moderno em nossa terminologia política, é de origem revolucionária”. (Sobre a Revolução, p. 283).

As revoluções são eventos-chave para o pensamento político, elas inauguraram as concepções políticas modernas e, portanto, é fundamental discutir os novos termos e as mudanças de significados em termos antigos que os eventos revolucionários promoveram.

Nesse sentido, a história conceitual não trata apenas de um, mas relaciona diversos conceitos. A ressignificação do termo revolução engendra também a mudança de significado de outros conceitos, tais como liberdade, libertação, fundação, entre outros. Com os eventos revolucionários, a libertação, que antes se relacionava com o fim do domínio arbitrário de um governante ou de um senhor, passou a dizer respeito ao fim das 
restrições de acesso ao espaço público. A liberdade também teve seu sentido ampliado. $\mathrm{Na}$ Antiguidade, liberdade estava ligada à isonomia, à participação nos assuntos públicos. Com as revoluções, liberdade passou a significar também novo início: ficou evidente, a partir de então, que a ação humana tem a potência de interromper o curso da história para estabelecer uma nova época.

Arendt, depois de limpar o terreno, isto é, indicar as teorias, os conceitos de história e as categorias que são insuficientes para tratar dos eventos revolucionários, e depois também de apresentar suas definições de revolução, liberdade e libertação, tece as narrativas das duas revoluções do século XVIII. Estas narrativas são construídas, principalmente, por meio da história conceitual.

A autora indica que as origens das revoluções foram a crise da autoridade e o gosto pela liberdade pública. Como foi tratado no segundo capítulo desta tese, com a secularização, as monarquias na Europa perderam a sanção religiosa. Ao mesmo tempo, a leitura sobre os feitos e as experiências políticas dos antigos promoveu o gosto pela liberdade pública e a noção de que uma autoridade política poderia ser restabelecida por meio da ação. Para Arendt, isso levou os homens, nos dois lados do Atlântico, a debaterem sobre os assuntos públicos e a formularem queixas sobre os abusos do domínio da Coroa Inglesa na colônia norte-americana e da monarquia absoluta na França. Com o tempo, estas queixas, que visavam uma reforma do regime político, desencadearam ações de resistência que, por sua vez, provocaram a Declaração de Independência na América do Norte e a queda da monarquia na França.

Durante a luta contra o domínio arbitrário, os homens se tornaram cientes de que não era possível retornar a uma forma de governo precedente e que, para garantir a liberdade pública, era preciso constituir um novo corpo político. Para tanto, procuraram novos princípios e direitos para fundar uma nova forma de governo para si.

No Novo Mundo, os homens da revolução entenderam que o povo era plural e o poder emanava da associação entre diferentes pessoas e grupos. Além disso, defenderam que o poder e a autoridade não poderiam ser concentrados em somente um cargo público. Por isso, eles se empenharam em criar diversos centros de poder combinados de forma que um impedisse o outro de se tornar despótico. Conforme já foi mencionado, duas grandes inovações da Revolução Norte-Americana consistiram no estabelecimento de uma 
instituição dedicada ao julgamento e à autoridade e outra dedicada à pluralidade de opiniões: a Suprema Corte teve o papel de resguardar a Constituição, aconselhar e julgar os atos do governo e dos cidadãos para que estivessem de acordo com as leis e com os princípios fundamentais; já o Senado teve o papel de filtrar as diversas opiniões.

Nesse sentido, vimos que, institucionalmente falando, a principal novidade deste evento revolucionário dizia respeito à organização do poder da União, isto é, estava ligada às instituições centrais e à sua associação com as instituições estaduais. Os federalistas se ocuparam de estabelecer uma república representativa e de criar arranjos eleitorais para selecionar representantes. Eles não eram favoráveis a recorrer ao povo periodicamente ou em casos de emergência, por isso, não se ocuparam de criar instituições onde o povo pudesse debater e agir, nem de criar mecanismos constitucionais para consultas populares.

Com isso, a Constituição não institucionalizou as assembleias municipais e distritais, as associações que fizeram surgir a revolução. Como foi exposto, Jefferson foi o único dentre os pais fundadores a defender a institucionalização de espaços para a participação popular. Ele defendeu a criação de um sistema distrital, pois percebeu que, depois de estabelecida a Carta Constitucional, a participação experimentada no início da revolução foi perdida e o governo se tornou, novamente, privilégio de poucos.

Para Jefferson, um governo bem estabelecido deveria proporcionar a felicidade em seu sentido privado e público. Por um lado, deixar que os indivíduos desfrutem das liberdades privadas e do bem estar pessoal e, de outro, permitir a participação nos assuntos públicos. No entanto, o sentido público de felicidade foi esquecido. Isso contribuiu para que os direitos individuais se sobrepusessem à preocupação com a institucionalização dos espaços onde cada cidadão poderia tomar parte no poder. Assim, a América do Norte é mais lembrada por promover o bem estar pessoal por meio de direitos individuais e por meio da abundância de produção e consumo, do que pela promoção da felicidade pública.

Levando as principais concepções dos pais fundadores em conta, Arendt mostra o que levou os homens do Novo Mundo à ação e explica quais foram as novidades que surgiram com a fundação dos EUA e quais os problemas encontrados para se garantir a liberdade pública.

De forma semelhante, as concepções dos franceses também indicaram a origem e o curso da revolução, bem como as novidades e problemas que surgiram com a ação 
revolucionária na França. De acordo com a autora, os princípios defendidos no início da Revolução Francesa - liberdade, igualdade e fraternidade - foram desvirtuados paulatinamente conforme as noções de soberania e vontade geral da nação, defendidas por Sieyès, ganharam prestígio. Tais concepções são mais afeitas à centralização do poder e das decisões do que ao procedimento de debate público e deliberação em conjunto. Desse modo, a bandeira da liberdade pública foi enfraquecida. Além disso, a concepção de nação, associada à soberania e à vontade geral, deslocou a noção de igualdade do campo político para o biológico: a igualdade deixou de ser entendida em termos de direitos constituídos e de participação nos assuntos públicos e passou a ser relacionada à homogeneidade de uma população que tem um nascimento comum.

Com relação à fraternidade, a concepção de piedade entendida como a principal virtude pública, aparentemente se referia a esta bandeira. Na perspectiva de Robespierre, a fundação da república dependia da virtude do povo, assim, era imprescindível cultivar a piedade e perseguir todos os homens torpes para que a república não fosse corrompida. Neste contexto, a vigilância e a desconfiança entre os franceses foram promovidas e se iniciou a violenta caça aos hipócritas, que silenciou a livre troca de opiniões e condenou sumariamente milhares de revolucionários.

A noção de fundação como fazer, associada às concepções de soberania, vontade geral e piedade não permitiram a estabilidade das instituições e da participação política na França. Esta noção de fundação suscitou a centralização das decisões em uma só pessoa e legitimou o uso de medidas extraordinárias e de meios violentos por um longo período. Segundo Arendt, estas são as principais concepções que conduziram este evento revolucionário ao fracasso. Elas foram mobilizadas durante a Revolução Francesa na tentativa de responder ao desafio de instituir um novo corpo político, de colocar as leis acima dos homens e de libertar os homens da opressão causada pela miséria para que eles pudessem se dedicar à atividade política. Tais concepções, embora não tenham sido completamente bem sucedidas no que se refere à fundação de um corpo político duradouro e à constituição de uma nova autoridade política, indicam os riscos que a ação revolucionária envolve e os descaminhos da política na Modernidade.

As duas narrativas que a autora apresenta tratam do fracasso dos eventos revolucionários em instituir a liberdade pública. Na narrativa da Revolução Americana, a 
autora sustenta que, apesar de um corpo político duradouro ter sido fundado, a felicidade pública não foi resguardada e a participação ampliada no governo não foi institucionalizada. Já na Revolução Francesa, nenhuma Constituição foi duradoura e, em consequência disto, leis e instituições não foram criadas para preservar os princípios de liberdade, igualdade e fraternidade. Mesmo assim, Arendt entende que, politicamente, estes eventos são fundamentais, não só para refletir sobre as dificuldades da política e os riscos da ação, mas para recuperar o tesouro perdido das revoluções: os conselhos. As tradições liberal e marxista não salvaram do esquecimento a experiência política nos conselhos e os novos significados de conceitos como fundação, constituição, governo e representação. Nesse sentido, Arendt recupera a experiência nos conselhos revolucionários para refletir sobre a potencialidade da ação na Modernidade.

Os conselhos emergiram em diversos levantes revolucionários desde o século XVIII até o XX. Eles se constituíram como espaços públicos onde a liberdade poderia ser experimentada, pois cada cidadão podia, ao adentrar neles, tomar parte no poder. Eles criaram um modo de representação que não exclui a ação do povo. Além disso, de acordo com a autora, o sistema de conselhos permitia interligar a permanência e a novidade. Nas suas palavras,

\footnotetext{
"Nesta direção eu vejo a possibilidade de se formar um novo conceito de estado. Um estado-conselho deste tipo, para o qual o princípio de soberania fosse totalmente discrepante, seria admiravelmente ajustado às mais diversas espécies de federações, especialmente porque nele o poder seria constituído horizontalmente e não verticalmente. Mas se você me perguntar que probabilidade existe de ele ser realizado, então devo dizer: Muito pouca, se tanto. E ainda, quem sabe, apesar de tudo - no encalço da próxima revolução" (Crises da República, p. 201).
}

Arendt rememora a experiência política nos conselhos por dois motivos. Por um lado, os feitos dos revolucionários podem inspirar a ação na medida em que se extrai deles um quadro de referência conceitual. A partir da ação nos conselhos, a autora redefine os sentidos de fundação, constituição, governo e representação. Fundar, para ela, consiste em criar um novo corpo político que permita a participação ampliada nos assuntos públicos. Este ato não envolve somente instituições e leis, também possui uma dimensão simbólica, isto é, princípios compartilhados que inspiram ações futuras e conservam a vitalidade do corpo político. Constituição, por sua vez, significa o ato de um povo que, por meio do debate e da deliberação em conjunto, institui para si uma forma de governo e a registra 
numa Carta Constitucional. Já a noção de governo é definida como poder institucionalizado e, nessa medida, tem como objetivo promover a atividade política. Representação, de acordo com a autora, envolve a escolha de representantes entre pares e é baseada na confiança mútua. Ela se dá em espaços de debate público, nesse sentido, a representação não impede a ação do povo, ao contrário, depende dela.

Por outro lado, a reflexão sobre o surgimento do sistema de conselhos e sua derrota para o sistema de partidos é profícua para compreender a política a partir da Modernidade. Tal reflexão mostra como alguns conceitos foram esvaziados de seu sentido político na contemporaneidade. Indica o modo pelo qual a fundação foi entendida como 'fazer uma sociedade de alto a baixo', como o ato de constituir foi reduzido a um conjunto de mecanismos legais e tecnicalidades, o modo pelo qual governo passou a ser identificado com dominação legítima e como emergiu a forma de governo burocrática. Além disso, esta reflexão mostra como surgiram as concepções de representação avessas à participação: uma afirma que o representante é um mero administrador que defende os interesses particulares dos eleitores, outra atesta que a participação política do povo se restringe ao voto uma vez que o representante deve agir independentemente da opinião dos eleitores.

Conforme foi exposto no terceiro capítulo desta tese, a autora recupera o significado antigo de fundação e de governo e aponta as mudanças dos usos destes termos a partir das revoluções, os novos sentidos políticos que surgiram e os sentidos que foram esquecidos. Com relação aos conceitos de constituição e representação, a autora traça sua história a partir das revoluções. Ela trata tanto do significado destes termos que pode ser extraídos da experiência nos conselhos quanto das definições referentes ao liberalismo e à tradição revolucionária.

Ao apresentar a história destes conceitos, Arendt visa a criticar o presente - o governo representativo liberal, a burocracia, a substituição da ação pela administração - e a contribuir para a valorização da política.

Levando isso em conta, é possível notar que a história conceitual que a autora elabora em Sobre a Revolução não é cronologicamente orientada, ela não parte da origem dos conceitos, ao contrário, ela inicia sua análise com os dilemas do presente: indicando as categorias que são inadequadas para compreender o mundo. 
A autora escreve em um momento de crise, quando as categorias tradicionais e as teorias contemporâneas não oferecem mais respostas às questões ou até mesmo são inadequadas para formular as questões relevantes à contemporaneidade. Os termos-chave para o pensamento político parecem ter perdido seu significado, como, por exemplo, as noções de liberdade e felicidade, que foram relacionadas ao indivíduo e às atividades privadas; a concepção de constituição, que foi entendida como um simples termo técnicojurídico; a noção de igualdade, que foi reduzida à sua dimensão social. Outros conceitos se tornaram indistintos, como guerra e revolução, violência e poder, dominação e governo.

Arendt, depois de identificar os conceitos que foram mal compreendidos em seu tempo, procura suas origens e suas mudanças ao longo da história. De acordo com ela, a política é a atividade baseada na ação e no discurso, isto é, todo ato vem acompanhado de palavras que enunciam o que o agente pretende colocar em movimento. Posteriormente, o ato é lembrado por meio de narrativas que desvelam o sentido da ação. Nessa perspectiva, a investigação das concepções dos agentes e dos narradores das ações esclarece sobre as mudanças e permanências nos significados dos conceitos ao longo do tempo. Esta investigação revela o horizonte de compreensão dos agentes em um determinado evento e as interpretações sobre este evento. Nesse sentido, a história dos conceitos é capaz de indicar os significados que foram esquecidos e o modo pelo qual outros significados se tornaram proeminentes no pensamento contemporâneo.

Conforme indicamos na introdução desta tese, alguns comentadores, notadamente Benhabib, Young-Bruel, Correia e Duarte, desenvolvem reflexões sobre o procedimento arendtiano de busca da origem da palavra. Contudo, a literatura sobre o pensamento de Arendt não discute sobre as mudanças de significados dos conceitos ao longo do tempo. Em nossa perspectiva, três razões explicam a falta de comentários acerca da história dos conceitos. A primeira consiste no fato de que nem todos os conceitos são tratados historicamente na obra de Arendt. Por exemplo, os conceitos de poder e de violência não se modificaram da Antiguidade para a Modernidade, apenas as formas de organizar e institucionalizar o poder se alteraram com o tempo. De forma semelhante, foram os meios de violência e o lugar que a violência ocupou que mudaram durante a história. Entendemos que, embora a autora não mobilize a história conceitual para tratar de todos seus conceitos 
políticos, em Sobre a Revolução, a narrativa da história dos conceitos desempenha um papel central.

A segunda razão que explica a falta de discussão sobre o procedimento arendtiano de explorar a história dos conceitos está relacionada ao status de Sobre a Revolução. Conforme foi exposto antes, este livro foi considerado secundário dentro do pensamento da autora, assim, os conceitos e procedimentos mobilizados nele contam com poucos comentários. Por fim, a terceira razão diz respeito ao recorte de pesquisa da maior parte dos comentadores, que não privilegia os temas presentes em Sobre a Revolução e, com isso, a história conceitual não se tornou assunto privilegiado de debate. Nesse sentido, esperamos com esta tese haver contribuído com a literatura sobre o pensamento arendtiano ao discutirmos os temas relacionados à revolução e ao tratarmos da história dos conceitos.

É importante destacar que a história conceitual que a autora produz não aplica a concepção de história como juíza dos conceitos, não conta a história dos vencedores, pois não apresenta o uso do conceito atual sem criticá-lo. Ao contrário, a autora problematiza o uso de alguns conceitos em seu tempo, não toma a definição corrente como correta. Ela procura veicular os sentidos perdidos que podem apontar para outra forma de refletir sobre a política e o mundo.

Levando isso em consideração, vemos que o modo de proceder de Arendt e seus conceitos são capazes de questionar a revisão histórica e teórica das revoluções em nosso tempo. A crítica à Revolução Francesa que surgiu a partir dos anos de 1980 acaba por descartar as experiências políticas que emergiram neste evento. ${ }^{3}$ Além disso, a Constituição dos EUA - entendida como conjunto de mecanismos que estabeleceu um governo representativo liberal - passou a ser tomada como modelo, sem que a ação ampliada na Revolução Norte-Americana seja valorizada. De forma distinta, Arendt nos ensina que a Revolução Francesa, apesar de seu fracasso, indica os riscos e potencialidades da ação. A Revolução Norte-Americana, por sua vez, mostra que ser bem sucedido na tarefa de estabelecer uma Constituição duradoura não significa garantir a vitalidade da atividade política. Assim, consideramos que as reflexões presentes em Sobre a Revolução contribuem para a compreensão de nosso tempo.

\footnotetext{
${ }^{3}$ Especialmente a literatura que gira em torno do Dicionário crítico da Revolução Francesa, organizado por Furet e Ozouf.
} 


\section{Bibliografia}

\section{Bibliografia principal}

ARENDT, H. A condição humana. São Paulo: Forense Universitária, 2010. . A promessa da política. Rio de Janeiro: DIFEL, 2009. . A vida do Espírito. Rio de Janeiro: Relume Dumará, 1995. . Between Past and Future. New York: Viking Press, 1968.

. Eichmann em Jerusalém: um relato sobre a banalidade do mal. São Paulo: Companhia das Letras, 1999. Entre amigas: a correspondência de Hannah Arendt e Mary MacCarthy. Rio de Janeiro: Relume Dumará, 1995.

. Entre o Passado e o Futuro. São Paulo: Perspectiva, 2005. . Essay in Understanding. New York: Shcocken Books, 1994.

. Compreender formação, exílio e totalitarismo. São Paulo: Companhia das Letras, 2008. . Homens em tempos sombrios. São Paulo: Companhia das Letras, 1987. "Karl Marx and the Tradition of Western Political Thougut". Social Research. Charlotte, vol. 69, n², 2002. 
. Lições sobre a filosofia política de Kant. Rio de Janeiro: Relume-Dumará, 1994.

. On Revolution. New York: Penguin Books, 2006.

. On Violence. New York: Harcourt, Brace \& World, 1970.

. O que é política. Rio de Janeiro: Bertrand Brasil, 2007.

. Origens do Totalitarismo. São Paulo: Companhia da Letras, 1989.

. RahelVarnhagen: a vida de uma judia alemã na época do romantismo. Rio de Janeiro: Relume Dumará, 1994.

. Responsabilidade e julgamento. São Paulo: Companhia das Letras, 2003.

. Sobre a Revolução. São Paulo: Companhia das Letras, 2011.

. Sobre a Violência. Rio de Janeiro: Civilização Brasileira, 2010.

. The Human Condition. Chicago: The University of Chicago Press, 1958.

. "Totalitarian Imperialism: Reflections on The Hungarian Revolution". Em The Journal of Politics, vol. 20, nº 1, 1958.

. The Origins of Totalitarianism. New York: Harvest, 1979.

$\overline{\mathrm{n}^{\mathrm{o}} 7,2005}$.

. "Trabalho, obra e ação". In Cadernos de Ética e Filosofia Política. São Paulo,

. "Sobre Hannah Arendt”. Em Revista Inquietude. Goiania, vol. 1, nº 2, 2010.

2. Bibliografia de comentadores

ALMEIDA, V. Educação em Hannah Arendt: entre o mundo deserto e o amor ao mundo. São Paulo: Cortez, 2011.

ALVES NETO, R. "Crítica arendtiana à democracia liberal e o sentido político da liberdade”. In: Cadernos de Ética e Filosofia Política, n 23. São Paulo: julho, 2013.

ARATO, A. Civil Society, Constitution, and Legitimacy. New York: Rowman \& Littlefield Publishers, 2000.

BEINER, R. "Hannah Arendt - sobre 'O Julgar"'. In ARENDT, H. Lições sobre a filosofia política de Kant. Rio de Janeiro: Relume-Dumará, 1994.

BENHABIB, S. The reluctant modernism of Hannah Arendt. Thovsand Oaks, California: Sage Publications, 2003.

BERNSTEIN, R. Violence: Thinking without Banisters. Malden: Polity Press, 2013. 
BIGNOTTO, N. "Totalitarismo e liberdade no pensamento de Hannah Arendt". In MORAES, E. J. e BIGNOTTO, N. (orgs.). Hannah Arendt: diálogos, reflexões, memórias. Belo Horizonte: ed. UFMG, 2001.

de 2011.

. “Hannah Arendt e a revolução Francesa". In: O que nos faz pensar, n 29, maio

CORREIA, A. Hannah Arendt e a Modernidade: politica, economia e a disputa por uma fronteira. Rio de Janeiro: Forense Universitária, 2014.

. (org.). Transpondo o abismo: Arendt entre a filosofia e a política. Rio de Janeiro: Forense Universitária, 2002.

(org.). Hannah Arendt: entre o passado e o futuro. Juiz de Fora: UFJF, 2008.

DUARTE, A. O pensamento à sombra da ruptura. São Paulo: Paz e Terra, 2000.

"A dimensão política da filosofia kantiana segundo Hannah Arendt". In ARENDT, H. Lições sobre a filosofia política de Kant. Rio de Janeiro: Relume-Dumará, 1994.

- "Poder e Violência no Pensamento Político de Hannah Arendt: uma reconsideração". In ARENDT, H. Sobre a violência. Rio de Janeiro: Civilização Brasileira, 2010.

. Vidas em risco: crítica do presente em Heidegger, Arendt e Foucault. Rio de Janeiro: Forense Universitária, 2010.

JARDIM, E. Hannah Arendt: pensadora da crise e de um novo início. Rio de Janeiro: Civilização Brasileira, 2011.

HOBSBAWN, E. Revolucionários. Rio de Janeiro: Paz e Terra, 1985.

HONIG, B. "Declarations of Independence: Arendt and Derrida on the Problem of Founding a Republic". The American Political Science Review, vol. 58, nº 1, 1991.

KALYVAS, A. Democracy and the Politics of the Extraordinary: Max Webber, Carl Schmitt and Hannah Arendt. Cambridge: Cambridge University Press, 2009.

"From the act to decision: Hannah Arendt and the Question of Decisionism". Political Theory. Vol. 32, n³, jun. 2004.

KOHN, J. "Introdução à edição americana". In ARENDT, H. Responsabilidade e julgamento. São Paulo: Companhia das Letras, 2003.

LEBRUN, G. Passeios ao léu. São Paulo: Brasiliense, 1983.

LEFORT, C. "Hannah Arendt e a questão do político". In: Pensando o político: ensaios sobre democracia, revolução e liberdade. Rio de Janeiro: Paz e Terra, 1991.

MORAES, E. J. e BIGNOTTO, N. (orgs.). Hannah Arendt: diálogos, reflexões, memórias. Belo Horizonte: ed. UFMG, 2001.

MÜLLER, M. “Revoluções Americana e Francesa: luta por liberdade ou libertação?”. In: Cadernos de Ética e Filosofia Política, n 23. São Paulo: julho, 2013. 
OLIVEIRA, J. "Revolução como fundação no pensamento de Hannah Arendt". In: Cadernos de Ética e Filosofia Política, n 23. São Paulo: julho, 2013.

O'SULLIVAN, N. "Hannah Arendt: a nostalgia helênica e a sociedade industrial". In CRESPIGNY, A. Filosofia política contemporânea. Brasília: UNB, 1979.

TAMINIAUX, J. "Athens and Rome". In: VILLA, D. The Cambridge Companion to Hannah Arendt. Cambridge: Cambridge University Press, 2000.

TELES, E. Pensar e agir: narrativa e política na filosofia de Hannah Arendt. Dissertação de mestrado. São Paulo: Departamento de Filosofia, USP, 2002.

WALDRON, J. In: VILLA, D. The Cambridge Companion to Hannah Arendt. Cambridge, 2000.

WELlMER, A. "Arendt ons Revolution". In: VILLA, D. The Cambridge Companion to Hannah Arendt. Cambridge, 2000.

YOUNG-BRUEHL, E. Hannah Arendt: por amor ao mundo. Rio de Janeiro: Relume Dumará, 1987.

\section{Bibliografia de apoio}

ARANOVICH, P. "O Riscontro: considerações sobre a política e a história em Maquiavel”. Em: Tempo e Ciência, vol. 20, n 40, 2013.

BAKER, M. "Constituição". Em FURET, F. e OZOUF, M. (orgs.). Dicionário Crítico da Revolução Francesa. Rio de Janeiro: Nova Fronteira, 1989.

. "Soberania". Em FURET, F. e OZOUF, M. (orgs.). Dicionário Crítico da Revolução Francesa. Rio de Janeiro: Nova Fronteira, 1989.

BARROS, A. Republicanismo inglês: uma teoria da liberdade. São Paulo: Discurso Editorial, 2015.

. “A Matriz Inglesa”. Em BIGNOTTO, N. (org). Matrizes do Republicanismo. Belo Horizonte: Editora UFMG, 2013.

BERNARDO, I. P. O De Republica de Cícero natureza, política e história. São Paulo: USP, Dissertação (mestrado), 2012.

BENJAMIN, W. "Sobre o conceito de história". In: Magia e técnica, arte e política. São Paulo: Brasiliense, 1985.

BIGNOTTO, N. Maquiavel Republicano. São Paulo: Loyola, 1991.

. "O círculo e a linha". In: NOVAES, A. (org.). Tempo e História. São Paulo: Companhia das Letras, 1992. 
Paulo: USP, 2003.

. "República dos antigos, república dos modernos". In: Revista da USP. São . Pensar a República. Belo Horizonte: UFMG, 2000.

. "A Matriz Francesa". Em BIGNOTTO, N. (org). Matrizes do Republicanismo.

Belo Horizonte: Editora UFMG, 2013.

CICERO, M. T. On Duty. Cambridge: Cambridge University Press, 2000.

. De Republica. Cambridge: Cambridge University Press, 1998.

CONSTANT, B. "Da liberdade dos antigos comparada à dos modernos". Cadernos de Ética e Filosofia Política. São Paulo, nº 1, 1999.

FURET, F. e OZOUF, M. (orgs.). Dicionário Crítico da Revolução Francesa. Rio de Janeiro: Nova Fronteira, 1989.

JEFFERSON, T. Letter Jefferson to Madison, 6 de setembro de 1789. Disponível em http://press-pubs.uchicago.edu;founders. Último acesso em 15 de dezembro de 2015.

GILENS, M. e PAGE, B. "Testing Theories of American Politics: elites, interest groups, and average citizens". Em Perspective on Politics, vol. 12, n 3, 2014.

GUENIFFEY, P. e HALÉVI, R. "Clubes e Sociedades Populares. Em FURET, F. e OZOUF, M. (orgs.). Dicionário Crítico da Revolução Francesa. Rio de Janeiro: Nova Fronteira, 1989.

HABERMAS, J. Direito e Democracia: entre a facticidade e validade II. Rio de Janeiro: Tempo Brasileiro, 2003.

HAMILTON, A.; JAY, J., MADISON, J. O Federalista. Brasília: Editora da UNB, 1984.

KOSELLECK, R. Futuro Passado. Rio de Janeiro: Contraponto - Ed. PUC-Rio, 2006.

MADISON, J. Letter Madison to Jefferson, 4 de fevereiro de 1790. Disponível em http://press-pubs.uchicago.edu;founders. Último acesso em 15 de dezembro de 2015.

MANIN. B. "O princípio da distinção". Revista Brasileira de Ciência Política. Brasília, no 4 , ano 2010.

MAQUIAVEL, N. Discursos sobre a primeira década de Tito Lívio. São Paulo: Martins Fontes: 2007.

. O Príncipe. São Paulo: Martins Fontes: 2010.

MARX, K. "O 18 Brumário de Luís Bonaparte". Em FERNANDES, F. (org.). Karl Marx e Friedrich Engels: história. São Paulo: Ática, 2003.

MICHELET, J. História da Revolução Francesa: da queda da Bastilha a festa da Federação. São Paulo: Companhia das Letras, 1989.

MOMIGLIANO, A. As raizes clássicas da historiografia moderna. Bauru: Edusc, 2004.

PALTI, E. "From the Ideas to Concepts to Metaphors: the German Tradition of Intelectual History and the Complex Fabric of Language". Em History and Theory, n 49, 2010. 
PRADO. Anna Lia do A. A. In: TUCIDIDES. História da Guerra do Peloponeso. Livro I. São Paulo: Martins Fontes, 2008.

QUIRINO, C N G. Dos infortúnios da igualdade ao gozo da liberdade. São Paulo: Discurso Editorial, 2001.

RAAFLAUB, K. The discovery of freedom in Ancient Greece. Chicago: Chicago University Prees, 2004.

ROMILLY Les usages de la liberté. Éditions de la Baconnière, 1990.

SAlUSTIO. A Guerra de Jugurta. Petrópolis: Vozes, Coleção Clássicos do Pensamento Político, 1997.

STARLING, H. “A Matriz Norte-Americana". Em BIGNOTTO (org.). Matrizes do Republicanismo. Belo Horizonte: Editora UFMG, 2013.

TELES, Edson. "Direitos Humanos, governança e democracia”. Em Ideias, no 4, 2012.

TITO, L. História de Roma. São Paulo: Paumape, 1989.

TOCQUEVILLE, A. O Antigo Regime e a Revolução. Brasília: UNB, 1997. . A democracia na América. São Paulo: Martins Fontes, 2005.

TUCIDIDES. História da Guerra do Peloponeso. Brasília: UNB, 2001. 